\title{
History of the Physiological Society during its First Fifty Years 1876-1926
}

BY

SIR EDWARD SHARPEY-SCHAFER, F.R.S.

Issued by the Society and published as a

Supplement to the Journal of Physiology

December, 1927

CAMBRIDGE UNIVERSITY PRESS

LONDON: FETTER LANE, E.C. 4

1927

Price Fifteen Shillings net

PRINTED IN GREAT BRITAIN 
Szafa: 13

Pólkses 
rcin.org.pl 
rcin.org.pl 
History of the Physiological Society during its First Fifty Years

1876-1926 
rcin.org.pl 
rcin.org.pl 
EMithove Li Liden.
Av Hule. London.

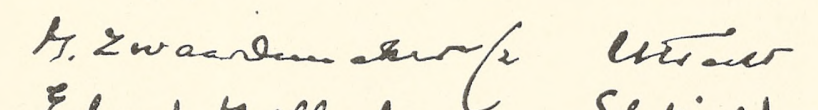

Ehand Hellandy Sexpield

Tr.Mrgims Mreeht.

Riromin bano Landon.

Mranyeluan. litechts

sara B/Readar. London

Scle gier chnoterwan

terightor Bramadil hamelestor

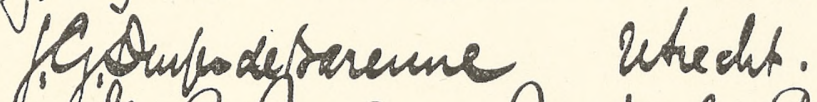

F's. R. Unow Inotieal Conada

FCrsergunsions Leiden

E. Clark

Ir vunderslorst

Arrangersyle.

to. a. mo smaro.

Mypis Minman London.

Gut. Unarenti:

Q9. Beadle

George Barger

Shon $\rightarrow .3$ ution

Must. Mnackeith

Lusin P. Fultow

R.a. Pites

Guwoef

Rolingon

loceurer

R D/anrence

B. Oemes of Kouson

9. Revenetutothes Amiterday

lop, senars hew youts

g. a gunn

7. de Haan

g.S. Adair.

Acthun tudum

Rathleen. s. Cark

Harold $\pi$ Hegall

?. lorted

Tis. Yaseser

Crinuman

Yosephiug Woy

Lethen.
Leiden.

Lavon

Oxford.

Idinturgh

artion

Caford.

arford

ozford.

Cocutriof.

Ladon.

Lindern

Lundou

Oxpord.

Groninger

Cambiridge

Tomelm.

Shaffield. Landon. V.It. Mottram

heiden

(Soforis) fondon

Utrecht

Caubridge

$\varepsilon$. hers res whande Kondon

HeRoaf London tTom heeums Leiser. maythellarby Sheffied H. H. Dale London.

C. Brinkler Whreent

E.G.T. Liddell Offord.

H. Hhischfeld Ceicles

Katthamie r.Conard. Landon. L.?. de Tough. Ambidaun.

Wimipede. Cullo London. - Alice sear Davies Laydon.

Q. D. Verrip, Leiden.

IA MSarmeyn, hauchester.

J. Tthanasin sucarest

D. N.riterman Amoteroom

H.D.Kay. Canbide.

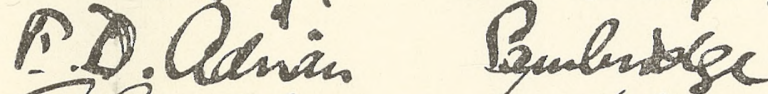

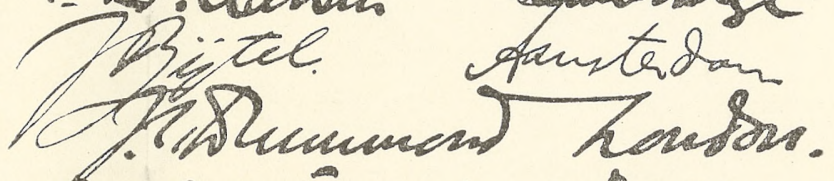

De Cohenicrvart utechs

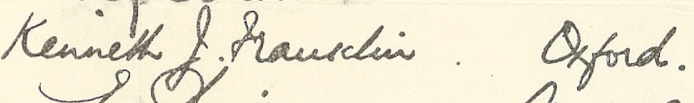

6. Dengemansen Arsonerizam.

C. Daltimo Louden

uphissma Ctreent.

Cuthn th. Inoster (1.Y) - London

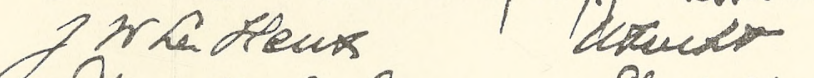

Ctraterto. C. Eaves. Sheffifd.

k. H. Tate (Choeland, O) havelon

(Cromed) J.S. Haldane Cambridge.

7.W Peras. Gx ford.

Winipred Paprons Combrige . 1t. Mottram ong, heches

Q. Ni. hoyens

C.J. M. Liddat.

C.I. M. Liddat. Oryoud. honono.

Sumone nor a Plyseriogus. 
rcin.org.pl 


\section{History of the Physiological Society during its First Fifty Years $1876-1926$}

BY

SIR EDWARD SHARPEY-SCHAFER, F.R.S.

Issued by the Society and published as a Supplement to the Journal of Physiology December, 1927 
$0_{0}^{05 w \cdot i n g}$

1982

PRINTED IN GREAT BRITAIN 


\section{PREFACE}

ThIs History is written at the request of the Society. In compiling it I have chiefly used the Minute Books, all of which have been preserved; but have also been able to obtain information from other sources such as diaries, letters, and journals. And I have throughout had my memory to fall back upon, having been a member since the foundation of the Society and retaining a keen recollection of most of the events in its history. Besides this I have had the ready assistance of several of the senior members of the Society, who have looked through the proofs and have offered valuable suggestions regarding them. In a compilation of the kind, containing so many personal references, it is difficult to prevent errors, both of omission and commission, creeping in. For any such errors I must accept the responsibility. I can only hope they may be few and offer an apology to any person who may have been affected by them.

The task of compilation has proved by no means so easy as it promised when, at a dinner of the Society, I lightly undertook it; but it has been a labour of love, and has served to remind me of many an old friendship and many a pleasant gathering. If it should assist in stimulating the interest of the members in their Society I shall be more than rewarded.

E. SHARPEY-SCHAFER

EDINBURGH

November, 1927. 
rcin.org.pl 


\title{
HISTORY OF THE PHYSIOLOGICAL SOCIETY, I876-1926
}

\author{
By SIR EDWARD SHARPEY-SCHAFER, F.R.S. \\ (Professor of Physiology in the University of Edinburgh.)
}

IN the middle part of the nineteenth century Great Britain was far behind France and Germany in the development of Physiology. We had no pure physiologists and it was considered that any surgeon or physician was competent to teach the science. Indeed, long after this, the subject was in many medical schools left in the hands of a member of the hospital staff, usually a young man, who carried on clinical teaching as well. Hence, during a period of time when other experimental sciences were rapidly progressing, Physiology in this country could show no names worthy to be mentioned with those of Magendie, Bernard, Müller, Helmholtz, or Ludwig, to mention but a few of the brilliant physiologists of France and Germany. In one place onlyUniversity College, London-was a lamp kept burning; the lamp was that of William Sharpey. Although Sharpey had received a purely anatomical training, he had manifested his physiological leaning by his investigations regarding the action of cilia, and he early familiarised himself with the microscopic appearances of, and changes in, living cells, as well as with the structure of animal tissues. This led to his having a wider outlook than that of the pure anatomist of that day, and it was a happy event for the future of Physiology in England that Sharpey was invited to occupy the newly instituted chair of General Anatomy and Physiology at University College, London, in 1836. It is true that his lectures were largely anatomical, that he carried out no physiological researches, that he performed no experiments on muscle and nerve other than those which had been performed by Galvani half a century earlier, that he never possessed a kymograph (the working of which he would illustrate to his class by revolving on the lecture table what Michael Foster called his "dear old hat"), but he had a remarkable grasp of the problems of physiology and a singular power of imparting his conclusions to his audience. Recognising his limitations in the matter of experimental investigation, he was none the less ready to encourage others to undertake research and was prepared to afford opportunities for carrying out such work at University College - although, in the absence of any proper laboratory accommodation, opportunities were scanty. 
But as the years progressed he began to feel that more should be done to encourage physiological work in this country, added to which he probably had the idea of the introduction of a successor to himself. $\mathrm{He}$ induced George Harley, then a rising physician, who had worked in Paris with Bernard, to start a class of Practical Physiology at University College ${ }^{1}$. But Harley, with a growing practice, soon found it impossible to continue this work. Sharpey then persuaded Michael Foster, a young man of about thirty, who had received his medical education at University College and Hospital and was engaged with his father in general practice in Huntingdon, to give up medicine and come to University College with the title of Professor of Practical Physiology. This appointment of Michael Foster proved a decisive factor in the history of Physiology in Great Britain.

Foster himself, although he had been Sharpey's medallist, had no special training in Physiology. He had a practical knowledge of Chemistry and Histology, and from visits to continental centres learned something of what was being done in France and Germany. Having accumulated certain physiological apparatus, including microscopes, he organised a course of practical instruction in a room which was allotted to him in the College, and which received the title of Physiological Laboratory. The course was not compulsory and was attended only by students who displayed a special interest in the subject and were willing to pay an extra fee. It consisted, as regards histology, of the examination of teased preparations of fresh tissues and of sections of organs made with a razor by chopping them on a glass slide, or, in the case of firmer tissues, by cutting them while held in a split cork. The chemical part embraced a study of the constituents of blood and serum, the spectroscopic appearances of hæmoglobin and its derivatives, the components of bile and urine, the phenomena of gastric and pancreatic digestion, the general properties of albumins, carbohydrates and fats. The experimental part was less complete, but the phenomena of nerveand muscle-physiology were investigated in the frog, as was also the action of the heart and the circulation-the latter both in the frog and mammal.

It will be seen that the course, although elementary, was planned on a sound basis by Foster, who displayed that capacity for organisation which was to have so much influence later in the promotion of Physiology in Cambridge.

1 Dr George Harley, F.R.S., was the first in this country to repeat the experiments of Brown-Séquard on the effect of extirpation of the suprarenal capsules. 
In addition to conducting the course of Practical Physiology, Foster used to give occasional lectures, with demonstrations, to Sharpey's class in the large Physiology Lecture Room.

This development of Physiology in University College soon exerted its influence outside the walls of that institution. Other medical schools in London began to start instruction on similar lines, and independent workers, who were for the most part active clinicians-conspicuous amongst whom was Pavy of Guy's Hospital-were encouraged by finding their scientific work better appreciated than was possible when it had merely to pass the criticism of fellow-practitioners. Amongst clinicians who at this time began to take an interest in Physiology was Burdon Sanderson, who had been for some time established in London. Falling under the influence of Sharpey, who made arrangements for him to perform experimental work at University College, he there carried out (in 1866) a series of experiments on the effects of respiration on the circulation. But the apparatus which he used for recording blood-pressure had serious disadvantages, and indeed he must have soon recognised that for the conduct of such investigations a familiarity with laboratory methods is essential. He was more fortunate in his studies of the pulse under normal and clinical conditions and published his results in a small monograph which came out in 1867 . The interest in Physiology which these studies displayed led to his being invited to become successor to Michael Foster.

This succession came about under the following circumstances. Professor George Murray Humphry, F.R.S. ${ }^{1}$, then Professor of Anatomy in Cambridge, who took a broad view of medical education and was anxious for its development in his own University, recognised that the first necessity for this was the foundation of a chair of Physiology. But the project was not then practicable, nor did it become so for some time. However, Humphry, with the aid of Mr Coutts Trotter and of Mr W. G. Clark, who were influential Fellows, and of Dr, afterwards Sir, George Paget, K.C.B., Physician to Addenbrooke's Hospital, persuaded Trinity College to start the ball rolling by establishing a Prælectorship of Physiology in the College ${ }^{2}$. The duties of the Prælector were to give lectures in Physiology to students, not only of the College but of the

1 Afterwards Sir G. M. Humphry. Humphry was the founder, in conjunction with Sir William Turner, of the Journal of Anatomy (1866) and in 1886 helped to found the Anatomical Society, of which he was the first President. He died in 1896 at the age of 76.

${ }^{2}$ The original suggestion came from George Henry Lewes and George Eliot, who were friends of W. G. Clark. Clark, who was elected Public Orator in 1857, was one of the editors of the newly established Journal of Philology. He died in 1878. 
University in general, who might desire instruction in that subject, and to organise laboratory work in conjunction with the lectures in a room allocated for this purpose. On Huxley's suggestion Michael Foster was asked to occupy the position thus created. Accordingly in 1870 he transferred his activities from London to Cambridge, and Burdon Sanderson was nominated to the chair of Practical Physiology in University College, with the understanding that he would also succeed to that of Physiology on Sharpey's retirement, an event which took place in $1874^{1}$.

Sanderson now relinquished his clinical appointments and henceforth devoted himself to Physiology, although continuing for some time his pathological work, chiefly on the communicability of tubercle ${ }^{2}$.

Both Foster at Cambridge and Sanderson in London quickly began to develop their subject, and each became surrounded by a group of young and earnest workers, many of whom went sooner or later abroad for the special training necessary for physiological work, which could not yet be obtained in their own country. At these two centres were established two schools of Physiology which have sent offshoots to all parts of the Empire, as well as to the United States. Both schools owed their origin to the teaching and influence of William Sharpey, who is with justice to be regarded as the real founder of modern Physiology in this country.

With the growth of Experimental Physiology, and the sister science Experimental Pathology, operations upon living animals necessarily began to multiply, and before long a vigorous anti-vivisection agitation sprang up ${ }^{3}$. As the result of the agitation the Government of the day appointed in 1875 a Royal Commission (presided over by Lord Cardwell)

1 Incidentally the writer here comes into the story. Having, along with Newell Martin, worked for some time with Foster at University College, both were invited to accompany him to Cambridge in 1870. Martin accepted the invitation and helped to found the Cambridge school of Physiology; he eventually migrated to Baltimore to take charge of the teaching of Physiology at the newly established Johns Hopkins University. The writer remained with Sanderson at University College as Assistant and Assistant Professor, and thirteen years later succeeded to the Chair, which he held for sixteen years, being himself succeeded in 1899 by E. H. Starling.

2 This was carried on in a private laboratory overlooking a mews at 18 Howland Street (now renumbered), and later at the Brown Animal Sanatory Institution in Wandsworth, of which he was appointed the first Superintendent.

3 It is not to be wondered at that the general public (ignorant of the fact that no science can advance without experiment and that, for a science dealing with life, experiments must be made upon the living subject; also not knowing that in the great majority of cases such experiments are performed painlessly under the influence of anæsthetics) was led, by the blood-curdling tales broadcasted by the anti-vivisection agitators, to voice a demand for the regulation or even the abolition of experiments on living animals. 
to investigate the subject and to report and advise as to whether it was necessary to take legislative steps in the matter. The representatives of Physiology on the Commission were Huxley and Erichsen ${ }^{1}$. After hearing an interminable amount of evidence on both sides, the Commissioners eventually produced a Report, which, like all such Reports, was a compromise. Although they had not been presented with any irrefutable evidence that acts of cruelty had been perpetrated upon animals in this country in the pursuit of physiological or pathological investigations, they nevertheless agreed to recommend that the practice of vivisection should be regulated by Act of Parliament and that it should only be permitted to persons to whom a licence had been granted by the Home Secretary on the advice of certain responsible authorities. For special experiments which might involve pain or in which, for various reasons, anæsthetics could not be employed during the whole course of the experiment, special certificates limiting the number and defining the scope of such experiments were to be obtained and signed by the same authorities, the operation of these certificates being subject to the veto of the Home Secretary. In consequence of the Report of the Royal Commission and the knowledge that it was the intention of the Government to bring in a Bill dealing with the subject, it was evidently desirable for physiologists to form an association which might come into communication with the minister in whose hands the conduct of the Bill would be placed, with the view of modifying proposals which seemed to hamper unduly the progress of experimental medicine. Thus the anti-vivisection agitation was the cause of the formation of the Physiological Society. Ex malo bonum!

\section{FOUNDATION OF THE SOCIETY}

As a result of the events just narrated, the Physiological Society was founded by nineteen persons interested in Physiology who met at the house of Dr John Burdon Sanderson in response to his invitation. A facsimile of the invitation, as addressed to the writer, is appended ${ }^{2}$.

1 Sir John Eric Erichsen, F.R.S., Professor of Clinical Surgery at University College, and Surgeon to University College Hospital. Erichsen became the first Inspector under the new Act, and had, to assist him in the work, Dr George Vivian Poore, Assistant Physician and afterwards Physician in the same Hospital. On Erichsen's retirement Poore became Chief Inspector. He again was succeeded by Sir George Thane. On Thane's resignation $\mathrm{Mr}$ J. A. Giles was made Chief Inspector and still holds the appointment.

2 The body of the letter is in Mrs Sanderson's handwriting. 
49, QUEEN ANNE STREET.

$$
\text { Kraveh - } 28 \text { ter } 18 \% 6
$$

Suy dear Schafer

$$
\text { Hi is finsporad to }
$$

hold a hucting at huy koudg at s.3o f.m. On Fiday keyt (उie) of a finchinisiary chasacter, for the prisferse of crasidensing thether any, or What Mlefes rught to be tatien with reforesce to the Reennkendationit of dord Condurete: Commifurn. St will prostaty 


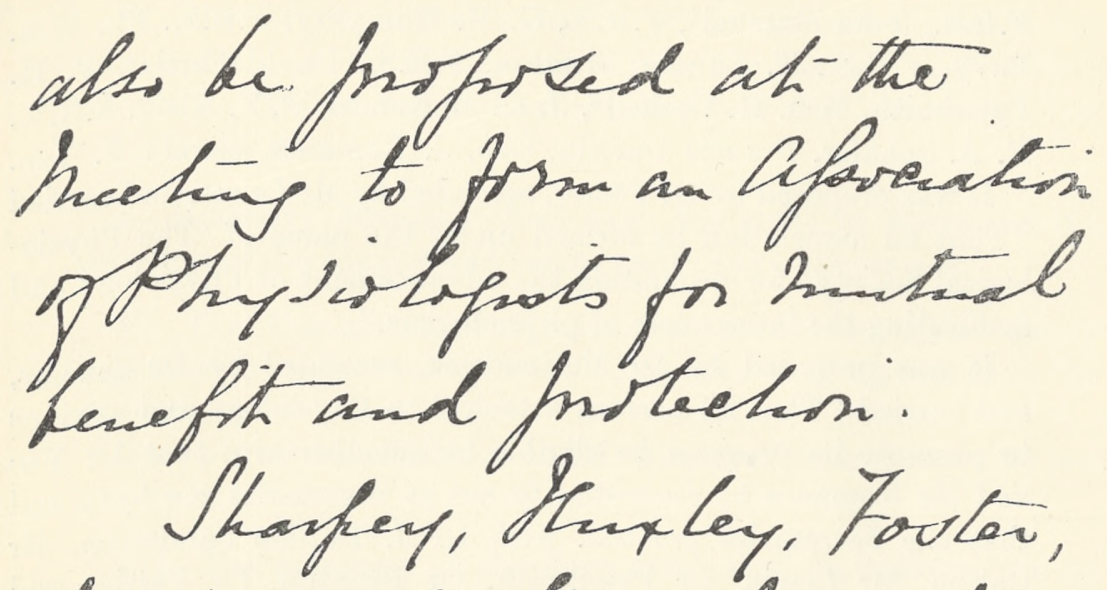

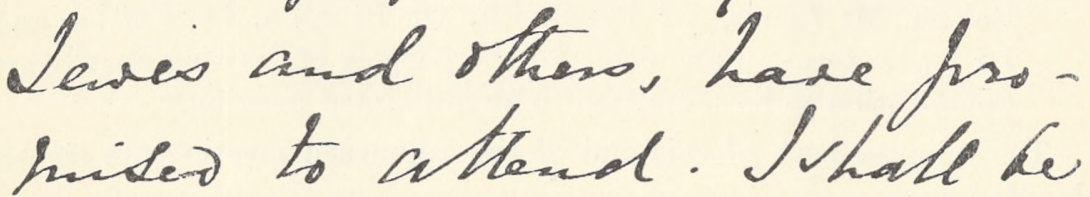

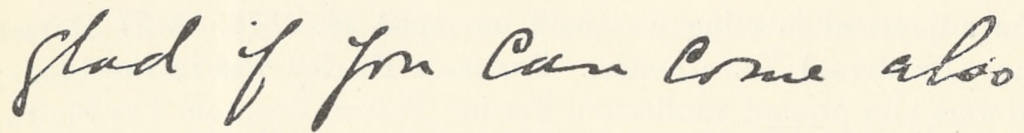

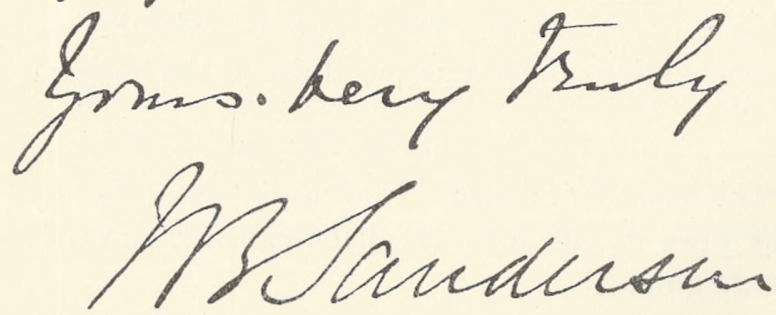

The proceedings of the meeting are chronicled in the first Minute Book $^{1}$ of the Society as follows:

At a meeting held on the 31st March, 1876, at 49 Queen Anne Street, Dr J. Burdon Sanderson in the Chair.

Were also present: Wm. Sharpey, F.R.S., Thos. H. Huxley, F.R.S., Michael Foster, F.R.S., Geo. H. Lewes, Francis Galton,

1 This Minute Book was lost for more than twenty years, all attempts to discover its whereabouts having been unavailing. It was accidentally found by Sir Charles Sherrington in a cellar in the old part of the Physiological Laboratory at Oxford, amongst a number of loose papers; it seems to have been there since Burdon Sanderson's time. It is now the most valued possession of the Society. 
F.R.S., John Marshal ${ }^{1}$, F.R.S., G. M. Humphry, F.R.S., Fk. Wm. Pavy, F.R.S., T. Lauder Brunton, F.R.S., David Ferrier, P. H. Pye-Smith, Wm. H. Gaskell ${ }^{2}$, J. G. McKendrick ${ }^{3}$, E. Klein, F.R.S., E. A. Schäfer, Francis Darwin, Geo. J. Romanes, Gerald F. Yeo. It was proposed by Dr Foster, seconded by Mr Lewes, and carried "That an association be formed under the name of "The Physiological Society' for promoting the advancement of Physiology and facilitating the intercourse of physiologists."

It was proposed by Dr McKendrick, seconded by Dr Schäfer, and carried "That all persons attached to Physiology and anxious to promote its progress be eligible for membership; that Dr Yeo and Mr Romanes be requested to act as Secretaries pro tem., and that the Secretaries pro tem. with Dr J. Burdon Sanderson, Mr Galton, Mr Lewes, Dr Pye-Smith, Dr Brunton, Dr Ferrier and Dr Foster form a Committee for the purpose of drawing up a Draft Constitution to be submitted to an adjourned meeting."

The minutes both of this and of the adjourned meeting are signed by $\mathrm{Mr}$ Lewes.

The adjourned meeting was held on April 26, 1876, at 37 Dorset Square (Dr Gerald Yeo's house). Professor Huxley was in the Chair; there were also present Sanderson, Ferrier, Foster, Brunton, Pye-Smith, Yeo, Galton and Romanes. The Draft Constitution was submitted, and after emendation adopted as the Rules of the Society.

\section{FIRST RULES OF THE SOCIETY}

I. This Society is called "The Physiological Society."

[The present rule says "shall be called": not an improvement on the original.]

II. The Society is instituted for promoting the advancement of Physiology and facilitating the intercourse of Physiologists.

III. The Society shall consist of not more than Forty members, all of whom shall be working physiologists.

[This number is now unlimited and the qualification has been abandoned: it was always a dead letter.]

1 Should be John Marshall, a distinguished surgeon attached to University College Hospital, and an old pupil of Sharpey. He published a Text-book of Physiology in two volumes, largely based on notes from Sharpey's lectures. He was President of the Royal College of Surgeons 1883-88. He was elected an Honorary Member of the Society in 1882. $\mathrm{He}$ died in 1890.

2 Should be Walter H. Gaskell.

${ }^{3}$ Professor of Physiology in Glasgow from 1876 to 1906. He died January 2nd, 1926. 
IV. Men of distinction in Science who have contributed to the advancement of Physiology are eligible for election as Honorary Members. The number of Honorary Members shall not exceed five.

[It is now twelve.]

V. Honorary Members shall have the right of attending the meetings of the Society and taking part in the discussions.

VI. The Committee shall nominate candidates from names suggested by members to fill the vacancies which may exist in the Society.

[In view of the alteration in III, the latter part of this rule has dropped out.]

VII. The nominees of the Committee shall be balloted for by the Society at the Annual General Meeting.

[A second meeting for election of members has been added.]

VIII. One black-ball in three shall exclude.

[This is now more rigorous, viz. one in five; rather unnecessarily so, considering that only candidates selected by the Committee are balloted for.]

IX. One full week before the meeting at which the Ballot is to take place the Secretaries shall send to each member a ballot-paper containing the names of the candidates nominated by the Committee.

[Their qualifications and the names of their proposers are now added to the ballot-paper and the method of marking this is prescribed.]

$\mathrm{X}$. Any member unable to attend the annual meeting can vote by sending his ballot-paper enclosed in an envelope, bearing his name, to the Secretaries on or before the day of Ballot. The Chairman shall open such envelopes and place the ballot-paper in the box.

XI. Each ordinary member shall pay an annual subscription of ten shillings. The charge for dining shall be additional.

[The subscription was raised to one pound in 1884, to one pound five shillings in 1888, to one pound eleven shillings and sixpence in 1890, and is now two guineas. But each member now receives the Journal of Physiology without additional payment.] 
XII. The subscription is payable in advance and becomes due on the 1st of November.

[This has been changed to January 1st.]

XIII. Any member whose subscription is not paid within twelve months after it has become due shall cease to be a member of the Society.

XIV. Any ordinary member who has not attended at least one meeting during the year shall cease, ipso facto, to be a member, unless he shall satisfy the Committee that his absence arose from unavoidable circumstances.

[This became a dead letter and was eventually repealed.]

XV. The meetings shall be held on the Second Thursday in the months of November, December, January, February, March and May.

[Since 1884 the day of meeting has been changed to Saturday, and the number of meetings in the year has been increased.]

XVI. At each meeting one of the members shall, on the motion of one of the Secretaries, be elected to act as Chairman.

[This rule still holds good for General Meetings; but after the Society began to hold scientific meetings in laboratories it became usual for the head of the laboratory to act as Chairman.]

XVII. The duties of the Chairman shall be to control the order of proceeding, and generally to direct the business of the meeting.

XVIII. The meetings of the Society shall commence with dinner at six o'clock punctually. The Business shall commence at seven o'clock exactly.

Members not wishing to dine may join the meeting at any time after dinner.

[This rule is interesting as establishing the fact that the Society was originally intended to be a dining club. The early hour seems to have been prescribed to enable members residing in Cambridge to catch the last train back. The time for commencing dinner was afterwards changed to seven o'clock; in the existing rules nothing is said about a dinner. But one of these (XXVII) appears to assume that a dinner is still a part of the proceedings since it reads "Each member intending to be present at dinner shall send notice, etc.; 
and if he introduce a visitor, must at the same time forward the name of the guest." A dinner is no longer necessary; but, although not specified in the existing rules, business matters are still almost invariably discussed after dinner.]

XIX. The Chairman shall vacate the Chair at eight o'clock, unless a motion to the contrary be put and carried.

XX. Each member shall have the privilege of introducing a visitor, whose name shall be entered on the minutes.

XXI. The Annual General Meeting shall be held on the Second Thursday in May, when the Secretaries' report and statement of accounts shall be laid before the Society.

[The Annual Meeting is now held in March, after October and January had been successively tried.]

XXII. At the Annual General Meeting two Secretaries shall be elected for the ensuing year, and also seven members, who, together with the Secretaries, shall act as a Committee of Reference and Nomination.

[There are now two Secretaries and a Treasurer, besides thirteen ordinary members of Committee. In addition the Chairman of the Editorial Board of the Journal of Physiology and the Editor of Physiological Abstracts are ex officio members of Committee. Since these two Journals have been acquired by the Society it has become necessary to appoint Trustees to hold property on its behalf. No provision of this nature is contained in the original rules, and the Society, not being chartered or incorporated, has hitherto been unable to accept gifts or legacies. The change was made in 1926.]

XXIII. Not more than five members of the Committee shall be eligible for re-election. [This is now ten.] Any member may suggest the name of a candidate to serve on the Committee by sending the proposed name to the Secretaries at least four weeks before the Annual General Meeting.

XXIV. One full week before the Annual General Meeting the Secretaries shall send to each member a balloting list containing the names of the Committee, together with the names suggested to fill the vacancies.

XXV. The Society shall elect the Committee by ballot (as in 
Rule X): each member striking out at least two names [now three] from the Committee list, and prefixing a mark to those of the suggested names which he may wish to substitute.

XXVI. The Secretaries shall send to all the members of the Society notices of each meeting, and when possible the subject to be brought forward. Such communications as shall be thus notified shall have priority.

[Demonstrations now have priority over verbal communications at the scientific meetings which have since been established; the latter were not contemplated at the formation of the Society.]

XXVII. Each member intending to be present at the dinner shall send notice to that effect to the Secretaries on the Monday previous to the meeting. And in case he intend to introduce a visitor he shall at the same time forward the name of his guest.

XXVIII. If at any time the Committee shall be of opinion that the interests of the Society require the expulsion of a member they shall submit the question to a Special General Meeting, at which if two-thirds of the members of the Society vote (by ballot as in Rules IX and X) for the expulsion of the member in question, his subscription for the current year shall be returned to him and he shall thereupon cease to be a member of the Society.

The copy of these rules in the minute book is signed 5th May 1876, G. H. Lewes.

Considering with what care the original rules were drawn up and the experienced men who framed them, it is curious that there should be no special provision for alterations. This defect has now been rectified; but before this was done alterations were frequently made, at any meeting and without special notice.

\section{ORIGINAL MEMBERS OF THE SOCIETY}

The next meeting was held on May 5th, 1876, at 18 Cornwall Terrace (Mr Romanes' house). Mr George Henry Lewes was in the Chair and the following were also present: Drs Sanderson, Power ${ }^{1}$, Ferrier, Yeo

$1 \mathrm{Mr}$ Henry Power, F.R.C.S., was Lecturer on Physiology and subsequently Ophthalmic Surgeon at St Bartholomew's Hospital. He edited Carpenter's Physiology, a monumental compilation which was in considerable demand at this time in consequence of the lack of less voluminous text-books. He died in 1911. 
and $\mathrm{Mr}$ Romanes. At this meeting it was determined that the first Annual Meeting of the Society should be held on the 26th of the present month (May) and that the Rules should be printed and circulated amongst the following physiologists, "who shall be invited to become members and attend the next meeting of the Society." The list comprises two Honorary Members, Charles Darwin, F.R.S. and William Sharpey, F.R.S., and the following ordinary members: Francis Maitland Balfour (Cambridge), T. Lauder Brunton, F.R.S. (London), William B. Carpenter* (London), Richard Caton (Liverpool), Francis Darwin (Down), A. G. Dew-Smith (Cambridge), Thiselton Dyer (Kew), David Ferrier (London), Michael Foster, F.R.S. (Cambridge), Francis Galton, F.R.S. (London), Arthur Gamgee, F.R.S. (Manchester), Alfred H. Garrod* (London), W. H. Gaskell (Cambridge), G. M. Humphry, F.R.S. (Cambridge), Thos. H. Huxley, F.R.S. (London), E. Klein, F.R.S. (London), J. N. Langley (Cambridge), E. Ray Lankester, F.R.S. (Oxford), George H. Lewes (London), John Marshall, F.R.S. (London), Henry Newell Martin (Cambridge), Jeremiah McCarthy (London), Robert McDonnell, F.R.S. (Dublin), John G. McKendrick (Glasgow), F. W. Pavy, F.R.S. (London), P. H. Pye-Smith (London), Henry Power (London), Benjamin W. Richardson (London), George Rolleston* (Oxford), George J. Romanes (London), William Rutherford (Edinburgh), J. Burdon Sanderson, F.R.S. (London), Edward A. Schäfer (London), Gerald F. Yeo (London), C. Yule (Oxford).

Of the above names those marked with an asterisk are crossed out in the Minute Book, with the note "Refused to join." Dr Carpenter was, however, present as a guest at the inaugural banquet. He was elected an Honorary Member in 1882. Humphry resigned in 1877.

Mr Thiselton Dyer (F.R.S. 1880), born 1843, was Assistant Director of the Royal Gardens, Kew, and afterwards Director (from 1885 to 1905), in succession to Sir Joseph Hooker, whose daughter he married. He is now Sir W. T. Thiselton-Dyer, K.C.M.G., C.I.E.

Mr Jeremiah McCarthy, F.R.C.S., was born in Dublin, and graduated at Trinity College. He became Assistant Surgeon (1869), Surgeon (1883) and Lecturer on Physiology (1873 to 1893) at the London Hospital, from which he retired in 1898. He died in 1924, at the age of 88 .

Dr George Rolleston (F.R.S.) was Linacre Professor of Comparative Anatomy in the University of Oxford.

Dr Benjamin W. Richardson (F.R.S. 1867) was a London 


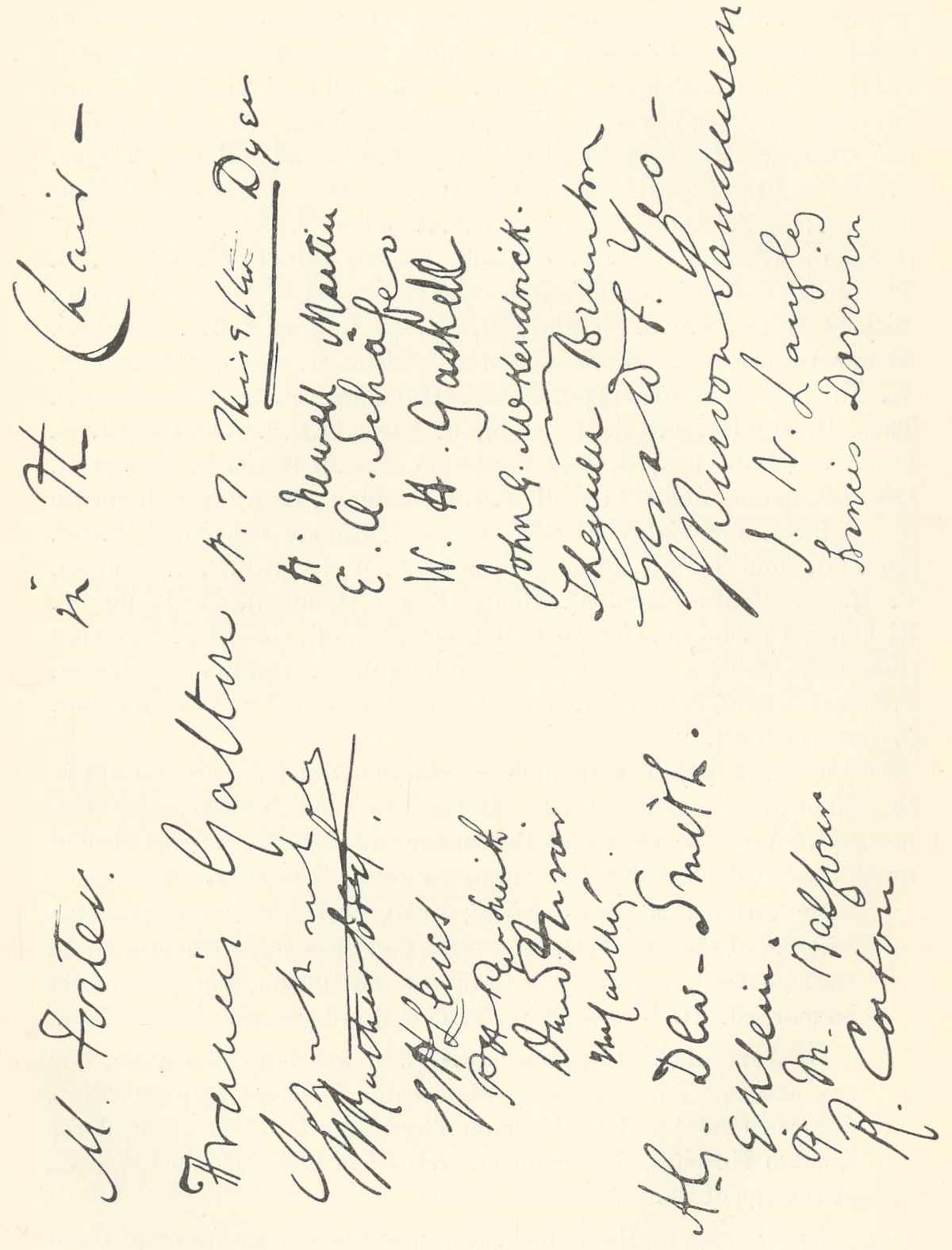


physician who wrote on physiological and pharmacological subjects. $\mathrm{He}$ introduced methylene chloride as a general anæsthetic and ether spray as a local anæsthetic. He developed-in an essay which received the Astley Cooper Prize (1856)-the conception that coagulation of drawn blood is due to escape of free ammonia, a theory which was demolished by Lister in his Croonian Lecture for 1863. He was knighted in 1893. He died in 1896.

Mr C. Yule was a Fellow of and Lecturer on Physiology in Magdalen College.

Most of the other original members are referred to elsewhere. Four are still living, namely, Sir W. T. Thiselton-Dyer, Sir David Ferrier ${ }^{1}$, Sir E. Ray Lankester and the writer, but only the last mentioned has remained a member throughout.

\section{INAUGURAL MEETING OF THE SOCIETY}

The various meetings the proceedings of which have been chronicled above were of a preliminary nature. The next meeting was the actual inaugural meeting, which was appropriately celebrated in the customary English fashion by a dinner. This was held at the Criterion Restaurant, Regent-now Piccadilly-Circus, on Friday, May 26th, 1876. As it was not only the first meeting but the only occasion on which the members of the Society who were present signed their names in the Minute Book, it is interesting to reproduce the page.

It will be seen that they numbered twenty-two in all. There were in addition fourteen guests (who did not sign) including four foreign physiologists-Donders of Utrecht, Marey and François-Franck of Paris, and Lovèn of Stockholm. Amongst the guests of British nationality the outstanding names are those of William Bowman, William B. Carpenter and William Marcet.

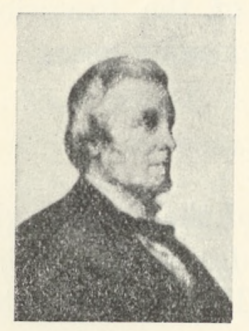

William Bowman, F.R.S., afterwards Sir William Bowman, Bart., had distinguished himself early in his career by his epoch-making observations on the structure of striated muscle, on the intrinsic muscles of the eye, especially the ciliary muscle, and on the structure of the kidney and the relations of the Malpighian bodies to the tubules and of the blood vessels to both. By this time, however, he had given up purely scientific work, and had

${ }^{1}$ Sir David Ferrier was elected an Honorary Member in January, 1927. 
specialised in ophthalmic surgery, in which he had a very considerable practice. Of high attainments, he was, nevertheless, possessed of a singularly gentle and modest disposition, and no one who had the honour of his acquaintance could fail to entertain an affectionate regard for him. Although no longer working at Physiology himself, he was a constant source of encouragement to younger workers. $\mathrm{He}$ did not join the Society as an ordinary member-he probably considered he was not sufficiently in touch with modern Physiologybut in 1882 was elected an Honorary Member, a mark of esteem he much appreciated. He died in 1892.

Dr William B. Carpenter, F.R.S., who probably declined the invitation to join the Society because he felt he could no longer regard himself as a physiologist, was at this time Registrar of the University of London. He was the author of the large work on Physiology already referred to as edited by Henry Power. In 1882 he was elected an Honorary Member of the Society. He died in 1886.

Dr William Marcet, F.R.S., subsequently joined the Society as an ordinary member (see p. 54).

The menu of the dinner is preserved in the Minute Book and does credit to the gastronomic abilities of the members.

After dinner the following toasts were proposed:

By the Chairman, "Her Most Gracious Majesty the Queen."

By Mr G. H. Lewes, "Foreign Physiologists," responded to by Donders and Marey

By Professor Rutherford, "Our Guests," responded to by Carpenter and Bowman.

The new-born Society was not itself toasted, but this omission does not appear to have hindered its development.

The only business done was the confirmation of the Provisional Committee as the Committee of the Society for the ensuing year.

\section{FOUNDERS OF THE SOCIETY}

Before proceeding to narrate the further history of the Physiological Society, it will not be uninteresting to furnish some description of those who were principally responsible for its formation. The portraits which accompany these descriptions were in most cases taken at about the time of the foundation of the Society. In a few instances it has been impossible to obtain these, and later photographs have been used. 


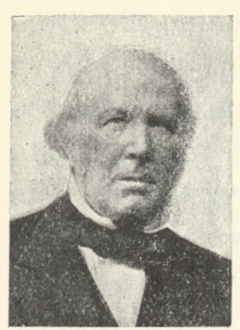

William Sharper ${ }^{1}$ was born at Arbroath on April 1st, $1802^{2}$. His father was a native of Folkestone but was married to a lady of Arbroath, in Forfarshire. The father died before the birth of his son. The mother married again; her second husband was Dr Arrott, a practitioner of Arbroath, by whom William Sharpey was brought up along with several half-brothers and sisters. Sharpey was sent to Edinburgh University in 1817, when he was only 15 years old; he began by studying Greek and Natural Philosophy, but the next year he transferred to the Faculty of Medicine. In 1821, at the age of 19, he obtained the Diploma of the Edinburgh College of Surgeons. He graduated M.D. in 1823, having in the meantime pursued studies in Anatomy in London, and in Surgery in Paris (under Dupuytren). After graduation he spent another year at the hospitals of Paris and studied Natural History at the Jardin des Plantes. Eventually he decided to give up the pursuit of Medicine and devote himself to Anatomy and, incidentally, to Physiology. With the view of obtaining information on these subjects he spent several months travelling on the Continent, for the most part walking with a knapsack; he finally settled down in Berlin in autumn 1828. Here he worked under Rudolphi, dissecting assiduously for several hours a day. On returning to Edinburgh in 1829 he continued to engage in microscopical and anatomical researches and collected materials for illustrating a course of lectures. He established himself as an extra-mural Lecturer in 1831, and attracted large numbers to his classes. His chief work at this time was on the distribution and the action of cilia in the Animal Kingdom. His observations were published in the Edinburgh Medical and Surgical Journal and in the Edinburgh New Philosophical Journal, and later formed the basis of an article in Todd and Bowman's Cyclopaedia of Anatomy and Physiology published in 1836. As already intimated, when it was decided in 1836 to establish a separate chair of General (or Physiological) Anatomy and Physiology in University College, he was invited to occupy it, and continued to do so until 1874, when he retired in favour of Burdon Sanderson. His work during the early part of his tenure of the chair was chiefly microscopical and concerned with the structure of the tissues, especially the structure and development of bone-his observations on the subject form the basis of our present

1 The name Sharpey seems to be rare: it does not occur in the London Post Office Directory.

${ }^{2}$ April 1st was also the birthday of William Harvey, who was born at Folkestone in 1578. PH. 
knowledge. They were published in the fifth edition of Quain's Anatomy - a book originally written by Jones Quain but at this time edited along with Sharpey by his better known brother Richard Quain, a celebrated anatomist and surgeon, the author of a folio on the arteries of the human body-finely illustrated by Maclise. The Microscopic Anatomy of Quain was re-written by Sharpey and is a monument to his powers of observation and description. He remained connected with the work as one of the editors until the time of his death.

Sharpey was on intimate terms with Kölliker, who began as a physiologist but having been invited to the Chair of Anatomy at Würzburg became the leading histologist of his day. It is to Kölliker that we owe the term "Sharpey's fibres," given to the perforating fibres of bone which Sharpey had described.

Sharpey himself gradually gave up original investigations and devoted himself to teaching and administrative work. He was a great teacher: all his pupils have testified to this ${ }^{1}$. He had the unusual gift of being able to recognise every student of his class and to remember the name of each one, although hundreds attended his lectures. Not only did he know them, but he took pains to learn all about them and could recall their circumstances and career even after many years.

Sharpey's personal qualities were such as to inspire his pupils and friends with esteem and affection. He had a gentle nature, a genial disposition and a sound judgment. He was devoted to the interests of the institutions with which he was connected, especially University College and the Royal Society. He spared no pains to promote the advancement of Physiology, and was full of encouragement to young men desirous of engaging in original work in that and cognate subjects. He knew and was known to everybody in the world of medicine and science. Wise in council, he exercised a very considerable influence on medical education, and was universally esteemed by members of the profession. The Sharpey Physiological Scholarship at University College was founded in 1870 as a memorial to him: he left to it a further endowment at his death. He continued to lecture until 1874, when he resigned the chair and was succeeded by Burdon Sanderson. He presented his valuable library to University College, spending the last years of his life in preparing a catalogue of the numerous books and pamphlets on Physiology and allied subjects of which it was composed. He was elected F.R.S.

1 Lister refers to him as "our great master" and writes "as a student at University College I was greatly attracted by Dr Sharpey's lectures, which inspired me with a love of physiology that has never left me." 
in 1839 and acted as Biological Secretary of the Royal Society for nineteen years (1853 to 1872). He was also for many years a member of the General Medical Council.

He died in 1880 at the age of 78 . His body was followed from University College to Euston for conveyance to Arbroath-in the Abbey Kirkyard of which he is buried - by a vast cortège of persons who desired thus to testify their affection and regret. He did not marry; his only remaining relative was his nephew, Major Colville, an army surgeon, who survived him but a short time.

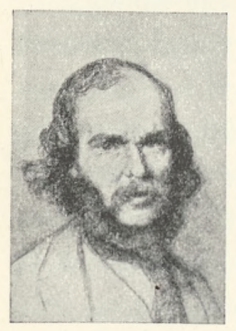

George Henry Lewes was born in 1817, and was, except Sharpey, the oldest of the founders of the Society. He presided over more than one of the preliminary meetings and was a member of the first Committee. He began, although he did not pursue, the study of medicine, and incidentally acquired a special interest in Physiology. He is best known as an author and journalist. He was the first editor of the Fortnightly. His work on The Biographical History of Philosophy (1845) won for him a well-merited reputation which was greatly enhanced by the appearance of the Life and Works of Goethe in 1855. For this undertaking he was particularly qualified, having lived in Germany and being versed in German literature. His interest in Physiology and Natural History is shown in several of his subsidiary writings. He died in 1878. As is well known, Mary Ann Evans (George Eliot) the distinguished author, lived with him for twenty-four years; the constant encouragement and intelligent criticism which he furnished greatly aided the development of her literary genius. The George Henry Lewes Scholarship, founded by her at Cambridge, is a permanent memorial to his attachment to the science of Physiology.

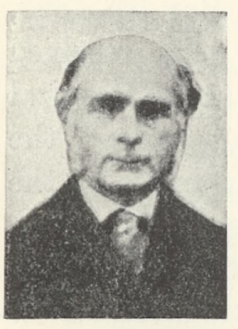

Francis Galton, a grandson of Erasmus Darwin and cousin of Charles Darwin, was born in 1822, and was therefore 54 years old at the founding of the Physiological Society. He also was not a physiologist, although he had commenced the study of medicine at King's College, London; but he took deep interest in Physiology from its bearing on the subject of heredity. In 1840 he entered Trinity College, Cambridge, where he spent three years. He started life as a traveller and explorer in unknown parts of Africa, and only later took up what was to be the main 
work of his life. His best known book, Hereditary Genius, was published in 1869. This was followed by several others of similar nature. Galton was one of the first to draw attention to the characteristic individuality of finger-prints and their immutability throughout life. His interest in Meteorology was manifested in an important work, Meteorographica, published in 1863: in this the first use of the term "anticyclone" occurs. The details of his biography and family history are to be found in an autobiographical sketch entitled Memories of my Life, and in the monumental biography (not yet completed) by Karl Pearson, the eminent mathematician, Professor of Eugenics in University College-occupant of a chair founded by Galton for the prosecution of study and research in Heredity, and endowed with his residual estate.

Galton was a delightful personality, the most modest and unassuming of men, and one of the most cultured. Always eager to acquire new knowledge, and himself primed with accurate information on the subjects which interested him, he would discuss them in such a manner as to put even the youngest scientific companion entirely at ease.

The Physiological Society was fortunate in reckoning Francis Galton among its founders. A member of the first Committee which was charged with drawing up the Rules of the Society, he took great interest in its formation, and frequently attended the dinners, on several occasions occupying the chair. Galton received the Gold Medal of the Royal Geographical Society in 1853. He was Secretary of the British Association from 1863 to 1868 , but declined the Presidency. He was elected to the Royal Society in 1856, was awarded a Royal Medal in 1886; the Huxley Medal of the Anthropological Institute in 1901; the Darwin Medal of the Royal Society in 1902; a special Darwin-Wallace Medal of the Linnæan Society in 1908; and the Copley Medal of the Royal Society in 1910. He was knighted in 1909. He died in 1911.

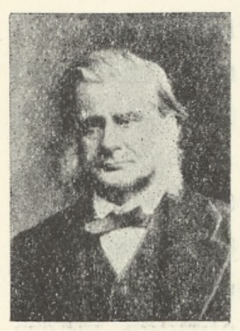

Thomas Henry Huxley was born on May 4th, 1825, and would therefore be about fifty. He received his medical education at the Charing Cross Hospital Medical School ${ }^{1}$, and, after qualifying, entered the Navy as Assistant Surgeon, being appointed to the "Rattlesnake," a vessel which was engaged in the years 1846-50 in surveying at first off South America and South Africa, and afterwards in Australia and New

1 Where he was greatly influenced by Wharton Jones, who was at the time Lecturer in Physiology there. "I do not know that I have ever felt so much respect for anybody 
Guinea, especially charting the passage between the mainland of Australia and the Barrier Reef. During this voyage Huxley made numerous observations on the marine organisms which he observed and collected, his papers describing the results being accepted and published by the Royal and Linnæan Societies. He was recognised as a leading authority on the subjects they dealt with-especially the Cœlenterata-and on his return he was elected F.R.S. (in 1851) at the early age of 26 . Soon after he was appointed Professor of Natural History at the Royal School of Mines: this office was subsequently merged into the Professorship of Biology in the Royal College of Science. In this capacity he continued to teach and to train teachers in Biology for many years. He also lectured for some time on Comparative Anatomy at the Royal College of Surgeons. His researches, although at first confined to Invertebrata, were soon extended to the Vertebrate sub-kingdom, and included important investigations in Palæontology and Anthropology. He had a remarkable power of exposition both in his lectures and his writings. His essays are models of composition: better English has never been written. As a public speaker he was without equal. President of the British Association in 1870, and Biological Secretary of the Royal Society from 1872 to 1883 (succeeding Sharpey in that office, and being himself succeeded by Foster), he was then elected President, an office he held for a short time only, being compelled by ill health to relinquish it in 1885 .

Huxley was one of the first naturalists to recognise the importance of the Darwinian theory and was its most noted protagonist. The position he took up with regard to evolution involved him in many controversies with the exponents of what were then considered orthodox views as to creation. His antagonists in these controversies must frequently have regretted that they had ventured to enter the lists against him, for he was able to demolish their arguments by the accuracy of his knowledgescientific, historical and biblical-so that they found their own weapons turned against themselves. Although a formidable controversialist in public, Huxley was in private a charming conversationalist. Ready to give advice and information when it was asked for, he was equally ready to receive information regarding any subject with which he was not familiar, and deprecatory in expressing opinions on matters regarding which he had no personal experience. The encouragement he gave to

as a teacher before or since" (Life, p. 20). Lister also came under the influence of Wharton Jones, after the latter had migrated to University College (Lord Lister, by Rickman J. Godlee, p. 16). 
young workers in biological science secured for him the gratitude and affection of all who came under his influence. He died in 1895, full of honours and deeply regretted. His Life-by his son-was published in 1897.

It will be readily understood that Huxley's name was a tower of strength in support of the infant Physiological Society. Although the author of a small Elementary Physiology, in which the salient facts of Anatomy and Physiology were expounded with characteristic clarity, he was, strictly speaking, a morphologist, not a physiologist. $\mathrm{He}$ attended, and even presided at, several of the earlier meetings of the Society. In 1882 he was elected an Honorary Member.

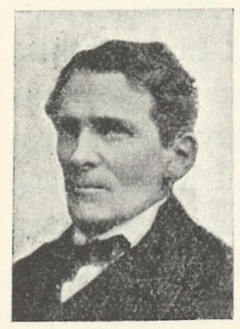

John Scott Burdon Sanderson was born in 1828, the second son of a Northumberland squire; he passed his early life in country pursuits - hunting, shooting and fishing. His father became "converted" whilst his son was still young, and joined the Plymouth Brethren: as an eventual result of this change in his religious convictions, he could not reconcile it with his conscience to send his son to his own University (Oxford) on account of the religious tests then necessary, and John accordingly went to Edinburgh at the age of 19. Curiously enough, Michael Foster was prevented from entering the University of Cambridge as an undergraduate for a similar reason.

Although his father wished him to study law, he had no inclination to do so, but preferred medicine: in which subject he took his degree in 1851.

Law was prominently in the family. John's grandfather, after whom he had been named John Scott, was Lord Chancellor Eldon; John's nephew is Lord Haldane, who has twice filled the office of Lord Chancellor. And his wife's brother, Lord Herschell, occupied the woolsack during one of Mr Gladstone's administrations.

At Edinburgh Sanderson came especially under the influence of the Professors of Botany (John Hutton Balfour), Anatomy (John Goodsir), and Physiology, or, as it was then called, the Institutes of Medicine (Hughes Bennett). After graduating he went to Paris where he spent several months, attending the hospitals, and studying Chemistry with Gerhardt and Wurtz, Embryology with Coste, and Physiology with Claude Bernard, whom he regarded as "the most inspiring teacher, the 
most profound thinker, and the most remarkable experimentalist he had ever known ${ }^{1} . "$

After his marriage in 1853 he settled in London, and joined the staff of St Mary's Hospital. He was for a time Lecturer on Botany, a subject towards which he always had a particular leaning, and about this time contributed to Todd and Bowman's Cyclopcedia an article on "Vegetable Reproduction." In the following year he was elected Medical Officer of Health for Paddington; the duties of that office were anything but a sinecure, but he performed them conscientiously during twelve years. Long before the end of this time Burdon Sanderson's name had become well known in connection with Public Health work and especially with the causation of diphtheria and cholera. He had been appointed Assistant Physician both to the Brompton Hospital for Consumption and to the Middlesex Hospital, and besides this clinical practice was doing a large amount of inspection work under the Medical Officer of the Privy Council. He was even invited to investigate for the Government a serious attack of cerebrospinal meningitis in the neighbourhood of Dantzig; this was followed by an enquiry into the nature of cattle plague. His report on this affection was described by Koch as "the best etiological and pathological investigation of the disease that has been made." In spite of all this work he found time to engage in physiological research, and investigated for the Royal Medico-Chirurgical Society the causation of death by drowning and the means of attempting recovery. He was instrumental in forming the Clinical Society, which, like the Physiological Society, was born at his house in Queen Anne Street: it is now merged with many other societies into the Royal Society of Medicine. From 1870 he devoted himself to Physiology. His most notable work in that subject was on problems of electrophysiology (muscle, the heart, Dioncea): he continued to pursue these researches after he had retired from teaching. His career has been already in part dealt with in connexion with the history of modern Physiology in Great Britain.

Burdon Sanderson had a striking appearance and personality. No one could fail to recognise that he was no ordinary mortal. Somewhat gaunt in appearance, but with a clean intellectual face and a striking gentleness of manner, he must have disappointed the worthy anti-vivisectionists at Oxford, who were prepared, on his appointment there, to give him and his projected new laboratory an antipathetic welcome: but he soon became one of the most popular figures in the University. $\mathrm{He}$ was absent-minded to a degree; many stories were circulated about

1 F. Gotch, obituary notice in Proc. Roy. Soc. vol. 79, 1907. 
this trait in his character: some of them true. A certain number of men who afterwards attained distinction worked under him, but their number was insignificant in comparison with those attracted by Foster at Cambridge. For, although Sanderson was himself a strenuous worker, he appeared not to have the same power of instigating research as his Cambridge colleague. He was not an impressive lecturer. He seemed to find it difficult to put things into plain language and to give their proportional value to the several parts of a subject. He would take immense pains to explain his meaning, repeating much the same thing in other words, and leaving his audience still more bewildered. But everyone felt it a privilege to work with and study under him. He held the Jodrell Chair of Physiology at University College, London, from 1874 to 1882; the Waynflete Professorship at Oxford from 1883 to 1895, and the Regius Professorship of Medicine at the same University from 1895 until 1904. When he resigned this in consequence of failing health, he was succeeded by William Osler, whose claims he had strongly urged.

He was created a baronet in 1899. Elected F.R.S. in 1867, he was three times Croonian Lecturer to the Royal Society, and was Harveian Orator to the Royal College of Physicians in 1878, being awarded the Baly Medal in Physiology by that College in 1880, and a Royal Medal by the Royal Society in 1883. He was President of the British Association at its meeting at Nottingham in 1893. He died in 1905 at the age of 76.

A full account of his life is to be found in the Memoir which was commenced by his widow and completed after her death by his nephew and niece, Dr John Scott Haldane and Miss Elizabeth Haldane.

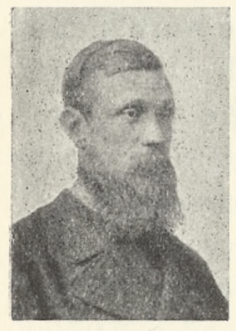

Michael Foster, who was born at Huntingdon on March 8th, 1836, must be regarded as the actual "begetter" of the Physiological Society, although the meeting at which it was founded was held in Burdon Sanderson's house. To Foster, Physiology in this country largely owes its present position. His judgment of character-although not unerring-was generally accurate, as is indicated by the young men he collected round him at Cambridge and who assisted in founding the school of Physiology there. A considerable number of these appear in the list of persons who were invited to constitute the Society - and two of them were amongst those who attended the foundation meeting. Foster seems to have been at pains to ascertain the bent of mind of any pupil who decided to work at Physiology, and to encourage him to pursue 
that branch of the subject for which he seemed best adapted. In this way, although he himself did not engage actively in research, he set Balfour to work on embryology, Gaskell on the vascular conditions relating to muscular activity, Langley on the functions of the sympathetic nervous system and their relation to the salivary glands, Newell Martin on problems connected with the mammalian heart, and Sheridan Lea on the chemistry of digestion ${ }^{1}$. Foster's success was, however, not due entirely to his influence over the younger Cambridge biologists, but quite as much to the power he had of influencing senior members of the University, who were not long in recognising that a prophet had arisen amongst them who would make the bones of biological science, which had become very dry in Cambridge, live again. These seniors were not by any means confined to Biology and their support must have given considerable encouragement to the new Prælector in his arduous task of building up a school of Physiology, and incidentally of Medicine, in the University. And he had, throughout, the loyal co-operation of Humphry.

It may be inferred from his achievements that Foster was a born organiser. Not the least of these achievements was the part he took in the formation of the Physiological Society. This was perhaps not a difficult task, and was rendered more easy by the fact that it received the support of such men as Huxley, Lewes, and Galton-none of them physiologists in the strict sense of the word, and all probably influenced in this connexion by Foster. Indeed most of the names which appear as the founders of the Society were, if not Foster's pupils, his close friends, and it was appropriate that he himself should propose the resolution forming the Society and should take the chair at the inaugural dinner.

Foster succeeded Huxley in the Biological Secretaryship of the Royal Society-an office he held from 1881 to 1903. (He had been a Fellow since 1872.) Working through the agency of the Physiological Society, he took a leading part in the establishment of the series of International Physiological Congresses-the first of which was held at Basel in 1889. Well known to all foreign physiologists, with most of whom he was on the most friendly terms, he was, at the Turin Congress in 1901, under the Presidency of Angelo Mosso, unanimously voted Honorary President

1 Whether George Romanes first obtained inspiration from Foster for his investigations on Medusae is less certain. The subject seems to have suggested itself to him whilst convalescing from typhoid at Nigg on the Cromarty Firth, where his family had a summer residence, and where the opportunities for such observations were considerable. 
of that and of all succeeding Congresses-a significant sign of his popularity in foreign physiological circles. In 1900 he was invited to deliver the Lane Lectures at San Francisco, and chose for his subject the History of Physiology - which was afterwards published in book form and has become the chief text-book on the History not only of Physiology but of Medicine in general. He was M.P. for the University of London from 1900 to 1906.

His Text-book of Physiology, which was first published in 1877, filled a real want; for at that time there was no book on the subject in the English language which could be described as in any sense authoritative. It rapidly went through three editions, each one an improvement on the other, and was justly popular, not only on account of the matter it contained, but still more by reason of the lucid and easy manner of exposition which was characteristic of the author. Later editions were less successful, partly because references to literature and even the names of discoverers were omitted, partly because the principle was adopted of delegating parts of the subject to others, so that the book became rather over-loaded with detail and was no longer the product of a single brain and therefore less suitable for use as a text-book.

A notable achievement was his establishment of the Journal of Physiology in 1878. Up to that time there was no Journal in the English language which was wholly devoted to Physiology. The Journal of Physiology filled a want which had been acutely felt, and immediately took a leading position as a medium of publication of original work.

The establishment of a Journal cannot be effected without pecuniary sacrifices-a difficulty which in this case was largely met by the liberality of a pupil and friend of Foster-A. G. D ew-Smith,

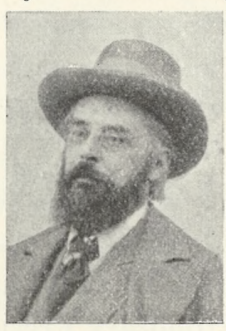
familiarly known to his friends as "Dew." DewSmith was a man of considerable fortune, of high culture and singularly good taste. He occupied until his marriage the rooms in Nevile's Court which appertained to Foster as a Fellow of Trinity. They were charmingly furnished by the occupant, the walls being adorned with examples of Rossetti, Burne-Jones and other favourite artists of that day. Dew-Smith was one of the original members of the Society and was present at the inaugural dinner.

Another important service rendered by Dew-Smith to Physiology, and indeed to Experimental Science in general, was the establish- 
ment of the Cambridge Scientific Instrument Co. which for many years was carried on almost entirely by him, although later he was aided in the management by Horace Darwin.

Even after it was started the running of the Journal presented financial difficulties, but eventually the Physiological Society was able effectively to subsidise it. In 1894 its management was taken over by Langley, who by thrifty administration and the increased pecuniary support of the Society converted it into a financial success. Since Langley's death in 1925 the Journal has become the property of the Society.

Michael Foster was of a genial disposition: cordial with all: very loyal to his friends. Partly on account of these personal qualities, partly by reason of his position as Secretary of the Royal Society, he exerted for many years an unusual influence in the scientific world. He built himself a house at Great Shelford, about three miles from Cambridge, on a bare spur of the Gog-Magog hills. A keen gardener and horticulturist, he surrounded it with a plantation and developed a charming garden in which he carried out experiments in hybridisation, by which his name is still well known in horticultural circles. He presided over the meeting of the British Association at Dover in 1889: on which occasion-for the first time-visits were exchanged between this and the corresponding French Association which met simultaneously at Boulogne. Few who witnessed it will readily forget the hearty manner in which Fostermore Gallico-saluted the French president on his arrival at Dover.

Foster was created K.C.B. in 1899, at the same time that a baronetcy was conferred on Sanderson. The double honour was celebrated by the Physiological Society by a dinner, which was held, at Foster's suggestion, at Richmond at the new Star and Garter, a poor successor of the famous old hostelry. It fell to the writer, as the next senior member, to occupy the chair and to propose the health of the two guests; their felicitous speeches in reply and the enthusiasm with which they were received more than made up for the deficiencies of the table.

Michael Foster died on June 28th, 1907. On that very day he had made an excellent speech at a meeting in London of the British Science Guild, exhibiting his activity to the end.

A detailed account of his career, sympathetically written by his successor, will be found in the Journal of Physiology, vol. 35, 1907. 


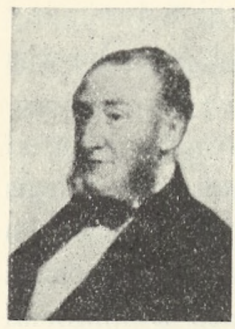

Frederick William Pavy-born in 1829-was 47 at the time of formation of the Society. He was therefore one of the oldest of the original members, and in the early years of the Society took a prominent part in its proceedings, being frequently invited to take the chair at the dinner meetings. He received his medical education at Guy's and after graduating at the London University in 1852, went to Paris and worked for a time in Bernard's laboratory. In 1853 he became Lecturer on Physiology at Guy's Hospital and also Assistant Physician. He retained the lectureship on Physiology until 1877 when he became full Physician and Lecturer on Medicine. He was elected Fellow of the Royal Society in 1863. In 1886 he was Harveian Orator at the Royal College of Physicians, and in 1901 received the Baly Medal for Physiology. His physiological work was chiefly on the chemical side, and related especially to the origin and destination of the blood-sugar, including, of course, work on the glycogen and sugar of the liver. He was led to take a different view from Claude Bernard on the subject of glycogenesis, since he found that his results as to the relative amount of sugar in the blood of the portal and hepatic veins did not agree with Bernard's figures. Although in the long run it has become apparent that Bernard's hypothesis was correct-to the effect that the sugar absorbed after a meal is mainly stored in the liver as glycogen and given out little by little as required by the tissues - it must be confessed that Pavy was right in arguing that the considerable excess of sugar in hepatic blood found by Bernard was probably the effect of the operation employed to collect the blood. Pavy's own experiments, in which this factor was eliminated, merely exhibited differences which were at that time within the limits of experimental error.

All Pavy's scientific work was a model of thoroughness and earned a deserved encomium from his fellow-physiologists. On the occasion of his eightieth birthday in 1909 he was presented by them with a silver rose-bowl inscribed "From the Physiological Society in token of affection and admiration," a striking indication of the regard he was held in by his younger colleagues. He died in 1911, continuing to work until the last ${ }^{1}$.

1 An appreciation of Pavy's work and of his personal character (the latter by his friend and colleague Hale-White) is to be found in the British Medical Journal, Sept. 30, 1911, pp. $777-8$. 


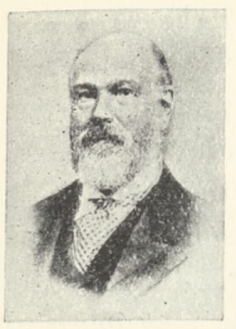

Philip Henry Pye-Smith (F.R.S., 1886) was born in 1840. He received his early education at Mill Hill School and at University College, but went to Guy's for his medical course. He graduated at the University of London, with high honours in many of the subjects of the examinations-including Physiology and Comparative Anatomy. Having spent some time studying in Vienna and Berlin, he was appointed in 1865 Lecturer on Comparative Anatomy at Guy's and also for four years filled the post of Demonstrator of Anatomy. In 1870 he became Assistant Physician and took up the teaching of Practical Physiology and Histology. In 1873 he was made Lecturer on Physiology jointly with Pavy, and from 1877 sole Lecturer on that subject, holding this appointment until 1883 when he became Physician to the Hospital and (the next year) Lecturer on Medicine. He retired in 1899, when he was made Consulting Physician. He delivered the Lumleian Lectures at the Royal College of Physicians in 1892 and a "most scholarly" Harveian Oration in 1893. He died in 1914 at the age of 74 .

Pye-Smith from the first took a keen interest in the foundation of the Physiological Society and was a frequent attendant at its meetings, often being in the chair. He was unusually cultured, being as much at home in the classics as in the natural sciences: a pleasant companion: sympathetic and kindly but endowed with a critical acumen which rendered his opinion on matters submitted to him of high value. The Society owes much to the advice and assistance rendered to it by him from its foundation until his death. His character is well described by his son (who was killed in the War) in lines written shortly after his father's death:

"Scholar, physician, courteous gentleman, beloved of all that knew him!"”

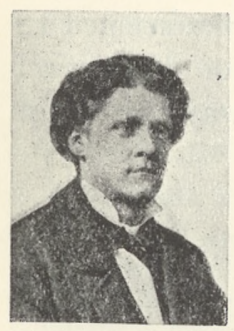

Arthur GamgeE, who was born in 1841, studied Medicine in Edinburgh, where he took his M.D. degree in 1862. In point of age amongst the original members of the Society he comes nearest to Pye-Smith, having been 35 at the time of its foundation. He was at first an extramural Lecturer on Physiology in Edinburgh and Physician to the Sick Children's Hospital. At this time he began researches on hæmoglobin and the action of nitrites thereon. In 1872 he was elected a Fellow of 
the Royal Society, at the age of 31. In 1902 he delivered the Croonian Lecture "On the Chemical and Physical properties of Hæmoglobin." In 1873 he was appointed the first Professor of Physiology in the Owens College, Manchester. To supply his own and other students with a textbook he translated Hermann's Lehrbuch, which was then the best elementary work on the subject. Besides teaching Physiology he was Physician to the Consumption Hospital in Manchester. In 1880 he published the first volume of an important work on Physiological Chemistry, but it was not until 1893 that the second volume made its appearance. In the early eighties Gamgee decided to devote himself entirely to medicine. Accordingly he removed to London and became Assistant Physician and Lecturer on Materia Medica at St George's Hospital. But before long ill-health compelled him to go abroad and he settled for some years in practice in Montreux. This he left in order to inspect and report on facilities for conducting researches in metabolism in European universities on behalf of the Carnegie Institute of Washington; but again took up practice in London when the report was finished. At this time he was working in Waller's Laboratory at the University of London with an apparatus for continuously recording the temperature of the human body: he was engaged in this investigation at the time of his death, which occurred whilst he was on a visit to Paris on March 29th, 1909.

In 1908 he represented the Royal Society at the celebration of the bicentenary of Albrecht von Haller at Bern, and presented an address drawn up by himself in excellent Latin and delivered in a fluent manner in the Italian style of pronunciation, producing a great impression on the assembled audience. Gamgee may certainly be described as a genius, but erratic. If he had kept to Physiology he might have been the first physiologist of the day - at any rate the first in biochemistry, which was the part of the subject he favoured. But he divided his energies between science and clinical medicine, and thus failed to achieve that high distinction in either, to which his intellectual powers seemed to entitle him. His simplicity of nature and kindliness of disposition endeared him to his friends and colleagues, who will always retain of him an affectionate memory ${ }^{1}$.

1 An excellent bibliography with a list of his published works is given in the Lancet, vol. 1, 1909, pp. 1141-45. 


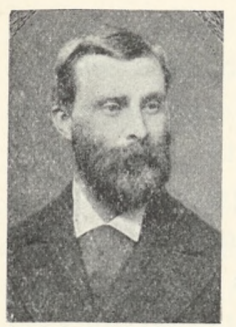

Thomas Lauder Brunton was born at Roxburgh in 1844 and graduated at the University of Edinburgh. He afterwards spent three years on the Continent (with Brücke and Rosenthal in Vienna, with Meyer in Berlin, with Kühne in Amsterdam, and with Ludwig in Leipzig) and at the end of his Wanderjähre was probably better acquainted with modern methods of Physiology and Pharmacology than anyone else in this country ${ }^{1}$.

He settled in London and was appointed Assistant Physician and Lecturer on Materia Medica at St Bartholomew's Hospital in 1871, eventually becoming full Physician there. He was elected F.R.S. in 1874 at the age of 30 . He devoted himself chiefly to Pharmacology. His early work was on Digitalis and the Nitrites. In 1885 was published his Text-book of Pharmacology and Therapeutics, which went through many editions. Although he continued to pursue research, he soon acquired a considerable practice and gradually gave up laboratory work: but he always remained helpful and sympathetic to other workers. $\mathrm{He}$ was knighted in 1900 and created a baronet in 1909. He died in 1916.

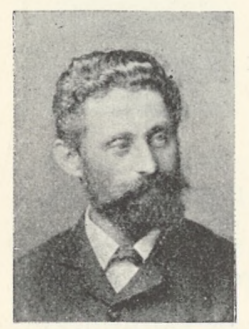

Edward Emanuel Klein was born at Essek in Slavonia in 1844. He worked as Privat-Docent in the laboratory of Stricker, the Professor of Pathology in Vienna, who edited a well-known Text-book of Histology which was translated into English. The articles were by different contributors: one or two by Stricker himself, a well-known one on blood by Rollett (in which he promulgated the stroma-theory of the structure of the red blood-corpuscle, as against the membrane-theory, which was originally enunciated by Schwann and has now again been adopted, in a modernised form, by most physiologists), one on the spleen by W. Müller, one on the lymphatics and serous membranes by v. Recklinghausen (who was the first to make use of the silver-nitrate method to show the structure of endothelial membranes), and so on. To this work Klein contributed several articles. Sanderson made Klein's acquaintance on a visit which the latter paid to this country in 1869, and being in need of a histologist to co-operate with him in his work on tubercle, invited

1 His assistance was, therefore, naturally invoked by Sanderson and Foster in the Handbook for the Physiological Laboratory, which they were preparing. This book was published in 1873 and was for a long time the only guide which English-speaking students had in their practical work. 
him to London as his research assistant, obtaining also for him remunerative work from the Local Government Board. Klein's services were engaged to write the Practical Histology for the Handbook for the Physiological Laboratory: this part was illustrated with magnificent drawings, some of them-especially those from silver preparations of the lymphatics of serous membranes-singularly elaborate. The cost of reproducing these as wood blocks - the zinc process had not then been invented-was enormous, and must have severely taxed the eyesight of the engraver. Klein worked at first at Sanderson's private laboratory in Howland Street and also at University College; later at the Brown Institution, where he was made Assistant Professor. Subsequently (1873 to 1892) he lectured on Histology and Physiology at St Bartholomew's Hospital, and in 1902 became Lecturer on Advanced Bacteriology there. In 1879 he published conjointly with Noble Smith an Atlas of Histology. He was elected F.R.S. in 1875. The evidence he gave before the Royal Commission on Vivisection in 1875 was unfortunate, for as a foreigner he failed to appreciate the dignity of such a Commission and treated the enquiry with contempt. It was many years before he lived down the impression which his statements produced; they certainly conveyed an erroneous idea of his actual opinions on the matter. He died in 1925 at the age of 80 : he had retired from active work for about ten years.

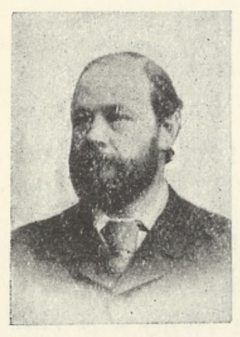

Gerald F. Yeo was a young Irishman who had succeeded William Rutherford in 1874 at King's College, Rutherford having been appointed Professor of the Institutes of Medicine in the University of Edinburgh. Yeo was born in 1845 at Howth near Dublin. He studied medicine in Trinity College, Dublin, graduating M.B. in 1867, and M.D. in 1871, studying further in Paris, Berlin and Vienna. He was at first Assistant Surgeon at King's College Hospital as well as Professor of Physiology, and had taken the F.R.C.S., but soon relinquished surgery and devoted himself to Physiology alone. He worked with Ferrier on the subject of cerebral localisation in monkeys, and published papers on various other subjects. He also wrote a Text-book of Physiology, which had at one time considerable vogue. He was elected F.R.S. in 1889.

Yeo was typically Irish-pleasant and friendly but impetuous, and unyielding in argument, steadfastly declining to be "convinced against his will." As a result of his possessing the diploma of F.R.C.S. he was 
almost constantly one of the examiners in Physiology for the Fellowship of the Royal College of Surgeons, since at this time the College refused to permit any but Fellows to hold an examinership. Nearly all the earlier records of the Physiological Society are in his handwriting, for it fell to his lot as the senior Secretary to keep the minutes. It must be admitted that he kept them but indifferent well. There is generally a very cursory account of the proceedings at the meetings: and in some cases no record of the business at all, although questions regarding the Vivisection Act were constantly under discussion during the first years of the Society's existence. But he was a favourite with everybody and was much missed when he retired from the Secretaryship and from the chair of Physiology at King's College, and went to live in Devonshire. He died in 1909 at the age of 64 .

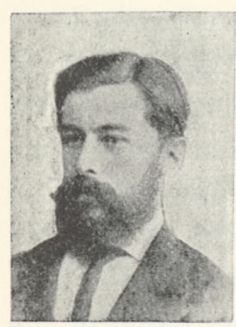

WALTER HolbRook GaSkell was born in 1847, and was therefore 29 years old in 1876. He had entered at Trinity College, Cambridge, in 1865 and took an honours degree in Mathematics. He then began medical studies, and was one of the first to benefit by the instruction of the new Prælector and to engage in original work in Physiology. In order to become familiar with modern methods he spent a year in the famous Institute at Leipzig presided over by Carl Ludwig, and there carried out an important research on the changes in the blood-vessels of muscle accompanying its contraction ${ }^{1}$.

On returning to Cambridge Gaskell set himself the task of investigating the causation of the contraction of the heart, which at that time was generally supposed to be produced through the activity of intracardiac ganglia and nerves. By a long series of experiments, made chiefly on the heart of the frog and tortoise, he was able to show in a convincing manner that the contraction arises in the muscular tissue itself, inde-

1 It was in many ways a peculiar advantage to work with Ludwig, not only on account of the genial personality of the Master, but by reason of the fact that the Leipziger physiologische Anstalt was, during the seventies of the nineteenth century, the centre of physiological activity in Europe. Ludwig attracted workers from all parts, so that those who had the privilege of conducting researches with him were also making the acquaintance of men who were in the future to become leaders in Physiology in their respective countries: e.g. Bowditch in America, Pavlov in Russia, Mosso, Luciani and Fano in Italy, Buchner in Bavaria, to mention but a few, and not forgetting the names of Ludwig's three chief assistants, Kronecker (for experimental physiology), Drechsel (for physiological chemistry) and Flechsig (for histology).

$\mathrm{PH}$. 
pendently of nerves or nerve-ganglia, and thus to establish the truth of the myogenic theory. This is the research with which Gaskell's name will always be intimately associated. It stands out as one of the landmarks of Physiology, although it was by no means the only piece of physiological work which he carried to a successful conclusion. He was led from the study of the course of the cardiac nerves to investigate the origin of vascular and visceral nerves in general, and was the first to give a clear account of the origin of the sympathetic from the spinal cord. His results were based both on anatomical and on physiological observations, and although they have been extended, they have never been called in question.

Somewhat later he was led to interest himself in a problem which is rather morphological than physiological, although he brought many physiological observations to bear upon it. The problem in question was no less than the origin of Vertebrata, which Gaskell believed to be from precursors belonging to an articulate type. According to him, the neural canal of the vertebrate, with its enlargement into the cerebral ventricles; represents the original alimentary canal of an articulate precursor, the ganglionic chain having grown around it and become evolved into the substance of the spinal cord and brain, whilst the present alimentary canal of the vertebrate is regarded as an entirely new formation, which developed with the retrogression of the original alimentary canal of the precursor. Gaskell brought forward a mass of evidence-embryological, comparative anatomical, histological and physiological-in support of his theory; but it has been ignored by most morphologists. His book, The Origin of Vertebrates, which gathered together the evidence he had been for years accumulating on the subject, was published in 1908 .

Like Foster, Gaskell was a keen gardener. He built himself a charmingly situated house at Great Shelford, near that of his chief, and surrounded it with a beautiful garden to which the members of the Society were generally invited on the occasion of the meetings at Cambridge. He acted for many years as Treasurer of the Society. He was a member of the second Royal Commission on Vivisection (1906), having been chosen as one of the representatives of Physiology. He became a Fellow of the Royal Society in 1882. In 1883 he was made Lecturer in Physiology in the University of Cambridge. He became a Fellow and Praelector in Natural Science at Trinity Hall in 1889. He received the Marshall Hall prize in 1888 for his work on the Nervous System, a Royal Medal of the Royal Society in 1889 and the Baly Medal of the Royal College of Physicians of London in 1895. He died in 1915. 


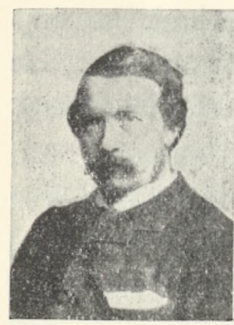

George John Romanes was born in 1848 at Kingston, Canada, where his father, the Rev. George Romanes, D.D., was then Professor of Greek; but the same year the family returned to England and settled in London. George Romanes was educated at a private school, from which in 1867 he went to Caius College, Cambridge. He took his degree in the Natural Sciences Tripos in 1870. Of all the young men who helped to launch the Society, Romanes was unquestionably the most brilliant. Possessed of outstanding intellectual power, he was both able and ready to uphold his opinions in matters relating to science, literature, art, politics, and even religion. He early came into prominence by his researches into the locomotor apparatus of Medusae (1873), and distinguished himself in the same year in an entirely different line with his Burney Prize essay on Christian Prayer considered in relation to the belief that the Almighty governs the world by general laws. In this essay he endeavours to meet the criticisms which had been brought against the efficacy of prayer by Tyndall, who suggested that it should be put to an experimental test in the wards of a hospital, and by Francis Galton, who argued that there was no evidence yielded by experience which seemed to render such efficacy probable. The essay is highly philosophical, and couched in orthodox phraseology: the fact that it was awarded the Burney prize is sufficient evidence of this. At one time in his Cambridge career Romanes had almost determined to take Holy Orders, but as his scientific education advanced, and his personal acquaintance with leading scientific men extended, his views on religion veered round to complete scepticism, or at least to pronounced agnosticism-which characterised most of the remainder of his life. But, towards its close, influenced probably by his familial and social environment, he again accepted the tenets of religious orthodoxy.

Up to 1873 he was working in Foster's laboratory at Cambridge; afterwards in Burdon Sanderson's at University College, when not engaged in conducting experiments on Medusae in Scotland. First Darwin's work, and later Darwin himself, had a great attraction for him, as he himself had for Darwin. He was a frequent visitor at Downe, and devised many experiments for the testing of some of the subsidiary theories which Darwin had enunciated, especially that known as "pangenesis." In 1892 he brought out the first, which proved also the last, volume of a book entitled Darwin and after Darwin, in which he deals at length with sexual isolation as contributing to, or even in certain instances supplanting, Darwin's 
theory of natural selection. It was in this year that he had the first symptoms of his fatal illness in the form of a retinal hæmorrhage. He died in May, 1894, of cerebral hæmorrhage, at the age of 46 . The story of his life has been given by his widow. Although, perhaps not unnaturally, tinged by a tendency to welcome his return to religious orthodoxy, it offers delightful reading; particularly is his correspondence with Darwin interesting.

With all his talents George Romanes had a simple lovable nature. He never concealed anything he might have in his mind, and even displayed in conversation an amount of self-appreciation of his own work and of his intellectual powers, which would have been characterised as vanity in most people, but in Romanes gave no offence, since it was a natural and unconscious part of his character. He was possessed of private means and did not need to undertake teaching for a livelihood, although as a lecturer he was eloquent, clear and convincing. At the time of the formation of the Physiological Society he was living in London. He was selected as one of the Secretaries of the new Society, and was afterwards appointed the first Treasurer. He became a Fellow of the Royal Society in 1879. He gave the Croonian Lecture "On the Locomotor Apparatus of Medusae" in 1875.

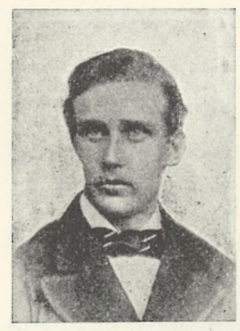

Henry Newell Martin, who was born at Newry in 1849 and died in Yorkshire in 1896, has already been mentioned as having accompanied Michael Foster in 1870 from University College, London, to the University of Cambridge. He won a scholarship at Christ's College, of which he became a Fellow in 1874. In 1873 he gained the first place in the Natural Sciences Tripos. At Cambridge, besides his more strictly physiological work, he aided the Prælector of Physiology to conduct a course of Elementary Biology; he had assisted in a similar course at South Kensington under Huxley.

When the Johns Hopkins University at Baltimore, Maryland, was founded, the Trustees sought for someone who would be able to develop Physiology in the contemplated Medical School. An application was accordingly made to Foster-probably through Huxley, who had been invited over to open the new Biological Department-and Foster decided that Newell Martin would be a competent person to undertake the task. Martin was accordingly appointed to the Professorship of Physiology in the new University in 1876, and set to work early in 1877. 
He was consequently not long connected intimately with the budding Physiological Society-although he retained his membership and his friendly relations with his colleagues in the old country. His importance in relation to the Society and to Physiology is that he formed a link connecting the physiologists of America with those of Great Britainsince his influence, as occupying the chair of Physiology in what was at that time the chief medical research centre of the States, was widespread. Indeed many of the older American physiologists have received their training either directly or indirectly from Newell Martin, who himself handed on the teaching he had received from Sharpey and Foster.

Newell Martin was the first to devise a method for investigating the isolated mammalian heart by means of the heart-lung preparation (which was afterwards to be so successfully developed by Starling), and the influence of temperature and other conditions upon it. On this subject he gave the Croonian Lecture in 1883. He was the author of numerous papers on Physiology and of some text-books - amongst others one on Practical Biology, which he brought out in conjunction with Huxley.

He resigned his chair in 1893 owing to ill-health, and returned to this country. As Michael Foster, in an obituary notice in the Proceedings of the Royal Society, remarked, "he has left behind him a memory which will not soon pass away." This was thirty odd years ago, and there are now not many British physiologists who knew him personally: those who did will certainly agree with this sentiment.

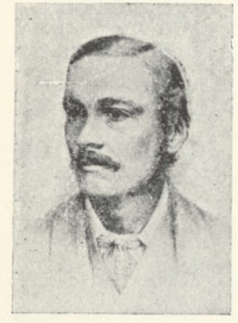

Francis Mattland Balfour was the third son of James Maitland Balfour of Whittingehame and of Lady Blanche, daughter of the second Marquis of Salisbury. Arthur Balfour, now the Earl of Balfour, is his eldest brother. Frank was born in Edinburgh in 1851. His father died when he was quite young. He went to Harrow, and was fortunate to find there in one of the masters-George Griffith, well known as the Acting Secretary for many years of the British Association-encouragement in the pursuit of science. It is curious to read that when biological subjects were discussed at the school Scientific Society, Frank Balfour came forward as an uncompromising opponent of Darwinism, "little thinking that in after life his chief work would be to develop and illustrate the doctrine of evolution ${ }^{1}$."

1 M. Foster, obituary notice in the Introduction to the Collected Works published in 1885. 
In 1870 he entered Trinity College, Cambridge. Here he came under the notice of Michael Foster, who had just been made Prælector of Physiology: and who, with his fellow-examiners, at the scholarship examination the following Easter, had no difficulty in awarding the first place to Balfour. He soon began to make his mark at Cambridge. In the Natural Sciences Tripos in December 1873 he was second in order of merit: the first place being taken by his friend Newell Martin. Even before the Tripos he had, on the suggestion and with the encouragement of Michael Foster, begun investigations in embryology, commencing with the chick: the result of this work was published in the Quarterly Journal of Microscopical Science for July 1873. After taking his degree he spent six months at the Zoological Station in Naples, choosing as the subject of investigation the development of Elasmobranchs. His observations on this subject proved of great importance: they were published in a preliminary form at the British Association Meeting at Belfast in 1874 and in the Quarterly Journal of Microscopical Science in October of the same year. On the results of this work he was elected, on the advice of Huxley, to a Science Fellowship at Trinity. In 1875 he began lecturing on Embryology, and in the following year, in conjunction with Milnes Marshall, gave a systematic course on Animal Morphology as well. In 1878 his researches on the development of Elasmobranch fishes were published in the form of a monograph in one volume. The same year, at the early age of 27 , he was elected to the Fellowship of the Royal Society. In 1880 and 1881 appeared his Comparative Embryology. This was a stupendous piece of work and occupied him for the best part of three years. By this time he had become the recognised authority on the subject of Embryology and in 1881 received a Royal Medal for his work. The same year he was chosen as one of the General Secretaries of the British Association. In the following year he received a pressing invitation to go to Edinburgh in succession to Sir Wyville Thomson, but decided to remain at Cambridge-with which and with London he had many and close personal ties. A new Professorship of Animal Morphology was now instituted specially for him at Cambridge and steps were taken to build him a laboratory. But in the summer of this very year there came to his colleagues and friends, like a bolt from the blue, the announcement of his death in an Alpine accident, which occurred on July 19th in an ascent of the Aiguille Blanche from Courmayeur. His body was brought home, and is buried at Whittingehame. It is difficult to give an idea of the distress and even consternation which was caused at the news. In the words of Michael 
Foster, "the same lines came to the lips of all of us, so fittingly did Milton's words seem to speak our loss and grief-

For Lycidas is dead, dead ere his prime,

Young Lycidas and hath not left his peer."

Tall and well built, possessing an open countenance, with deep-set expressive eyes, a gentle demeanour, a remarkable strength of character and firmness in holding opinions, although modest in expressing them; a pleasant companion; exhibiting perfect courtesy and a ready wit-all these attributes endeared him to his friends. The Physiological Society may be proud that he was enrolled amongst its earliest members.

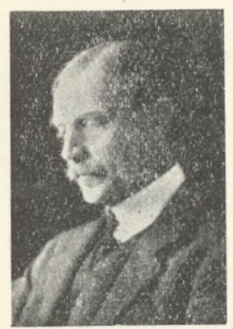

John Newport Langley was another of the discoveries of Michael Foster. Born in 1852 at Newbury, he entered St John's College, Cambridge in 1871. He at first studied Mathematics and History, but presently changed his plans and devoted himself to Natural Science, obtaining a first class in the Natural Sciences Tripos in 1874. In 1877 he was elected to a Fellowship at Trinity. At first under Foster's influence, but soon in entire independence, he began his physiological work with a study of the action of pilocarpine on the heart (1875) and continued his investigations into the changes produced in secretions under the influence of nerves and drugs, which eventually led him to attempt the elucidation of the origin and course of the sympathetic and parasympathetic fibres (autonomic nervous system), a subject to which his colleague Walter Gaskell had already made important contributions. Gaskell's work on the subject was mostly of a morphological nature, Langley's was based on the results of physiological experiment. In the course of his researches on the salivary glands he not only investigated the functional activity of these organs, but added many new observations regarding their structure. He also made important contributions to the physiology of the central nervous system and of peripheral nerves and muscles. In all his work, whether on glands or blood vessels or muscle or nerves, Langley rarely relied upon the production of a graphic record. He was satisfied to set down exactly what he could observe with the unassisted eye. In this respect he resembled Claude Bernard, and differed from most physiologists. But the accuracy of his observations, like those of Bernard, was such that his statements of fact were never called in question. 
He was elected F.R.S. in 1883: in 1892 he received a Royal Medal, in 1903 the Baly Medal of the Royal College of Physicians, and in 1912 the Retzius Medal from Sweden. He succeeded Michael Foster in the chair of Physiology at Cambridge in 1903. He died on November 5th, 1925 , at the age of 73 . But no one would have supposed that the alert well-set man with clear-cut features, greying hair, and steel-blue eyes, still so capable of strenuous work, had nearly attained that age. Langley's scientific career and work have so recently been the subject of an article in this Journal by Sir Walter Fletcher (March 1926) that it is not necessary to recapitulate what has there been given. Suffice it to say that from its formation in 1876 until his death there was no more active participator in the work of the Physiological Society than John Newport Langley.

\section{FURTHER HISTORY OF THE SOCIETY}

Resuming now the history of the Society from May 26th, 1876, the date of the inaugural meeting, it appears from the Minute Book that the first ordinary meeting was not held until November 9th of the year of foundation, although, no doubt, the Committee of the Society was meanwhile engaged in the examination of the Government Bill.

November 9th, 1876 (at 85 Jermyn Street). The first business recorded in the minutes is a resolution dealing with the certificate required for the demonstration of experiments for the purpose of instruction. The opinion was expressed that the description of experiments to be shown should be worded "in as general and comprehensive manner as possible."

The second business item is a resolution "that the Society should recommend to the Scientific Grants Committee of the Royal Society such researches in Physiology as it might be thought desirable and appoint a special Committee, with Dr Pye-Smith as Secretary, to report regarding the matter."

The members present at this first ordinary meeting were G. H. Lewes (in the chair), Balfour, Dew-Smith, Gamgee, Gaskell, Langley, Humphry, McCarthy, Pavy, Power, Brunton, Ferrier, Foster, Pye-Smith, Sanderson, Yeo, Schäfer. Three visitors are entered in the minutes as follows: "Mr Lea introduced by Dr Foster, Mr Vine introduced by Mr Langley, Mr Bruce introduced by Dr Sanderson ${ }^{1 . "}$

1 In nearly all cases the names of those attending have been transcribed exactly as they are entered in the minutes. They are sometimes misspelt and are never in alphabetical or any other recognisable order. In most cases I have attempted to give an indication of 


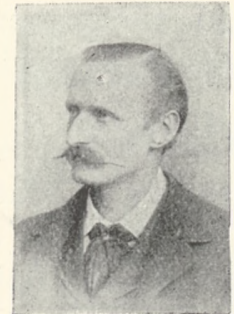

Mr Lea is Arthur Sheridan Lea (F.R.S. 1890) who was born in 1853. He obtained a First Class in the Natural Sciences Tripos in 1875. He entered Trinity College, Cambridge, but afterwards became a Fellow of Caius College, and Lecturer on Physiological Chemistry. His chief researches were on digestive and other ferments. He was the author of the part of Foster's Text-book of Physiology dealing with Physiological Chemistry, but is probably best known for his work on the pancreas with Kühne. He joined the Society in 1877 and for many years - until his health broke down-he was a regular attendant at its meetings. He died in 1915, after a long illness, much regretted by his colleagues and friends.

Mr Vine (sic) is Sydney Howard Vines (F.R.S. 1885), the distinguished botanist, at that time a Fellow of Christ's College, Cambridge: subsequently Sherardian Professor of Botany in the University of Oxford.

Mr Bruce is probably Dr Mitchell Bruce, who was at that time Assistant Physician to Charing Cross Hospital and Lecturer on Physiology in the Medical School attached to the Hospital, and is now Consulting Physician both to that Hospital and to the Brompton Hospital for Consumption.

This first ordinary meeting and all other meetings during the next two or three years were held at a hotel in Jermyn Street ${ }^{1}$, where the Secretary (Yeo) engaged a room for the Society to dine. It must be remembered that the Society was founded as a dining club (see p. 10); so that the members, who all knew each other well, could discuss in an informal manner subjects which might concern them as physiologists. That the number of members of the Society was by the original rules limited to forty, of whom not more than half the number were ever likely to be present at one time, also tended to preserve for it the character of a dining club. Even at the present day, when the Society numbers about 400 members and has ceased to be a dining club, it carries on the tradition by frequent dinner meetings, and although there are meetings

the position and in some cases of the career of each individual. In many identification has been difficult, in some impossible; partly owing to misspelling in the minutes, partly because often only the surname has been given, and this has furnished no trustworthy clue to identification.

1 The Waterloo Hotel, 85 Jermyn Street. It has long disappeared. It was here that Arthur Orton, "The Tichborne Claimant," had for some time his headquarters. 
for scientific purposes alone, its non-scientific and administrative business is generally conducted after the dinner meetings, as provided for in the original rules of the Society.

In 1879 the meetings began to be held at the Café Monico in Tichborne Street instead of at the Waterloo Hotel, and continued to be held at London restaurants, with an occasional excursion to the "Star and Garter" at Richmond, a hostelry much beloved for its old associations by Michael Foster. With the establishment of the scientific meetings it became customary for the dinner to be held in the refectory belonging to the institution visited, or, at Cambridge and Oxford, in one of the Combination or Common Rooms.

December 14th, 1876 (at 85 Jermyn Street). At this the second ordinary meeting Dr T. Lauder Brunton was in the chair. Other members present were Pavy, Ferrier, Thiselton Dyer, Foster, Schäfer, Yeo, Pye-Smith, Klein, McCarthy, Lewes, Gaskell, Romanes, Langley and Dew-Smith. The visitors were Professor Allman introduced by Dyer, Sir Joseph Fayrer by Brunton, Mr Henry Nottidge Moseley by Klein, and Mr Butler by Langley.

Professor G. J. Allman (F.R.S. 1854) was at first Regius Professor of Botany in Trinity College, Dublin, but from 1856 to 1870 occupied the Regius Chair of Natural History in the University of Edinburgh. He was President of the Linnæan Society in 1874 and of the British Association in 1879. He died in 1898 at the age of 86.

Sir Joseph Fayrer, Bart. (F.R.S. 1876), was an eminent surgeon attached to the Indian Army, who greatly distinguished himself in the Mutiny at the Siege of Lucknow. He was a fellow-student and intimate friend of Huxley. He published important memoirs on the poisonous snakes of India, and worked with Brunton on the action of snake venom. He died in 1907 at the age of 83 .

Mr Henry Nottidge Moseley (F.R.S. 1880), naturalist of the "Challenger" Expedition, was a Fellow of Exeter College, Oxford. He died in 1888 at a comparatively early age. He was the father of the brilliant young physicist, H. G. J. Moseley, who was born in 1887 and was killed at Suvla Bay in August 1915; his premature death is universally considered to have been one of the most calamitous results of the Great War ${ }^{1}$.

At this meeting the Committee appointed to advise regarding Govern-

1 See obituary notice by Sir Ernest Rutherford, in Proc. Roy. Soc. A, vol. xcIII, 1917. 
ment grants presented its report. It may be of interest to give a list of the applications, which were as follows:

Mr Langley: The action of the sympathetic on the submaxillary gland.

$£ 30$.

Mr Romanes: Observations on the locomotor system of the Medusæ.

Professor McKendrick: Respiration in fishes.

$£ 100$.

Professor Gerald Yeo: The relation between the duration of latency and that of contraction of various kinds of muscle. $\quad £ 30$.

Professor Arthur Gamgee: The physiological relations of the elementary bodies.

Professor Schäfer: For the wages of an assistant in his histological and embryological investigations.

(Annually) £50.

Professor Ray Lankester: Personal. To recompense him for the time devoted to researches into $(a)$ the Embryology of Invertebrata; $(b)$ the natural history of the organisms concerned in putrefaction.

(Annually) £200.

Professor T. Lauder Brunton: Physiology of certain compounds of nitrogen and the action of certain poisons. And for constructing an apparatus for administering chloroform to animals. $£ 80$.

The Committee presented a reasoned report. It shied at the applications for annual grants, and doubted the ability of Professor Lankester to carry on such extensive researches simultaneously. But the Society eventually agreed to support all the applications.

January 11th, 1877 (at 85 Jermyn Street). At this, the third meeting, Dr Burdon Sanderson was in the chair. Seven other members were present, namely, Pavy, Lankester, Schäfer, Romanes, Galton, Pye-Smith and Yeo, and two guests, namely, Dr Gayet of Lyons, introduced by Sanderson, and Mr Hart ${ }^{1}$, introduced by Yeo.

The applications to the Government Grant Committee were again considered one by one, and the recommendations made at the previous meeting were endorsed, and ordered to be transmitted to the Secretary of the Royal Society.

February 15th, 1877 (at 85 Jermyn Street). At the fourth meeting Dr Ferrier was in the chair. The following members were also present:

1 Probably Mr Ernest Hart (see p. 47). 
Sanderson, Romanes, Caton, Dew-Smith, Balfour, Yule, Pye-Smith, Dyer and Yeo. Mr Robert Lawson was introduced as a guest by Dr Ferrier. Only formal business was transacted.

The minutes of this meeting are signed

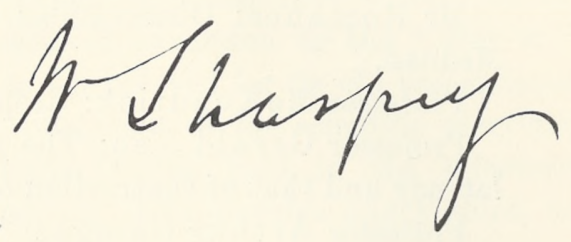

March 15th, 1877 (at 85 Jermyn Street). At this meeting, besides Professor Sharpey, the chairman, the following were present: McCarthy, McDonnell, Pye-Smith, Sanderson, Schäfer and Yeo. A committee was appointed, with Pye-Smith as Secretary, to consider a complaint from one of the members of the Society concerning the working of the Act 39 and 40 Vict. cap. 77.

The minutes are signed
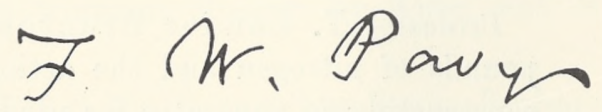

May 10th, 1877 (at 85 Jermyn Street). This was the first Annual Meeting. Dr Pavy was in the chair. The following members were also present: Lauder Brunton, Ferrier, Lewes, Gaskell, Romanes, Schäfer, Dew-Smith, Dyer, Lankester, Pye-Smith, Sanderson, Marshall, Sharpey, Foster, Gamgee, Power, Klein and Yeo. The guests were Dr Putnam, introduced by Brunton, and Dr Coats, introduced by Ferrier.

Dr Putnam was probably the well-known American publisher.

Dr Joseph Coats was a distinguished pathologist, Professor in Glasgow University from 1894 until his death in 1899 at the age of 55. He was President of the Pathological Society in 1876 and of the Medico-Chirurgical Society in 1891.

The following were elected members: W. H. Allchin (London), G. F. Bettany (Cambridge), J. C. Ewart (London), A. Sheridan Lea, Henry Nottidge Moseley, William Stirling (Edinburgh), Sydney Howard Vines.

Dr Allchin, afterwards Sir William Allchin, was a former pupil of Sharpey and assistant to Michael Foster whilst the latter was Professor of Practical Physiology at University College. Subsequently he became lecturer on Physiology and physician to 
Westminster Hospital. He was President of the Medical Society of London in 1901 and was Harveian Orator of the Royal College of Physicians in 1903. He died in 1911.

Dr James Cossar Ewart (F.R.S. 1893) was at this time Curator of the Anatomical Museum at University College. He afterwards became Professor of Natural History in the University of Aberdeen, and since 1882 has held the same post in the University of Edinburgh.

Dr William Stirling was at the time Assistant to Professor Rutherford in Edinburgh. Later he became Professor of Physiology in Aberdeen and subsequently occupied a similar position in the Owens College, Manchester.

The following were elected on the first Committee: T. L. Brunton, Michael Foster, G. H. Lewes, P. H. Pye-Smith, J. Burdon Sanderson, Henry Power and E. A. Schäfer. And as Secretaries: George J. Romanes, Gerald F. Yeo.

Dr Pye-Smith submitted the report of the committee on the working of the Vivisection Act, instancing cases in which certificates had been suspended or refused. It was resolved to instruct the Secretaries to submit to the General Medical Council a statement of the facts and to express the hope that they would take such action as might be expedient.

The minutes of this meeting are signed

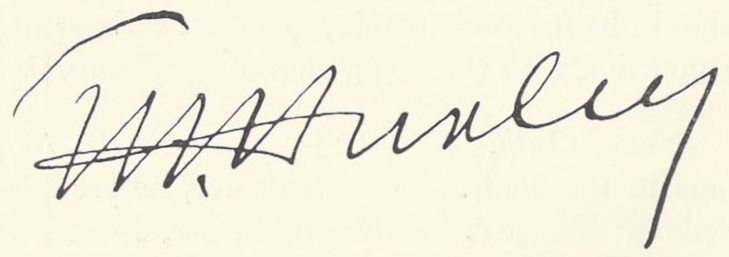

November 8th, 1877 (at 85 Jermyn Street). At this meeting Professor Huxley was in the chair, and the other members present were Sharpey, Sanderson, Pavy, Power, Brunton, McCarthy, Pye-Smith, Foster, Allchin, Ewart, Klein, Yeo, Schäfer, Langley, Lea, Vines, Bettany, Yule and Romanes, besides two guests, Messrs Bullar and Simpson.

The method of examination in Physiology for the membership of the Royal College of Surgeons was discussed at some length, but no resolution was adopted.

December 13th, 1877 (at 85 Jermyn Street). The next meeting was presided over by Professor Burdon Sanderson, the following members 
being also present: Sharpey, Power, Brunton, McCarthy, Ferrier, Yeo, Schäfer, and Romanes. Two guests are entered, namely, Dr Allen Thomson, introduced by Dr Sharpey, and Mr Geddes, introduced by $\mathrm{Mr}$ Shafer (sic).

Dr Allen Thomson, F.R.S., was a distinguished anatomist and embryologist, at that time Professor of Anatomy in Glasgow. He had previously been Professor of Physiology in Edinburgh, and was a life-long friend of Sharpey. He was one of the editors of Quain's Anatomy. He joined the Society in 1878 and was elected an Honorary Member in 1882. He died in 1884.

Mr Patrick Geddes was until recently Professor of Botany in Dundee. He had been a demonstrator in Professor Huxley's class of Practical Biology at South Kensington, and had transferred to University College, where he was Sharpey Scholar. Of late years he has become distinguished as a planner of cities, in India and elsewhere.

A committee was appointed to bring before the Home Secretary the effect of impediments thrown in the way of therapeutic experiment by the administration of the Vivisection Act, the committee consisting of Sharpey, Sanderson, Brunton, Gamgee, Foster, Pye-Smith and one of the Secretaries. This committee reported at the following meeting and recommended that the assistance of the Presidents of the Royal Colleges should be invoked to bring pressure to bear on the Home Secretary in connexion with the suspension of Dr Brunton's certificate.

January 10th, 1878 (at 85 Jermyn Street). At this meeting Dr Gamgee was in the chair. The attendance, as recorded in the minutes, is as follows: Sharpey, Sanderson, Foster, Lewes, Power, Ferrier, Brunton, Pye-Smith, Klein, Langley, Ewart, Romanes, Schaefer, Dyer, Lancaster (sic), Yule and Yeo.

It was decided to counteract the anti-vivisection agitation by the issue of publications or otherwise, as the Committee might decide, and authorisation was given to it to incur such expense as might be necessary.

February 14th, 1878 (at 85 Jermyn Street). At this meeting Mr Schäfer was in the chair and other members present were Brunton, Bettany, Klein, Lea, Pye-Smith, Sanderson, Vines and Yeo. A noteworthy visitor was Mr Sims Reeves, introduced by Mr Lea-but what attraction brought the great tenor to a meeting of the Society does not appear, nor is it recorded whether he obliged the company with a song. Other 
visitors were Mr Page, introduced by Mr Schäfer, Mr Pye, introduced by Dr Brunton, and Dr Lambe, introduced by Mr Vines.

Mr F. J. M. Page was Sanderson's research assistant. He also conducted the course of Practical Physiological Chemistry at University College, and later lectured on Chemical Physiology at the London Hospital Medical School. He joined the Society in 1878. He died in 1907.

Dr Brunton informed the meeting that the Home Secretary had removed every restriction on his certificates and that therefore the action recommended at the meeting in December need not be taken.

March 14th, 1878 (at 85 Jermyn Street). The minutes of this meeting are of considerable interest. There were present Dr Robert McDonnell (in the chair), Caton, Foster, Sanderson, Ewart, Dyer, Lankaster (sic), Romanes and Yeo. And as guests Mr Ernest Hart, introduced by Foster, and Dr Howard (of New York), introduced by Yeo.

Dr Robert McDonnell (F.R.S. 1865) was an eminent Dublin surgeon, who had published papers dealing with the physiology of the liver. He filled the offices of President of the Royal College of Surgeons in Ireland and President of the Royal Academy of Medicine. He died in 1889 at the age of 61 .

Mr Ernest Hart, afterwards Sir Ernest Hart, was for many years the editor of the British Medical Journal.

Dr Howard was the inventor of the method of artificial respiration known by his name.

It was reported that copies of Hermann's pamphlet and McDonnell's address On the necessity of animal experimentation had been procured, and it was agreed that "steps be taken for the distribution of them and other instructive essays on the subject."

A letter was read from Professor McKendrick pointing out the inconvenience to Scotch members of meetings on Thursdays. It was agreed to hold the next Annual Meeting on a Saturday and that another Saturday meeting should be held in October.

The Secretaries were directed to invite Dr Pye-Smith to co-operate with them in sending a letter to the Société de Biologie, expressing sympathy at the loss of their President, Claude Bernard. A copy of the letter, floridly worded (doubtless by Yeo; it is written from his club), is in the Minute Book, but the date has been omitted. It asks that the 
Physiological Society may be permitted to contribute to any memorial raised to Bernard.

It was determined at this meeting that the Committee take into their immediate consideration the best means of celebrating April 1st, 1878, being the tercentenary of the birth of William Harvey. But there is no record that this resolution was acted upon ${ }^{1}$.

May 18th, 1878 (at 85 Jermyn Street). This was the second Annual General Meeting of the Society. It was held at the Waterloo Hotel. The minutes relating to attendance read as follows: "Were presentMr Galton in the chair, Drs Sanderson, Foster, McDonnell, McKendrick, Gamgee, Pavy, Power, Brunton, Ferrier, Klein, Pye-Smith, and Messrs McCarthy, Schaefer, Allchin, Ewart, Gaskell, Lea, Langley, Yeo. Visitors: The President Coll. Phys. Dublin, introduced by Mr Yeo, Dr Coats, introduced by Dr Brunton, Professor Dewar, introduced by Dr McKendrick."

Professor Dewar, afterwards Sir James Dewar, F.R.S., is the celebrated chemist, successor to Tyndall at the Royal Institution. He died in 1925.

At this meeting the date of the Annual Meeting was altered from May to October. It was further resolved that the number of ordinary members should be increased from "forty" to "fifty."

The ballot for members of Committee was then held, the following being appointed: Brunton, Ferrier, Foster, Pavy, Power, Pye-Smith and Sanderson. The election of new members was postponed to October. This minute is signed "P. H. Pye-Smith Oct. 12. 78."

The record of the minutes of the meeting of October 12th, 1878, which was to be the next Annual Meeting of the Society, is not to be found in the Minute Book, nor is there any record of the meeting in November, which was presumably held, and should have been signed by Dr Ferrier, who presided at the meeting of December 12th. Six pages of the Minute Book have been cut out between the record of May 18th, 1878, and that of December 12th, 1878. We have therefore no names of those elected as members in October. But from other evidence it would appear that they probably included F. J. M. Page, J. Priestley (of Manchester), and Allen Thomson. A similar incident is repeated in 1886 (p. 83).

1 The tercentenary was, however, celebrated by a dinner at Caius College, Cambridge (Harvey's College), to which many members of the Society were invited. 
December 12th, 1878 (at 85 Jermyn Street). At this meeting Dr Ferrier was in the chair; there were eleven other members, viz. Sanderson, Brunton, Pye-Smith, Lankester, Francis Darwin, Dyer, Dew-Smith, Romanes, Page and Yeo, and three visitors, viz. Mr Craik, introduced by Brunton, Mr Cheyne, by Yeo, and Mr Liversidge, by Dew-Smith.

Mr Francis Darwin (F.R.S. 1882), one of the original members of the Society, was the third son of Charles Darwin, born at Downe in 1848. He obtained a first class in the Natural Sciences Tripos in 1870 and afterwards studied medicine in London, and graduated M.B. but never practised. He was Lecturer and Reader in Botany in Cambridge from 1884 to 1904: was President of the British Association in 1908 and was knighted in 1913. He died in 1924.

Mr Craik is probably Mr Henry Craik, afterwards Sir Henry Craik, Bt., M.P. He died only this year (1927).

Mr Cheyne is now Sir William Watson Cheyne, Bart., F.R.S.

Mr Liversidge is Professor A. Liversidge (F.R.S., 1882) who was Professor of Chemistry in Sydney from 1873 to 1908. He died 26th September, 1927.

A resolution was passed recording regret at the death of $\mathrm{Mr}$ George Henry Lewes, "one of the Society's original members."

The minutes are signed "Francis Galton."

It was resolved to hold the meetings of October, January and May on Saturdays and the other meetings on Thursdays.

A new phase in the history of the Society now begins, although it is not yet seen in a developed form. A special afternoon meeting: was called at King's College, London, on January 12th, 1879, to hear an address by Professor Arthur Gamgee on "Old and new experiments. relating to Fibrin Ferments," with a demonstration of the "rapid coagulating action of a solution made by extracting washed blood clots with 8 p.c. $\mathrm{NaCl}$ solution" (Andrew Buchanan's solution). Eight members were present and one visitor.

January 12th, 1879 (at 85 Jermyn Street). The regular dinner meeting of the Society was held the same evening at the Waterloo Hotel, with Mr Galton in the chair. The other members present were Sanderson, Gamgee, Sheridan Lea, Dew-Smith, Romanes, Priestley, Page and Yeo, and one visitor, Dr Wolsely. The Secretary read a letter, which is preserved in the minutes, from the secretary of the Sociéte de Biologie, acknowledging the receipt from the Physiological Society of $£ 80$ for the 
Claude Bernard Memorial. Evidently thus early in its career the Society was in a sound financial position.

February 13th, 1879 (at 85 Jermyn Street). At this meeting, with $\mathrm{Mr}$ Henry Power in the chair, the attendance was small, viz. Sanderson, Ferrier, Allchin, F. Darwin, Dew-Smith, Dyer, Lankester, Moseley and Yeo. No business was transacted.

March 14th, 18791. At this meeting, with Thiselton-Dyer in the chair, the other members present were Foster, Pye-Smith, Brunton, Ferrier, Dew-Smith and Yeo, and one visitor, Mr Harrison Cripps, the surgeon, introduced by Brunton.

It was proposed by Dr Foster and carried "That the meeting in May be held, as far as business [scientific, no doubt] is concerned, at King's College, and as far as other matters [gastronomic, no doubt] are concerned, at Richmond ${ }^{2}$."

May 10th, 1879 (at Richmond). This meeting was held at the Castle Hotel, Richmond, with Dr Sanderson in the chair: the other members present were Caton, Brunton, Pye-Smith, Foster, Balfour, Langley, Allchin, Lea, Dew-Smith, McCarthy, Power, Thiselton-Dyer, Page, Romanes and Yeo-and two visitors, Dr Timothy Lewis (who discovered Filaria sanguinis hominis), introduced by Brunton, and Dr Tschirjew (Russia), introduced by Yeo.

October 11th, 1879 (at the Café Monico, 15 Tichborne Street). This was the fourth Annual Meeting. Mr John Marshall was in the chair. The following members were also present: Sanderson, Foster, Ferrier, Pye-Smith, Thomson, Page, Ewart, Vines, Lea, Dew-Smith, McCarthy, Allchin, Dyer, Moseley, Lankester and $\mathrm{Yeo}$, and four visitors, namely, $\mathrm{Mr}$ Alexander (probably the eminent Manchester metaphysician), introduced by Moseley: Mr Parker (Comparative Anatomist), introduced by Ewart: Mr Stewart (probably Charles Stewart, the Hunterian Professor at the Royal College of Surgeons), by Lankester: and Mr Groves, by Yeo. The Committee for the ensuing year was elected as follows: Ferrier, Foster, Gamgee, Power, Pye-Smith and Burdon Sanderson, with Romanes and Yeo as Secretaries. One new member was elected, namely, Mr Walter Pye.

Mr J. W. Groves was Yeo's Assistant at King's College, where he taught Histology. He joined the Society in 1880. Groves had

1 Place of meeting not stated but probably 85 Jermyn Street.

2 Apparently there was no scientific business, for only the gastronomic meeting is recorded. 
been Secretary of the Medical Microscopical Society, which was established some time before, and had a few years of unobtrusive but useful existence. The formation of the Physiological Society, which included Histology amongst the subjects dealt with, rendered the continuance of a special Society unnecessary.

Mr Walter Pye was a Cambridge graduate, working in Foster's laboratory.

November 13th, 1879 (at the Café Monico). This meeting is the smallest yet recorded, consisting only of Dr Pavy in the chair, with Dew-Smith, Romanes and $\mathrm{Yeo}$.

December 11th, 1879 (at the Café Monico). At the next meeting $\mathrm{Mr}$ Galton was in the chair, with the following attendance: Brunton, Klein, Lea, McCarthy, Romanes, Pye, Power and Yeo, and three guests, Messrs Meade Smith, J. F. Bullar and Mansell Moullin.

Up to this time the minutes have been in Yeo's handwriting but the next three are written by Romanes.

January 8th, 1880 (at the Café Monico). At this meeting Mr J. N. Langley was in the chair. Only four other members were present, namely: Lee (sic), Pye, Romanes and Yeo, with one guest, Dr Flood, introduced by Romanes. It was resolved that in future "gratuities to the waiters for attendance at the dinners should be paid by the Secretaries out of the Society's funds, in order that members dining with the Society should not be expected to pay anything additional to the cost of their dinners ${ }^{1} . "$

February 12th, 1880 (at the Café Monico). At this meeting, with Dr Foster in the chair, seven other members were present, namely, Burdon Sanderson, Dew-Smith, Pye-Smith, Page, Yeo, Schäfer and Romanes. No business is recorded.

March 11th, 1880 (at the Café Monico). Mr F. M. Balfour was in the chair, and other members present were Sanderson, Yeo, Gaskell, Allchin, Bettany, Dew-Smith, McCarthy and Romanes.

McCarthy introduced as a guest Mr Bowkett "who exhibited to the meeting an ingenious piece of apparatus for recording diurnal variations of temperature of the animal body."

"It was resolved that a meeting should be held at Richmond,

1 This custom has continued to the present day, in spite of resolutions to the contrary having been more than once adopted. 
Surry (sic) on the 3rd of June, 1880, which should be regarded as an adjournment of the meeting previously arranged for May 8th."

June $3 r d, 1880$ (at Richmond). A meeting was accordingly held on that date at the Star and Garter with Dr Foster in the chair. The following members were also present: Pavy, Power, Langley, Dew-Smith, Lea, Schäfer, Moseley, J. Priestley, Pye and Romanes, and three guests, namely, Mr Coutts Trotter, introduced by Dew-Smith, Dr Young, introduced by Priestley, and Mr Bird, introduced by Moseley.

Mr Coutts Trotter was an influential Fellow (Vice-Master) of Trinity; a friend and supporter of Foster at Cambridge. He endowed the valuable Coutts Trotter Scholarship for Physiology or Physics, which has been held by many members of the Society, who have owed to it their first opportunities for conducting research-work.

Dr Robert Arthur Young was Lecturer on Therapeutics at the Middlesex Hospital Medical School and afterwards Physician to the Hospital. He joined the Society in 1894, and is still a member.

Mr Bird is Mr C. H. Golding-Bird, F.R.C.S., afterwards Surgeon to Guy's Hospital: now Consulting Surgeon. He joined the Society at the October meeting.

October 14th, 1880 (at the Café Monico). Dr Foster also presided at this the fifth Annual Meeting, the other members present being Sanderson, Pavy, Gaskell, Pye-Smith, Dyer, Dew-Smith, Schaefer, McCarthy, Page, Yeo and Pye. Mr Charles Roy was introduced as a visitor by Dr Foster, and Mr Adams Clarke by Mr Yeo.

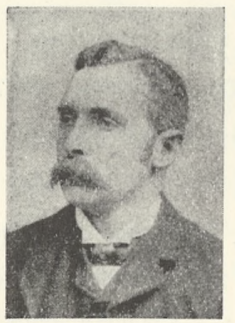

Charles SmartRoy(F.R.S.), was a distinguished physiologist and pathologist. He was educated at Edinburgh, worked with Virchow and Koch in Berlin, with Goltz and Recklinghausen in Strasburg, and with Cohnheim in Leipzig. He was the first George Henry Lewes Student in Physiology (1880). When only 27 years of age he was appointed member of a Commission to report on Leprosy in India. In 1882 he was made Professor Superintendent of the Brown Animal Sanatory Institution in Wandsworth. He was Professor of Pathology in the University of Cambridge from 1884 to 1897, when he died, at the early age of 43 . He was succeeded in the Chair by A. H. Kanthack (who had acted as his Deputy for three years). Kanthack died in the following year, also relatively young. 
The Secretary reported the financial state of the Society to be "most satisfactory." The Committee was appointed as follows: Brunton, Foster, Gamgee, McCarthy, Pye-Smith, Burdon Sanderson and Allen Thomson. The following new members were elected: Jeffrey Bell, C. H. Golding-Bird, J. W. Groves, W. North, J. Parker (Science and Art Department, South Kensington), D'Arcy Power, Charles Roy and A. Waller.

Mr Jeffrey Bell was for many years Professor of Natural History in King's College, London.

Mr W. North was a Cambridge graduate who was at this time working at University College in Burdon Sanderson's laboratory.

Mr D 'Arcy Power (now Sir D'Arcy Power, K.B.E.) is the eminent surgeon, attached to St Bartholomew's Hospital. He is the son of Mr Henry Power, one of the original members. D'Arcy Power has earned the gratitude of physiologists by collecting into one volume copies of all the known or supposed portraits of William Harvey.

Dr Augustus Désiré Waller (F.R.S. 1892), was the son of Augustus Waller, F.R.S., of "Wallerian degeneration" fame, and otherwise distinguished by his researches in connexion with the vasomotor nervous system and the migration of leucocytes.

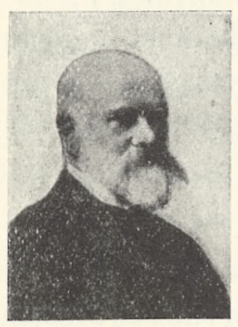

This is the first time the name of A. D. Waller occurs in the minutes. From the first he took a prominent part in the affairs of the Society, and for several years officiated as Treasurer. He will long be remembered for the ingenuity of his methods and the energy with which he pursued any subject in which he became interested. He was successively Lecturer on Physiology at the London School of Medicine for Women, at St Mary's Hospital, and at the London University. His wife (Alice Palmer) materially assisted him in his work. Dr and Mrs Waller both died in 1922, within a few months of one another, to the grief of their friends, amongst whom the members of the Physiological Society and many foreign physiologists were included.

The first International Medical Congress to be held in London had been fixed for the August of 1881, and it was resolved "that the Secretaries be requested to communicate, on the part of the Society, to the physiologists of the Continents of Europe and America, the desire of the Society to welcome them cordially...and to assure each of them a 
hospitable reception in London." The Secretaries were in the meantime directed to ascertain from each member what accommodation he would be likely to be able to offer, before a definite invitation was sent out.

Death of Dr Sharpey. The Secretaries were directed to communicate the following minute to the relatives of the late Dr Sharpey: "That the members of this Society desire to record their sense of the loss they have sustained by the death of a distinguished Honorary Member, the late Dr Sharpey, an event which has deprived Physiology of a true and devoted follower, and physiological workers of a wise counsellor and generous friend."

November 11th, 1880 (at the Café Monico). Dr Pye-Smith was in the chair. The other members present were Sanderson, Foster, Klein, Allchin, Ferrier, Roy, Waller, Langley, Power, Moseley, Groves, Romanes, North and Yeo-with Dr Marcet as Dr Sanderson's guest.

William Marcet, F.R.S., was working in the University College laboratory in a room which was placed at his disposal by Dr Sanderson and, afterwards, by Dr Sanderson's successor. He was engaged at this time with researches on metabolism, investigated both by analysis of gaseous exchanges and calorimetry; he employed a specially constructed ice-calorimeter. He must be regarded. as one of the pioneers in this important department of Biochemistry. He was at one time President of the Meteorological Society. Marcet joined the Society in 1886. He was present as a guest at the inaugural dinner in 1876. He died in 1900.

It was resolved on the motion of Dr Sanderson that the Society meet for scientific work at University College at 4 o'clock on the 9 th December. Also that the ordinary meeting should commence with dinner at 6.30 o'clock instead of 6 .

\section{Inauguration of the Scientific Meetings of the Society}

December 9th, 1880 (at University College). Accordingly on this afternoon the minutes record a special meeting for scientific work held at the Physiological Laboratory under the Presidency of Professor Burdon Sanderson. The attendance is thus recorded in the minutes:

"Were present Messrs Bettany, Brunton, Caton, Bell, Groves, Gamgee, Waller, Klein, Roy, Romanes, Sanderson, Schaefer, Lea, North, McCarthy, Page, Galton, Yeo; as visitors Drs Mahomet, McAlister and Ringer." 
Mahomet is Dr Mahomed, a well-known London physician who wrote extensively on the pulse.

McAlister is now Sir Donald MacAlister, Bart., K.C.B. A distinguished Cambridge graduate, Senior Wrangler and First Smith's Prizeman, he was at this time Lecturer in the Physiological school at Cambridge. He is now Vice-Chancellor and Principal of Glasgow University, and President of the General Medical Council.

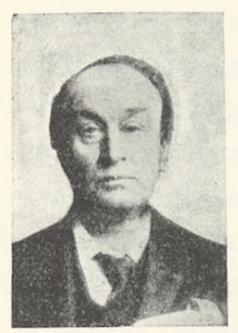

Ringer is Dr Sydney Ringer, F.R.S., best known as the discoverer of the isotonic solution of salts which bears his name. He was attached to University College Hospital as Physician, and was also Professor of Materia Medica, afterwards occupying the chair of Clinical Medicine. Ringer was at this time working in the Physiological Laboratory of University College, engaged upon his classical researches on the frog-heart. He became a member of the Society in 1884. He died in 1910.

The minutes also record that at this meeting Professor Schäfer showed specimens of living muscle and of muscle killed while contracting. Dr Klein showed sections of the submaxillary gland of the guinea-pig, Dr Roy exhibited a microtome for cutting sections of frozen tissues, Dr Waller demonstrated that about fifty stimulations per second produced in his own rectus femoris a tetanus the single contractions of which were not fused whereas the normal voluntary contraction produces a perfectly fused tetanus curve, and Mr Romanes described the locomotion of Echinus.

At the meeting for dinner in the evening the same members were present, with Dr Mahomed, Dr Sydney Ringer and Dr Vincent Harris as guests.

Dr Vincent Harris was attached to St Bartholomew's Medical School, in which he later taught Physiology. He was at one time Editor, with Morrant Baker, of Kirkes' Physiology, a favourite textbook of medical students: the precursor of the well-known work of Professor Halliburton which has become even more popular than the original "Kirkes."

This meeting is notable for two things, namely, first, the invitation to foreign physiologists ${ }^{1}$, and second, because it marks the commencement

1 The invitation is in the following terms:

Dear Sir,

We are directed by the British Physiological Society to invite you to become their guest during the meeting of the International Medical Congress in August next. 
(if we except the small meeting at King's College on January 12th, 1879, which was not immediately repeated) of the special afternoon meetings for the demonstration of physiological work which were afterwards to become the most important feature of the Society. It was at first an understood thing that there should be no sort of publication of the work shown at these special meetings: they were to be private and confidential, and were instituted rather with the view of eliciting remarks and criticism of work in progress than with any idea of preliminary publication of accomplished research. Later it was resolved to print and publish any communication which members might desire. In this way the Proceedings of the Society were commenced, and were regularly published in the Journal of Physiology, the first of such publications appearing in volume IV, dated December 13th, 1883. Until available there, the lists of communications made to the Society will be reproduced here from the Minute Books.

It may be of interest to insert at this place a list of members in 1880 , five years from the foundation of the Society. The dates of election of the newer members are given: the others are original members.
Allchin, W. H., London. 1877.
Balfour, F. M., F.R.S., Cambridge.
Bell, Jeffrey, London. 1880.
Bettany, G. T., Cambridge. 1877.
Brunton, T. Lauder, F.R.S., London.
Caton, R., Liverpool.
Darwin, Francis, Down, Kent.
Dew-Smith, A. G., Cambridge.
Dyer, W. T. Thiselton, F.R.S., Kew.

It is the hope of our Society that the Congress of 1881 will intensify by social intercourse the social feeling which already exists between foreign and English physiologists: and to further this object the Society is prepared to accommodate as many as possible of their foreign friends in private homes, of which the available number is, unfortunately, limited.

We therefore beg of you to be kind enough to let us know, at your earliest convenience, if the Society may expect the pleasure of receiving you as their guest.

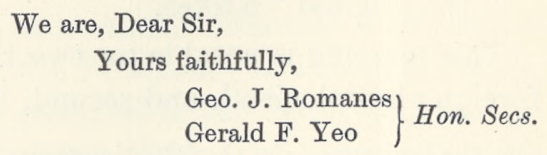

The copy of the letter in the minutes is in Romanes' hand-writing. Forty copies were sent out; unfortunately no record has been kept of the persons to whom they were addressed. 
Ewart, J. C., Aberdeen. 1877.

Ferrier, David, F.R.S., London.

Foster, Michael, F.R.S., Cambridge.

Gamgee, Arthur, F.R.S., Manchester.

Galton, Francis, F.R.S., London.

Gaskell, W. H., Cambridge.

Golding-Bird, C. H., London. 1880.

Groves, J. W., London. 1880.

Huxley, T. H., Sec. R.S., London.

Klein, E., F.R.S., London.

Langley, J. N., Cambridge.

Lankester, E. R., F.R.S., Oxford.

Lea, A. S., Cambridge. 1877.

Marshall, J., F.R.S., London.

Martin, H. N., Baltimore.

McCarthy, J., London.

McDonnell, R., F.R.S., Dublin.

McKendrick, J. G., Glasgow.

Moseley, H. N., F.R.S., Oxford. 1877.

North, W., London. 1880.

Page, F. J. M., London. 1878.

Pavy, F. W., F.R.S., London.

Power, Henry, London.

Power, D'Arcy, London. 1880.

Pye-Smith, P. H., London.

Pye, Walter, London. 1879.

Priestley, J., Manchester. 1878.

Richardson, W. B., F.R.S., London.

Romanes, G. J., F.R.S., London.

Roy, Charles Smart, London. 1880.

Rutherford, W., F.R.S., Edinburgh.

Sanderson, J. B., F.R.S., London.

Schäfer, E. A., F.R.S., London.

Stirling, W., Aberdeen. 1877.

Thomson, Allen, F.R.S., London. 1878.

Vines, S. H., Cambridge. 1877.

Waller, A. D., London. 1880.

Yeo, G. F., London.

Yule, C., Oxford. 
January 13th, 1881 (at the Café Monico). Dr McDonnell in the chair. Were also present Klein, Ferrier, Foster, Sanderson, Yeo, D'Arcy Power, Gamgee, Pye, Roy, Dew-Smith and Romanes, and as guest Dr Cash.

It appears to have been necessary to arrange at a preceding meeting of the Society the place and date of special scientific meetings: we accordingly find a notice to this effect in the minutes of this meeting, King's College, London, being named as the venue.

The minutes of this and of the following meetings, up to and including that of August 5th, are in Romanes' handwriting.

February 10th, 1881 (at King's College). At this meeting Dr Caton was in the chair; other members present were "Sanderson, Foster, Pye-Smith, Klein, Ferrier, Gaskell, Roy, Dew-Smith, North, Bettany, Page, Groves, Bell, Lee (sic), Yeo and Romanes," and as guest, Dr Cash ${ }^{1}$.

Demonstrations were given by Klein of microscopical specimens showing cell-structure, by Gaskell who showed "a remarkable and hitherto unobserved effect on the heart of stimulating the vagus nerve of the Frog. On using as the source of stimulation electrical currents too feeble to produce stoppage, the effect was shown to be a marked increase in the amplitude and power of the heart's action." Also by Roy who gave a demonstration, on a dog, of his oncometer, showing the effect on kidney volume of exciting the sciatic and vagus nerves and of injecting various diuretic substances ${ }^{2}$; and by Sheridan Lea, who "gave, on behalf of Langley, two demonstrations, (1) concerning the digestion of fibrin as effected by certain reagents, and (2) microscopical preparations of frog's liver exhibiting the effect of food and starvation on the liver cells."

The dinner meeting was also held at King's College, with Dr Caton in the chair, most of the above-named members being present, and, as guests, Dr Stirling ${ }^{3}$, introduced by Lea, Professor Buchanan Baxter, by Yeo, Mr Watson Chain (sic), by Groves, and Mr Waters, by Foster.

A vote of thanks to $\mathrm{Dr} Y$ Yeo for the admirable manner in which arrangements had been carried out for this and the last scientific meeting was passed.

1 Dr Cash is entered in the minutes as a member present, but he was not yet elected.

2 The minutes contain a long account of this demonstration, and include a description of an apparatus used by Roy for artificial respiration devised by $\mathrm{Mr}$ Horace Darwin and constructed by the Cambridge Scientific Instrument Co.

3 If this is Dr William Stirling it must be a mistake to include him amongst the guests, since he was elected a member in 1877 . 
On the invitation of Dr Foster it was decided to hold a scientific meeting at Cambridge in June (the meeting was actually held in July).

March 10th, 1881 (at the Café Monico). This meeting was only attended by four members. Dr Klein was in the chair: the others were Sanderson, Dew-Smith and Romanes. Evidently a dinner without a scientific meeting to precede it was not now very attractive.

July 9th, 1881 (at Cambridge). The following communications and demonstrations were given at the scientific meeting:

Dr Rutherford: The structure of striped muscle.

Dr Gamgee: The ferments of Papaia.

Dr Sanderson: A new and more compact form of Compensator.

Mr Page: An improvement in his gas-regulator (thermostat).

Mr Langley: The histological changes of the secreting cells of the stomach during action and repose.

Dr Gaskell: A demonstration of the trophic action of the vagus nerve on the heart.

Dr Roy: The rhythmic changes in volume of the spleen as recorded by his oncometer.

Dr Pavy: On hydrocarbons [fats].

Detailed abstracts of most of these communications are recorded in the Minute Book.

The dinner was held in the Hall of Christ's College. "Were present: Dr Foster (in the chair), Sanderson, Gamgee, Rutherford, Pavy, Power, Pye-Smith, Roy, Gaskell, Klein, Dew-Smith, Langley, McCarthy, North, Page, Waller, Vines, and Romanes. And as guests: Dr Latham, introduced by Dr Pavy, Dr Cash, introduced by Dr Roy, Professor Humphry, introduced by Dr Foster, Mr Ernest Hart, introduced by Mr Romanes, Mr Waters, introduced by Mr Dew-Smith, Mr H. Darwin, introduced by Dr Gaskell, Mr Cartmell, introduced by Mr Langley, Mr Salvin, introduced by Sanderson, Mr Thompson, introduced by Pye-Smith, Professor Newton, introduced by Vines, Mr Hill, introduced by $\mathrm{Dr}$ Gamgee."

Dr Latham was Downing Professor of Medicine at Cambridge from 1874 to 1894 . In 1888 he was Harveian Orator, choosing as his subject "Blood changes in Disease."

Dr John Theodore Cash, F.R.S.; until recently Professor of Materia Medica in the University of Aberdeen. He was elected a member in October, 1881. 
Mr Waters is W. Horscraft Waters, who was Demonstrator of Physiology in the Owens College, Manchester. He joined the Society in 1882 and died in 1887.

Mr Salvin is probably Mr Osbert Salvin, F.R.S., who was Strickland Curator, University of Cambridge.

Professor A. Newton, F.R.S., the eminent ornithologist, was Professor of Zoology in Cambridge. He died in 1907, aged 78.

Mr Horace Darwin (F.R.S. 1893), now Sir Horace Darwin, K.B.E., the youngest son of Charles Darwin, was for a long time associated with Dew-Smith in carrying on the Cambridge Scientific Instrument Company, of which he became Managing Director (p. 27).

Further arrangements were made as to inviting foreign physiologists to the International Medical Congress in August, 1881. It was decided to entertain all who had accepted, at dinner on August 8th in London (the date was afterwards changed to August 5th).

A discussion was raised as to the policy to be adopted with regard to the accusations made against physiologists by anti-vivisection agitators, Mr Ernest Hart being invited to give his opinion on the matter. Eventually, on the motion of Dr Sanderson, a committee was appointed to consider the question and report to the next meeting of the Society.

\section{Dinner to Foreign Physiologists}

August 5th, 1881 (at St James's Hall, London). The next record in the minutes reads as follows: "At an extraordinary meeting of the Society held at St James's Hall [Restaurant] on August 5th were present, Dr Foster in the chair ${ }^{1}$, Pye-Smith, Ewart, McCarthy, Pavy, Power, Klein, Rutherford, Gamgee, Sanderson, Gaskell, Roy, Yeo, Schäfer, Langley, Waller, McDonnell, Lea, F. Darwin, North, Page, Groves, Huxley, Lankester, Dew-Smith and Romanes. There were also present as guests, Drs Watney, Harvey, Purser, Waters, Charles, Haycraft, Roxburgh, Stuart and Pike, as well as the following foreign visitors: Kronecker, Goltz, Ewald, Dastre, Morat, Lovèn, Grünhagen, Chauveau, Franck, Waldstein, His, Mayer, Lépine, Brown-Séquard, Bowditch, Jacobi, Wood, Preyer ${ }^{2}$."

1 Foster was President of the Section of Physiology at the International Medical Congress. He gave a scholarly address on "The History of Physiology in England," which is published in the British Medical Journal for 1881, vol. 2, p. 587.

2 Although all these names are entered in the minutes as "guests invited by the Committee," it is probable that only the foreign guests were so invited, the others having been guests of individual members of the Society. 
Dr Herbert Watney was attached to St George's Hospital as Assistant Physician and Lecturer on Physiology. He worked in Professor Sanderson's laboratory at University College, and with Dr Klein at the Brown Institution, his chief work being on the structure of the Thymus.

Stuart is probably Anderson Stuart, at that time Assistant to the Professor of Physiology in Edinburgh, and afterwards Professor in Sydney University. He was knighted in 1914. He died in 1920.

Charles is either Arthur Charles, Professor of Physiology in Queen's College, Cork, or J. J. Charles, Lecturer in Physiology at St Thomas's Hospital medical school, probably the latter.

Kronecker is Professor Hugo Kronecker of Bern. Kronecker, after working with Helmholtz in Heidelberg, became Privat-Docent and Assistant in Ludwig's laboratory in Leipzig; and subsequently Professor Extraordinarius in Du Bois-Reymond's Institute in Berlin. He was appointed to the chair of Physiology in Bern in 1884. In 1895 the third International Congress of Physiology was held in his Institute (the Hallerianum). He was a frequent visitor to this country and a close friend of British physiologists who always found a hospitable welcome wherever he was installed.

Professor F. Goltz was the first Professor of Physiology in Strasburg after the war of 1870. A skilful investigator, he published a remarkable series of papers on the functions of the nervous system, several of which have become classical.

Professor C. A. Ewald was a physician in Berlin, author of a well-known book on digestion.

Professor A. D astre is the well-known French physiologist, pupil of, and eventually successor to, Claude Bernard and BrownSéquard. He died in 1917.

Professor J. P. Morat was Professor of Physiology in Lyons-he was also one of Bernard's pupils.

Professor Chr. Lovèn was Professor of Physiology in Upsala. He was present at the inaugural dinner in 1876 .

Professor W. His, the well-known embryologist, was Professor of Anatomy in Leipzig.

Mayer was probably Sigmund Mayer, who became Professor of Physiology in the German University in Prag.

Dr Lépine, who had worked with Ludwig in Leipzig, was Professor of Medicine in Lyons.

Professor Brown-Séquard is the well-known physiologist, 
successor to Claude Bernard at the Collège de France in 1878. He died in 1894.

Professor Henry Bowditch was for many years Professor of Physiology at Harvard. He worked with Ludwig and Kronecker at Leipzig - chiefly studying the conditions of action of the frog-heart. Although he did not himself produce a great deal of original work, yet, like Michael Foster at Cambridge, he had the valuable faculty of surrounding himself with active investigators whom he assisted by wise counsel and criticism. He died in 1911.

Dr W. A. Grünhagen was Emeritus Professor of Physiology in Königsberg.

Professor A. Chauvea u was for many years Professor of Physiology in the great Veterinary College at Lyons. He subsequently occupied an important official position in Paris. He died in 1917.

Franck is probably DrCh. A. François-Franck, who was present at the inaugural dinner in 1876.

DrWilliam Preyer was Professor of Physiology in the University of Jena from 1888 to 1893 . He was the author of a well-known monograph on Hæmoglobin (Die Blut-Krystalle). He was at this time interested in hypnotism, which he successfully practised on several of his colleagues at the Congress; but his efforts to hypnotise Yeo only served to exhaust the hypnotiser.

After dinner the Chairman first proposed the health of Her Majesty the Queen, and then the foreign guests, coupling the toast with the names of Drs Chauveau and Goltz, who responded. The Chairman next made a complimentary allusion to the presence of Dr Brown-Séquard, who also responded.

The report of the committee appointed at the last meeting to consider the subject of vivisection was adopted. It recommended the publication of a series of articles in a leading Review explaining the methods and aims of physiological research and the extent to which modern medicine is likely to be benefited by it, and suggested the names of leaders in the medical and scientific professions who might be asked to write such articles. Amongst these names were those of Sir James Paget, Sir William Gull, Sir Robert Christison, Mr Charles Darwin, Mr Huxley, Mr Lister, Dr Andrew Clarke, and Dr McDonnell. But nothing seems to have come of the suggestion.

A vote of thanks to the Chairman was proposed by Mr Huxley, which, having been unanimously carried, the Chairman briefly acknowledged. 
October 15th, 1881 (at the Café Monico). This was the sixth Annual Meeting. "Were present, Dr J. Burdon-Sanderson in the chair; also Messrs Balfour, Page, Moseley, Langley, Vines, Gaskell, Roy, Klein, McCarthy, North, Ferrier, Waller, Groves, Lea, Power (d'Arcy), PyeSmith, Foster, Marshall and Yeo, and as visitors, Dr Scott, introduced by Mr Vines, Dr de Watteville, by Mr Pye, and Dr Gowers, by Yeo."

Dr Scott is D. H. Scott, F.R.S., the eminent botanist.

Dr de Watteville was a well-known neurologist and electrotherapeutist. At this time he was working at Histology in Sanderson's laboratory at University College. He died in 1926.

Dr Gowers, afterwards Sir William Gowers, F.R.S., is the celebrated neurologist. He was Physician to University College Hospital and to the National Hospital for the Paralysed and Epileptic, Queen Square. He died in 1915.

The Treasurer reported a credit balance of $£ 18.8 s .6 d$.

The Committee for the ensuing year was elected, and also the following new members of the Society: Dr Reuben J. Harvey (Dublin), and Dr J. Theodore Cash (London).

It was stated that the dinner given by the Society on August 5th had cost $£ 50$; the Committee recommended that each member should contribute one guinea to meet this expense. This suggestion was adopted and the Secretaries were empowered to collect that sum from the members.

It was proposed by Dr M. Foster and carried that a committee consisting of Pye-Smith, Lauder Brunton and one of the Secretaries, should be asked to prepare a report on the working of the Vivisection Act, with an account of the obstacles which had been experienced in obtaining licences and certificates, and recommendations regarding any action which might be taken by the Society.

November 10th, 1881 (at the Café Monico). Dr P. H. Pye-Smith in the chair. Fourteen other members (Pavy, Foster, McCarthy, Cash, Roy, Klein, Sanderson, Dew-Smith, Bell, Schaefer, Lea, Page, Waller and Yeo) and two guests (Dr Conolly Norman and Mr Humphry) were present.

Mr Humphry is probably Professor Humphry of Cambridge.

It was decided, on the motion of Professor Foster, that of the two Secretaries $\mathrm{Mr}$ Romanes be requested to act as Treasurer, the secretarial duties being left to Professor Yeo. 
The minutes conclude "After some desultory conversation on current topics the meeting terminated."

December 8th, 1881 (at University College). At a special afternoon meeting at University College demonstrations were given as follows:

F. J. M. Page (by means of the capillary electrometer): Strychnia spasms in the frog-gastrocnemius, with waves of eight per second, as described by Lovèn.

A. D. Waller: The effect of different ways of stimulating the muscles of his own leg.

Charles Roy: Two cardiographs.

W. North: An apparatus for analysing expired air; devised by Dr Marcet.

E. A. Schäfer: (a) A ready means of testing the reaction of blood; (b) The coagulation temperatures of serum-albumin; (c) A new inclined plane microtome; $(d)$ A new accessory ligament of the malleus.

T. L. Brunton: A frog-heart cannula and cardiograph.

E. Klein: Microscopical preparations of Jacobson's organ and of nuclear division.

At the dinner meeting on the same date "were present Dr Sanderson in the chair, Ferrier, Brunton, Foster, Harvey, Bettany, Priestley, Waller, Klein, Schaefer, Page, Romanes, Bell, Groves, Roy, Dew-Smith, Yeo and McCarthy, and as guests Dr de Watteville, introduced by Waller, Dr Fitzgerald, introduced by Yeo, Professor Thane, introduced by Schaefer, Mr Dowdeswell, introduced by Klein, Mr Forbes, introduced by Burdon-Sanderson."

Professor Thane, now Sir George Thane, was for many years in the Chair of Anatomy in University College.

Mr George Dowdeswell was working with Klein and Sanderson on the subject of inflammation.

\section{Working of the Vivisection Act}

At this meeting the report of the committee on the working of the Vivisection Act, appointed on October 15th, was considered and adopted, printed copies of the Report ${ }^{1}$ having been circulated to members. It would appear from this that there had been many instances of interference with work on the part of the Home Office.

1 The Report is a long one. A copy is preserved in the Minute Book. 
Three were selected as cases which might be brought to the notice of the Home Secretary, these being Professor Fraser's on the action of Borneo poison, Dr Brunton's on the treatment of snake bites, and Professor Lister's on means of stopping arterial hæmorrhage. But as the London Executive of the International Medical Congress was already in communication with the Home Office on the whole subject it was recommended that the Society leave the matter in its hands, affording all necessary information. A significant sentence occurs in the Report, namely, "that the Act is capable of being a protection instead of a hindrance if reasonably administered." The committee recommended "that workers in Physiology should only apply for such certificates as are necessary for their special purpose, that they should always be prepared to show their scrupulous attention to the provisions of the Act... and that they should never be deterred from applying for the necessary certificate by the chance or the certainty of its being disallowed."

January 12th, 1882 (at the Café Monico). Dr Lauder Brunton was in the chair; other members present were Ferrier, Roy, Gaskell, Klein, Pye, Groves, McCarthy and Yeo, and one guest (Dr Norman, introduced by Ferrier). It was arranged that the next meeting should be held at King's College and that it should be preceded by a scientific meeting.

The members having been informed of the death of Dr Reuben J. Harvey of Dublin, a recently elected member, a resolution was adopted recording the regret of the Society at the loss sustained by Physiology and by his colleagues and friends.

February 9th, 1882 (at King's College). The special meeting above referred to was held on this date. The following communications were made:

J. N. Langley: On the condition of the right side of the brain of the dog exhibited by Professor Goltz at the International Medical Congress, with macroscopic and microscopic drawings.

E. Klein: On the left side of the same brain, also showing drawings.

E. A. Schäfer: On the brain of the monkey exhibited by Dr Ferrier at the Congress, with sections and drawings.

T. Lauder Brunton: An apparatus for studying the effects of heat and cold on the circulation in the frog's lung.

F. Gotch: Tetanus curves, indicating effects of different strengths of stimulus.

$\mathrm{PH}$. 
F. J. M. Page (for Dr Ringer): Frog-heart curves.

W. North: Samples of food from Teneriffe.

J. N. Langley: Stages of secretive activity of the liver cells of the frog.

J. W. Groves: A freezing microtome.

G. F. Yeo: An apparatus for resuscitation of drowning persons, invented by Mr Graham Bell, of telephone celebrity.

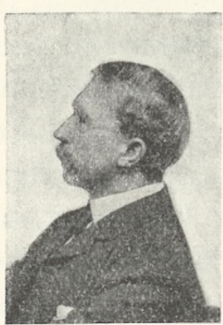

This is the first mention in the minutes of Francis Gotch, who was born at Bristol in 1853, son of the Rev. Dr Gotch, a Baptist Minister and an eminent Hebrew Scholar, a member of the Board for the Revision of the Old Testament. Gotch was educated at Amersham Hall School and at University College. He had been Sharpey Scholar in Physiology and was at this time Assistant in the Physiological Laboratory of University College. When Burdon Sanderson went to Oxford in 1883 Gotch accompanied him and not only aided in organising the teaching there, but assisted in the electrophysiological researches which Sanderson was engaged in. In 1891 he was appointed to the Hull chair of Physiology in the newly constituted University of Liverpool vice Dr Caton, who for many years had been teaching that subject in the University College of Liverpool, but now gave this up in order to devote himself entirely to clinical medicine. When Burdon Sanderson in 1894 exchanged the Waynflete Professorship of Physiology in Oxford for the Regius Chair of Physic, Gotch was appointed to succeed him and held the post until his death in 1913. He was elected F.R.S. in 1892. He married a sister of Victor Horsley.

At the dinner meeting on the same day were present: Mr Henry Power (in the chair), Foster, Gamgee, Ferrier, Klein, Sanderson, Waller, Gaskell, Roy, Dew-Smith, Groves, Romanes, Langley, Moseley, Lankester, D'Arcy Power, McCarthy, North, Page and Yeo. No special business is recorded.

March 9th, 1882 (at the Café Monico). Dr Klein was in the chair: other members present were Foster, Sanderson, Roy, Gaskell, Cash, Dew-Smith, Bell and Yeo, and one visitor (Mr J. A. Scott, introduced by Yeo). It was resolved that the next meeting be held in July at Cambridge and be preceded by a special scientific afternoon meeting. 
July 15th, 1882 (at Cambridge). The following communications were made at the afternoon meeting:

E. Klein: The infective powers of Bacterium anthracis.

W. H. Gaskell: The nerve mechanisms of the heart of the tortoise.

Th. Cash: An instrument for the graphic registration of the movements of the frog's heart in situ.

Ch. Roy: A new method of recording the motions of the mammalian heart-chambers.

H. Newell Martin: Method of sustaining the mammalian heart alive by artificial circulation.

The dinner meeting was held at "The Hotel" in Cambridge with Professor Michael Foster in the chair. There were seventeen other members present-Sanderson, Brunton, Gaskell, Cash, Klein, PyeSmith, Roy, Vines, Martin, Dew-Smith, Golding-Bird, Groves, Francis Darwin, Page, Langley, McCarthy and Yeo-and six guests-Messrs Miles, Wooldridge, Evans, Scott, Gotch and Mekins. The meeting "expressed its cordial good wishes to Dr H. N. Martin [Professor in Baltimore since 1877 , p. 36] who, for the first time, was present at one of the scientific meetings."

A resolution was passed thanking the Council of the British Medical Association for their support on the occasion of the prosecution of one of the members of the Society under the Cruelty to Animals Act.

The prosecution was that of Dr Ferrier for his work in conjunction with Professor Yeo on the brain of monkeys: Dr Ferrier not having taken out a licence to operate on living animals. It was, however, proved that the operations were entirely carried out by Professor Yeo, who was furnished with a licence, and the case against Ferrier broke down.

October 14th, 1882 (at the Café Monico). This was the seventh Annual General Meeting. Dr Pavy was in the chair. The following members were present: Sanderson, Klein, Roy, Gaskell, Waller, Brunton, Cash, Lankester, Foster, Lea, Dyer, Page, Bell, McCarthy, D’Arcy Power, Schafer, H. Power and Yeo. There were also three guests, namely, Dr Vignal, introduced by Brunton, Dr Delépine, introduced by Sanderson, and Mr W. T. Brooks, introduced by Yeo.

Dr Vignal was a distinguished French histologist.

Dr Delépine became Professor of Pathology in Manchester: he joined the Society in 1886, and died in 1921.

Mr Walter Tyrrell Brooks joined in 1885 . 
The Secretary reported (1) that the three scientific meetings held in the previous session had been most useful in promoting the objects of the Society; (2) (on behalf of the Treasurer) that the finances of the Society were in a very satisfactory condition; (3) that the Committee had decided that the rule according to which a member who had not been present at any meeting of the session should cease to belong to the Society "shall not be put in operation in any case"; (4) that Mr Francis Galton having expressed a wish to resign, the Committee had directed the Secretary to thank him for his previous support and to express regret at the receipt of his resignation; (5) that since the last winter session the Society had lost by death its brilliant Honorary Member, Charles Darwin ${ }^{1}$, and its distinguished ordinary member, Francis Balfour ${ }^{2}$. [The adjectives in this resolution would perhaps have been more appropriately placed in the reverse order.]

With respect to (5) the draft of a resolution occurs in the Minute Book, written in pencil and nearly illegible, which probably expresses an attempt then and there to voice the feelings of the Society-an attempt which seems to have eventually been given up. The draft reads as follows: "The effect produced in the scientific world by the death of Charles Darwin is so universal and profound that any formal motion in reference to it by this little Society would appear to be superfluous, if not impertinent.

The actual loss to science by the untimely death of Francis Balfour may prove greater than that following the death of the great Darwin (which took place when he was at a mature age and had accomplished so great triumphs). No set of persons can appreciate this more than the members of this Society. But the sorrow felt by many of them to whom he was so dear a friend is too keen and their love for him too warm to bear expression in the words of a cold minute ${ }^{3} . "$

It was agreed to alter Rule IV of the Society so as to enable the number of Honorary Members resident in Great Britain to be increased to six.

There is nothing said in the original rules in the Minute Book about residence in Great Britain. Rule IV simply states "The

1 Died at Downe, Beckenham, on April 19th, 1882.

2 See p. 37.

${ }^{3}$ Nevertheless, at the next meeting of the Society, on November 9 th, a definite resolution regarding their loss was put on the minutes, although it was left to the Secretary to make the feeling of the Society known to the respective families. 
number of Honorary Members shall not exceed five." As a fact only two Honorary Members had been elected, Charles Darwin and William Sharpey, and both were now dead.

As already pointed out, there was no special provision for alteration of rules, and it appears to have been the practice to change a rule at any meeting and without previous notice. This seems to have been done on the present occasion.

The following were elected honorary members: Sir William Bowman, Dr William Benjamin Carpenter, Professor Thomas Henry Huxley, Professor John Marshall, Sir James Paget, Bart., Dr Allen Thomson.

Some of the letters acknowledging the honour have been preserved. That of Professor Huxley is characteristic. After thanking the Society he remarks: "I have been such a bad attendant that I deserve to be made a 'Dis-honorary' member-but my failure has not arisen from want of interest in the objects of the Society.

The following were elected ordinary members: Francis Gotch, Donald McAlister, George Dancer Thane, William Horscraft' Waters, Leonard Charles Wooldridge. The officers and Committee were also elected.

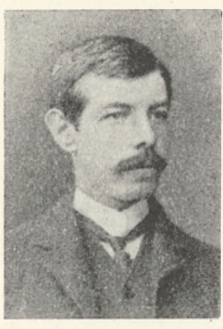

This is not the first mention of Wooldridge in the minutes of the Society, for he was a guest at the Cambridge meeting in July. A brilliant young investigator, he early made a mark in Physiology, his work being chiefly on the chemical side. He is best known for his investigations into the phenomenon of blood-coagulation, which have become classical. He succeeded Pye-Smith as lecturer on Physiology at Guy's Hospital. He died prematurely, to the grief of his colleagues and friends, in 1889 (p. 90). His widow, who was the daughter of Dr Sieveking, a distinguished London physician, was afterwards married to Ernest Starling.

November 9th, 1882 (at the Café Monico). This was solely a dinner meeting. Dr Klein was in the chair. Sir James Paget, one of the newly elected Honorary Members, attended, and the other members present were Burdon Sanderson, Michael Foster, Roy, McAlister, Thane, McCarthy, Yeo and Priestley. There were three guests, namely, Dr "Sprengel, introduced by Klein, Dr Horwicks, introduced by Priestley, and Professor Horwart, introduced by Foster ${ }^{1}$.

1 "Horwicks" and "Horwart" are probably misspellings, but this is as they appear in the minutes. 
Sir J a mes $\mathrm{P}$ a g et, F.R.S., is the famous surgeon who was attached to St Bartholomew's Hospital. He was created a baronet in 1871, and was President of the Royal College of Surgeons in 1875 and of the International Medical Congress in London in 1881. He died in $1899^{1}$.

Dr Sprengel (F.R.S. 1878) was a chemist and physicist, well known as inventor of a continuously acting mercury vacuum pump, and also for his discoveries of the picric acid explosives. He died in 1906.

December 9th, 1882 (at University College). At the afternoon meeting communications were made as follows:

A. D. Waller: Photographic records of galvanometer deflections.

F. J. M. Page and Burdon Sanderson: Photographic method of recording electrical changes.

E. A. Schaefer: Photographic record of changes in the volume of the frog's heart.

G. J. Romanes: Physiology of the Echinodermata.

Sydney Ringer: The effects of lime and potash on the frogheart.

W. North: A new dynamometer.

F. Gotch: A modification of Fleischl's rheonome.

Ch. Roy: The mammalian heart.

At the dinner in the evening Dr Sanderson was in the chair. The other members present were Thane, Schaefer, Ferrier, Roy, Bell, Klein, Gaskell, North, D’Arcy Power, Page, Romanes, Golding-Bird, McCarthy, Gotch, Groves. There were also six guests, viz. Drs Mekins, Sainsbury, Walton, Messrs Fenwick and Laws, and Dr Acland.

"Dr Acland." It does not appear whether this is the distinguished Regius Professor of Physic in the University of Oxford who was made K.C.B. in 1884 and created a baronet in 1890 or his son Dr Theodore Acland, who afterwards joined the Society. He was introduced by Sanderson, and therefore it was probably the Professor, who had just succeeded in getting Sanderson to accept the Oxford Chair of Physiology. Sir Henry Acland was President of the General Medical Council from 1874 to 1887 . He died in 190 .

1 His Life was written by his son, Mr Stephen Paget, F.R.C.S., who was also Surgeon to St Bartholomew's Hospital but retired early from practice. Stephen Paget acted for many years as Honorary Secretary of the Research Defence Society and was a notable champion of experimental medicine. He died in 1926. 
January 11th, 1883 (at the Café Monico). This was a dinner meeting. Dr Carpenter, one of the newly elected honorary members, was in the chair; there were seven other members present, viz. Klein, Waller, PyeSmith, McAlister, Schaefer, Langley and Yeo. The only business transacted was a decision to hold the next meeting at King's College, and that it should be preceded by an afternoon meeting.

February 10th, 1883 (at King's College). At the afternoon meeting the following demonstrations and communications were made:

Ferrier: The brain of a monkey which was exhibited as deaf at the International Medical Congress in August 1881.

Brunton: A new 3-way stopcock for giving anæsthetics by the trachea.

Groves: A frog-trough for examining living tissues under the microscope.

Klein: Pink yeast torulae.

Watson Cheyne: Work on the tubercle bacillus.

Schaefer: Photographic tracings obtained with a new heart manometer.

Cash: Muscle curves from kittens.

Evans: Sections of spleen which illustrated the blood current in that organ.

Gaskell: The method of educating the tortoise ventricle to perform automatic rhythmic contractions.

Yeo: A tube of diluted blood which had been put up aseptically and still showed the two bands of $\mathrm{HbO}_{2}$ after a period of five months.

At the corresponding dinner meeting Dr Sanderson was in the chair; the following members were also present: Pye-Smith, Klein, McCarthy, Cash, Gaskell, Roy, Foster, Lea, Gotch, Groves, Schaefer, Thane, Bell, and Yeo: besides six guests, Messrs Evans, Collins, Brooks, Herroun, Cheyne and Sibley. No business is recorded.

March 8th, 1883 (at the Café Monico). This was a dinner meeting. Dr Pye-Smith was in the chair and seven other members were present, viz. Klein, Allchin, Cash, Dew-Smith, Groves, Roy, Lea. It was resolved to meet on July 21st at Cambridge on the invitation of Dr Foster.

July 21st, 1883 (at Cambridge). A scientific meeting was held in the afternoon in the Physiological Laboratory. Were present: Professor 
Foster (in the chair), Pye-Smith, McCarthy, Waller, Klein, McAlister, Lea, Yeo, Waters, Vines, Langley, Dew-Smith, and, as guests, Messrs Brooks, Sherrington, Evans, Humphry (probably Professor Humphry), Eve, Head, Herroun and Caldwell.

This is the first mention of Sherrington's name in the minutes, and although he appears again more than once as a guest, he did not actually join the Society until November 1885. He succeeded Yeo as Secretary in 1889.

Dr Henry Head (F.R.S. 1899) is the distinguished neurologist. He joined the Society in 1887 and was elected an Honorary Member in 1925. He was knighted in January 1927. He became physician to the London Hospital and to the National Hospital for the Paralysed and Epileptic, Queen Square.

Mr Caldwell was an embryologist who was engaged in investigating the development of Monotremes.

Mr E. F. Herroun was Demonstrator of Physiology at King's College, London.

The following communications were made:

W. H. Caldwell: The mode of using a new continuous mechanical automatic microtome. [This was the well-known "Cambridge Rocking Microtome," by the use of which a series of sections of organs or embryos embedded in paraffin could be cut and mounted.]

E. Klein: Microscopic specimens of stained bacilli in blood.

A. Sheridan Lea: The amylolytic ferment of the liver.

E. F. Herroun: A process of making urea from benzene, ammonia and air.

The dinner meeting was held the same evening at the Prince of Wales Hotel, Cambridge, Professor Foster in the chair, with the same members and visitors as were present at the scientific meeting. No business is recorded.

October 20th, 1883 (at the Café Monico). This was the eighth Annual General Meeting. Were present: Michael Foster (in the chair), Bell, Bettany, Cash, Dew-Smith, Gaskell, Gotch, McAlister, McCarthy, Page, Pavy, Pye, Schäfer, Vines, Waller, Klein, Roy, Yeo ${ }^{1}$. Also as guests, Dr Ringer, introduced by Mr Page, and Dr Mason, introduced by

1 This seems to have been the only occasion on which our first Secretary attempted to arrange the names alphabetically. He nearly succeeded. 
Dr Roy. The Committee and Officers and two new members were elected, namely, Professor Thomas R. Fraser and Mr Clinton T. Dent.

Professor Fraser, afterwards Sir Thomas Fraser, F.R.S., was Professor of Materia Medica in the University of Edinburgh from 1877 to 1918.

Mr Thomas Clinton Dent was Surgeon to St George's Hospital and Hon. Secretary of the Association for Advancement of Medicine by Research, to which the Home Secretary was in the habit of referring applications for licences and certificates under the Act 39 and 40 Vic. cap. 77. Dent was a distinguished traveller and alpinist; he was President of the Alpine Club from 1886 to 1889. He died in 1912, aged 61 .

An opinion was generally expressed that there was sufficient material for a greater number of scientific meetings and the Committee was directed to take the matter into consideration.

November 8th, 1883 (at the Café Monico). Dr Pye-Smith was in the chair. The following members were also present: Foster, Roy, Klein, Groves, Bell, D'Arcy Power, Thane, Dent and Yeo-and one guest, Dr Curnow, introduced by Yeo.

Dr John Curnow was Professor of Anatomy in King's College, and later became Professor of Clinical Medicine. He died in 1902.

The report of the Committee on the subject of scientific meetings was read and adopted. The chief recommendations in the report were the addition of a fourth scientific meeting (at Oxford) and an occasional extra one in London: this would reduce the merely dinner meetings to three or even to two in the year.

The report also discusses the possibility of publishing the proceedings of the scientific meetings in the Journal of Physiology and suggests a close relationship between the Journal and the Society with a view to their mutual benefit and support ${ }^{1}$. Professor Michael Foster, the editor and proprietor of the Journal of Physiology, who was present, said there would be no difficulty in publishing the proceedings in the Journal, "at the expense of the Society." $\mathrm{He}$ suggested that they might be printed in sheets for use at the meeting at which the communications were made, and the sheets would then

1 But forty-three years were to elapse before this union could be brought about. 
be ready for insertion in the Journal. But since it was pointed out that the present subscription of $10 \mathrm{~s}$. $6 \mathrm{~d}$. could not possibly cover the expense involved, the matter was left over, and notice was given by $\mathrm{Mr}$ Groves of a motion to increase the subscription.

December 13th, 1883 (at University College). At the afternoon meeting communications were made by Sydney Ringer, Victor Horsley, J. McWilliam, W. D. Halliburton, E. A. Schäfer ${ }^{1}$.

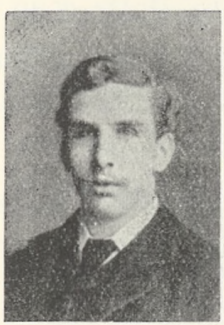

This is the first appearance of Victor Horsley's name in the Minute Book. A distinguished student of University College and graduate of the University of London, he became Assistant Surgeon and afterwards Surgeon to University College Hospital. He succeeded Dr Charlton Bastian as Professor of Pathology at University College. He made numerous observations and experiments on the thyroid, and, in association with Professor Schäfer, Dr Charles Beevor and others, upon the localisation of functions in the brain, working especially on monkeys and the higher apes. He became one of the chief neurological surgeons of the day and was the first surgeon to be appointed at the National Hospital for the Paralysed and Epileptic in Queen Square, Bloomsbury. Joining the Society in 1884, he took a prominent part in its proceedings. He was elected F.R.S. in 1886 and in 1894 received a Royal Medal for his work on the nervous system and on the thyroid. He was knighted in 1902. On the outbreak of the Great War he placed his services at the disposal of the military authorities and was given a commission in the R.A.M.C. He served in France, Egypt and India, and finally in Mesopotamia, where he died of sunstroke at Amarah on July 16th, 1916, in his sixtieth year, to the regret of all who knew him. His life, written by Mr Stephen Paget, is a fascinating story, told with the charm which Mr Paget put into all his writings and full of interesting personal details: the reader must go to this to understand what manner of man Victor Horsley

1 Abstracts of these are given in the minutes. As they also appear in vol. Iv of the Journal of Physiology, they have been omitted from this account. Abstracts of the communications made at all future meetings were, from now onwards, published in that Journal and were therefore generally omitted from the Minute Books. Somewhat later the titles of communications were again inserted in the minutes but there is considerable irregularity in this respect. 
was - and how he came to take an active part both in medical and in general politics as well as in science.

J. McWilliam is Dr John Alexander McWilliam (F.R.S. 1916), Professor of Physiology in the University of Aberdeen since 1886. He had recently been appointed Assistant to the Professor of Physiology in University College, London, and was working at the nervous mechanisms of the eel's heart.

Dr W.D. Halliburton (F.R.S.1891), whose name also now occurs for the first time in the minutes of the Society, was Sharpey Scholar in Physiology and succeeded McWilliam as Assistant in 1886. In 1890, on the retirement of Professor Yeo from the chair of Physiology in King's College, Halliburton was appointed to succeed him and held the post until 1925, when he retired and was succeeded by R. J. S. McDowall.

At the dinner meeting held at University College the same evening Professor Schäfer was in the chair: other members present being Sanderson, Foster, Jeffrey Bell, Thane, Klein, Pye-Smith, McCarthy, Cash, Romanes, Bettany, Golding-Bird, Page, and Yeo.

It was decided at this meeting that the offer on the part of the Journal of Physiology to publish abstracts of the proceedings of scientific meetings be accepted, and that the subscription be raised to $£ 1$; also that all meetings be held on Saturdays instead of Thursdays. The Committee was instructed to arrange for revision of the rules in accordance with these decisions.

January 19th, 1884 (at King's College). Mr Henry Power was in the chair at the dinner: other members present were Foster, Thane, Schäfer, Klein, Pye-Smith, Cash, Gaskell, Roy, Dent, Langley, Lea and Grovesand four guests, viz. Drs Mortimer Glanville, McWilliam, Sherrington and Sandford Moore.

Professor Yeo mentioned that his work had been obstructed by the Home Office, and Mr Clinton Dent informed the members that the Home Secretary was to receive a deputation from the Society for the Advancement of Medicine by Research on the question of withholding certificates.

March 15th, 1884 (at Cambridge). The following members were at the dinner, viz. Bell, Caton, Golding-Bird, Gotch, Langley, Lankester, Lea, McAlister, Page, Pye, Schäfer, Waller, Wooldridge, Cash, Gaskell, PyeSmith, Roy, Sanderson and Yeo, with Professor Michael Foster in the chair. Two guests, viz. A. McAlister (Professor of Anatomy) and 
E. F. Herroun, are mentioned in the minutes as being present, with the remark added by the Secretary "and many others whose names were not returned in accord with rule $21 . "$

\section{Alteration in the Constitution of the Society}

The necessary alterations in the rules were discussed and passed ${ }^{1}$. The chief changes were the increase of the subscription to $£ 1$ : one blackball in five (instead of one in three) to exclude from membership: and the Annual Meeting to be held in November instead of October. But the most important change was the abolition of a limit to the number of members. In the original rules the limit was forty: in 1878 this number was raised to fifty: now it disappears, as does the qualification that all the members shall be working physiologists - a qualification which was from the first more honoured in the breach than in the observance.

The removal of the numerical limitation altered the whole character of the Society. While the membership was restricted members were personally, in many cases intimately, known to one another. At the Cambridge and Oxford meetings, those London and provincial members who were able to stay were hospitably entertained for the week-end by their University colleagues. On the Sunday there were generally boating or garden parties; for the latter, Cambridge especially offered unusual facilities, owing to the fine gardens attached to the houses of several of the members.

The London physiologists (with their ladies) were accustomed to have an annual picnic on the Thames. These excursions, when favoured, as was generally the case, with fine weather, formed delightful reunions. The provision for the picnics was made conjointly by the Professor and the Assistant Professor of Physiology at University College, or, to speak more truthfully, by their wives. After the migration of the Sandersons to Oxford the river excursions were for a time continued, the London and Oxford parties meeting half-way. But as the numbers of the Society increased, expeditions of this kind were no longer possible and the river-picnic dropped out ${ }^{2}$.

1 The rules as altered are entered in the Minute Book.

${ }^{2}$ It was revived for once when the International Medical Congress met in London in 1913 (p. 150). On this occasion the Physiological Society-which ran the Section of Physiology-invited its foreign guests to an excursion on the Thames; but in place of the small boats which used to serve for the old river excursions a commodious launch was boarded at Tilehurst and took the party up river to Whitchurch, returning for lunch to the Caversham Bridge Hotel. Re-embarking after lunch, the party proceeded down river to Shiplake, returning for tea to the Hotel. And then to London for dinner: a long but enjoyable day. 
June 7th, 1884 (at Oxford). This was the first meeting of the Society to be held at Oxford, where Professor Burdon Sanderson was now established.

The following members were present at the dinner, which was held at Magdalen College: Professor Burdon Sanderson in the chair, Messrs W. B. Carpenter, E. A. Schäfer, D. Ferrier, E. Klein, A. Gamgee, F. J. M. Page, F. Gotch, C. H. Golding-Bird, W. H. Gaskell, and several guests (not specified). This was preceded by a scientific meeting. No business is recorded as having been transacted at the dinner.

November 8th, 1884 (at the Café Monico). This was the ninth Annual Meeting. Professor M. Foster in the chair. Fourteen other members attended, namely, John Marshall, Ferrier, Wooldridge, Pye, Roy, Bell, Cash, Lea, Page, Groves, Gaskell, McCarthy, D'Arcy Power and Yeo. $\mathrm{Mr}$ W. Heape was present as a guest introduced by Lea.

Mr W alter Heape (F.R.S. 1906) is the well-known embryologist.

At this meeting, besides the election of Committee, Dr W. H. Gaskell was elected Treasurer vice Mr G. J. Romanes, resigned; a cordial vote of thanks to Mr Romanes for his services being passed. The finances were reported as satisfactory but the printing of the Proceedings had greatly reduced the usual credit balance.

Twelve new members were elected as follows: W. Watson Cheyne, A. de Watteville, J. McGregor Robertson (Glasgow), G. A. Buckmaster (Oxford), V. A. H. Horsley, J. McWilliam, Sydney Ringer, E. F. Herroun (King's College), J. W. Barrett (King's College), E. B. Poulton (Oxford), Sidney Hickson (Oxford), W. Gardiner (Cambridge).

Dr J. McGregor Robertson was Lecturer in Physiology in the University of Glasgow, and assistant to Professor McKendrick: he was the author of a small Handbook of Physiological Physics.

Dr G. A. Buckmaster is Professor of Physiology in the University of Bristol.

Dr J. W. Barrett is now Sir James Barrett, C.M.G., a well-known ophthalmic surgeon in Melbourne.

Mr E. B. Poulton is Professor Poulton (F.R.S. 1889), Hope Professor of Entomology in Oxford.

Mr Sidney Hickson is Professor S. J. Hickson (F.R.S. 1895), who has lately retired from the chair of Zoology in the Owens College, Manchester. 
W. Gardiner is Dr Walter Gardiner (F.R.S. 1890), Fellow and Bursar of Clare College. He was awarded a Royal Medal of the Royal Society in 1898 for his work on Protoplasmic Continuity in Plants.

Dr Roy drew attention to the projected memorial to the late Professor Cohnheim, and invited subscriptions from members - the Society itself having no available funds. The members present immediately put down subscriptions to the amount of $£ 20$, and it was decided to invite absent members to join the list.

December 13th, 1884 (at University College). Were present: Professor Schäfer (in the chair), McWilliam, Ringer, Wooldridge, Sanderson, Lankester, Romanes, Horsley, Thane, McCarthy, Gotch, Hickson, Lea, Cheyne, Power, Yeo and Golding Bird—and as guests, Drs McMunn, Bennett, Phillip, Marcet, Dudley Buxton, Martin, Green and Halliburton.

Dr W. McIM unn, a graduate of Trinity College, Dublin, was a busy practitioner in Wolverhampton who devoted his leisure time to the examination and description of spectra of animal and vegetable colouring matters. His work was recognised as of a high order, and was frequently brought to the attention of the Society. He served in the South African War, 1889-92. He died in 1911.

Phillip is meant for Dr C. D. F. Phillips, who had been a physician in Manchester, but had retired from practice - the result of a railway injury. He was living in London, and working in the Physiological Laboratory of University College.

Dr Dudley Buxton was for many years anæsthetist to University College Hospital; he was at this time working in the Physiological Laboratory of University College. He has now retired.

Dr S. H. C. Martin (F.R.S. 1895), was also working in the University College Laboratory. He subsequently became Assistant Physician and ultimately Physician to University College Hospital, and succeeded Victor Horsley in the Chair of Pathology in University College. He died in 1924.

A suggestion, emanating from Dr Gamgee, that the Society should discuss points of interest concerning which differences of opinion existed was not received favourably by the members, a majority of whom were of opinion that such discussions ought not to be allowed to displace demonstrations.

February 14th, 1885 (at King's College). Mr Clinton T. Dent was in the chair; the other members present being Messrs Lea, Gaskell, Hickson, 
Cash, Cheyne, McWilliam, Groves, Page, McCarthy, Barrett and Yeo, as well as two guests, Dr R. H. Clarke and Dr Syne (probably Symes, see p. 93).

Dr Clarke is best known for his work on brain localisation as determined by destructive electrolysis with the aid of a very precise instrument devised by him for the purpose. He was working at this subject with Horsley. He died in 1926.

The only business was a discussion on methods of combating the anti-vivisectionist agitation by dissemination of certain papers. The matter was referred to the Association for the Advancement of Medicine, by Research.

March 21st, 1885 (at University College) ${ }^{1}$. Professor Burdon Sanderson was in the chair at the dinner: the other members present being Sydney Ringer, McWilliam, McCarthy, Schäfer, Thane, Page, Poulton and Herroun, as well as seven guests, namely, C. D. F. Phillips, Dudley Buxton, Sidney Martin, W. D. Halliburton, Rose Bradford, R. Meldola and W. M. Bayliss.

Dr Rose Bradford is now Sir John Rose Bradford, K.C.M.G., C.B., C.B.E., President of the Royal College of Physicians. He was at this time working with Bayliss in the University College Laboratory at the electrical changes of secreting glands.

Mr R. Meldola is Professor R. Meldola, F.R.S., an eminent chemist and biologist. He died in 1915 .

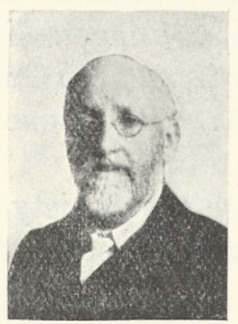

William Maddox Bayliss (F.R.S. 1903), who has just been mentioned as working with Bradford, was destined to become one of the most distinguished physiologists of the day. His investigations covered a wide field-vaso-motor nerves, secretion, physico-chemical problems in physiology, etc.-and were throughout marked by originality and accuracy. These qualities secured the awards successively by the Royal Society of a Royal Medal and of the Copley Medal, the last in 1922. He was knighted the same year. Much of Bayliss' work was performed in conjunction with others, e.g. that on the electrical changes accompanying secretion with Rose Bradford, and that on the action of the heart, on the secretion of the pancreas and on the movements of the intestines

1 The minutes of this meeting are in an unusual handwriting. 
with Ernest Starling, whose sister he married. His book on "General Physiology," familiar to physiologists, is characterised by its philosophical method of treating the subjects comprised under that term: it could only have been carried to a successful issue by one possessing the highest intellectual attainments. In 1912 the title of Professor of General Physiology was conferred upon him by the University of London. His untimely death in 1924 is still deplored not only by members of this Society-of which for many years he acted as one of the Secretaries (and for a short time as Treasurer)-but by physiologists throughout the world.

May 9th, 1885 (at Cambridge). Professor Foster was in the chair: the following also were present: Ringer, Pye-Smith, de Watteville, Gaskell, Barrett, D. McAlister, Roy, Lea, Gardiner, Groves, Yeo and Langley, besides nine guests. Of the latter may be especially mentioned $\mathrm{Mr}$ Coutts Trotter, Fellow and Vice-Master of Trinity College, Professor Haycraft and Dr Edkins.

Professor J. Berry Haycraft was Professor of Physiology in Mason College, Birmingham, and afterwards in University College, Cardiff. He died in 1922. Haycraft discovered the anti-coagulating action of hirudin.

Dr Edkins is now Professor of Physiology at Bedford College, London.

November 14th, 1885 (at Gatti's Restaurant, Strand). At this, the tenth Annual Meeting, Dr Donald McAlister was in the chair; other members present being Sanderson, Gaskell, Cash, Pye-Smith, Ringer, Klein, McWilliam, Wooldridge, Bell, Lea, Horsley, McCarthy, Page, Groves, Thane, Power and Yeo; also Dr Toms of the U.S.A. army as guest of the Chairman.

The Secretary reported that the constitution of the Society had undergone fundamental alteration, the effects of which were not yet fully felt ${ }^{1}$.

The Treasurer reported a credit balance of $£ 35$.

Eleven new members were elected. They are Walter Tyrell Brooks (Oxford), Frederick W. Mott, J. R. Green, C. A. McMunn, W. D. Halliburton, S. H. C. Martin, Alexander McAlister, C. S. Sherrington, Alexander Hill, J. M. Purser, B. W. Ransom. The list contains an unusual number of names of men who subsequently attained distinction.

1 This remark refers to the considerable increase in numbers and to the fact that the scientific meetings were now better patronised than the dinner meetings. 


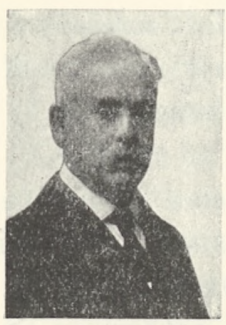

Dr Frederick W. Mott is the eminent pathological neurologist, afterwards Sir Frederick Mott, K.B.E., F.R.S. At this time he was working in the Physiological Laboratory of University College on conduction in the spinal cord; subsequently he became lecturer on Physiology, first at Liverpool, and afterwards at Charing Cross Medical School. When the London County Council decided to establish a laboratory in connexion with their Mental Hospital at Claybury, Mott was made the first Director. He was knighted in 1919 for his scientific eminence and his services during the War. He died on June 8th, 1926, at the age of 72.

Professor Joseph Reynolds Green (F.R.S. 1895) was at this time Senior Demonstrator in Physiology at the University of Cambridge. In 1902 he was elected Fellow and Lecturer of Downing College, Cambridge, and subsequently became Hartley Lecturer in Vegetable Physiology in the University of Liverpool. He died in 1914.

Dr C. S. Sherrington is now Sir Charles Sherrington, G.B.E., O.M., F.R.S., Waynflete Professor of Physiology in the University of Oxford. From the first he took a prominent part in the Society, but it is neither necessary nor appropriate here to give a narrative of his career, since he is fortunately still with us. Nevertheless an account of the history of the Society would be incomplete without mention of the fact that he was the first physiologist to occupy the position of President of the Royal Society (1920-1925). This unique distinction was commemorated by a dinner given to him by the members of the Society at the Café Royal on March 11th, 1921.

Dr Alexander Hill was working at this time in Foster's laboratory. Subsequently he became a Fellow, and eventually Master, of Downing College and Vice-Chancellor of the University of Cambridge. Later he was appointed President of University College, Southampton. He is now Secretary of the Universities' Bureau of the Empire.

Dr W. B. Ransom was working in Foster's laboratory. He afterwards joined his father in practice as a physician in Nottingham. He resigned from the Society in 1901 and died in 1907.

Dr J. M. Purser was at that time Professor of the Institutes of Medicine in Trinity College, Dublin, where he became subsequently Regius Professor of Physic. 
A letter of condolence was directed to be sent by the Secretary to the relatives of the late Dr W. B. Carpenter, an honorary member of the Society, who had recently died under tragic circumstances.

The minutes of the remaining meetings of this session (1885-6) show nothing of special interest. They were held at the usual places, King's College (December), University College (February), Oxford (March), and Cambridge (May). All were preceded by scientific gatherings in the respective laboratories, the proceedings at which are published in the Journal of Physiology.

November 13th, 1886 (at Gatti's Restaurant). This was the eleventh Annual Meeting. Dr Burdon Sanderson was in the chair, and other members present were Gaskell, Foster, Klein, McCarthy, Waller, Wooldridge, Ringer, Lea, Pye-Smith, Page, Mott, Thane, Bell, Power, North, Langley, Schäfer, Yeo and Groves. There were three guests, namely, Dr Savage, Dr Edkins and Dr Sanger Brown.

Dr George Henry Savage, afterwards Sir George Savage, was an eminent London psychiatrist. He died in 1921 at the age of 79 .

Dr Sanger Brown, an American psychiatrist from New York, is now at Chicago. He was at this time working with Professor Schäfer in the University College Laboratory at sensory localisations in the brain of the monkey.

After election of Committee and Officers, the following candidates were admitted to membership of the Society: E. M. Crookshank (King's College, London), William Ewart (London), William Marcet, E. Waymouth Reid (Cambridge), J. R. Bradford, J. Hughlings Jackson, F. A. Dixey (Oxford), C. D. F. Phillips, R. Norris Wolfenden (Cambridge), Sheridan Delépine, James Blake (London) and R. Milne Murray (Edinburgh).

Dr E. M. Crookshank was Professor of Comparative Pathology and Bacteriology in King's College.

Dr William Ewart was a London physician attached to St George's Hospital, interested in physiological questions.

Dr E. Waymouth Reid (F.R.S. 1898) is now Professor of Physiology at Dundee.

Dr J. Hughlings Jackson (F.R.S. 1898), is the famous neurologist who first described the symptoms produced by traumatic 
excitation of the cerebral cortex, known as "Jacksonian epilepsy." He was born in 1835. Appointed to the London Hospital in 1864 he served as Assistant Physician and Lecturer on Physiology until 1874, when he became full Physician. He occupied a similar position at the National Hospital for the Paralysed and Epileptic from 1863 to 1906. He was the first President of the Neurological Society, which is now merged into the Neurology Section of the Royal Society of Medicine. He died in 1911 at the age of 76 .

Dr F. A. Dixey (F.R.S. 1910), of Wadham College, Oxford, studied medicine at University College Hospital. He went with Burdon Sanderson to Oxford in 1883 as Lecturer on Histology.

Dr James Blake was at the time in practice in London. He afterwards went to California.

Dr R. Milne Murray was a physician in Edinburgh and Lecturer on Physiology in the extra-mural school.

The minutes of this meeting have not been signed and there are no minutes of a December meeting-which was generally held at King's College. But the King's College meeting appears to have been held in March (see p. 84) since the minute regarding it occurs after that of the February meeting, and is signed J. N. Langley, May 14, 1887. There was probably some entry made between the accounts of the November and February meetings but it has disappeared, four leaves having here been cut out of the Minute Book (cf. p. 48).

February 12th, 1887 (at University College). This is the next meeting mentioned in the minutes. Professor Schäfer was in the chair at the dinner: other members present were Foster, Power, Langley, Bradford, Gotch, Page, North, Gaskell, Ringer, Marcet, Horsley, Halliburton, S. Martin, Ransom, Pye-Smith, Lea and Yeo, and five guests, viz. E. P. France, S. Brown, F. Semon, Bevor (sic), Foster (?).

Mr E. P. France was research assistant to Professor Schäfer.

Dr Semon, afterwards Sir Felix Semon, the laryngologist, was working in the laboratory of University College, and later (with Horsley) at the Brown Institution. He was the founder of the Laryngological Society, now merged in the Royal Society of Medicine. He died in 1926 aged 72.

Dr C. E. Beevor (misspelt in the minutes) was working at the Brown Institution with Horsley, who had succeeded Sanderson there as Professor Superintendent. He became Physician to the 
National Hospital for the Paralysed and Epileptic and was President of the Neurological Society in 1907. He died in 1908.

The Secretary announced the death of Mr W. H. Waters of Manchester, who had been a member since 1882 .

It was decided to have a second meeting in each session for the election of new members.

No date is affixed to the minutes of the next meeting which was held at King's College - probably on March 12th. Dr Blake was in the chair and eight other members were present, viz. Foster, Schäfer, Bradford, North, Page, McMunn, Crookshank and Yeo; and Mr Liddell as guest.

May 14th, 1887 (at Cambridge). The dinner was in St John's College. Mr Langley occupied the chair; other members present were Foster, Purser, Gaskell, Bradford, Gardiner, Gotch, Green, Halliburton, A. Hill, Horsley, Lea, D. McAlister, Marcet, Poulton, Murray, Mott, Page, Phillips, Ransom, Roy, Schäfer, Sherrington, Thane and Yeo, as well as "several guests." No business was transacted, but it was agreed to accept an invitation from Professor Sanderson to meet at Oxford on July 2nd.

July 2 nd, 1887 (at Oxford). At this meeting, the date of which is omitted from the minutes, the dinner was held at Magdalen College with Professor Sanderson in the chair. Other members present were Foster, North, Halliburton, Page, Bradford, Delépine, Phillips, Mott, Martin, Ransom, Gotch, Buckmaster, Gaskell, Poulton, Brunton, Brooks, McAlister, Waller and $\mathrm{Yeo}$, and seven guests.

Of the guests the most noteworthy was Dr J. S. Haldane (F.R.S. 1897), whose name appears for the first but by no means the last time in the Society's minutes. Dr Haldane was elected a member at the next meeting.

November 12th, 1887. The twelfth Annual Meeting was held in Gatti's Restaurant, Strand ${ }^{1}$. Mr Henry Power was in the chair: the following were also present: Foster, Lea, McCarthy, D'Arcy Power, Gotch, Page, North, Groves, Langley, Delépine, Ringer, Pye-Smith, Mott, Phillips, Marcet, Gaskell, Wooldridge, Crookshank and Yeo.

1 The date has again been omitted, but the chairman in signing the minutes of the preceding meeting has added the above date to his signature. 
The Secretary reported the resignation of two members, Dr Barrett ${ }^{1}$ of Melbourne (p. 77) and Dr Bettany.

The Treasurer reported that there was a credit balance of $£ 100.16 s .9 d$. It was resolved to contribute $£ 20$ to the Donders Testimonial Fund.

The Secretary was instructed to put himself in communication with the Professor of Physiology at Bern with a view of instituting an international meeting of physiologists in that town during the summer session.

This was the first step in the direction of organising the Triennial International Congresses of Physiology. The first congress was however not held at Bern but at Basel in 1889 (see p. 91).

After election of the Committee, which consisted of Dent, Foster, Horsley, Langley, Lea, Pye-Smith, Sanderson, Schäfer, McKendrick and Waller, the following new members were elected to the Society: J. G. Adami (Cambridge), G. Haslam (Manchester), C. E. Beevor (London), J. S. Edkins (Cambridge), A. F. S. Kent (Manchester), J. S. Haldane (Oxford), H. Head (Cambridge), C. J. Martin (King's College, London).

Dr J. G. Adami, O.B.E. (F.R.S. 1905), the distinguished pathologist, was then working at Cambridge with Roy. In 1892, at the age of 30, he was appointed Professor of Pathology in McGill University, Montreal. In 1919 he was invited to Liverpool as Principal and Vice-Chancellor. He died in August, 1926.

Dr Stanley Kent was at this time Demonstrator of Physiology in Owens College. Later he became the first Professor of Physiology in the newly established Bristol University, but resigned that post in 1919 to undertake research work in connection with industrial fatigue.

Dr C. J. Martin (F.R.S. 1901), now Sir Charles Martin, C.M.G., is the Director of the Lister Institute at Chelsea. He was for some years Professor of Physiology in Melbourne.

Invitations to meet in December in the Bacteriological Laboratory in King's College, and in February at University College, were accepted.

February 11th, 1888 (at University College). Dr Sanderson was in the chair. The other members present at the dinner were Gaskell, Caton,

1 Dr Barrett rejoined the Society later (p. 110). 
Beevor, Halliburton, Lea, Head, North, McCarthy, Haldane, Edkins, Thane, Herroun, C. Martin, Bradford, Langley and Yeo, as well as five guests, namely, Dupuy, Dean, Arle(?), France and Ashdown.

The Secretary announced the resignation of Mr, later Sir, Francis Darwin, one of the original members.

Further steps were directed to be taken by the Committee in connexion with the Donders Testimonial Fund and the proposed International Physiological Congress, which it was suggested might be held in Bern in 1889 .

It was decided to entertain Professor Kühne at a special dinner meeting of the Society, on the occasion of his coming to deliver the Croonian Lecture at the Royal Society.

It was resolved to present our Proceedings to the Société de Biologie, Paris.

March 17th, 1888 (at Oxford). Dinner at Magdalen College, Professor Sanderson in the chair. Other members present were Messrs Gaskell, Schäfer, Horsley, Brooks, Mott, Page, McMunn, Buckmaster, Gotch, Romanes, Ewart, Haldane, Power, Phillips, Halliburton and Yeo, as well as sixteen guests. The latter included Dr Schönland, Messrs Thomson, Farmer, Balfour, Burch, Wilson, Harris, Doyne, Bayliss, Ashdown and the Vice-President of Magdalen.

Thomson is probably Professor Arthur Thomson, the Professor of Anatomy in Oxford.

Balfour is probably Professor Isaac Bayley Balfour, F.R.S.: at that time in Oxford, afterwards in Edinburgh. He died in 1922 .

Farmer is probably the eminent botanist, now Sir J. B. Farmer (see p. 123).

Dr G. J. Burch was an Oxford physicist, who was assisting Professor Sanderson in his experiments with the mercury electrometer. He himself made many experiments on Colour-Vision. $\mathrm{He}$ joined the Society in 1894. He died in 1914.

June 16th, 1888 (at Cambridge). The dinner was held in St John's College, Professor Foster in the chair. The following members were also present: Sir William Bowman, Lea, Brunton, Halliburton, D. McAlister, Gaskell, Roy, Langley, Schäfer, Bell, Bradford, Groves, Mott, Page, Ransom, and Yeo; as well as five visitors, namely, Messrs Gadow, Hare, Hunter, Shore and Wright. 
Mr Hans Gadow (F.R.S. 1892) is Lecturer on Advanced Morphology of Vertebrates in Cambridge.

Mr Wright is A. E. Wright, then an undergraduate, now Sir Almroth Wright, K.B.E., C.B., F.R.S. (p. 101).

The most notable figure was Sir William Bowman, who was now in his 72nd year. He was present as a guest at the inaugural dinner of the Society, and had been elected an honorary member in October, 1882.

Encouraging replies to the circular sent out regarding the meeting of an International Physiological Congress in 1889 having been received, the Committee was directed to assist the arrangements for such a gathering.

November 17th, 1888 (at King's College). This was the thirteenth Annual Meeting. Dr Pye-Smith occupied the chair at the dinner: the other members present were Schäfer, Crookshank, Bell, Groves, Lea, Gaskell, Mott, Power, Haldane, North, Sherrington, McCarthy, Page and Yeo, and two guests, Dr Copeman, introduced by Sherrington, and $\mathrm{Mr}$ H. K. Anderson, introduced by Haldane.

Dr S. Monckton Copeman (F.R.S. 1903) became Inspector to the Local Government Board and later to the Ministry of Health, which succeeded the Local Government Board in such of its functions as concerned Public Health.

Dr H. K. Anderson (F.R.S. 1907) was working in Foster's laboratory independently and in conjunction with Langley. $\mathrm{He}$ was Lecturer on Physiology in the University of Cambridge and a Fellow of Caius College. He is now Master of Gonville and Caius College. He was knighted in 1922.

The Secretary read his report regarding the meetings held in the past session, and also a letter from Professor Donders thanking the Society for the part they had played in furthering the testimonial to him on the occasion of his 70th birthday ${ }^{1}$.

The Treasurer's report showed a credit balance of $£ 120.3 s .11 d$.

The Committee reported that it had been arranged to hold the International Physiological Congress at Basel instead of at Bern, commencing on September 10th, 1889.

The new Committee having been elected, the following candidates for membership of the Society were chosen: Dr Sims Woodhead (Edinburgh), Dr L. E. Shore (Cambridge), Dr Hunter, Dr F. J. Allen (Cambridge).

1 This letter, in excellent English, is preserved in the minutes. 
Dr Sims Woodhead, afterwards Sir German Sims Woodhead, was at this time Director of the Royal College of Physicians' Laboratory in Edinburgh. In 1890 he was appointed to the charge of the Laboratories of the Conjoint Board of the Royal Colleges in London. From 1899 until his death in 1921 he occupied the chair of Pathology at Cambridge. He was actively engaged during the War in organising sanitary measures, and in inspecting laboratories in military hospitals.

Dr L. E. Shore, O.B.E., of St John's College, is a Lecturer on Physiology in the University of Cambridge.

Dr William Hunter is an alumnus of the University of Edinburgh. He was at this time John Lucas Walker scholar in Pathology at Cambridge. Later he became attached to Charing Cross Hospital, to which he is now Consulting Physician.

Dr F. J. Allen (Cambridge) was for a time Professor of Physiology in Mason College, Birmingham.

The Sub-committee on the Journal reported that the proprietors state that there is a considerable deficit on each volume, and suggest that each member should pay a subscription of $17 s .6 d$. per volume. It was decided to raise the annual subscription to $£ 1.5 s$., and of this to contribute $£ 1$ per annum to the Journal of Physiology, every member to receive a copy of each number as published. It was also decided to hold the Annual General Meeting in January instead of in November.

January, 1889 (at St Mary's Hospital Medical College). Up to the present, 1888, the scientific meetings had been held only at four centres, namely, University College, London; King's College, London; Cambridge and Oxford. But the Society accepted an invitation from Dr Waller to hold a scientific meeting in his laboratory at St Mary's Hospital Medical School.

The Secretary has omitted the day of the month from the minutes.

Dr Waller was in the chair at the dinner, which was at the Westbourne Restaurant; the other members were Sanderson, Stirling, Page, Mott, Gotch, Beevor, Hickson, Reid and Shore, and two guests, Mr Jessop and Mr T. W. Shore (both of St Bartholomew's). No business was transacted.

February 9th, 1889 (at University College). At this meeting Professor Schäfer was in the chair, and there were present sixteen other members, namely, Sanderson, Foster, Gaskell, Phillips, Lea, Halliburton, Haldane, 
Langley, Horsley, Gotch, Page, McCarthy, Golding-Bird, Edkins and Yeo; and nine guests. Of the latter the most noteworthy was Mr Boyce.

Mr Rubert Boyce (F.R.S. 1902) was a young Ulsterman, who studied at Queen's College, Belfast, and at University College, London, and was for a time Assistant in the Physiological Laboratory there. He subsequently developed in Pathology and in 1894 was appointed Professor of that subject in Liverpool, the University College of which was in process of conversion into an independent University. He had a singular faculty for getting money out of the business people in Liverpool for the establishment and endowment of new laboratories, and it is related that there was no getting him out of an office without the promise of a substantial sum in aid of the fund he was advocating. The Liverpool School of Tropical Medicine owed much to Boyce's efforts, not only in obtaining funds, but in organising expeditions to the Tropics with the view of studying and fighting tropical diseases. He was knighted in 1906. Although he suffered a stroke of paralysis in that year, he in no way relaxed his energies, but carried on in spite of all disadvantages. He died in 1911 at the age of 48.

March 9th, 1889 (at Cambridge). On this occasion Dr Donald McAlister occupied the chair, and there were fourteen other members present, namely, Gaskell, Lea, Hunter, Wooldridge, Adami, Horsley, Langley, C. J. Martin, Sherrington, Green, Shore, Alex. McAlister, Groves, Yeo and Woodhead ${ }^{1}$, and five guests. Included amongst the latter was $\mathrm{Mr}$ Hardy of Caius College.

Mr W. B. Hardy (F.R.S. 1902), Lecturer on Physiology in Cambridge and Fellow of Caius College, acted as one of the Secretaries of the Royal Society from 1915 to 1925 , in which year he received the honour of knighthood. Mr Hardy became a member in 1892. He is now Director of the Food Investigation Board and is probably the only person who has been invited by the Royal Society to deliver both the Croonian Lecture (Biology) and the Bakerian Lecture (Physics).

May 11th, 1889 (at King's College). Mr E. F. Herroun was in the chair; seven other members were present, namely, Sherrington, C. J. Martin, Shore, Halliburton, Beevor, Ewart and Yeo. There were also

1 Put down as a guest in the minutes, but this must be a mistake for he had been elected a member in November, 1888. 
three guests, one of whom was Dr Copeman, introduced by Sherrington, and another Mr Starling, who was introduced by C. J. Martin.

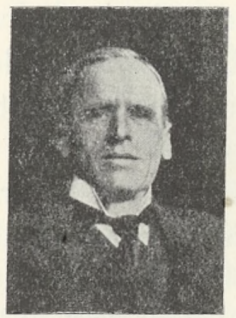

Afterwards Professor E. H. Starling, C.M.G., F.R.S., Foulerton Research Professor of the Royal Society. Previously Jodrell Professor of Physiology in University College, London. This is the first mention of Professor Starling's name in the minutes. $\mathrm{He}$ was Secretary of the Society from 1896 to $1900^{1}$.

The Society having been notified of the death of Professor Donders, the Secretary was directed to express to his friends the sense of the Society of the loss physiological science had thereby sustained.

It was agreed to subscribe $£ 5.5 s$. out of the funds of the Society to the "Bowman Testimonial."

June 29th, 1889 (at Oxford). The dinner was at Magdalen College, with Professor Sanderson in the chair, nineteen other members being present, namely, Groves, Brooks, Haldane, Horsley, Beevor, Waller, Allen, Poulton, Murray, Woodhead, C. J. Martin, Sherrington, Hunter, Page, Halliburton, Mott, Bradford, Delépine and Gotch, and eleven guests, namely, Chapman, MacFadyen, Ballance, Vally(?), Boyce, Spencer, Fisher, Thomson, Farmer and Burch, and Professor Thompson of New York.

MacFadyen is probably Dr Allen MacFadyen, who was Bacteriologist at the Lister Institute.

A resolution expressing "the sincere regret of the Society at the premature death of one of the most distinguished of its younger members," Dr Leonard Wooldridge, was adopted, and the Secretary was directed to express its condolence to his widow.

November 9th, 1889 (at Gatti's Restaurant). This was the fourteenth Annual Meeting. There were present Dr Pye-Smith in the chair, and nineteen other members, namely, Gaskell, Klein, McCarthy, Page, Pye, C. J. Martin, Gotch, Horsley, Mott, Schäfer, Buckmaster, Kent, Milne Murray, S. Martin, Haldane, Edkins, Sherrington, Lea and Yeo, but no guests.

1 Starling's death on May 2nd, 1927, when on a voyage to Jamaica for his health, occurred whilst this account of the Society was passing through the Press. A full and sympathetic obituary notice, by Dr C. J. Martin, is published in the British Medical Journal of May 14th, 1927. 
The Secretary reported that during the past year the Society had lost two members by death (Wooldridge and McDonnell), and one (Moseley) by resignation, and that Dr Blake's address was uncommunicated (p. 83).

This meeting was important for several reasons:

1. It was reported by the Treasurer that the finances of the Societyin spite of the rise in the amount of subscription-were becoming embarrassed on account of the large amount which had to be paid to the proprietors of the Journal for printing the Society's Proceedings. It was suggested that the proprietors might themselves undertake this charge, since the Proceedings of the Society formed a valuable addition to the Journal, and the Treasurer was directed to try and arrange this matter satisfactorily. But neither now nor at any other time was the Society able to make a satisfactory arrangement regarding this matter; the difficulty had always to be met by raising the subscription and giving a larger subsidy to the Journal ${ }^{1}$.

2. It was reported by the Secretary that since the last meeting the First International Physiological Congress had been held at Basel and was considered a conspicuous success. It was attended by 124 members, of whom seven were American, seven Austrian, six Belgian, one Dutch, twenty-four German, nineteen English ${ }^{2}$, eighteen French, ten Italian, one Portuguese, one Roumanian, four Russian, three Swedish and twenty-three Swiss.

Since this first Congress, which, as has been narrated, was initiated by the action of the Physiological Society, there have been eleven others, one every three years. But between 1912 and 1920 there was a hiatus owing to the Great War. To the Congress of 1920, which was held in Paris, only members of the allied nations were invited. To that held in Edinburgh (in 1923) an invitation was sent out again to all nationalities, and 516 members were enrolled. Twenty-one nations were represented; about half the total number belonged to Great Britain and Ireland. In the Congress held in Stockholm in August 1926 the number rose to over 600. These figures are eloquent of the spread of the interest in Physiology throughout the world since the first Congress at Basel in 1889.

3. This was the first meeting of the Society to receive an invitation

1 Eventually, as already mentioned, the Journal was acquired by the Society; but not until January, 1926.

2 The Secretary means "British." Himself Irish, he had no idea he might be giving offence to members of the Society hailing from north of the Tweed. 
to meet elsewhere than in London, Oxford, or Cambridge. Dr Milne Murray, of Edinburgh, stated that he had been officially requested personally to urge the acceptance of an invitation from the Royal College of Physicians of Edinburgh to meet in their Hall in the following July. The Secretary stated that he had also received invitations from Professor Rutherford of the University of Edinburgh, and from Professor McKendrick of the University of Glasgow, to meet in their respective laboratories. The Secretary was directed to accept with pleasure the invitation of the Royal College of Physicians; to express to Professor McKendrick the hope that members might on their visit to Scotland find an opportunity of visiting his laboratory, and to Professor Rutherford their inability to accept his invitation, and to express the hope that they would be able to count on his co-operation, and have the privilege of visiting his laboratory.

4. The fourth item of interest at this meeting was the resignation of Professor Yeo from the Honorary Secretaryship, which he had held from the time of the formation of the Society. Although pressed to remain, his resignation was final, since he had decided to give up his chair at King's College and to reside in the West of England. The Committee recommended as his successor in the Secretaryship Dr C. S. Sherrington, who was at this time Lecturer on Physiology at St Thomas's Hospital, a recommendation which was unanimously approved.

The election of members to the Committee resulted as follows: M. Foster, F. Gotch, W. D. Halliburton, J. N. Langley, A. S. Lea, F. W. Mott, F. J. M. Page, P. H. Pye-Smith, J. S. Burdon Sanderson and E. A. Schäfer, with W. H. Gaskell as Hon. Treasurer and C. S. Sherrington as Hon. Secretary. At the ballot for new members the following were elected: R. Stockman, D. Noël Paton, T. W. Shore, H. E. Wingfield, G. Cunningham, H. P. Dean, C. W. Mansell-Moullin, W. Hale White, S. M. Copeman, H. Lewis Jones and J. Griffiths.

Dr Stockman is Professor of Materia Medica in Glasgow.

Dr D. Noël Paton (F.R.S. 1914), is Professor of Physiology in Glasgow, where he succeeded McKendrick in 1906.

Dr T. W. Shore, O.B.E., was for some years Lecturer on Biology at St Bartholomew's Hospital and Warden of the Medical College; of which he is now Dean.

Dr H. E. Wingfield was a Demonstrator in Physiology in Cambridge. He became Physician to the Royal Hants County Hospital in Winchester. $\mathrm{He}$ has devoted special attention to hypnotism. 
Mr H. P. Dean, F.R.C.S., was working at University College Laboratory. He is now Consulting Surgeon to the London Hospital.

Mr Mansell-Moullin, O.B.E., was also afterwards Surgeon to the London Hospital.

Dr W. Hale White is now Sir W. Hale-White, K.B.E., Consulting Physician to Guy's Hospital. He was at that time Lecturer on Materia Medica in Guy's Hospital Medical School and Assistant Physician to Guy's Hospital.

J. Griffiths is probably. Mr Joseph Griffiths, C.M.G., Surgeon to Addenbrooke's Hospital, author of various Anatomical and Physiological papers in the Journal of Anatomy and elsewhere.

December 14th, 1889 (at St Mary's). At the dinner held in the Westbourne Restaurant, the members present were Dr Waller, chairman, Halliburton, Mott, Haldane, Page, Copeman, Hunter, Adami, Martin and Sherrington, and as guests Messrs Ashdown, Hobhouse, Starling, Stewart, Hankin and Symes.

Dr Ashdown had been Professor Rutherford's assistant in Edinburgh but was now working in the Physiological Laboratory at University College.

Stewart is probably Dr G. N. Stewart (p. 94).

Symes is Mr W. L. Symes, who was Dr Waller's assistant at St Mary's Hospital Medical School and afterwards at the University of London; now Professor of Physiology at the Royal Veterinary College and Lecturer on Histology at St Thomas's Hospital Medical School.

There was some discussion as to the time of beginning the scientific meetings. It was decided to leave this to be arranged with the director of the laboratory where the meeting was to be held, "as the rules of the Society ignore any regulations of the proceedings of members previous to the meeting for dinner."

The question of contributing to a testimonial to Professor Holmgren was brought up by a circular letter from Professor M. G. Blix, but it seemed that the application arrived too late to be responded to, and the Society could only now express its high appreciation of the Swedish Professor's work.

The minutes are signed

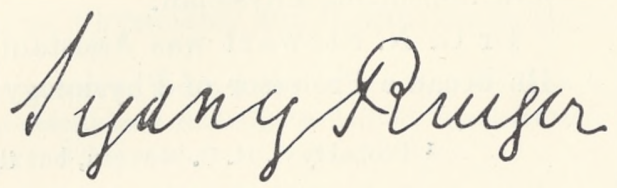


February 15th, 1890 (at University College). This was the Annual Meeting. Dr Sydney Ringer was in the chair; other members present were Burdon Sanderson, Schäfer, Gaskell, Langley, Lea, Mott, Halliburton, Phillips, Waller, Hale White, Page, Martin'1, Gotch, Haldane, Head, Hunter, Dean, Ransom, Cunningham, Copeman and Sherrington.

The following new members were elected: H. H. Ashdown, W. M. Bayliss, A. Lingard, J. Everett Millais, Sir William Roberts, Marc Armand Ruffer, J. Harrington Sainsbury, E. H. Starling, G. N. Stewart, E. H. Whitfield and F. Dawson Williams.

Dr Alfred Lingard was at this time (1900-1907) bacteriologist to the Indian Government.

Mr Millais was the son of the Academician. He assisted Romanes in carrying out experiments on pangenesis.

Sir William Roberts was educated at Mill Hill School and at University College, London, where he entered as a medical student in 1849 and came under Sharpey's influence. He took his M.D. at the University of London in 1854, in which year he was appointed House Surgeon to the Manchester Infirmary, and in the following year, at the age of 25, Physician and Lecturer in Anatomy and Physiology in the Owens College School of Medicine. When the Victoria University was established he became the first Professor of Medicine. He afterwards settled in London. He was elected F.R.S. in 1877 and was knighted in 1885. He wrote on various physiological subjects, especially spontaneous generation, the histology of the blood, digestive ferments and the condition of uric acid in the urine. He was Croonian and Lumleian Lecturer and Harveian Orator to the Royal College of Physicians. He died in 1899.

Dr, afterwards Sir Armand, Ruffer, an alumnus of University College, was a distinguished bacteriologist who was for a time Professor of Bacteriology in Cairo and eventually became Head of the Egyptian Health Service (1901). He was killed at sea during the War by the torpedoing of a ship in which he was travelling.

Dr Harrington Sainsbury was at this time working with Sydney Ringer in the Physiological Laboratory of University College. He became Physician to the Royal Free Hospital and is now Consulting Physician.

Dr G. N. Stewart was Assistant to Rutherford in Edinburgh. He became Professor of Physiology in the Western Reserve Uni-

1 Probably S. H. C. Martin, but the initials are not given. 
versity, Cleveland, Ohio, and is still attached to that University as Professor of Experimental Medicine.

Dr F. Daws on Williams was at that time working in the Physiological Laboratory of University College. He is now Sir Dawson Williams, Chief Editor of the British Medical Journal.

March 15th, 1890 (at Cambridge). The scientific meeting was held in the Pathological and Physiological Laboratories and the dinner in Caius College.

Professor Roy occupied the chair. There were twenty-eight members and four guests ${ }^{1}$.

On the motion of Professor Foster a vote of congratulation on the election of Professor Halliburton to the chair of Physiology at King's College was carried by "general acclamation in the most hearty manner possible." Professor Halliburton thanked the members for the way in which the proposition had been received.

Professor Schäfer moved a vote of thanks to the Fellows of Caius College for lending their Combination Room for the dinner. Dr Sheridan Lea stated in reply that "the College was only too pleased to see the Physiological Society under the roof that William Harvey had sat beneath."

May 10th, 1890 (at King's College). At this meeting there was again a large attendance. The principal business at the dinner, at which Professor Halliburton occupied the chair, was the presentation from the Society to the former Secretary, Professor Yeo, of a piece of silver plate in recognition of his services since its formation. The gift was accompanied by "a short and felicitous speech" by Professor Foster, and suitably acknowledged by the recipient.

June 28th, 1890 (at Oxford). The dinner meeting was held in the Junior Common Room of Magdalen College. Professor Burdon Sanderson occupied the chair. There were no fewer than thirty-six members and guests present. The visit to Scotland was discussed. Professor McKendrick had written to intimate that he would not at that time be able to receive a visit from the Society and it was eventually agreed to hold a scientific meeting in Edinburgh in the forenoon of July 25th in the Laboratory of the Royal College of Physicians, and in the afternoon in

1 The number of members and guests present at the meetings is becoming too large to be given each time and will in the further descriptions generally be omitted, especially since the members and guests are often no longer differentiated in the Minute Book. 
the Laboratory of the University: although there was a good deal of opposition manifested to the last part of the resolution. Thirty-two names had been sent in as desiring to visit Edinburgh.

No account of the Edinburgh visit is given in the minutes although it was certainly held. It is therefore to be concluded that it was not regarded as a formal meeting of the Society.

November 8th, 1890 (at the Conjoint Laboratories). The Society met for the first time for its scientific work in the Conjoint Laboratories of the Royal College of Physicians of London and of the Royal College of Surgeons of England on the Embankment. Dr Sims Woodhead, who was at that time Director of the Laboratories, occupied the chair at the dinner, which was held in Simpson's Restaurant, Strand; there were thirty-one other members and guests present.

Dr Foster gave notice that at the next meeting he wished to bring before the Society the question of the advisability of altering the Rules of the Society so as to admit of the election of a President. The terms of his motion and the requisite changes proposed in the Rules were written out by him; the Ms. is preserved in the Minute Book.

December 13th, 1890 (at St Mary's). At this meeting, which was held, for scientific purposes, in Dr Waller's Laboratory, and for dinner and business at the Westbourne Restaurant with Dr Waller in the chair and twenty-seven other members present, Professor Foster was unable to be present. The motion standing in his name was however brought forward on his behalf by Dr Gaskell, and seconded by Dr L. E. Shore. When the matter came to the vote the numbers pro and contra were equal (nine on each side); the chairman gave his casting vote against the proposition. A considerable number of members abstained from voting.

It would appear that the matter has never been reconsidered by the Society. It was in many respects a wise proposition; for the Society was no longer a dining club, but had grown into an important organisation and should have been formally constituted as a Scientific Society. There is little doubt that if Foster himself had been present his motion would have been carried, to the benefit of the Society and of Physiology in general in this country. For without incorporation or charter the Society cannot legally hold property or receive gifts or legacies, nor is it recognised by public bodies. A striking example of this was given at the celebration of the 250th anniversary of 
the Foundation of the Royal Society when the Physiological Society was the only Scientific Society which was not invited to send representatives to the celebration, although the relations between Physiology and the Royal Society have from the very beginning of the latter been particularly intimate; it would therefore have been natural for the Physiological Society, as such, to have taken a prominent part in the attendant ceremonies.

January 17th, 1891 (at Charing Cross). This was the fifteenth Annual Meeting. The scientific meeting was at the Medical School of Charing Cross Hospital, and the dinner meeting at Gatti's Restaurant under the chairmanship of Dr F. W. Mott. Thirty-one other members were present.

The Treasurer reported a satisfactory balance, but there is no balance sheet in the minutes, and no formal report by the Secretary.

The death of Mr John Marshall, F.R.S., one of the Honorary Members, having been reported, the Secretary was directed to transmit to $\mathrm{Mr}$ Marshall's relatives the sympathy expressed by the Society.

The Committee and Officers having been appointed, the following new members were then balloted for and declared elected: J. Batty Tuke, Grainger Stewart, T. D. Bokenham, E. H. Hankin, H. D. Rolleston, E. L. Meyer, W. Spencer, W. L. Dickinson, L. Hill, Alexander Bruce, W. L. Symes, Anderson Stuart and J. B. Haycraft.

Dr, afterwards Sir, J. Batty Tuke was an eminent Edinburgh alienist, at one time President of the Royal College of Physicians, Edinburgh.

Sir Thomas Grainger Stewart was Professor of Medicine in Edinburgh.

Dr Hankin was a distinguished pathologist and bacteriologist, who later took up work in India.

Dr H. D. Rolleston is now Sir Humphry Rolleston, Bart., K.C.B., Regius Professor of Physic in the University of Cambridge. He was previously Physician to St George's Hospital and President of the Royal College of Physicians of London.

Dr Leonard Hill (F.R.S. 1907) was at this time an Assistant in the University College Laboratory. Later he became Professor of Physiology at the London Hospital Medical College; and is now Director of the Department of Applied Physiology in the National Institute of Medical Research. Hill was one of the Secretaries of the Society from 1896 to 1903.

$\mathrm{PH}$. 
Dr Alexander Bruce was a distinguished neurologist and physician in Edinburgh. He was the author of an important, finely illustrated monograph on the Mid-Brain. He died in 1911.

February 14th, 1891 (at King's College). Special General Meeting. Professor Halliburton took the chair at the dinner. No fewer than forty-four members and guests were present.

As the list gives a good sample of those who attended the meetings about this time, it may be of interest to append the names. As entered in the minutes they are: F. J. Allen, W. M. Bayliss, C. E. Beevor, Jeffrey Bell, J. R. Bradford, T. Lauder Brunton, Watson Cheyne, S. M. Copeman, F. W. Crookshank, G. Cunningham, H. P. Dean, S. Delépine, D. Ferrier, Michael Foster, F. Gotch, J. S. Haldane, W. D. Halliburton, H. Head, E. F. Herroun, L. Hill, W. Hunter, Jackson ${ }^{1}$, Johnson ${ }^{2}$, Jones ${ }^{3}$, W. Marcet, C. J. Martin, S. H. C. Martin, Everett Millais, F. W. Mott, F. J. M. Page, C. E. Penrose $^{4}$, C. D. F. Phillips, P. H. Pye-Smith, Sydney Ringer, J. S. Burdon Sanderson, E. A. Schäfer, C. S. Sherrington, T. W. Shore, W. Spencer ${ }^{5}$, E. H. Starling, G. N. Stewart, W. L. Symes, A. D. Waller, Sims Woodhead.

The following were, at this meeting, elected members of the Society: Theodore Dyke Acland, Rubert W. Boyce, J. Lorrain Smith, Howard Tooth.

Dr Theodore Dyke Acland (see p. 70) is now Consulting Physician to St Thomas's Hospital, and to the Hospital for Diseases of the Chest, Brompton.

Dr James Lorrain Smith (F.R.S. 1909) was successively Professor of Pathology in the Universities of Belfast and of Manchester, and now occupies the same position in the University of Edinburgh.

Dr How ard Tooth was a distinguished neurologist and physician in London who worked on the structure and functions of the brain in monkeys. He died in 1925.

Various modifications in the rules - of which notice had been given at the preceding meeting-were moved and agreed to. One was to sub-

1 Probably Hughlings Jackson.

2 A guest, perhaps Dr Johnson, Physician to King's College Hospital.

${ }^{3}$ Probably E. Lloyd Jones.

4 A guest. Dr Penrose was a distinguished alumnus of University College; afterwards Physician to St George's Hospital.

5 Probably Mr W. G. Spencer, Lecturer on Physiology, and subsequently Surgeon to Westminster Hospital. 
stitute May for February as the second meeting at which new members might be elected.

March 21st, 1891 (at University College, London). Thirty-two members and guests were present at the scientific meeting. Demonstrations and communications were made by Ringer, Bayliss, Bradford, Starling, Schäfer and G. N. Stewart.

At the dinner in the evening Dr Ringer was in the chair. The following resolution, proposed by Professor Schäfer and seconded by Dr Waller, was adopted: "That in the opinion of this Society it is important in the interests of teaching of Physiology that, as recommended by the General Medical Council, a large part if not the whole of the additional year which is to be added to the medical curriculum should be devoted to Elementary Physics, Chemistry, and Biology." It was further moved by Professor Schäfer, seconded by the Secretary and agreed, that the Committee of the Society should consist of fifteen in place of ten members, and that one of the members should be appointed to act as Chairman.

May 9th, 1891 (at Cambridge). After a meeting for demonstrations held in the Physiological Laboratory members repaired for dinner to St John's College. Dr Gaskell occupied the chair; there were thirty-eight other members and guests present. Amongst these the name of Bateson is prominent.

Mr William Bateson (F.R.S. 1897), son of the Rev. W. H. Bateson, Master of St John's College, Cambridge, from 1857 to 1881, was an eminent authority on Mendelian principles of inheritance. He worked chiefly with plants, and was Director of the John Innes Horticultural Institution, Merton, Surrey. He was awarded the Darwin Medal of the Royal Society in 1904. He was President of the British Association during its visit to Australia in 1914. He died in February, 1926.

The following occurs in the minutes: "The term of occupation of the chair having been extended on the motion of Mr D'Arcy Power, $\mathrm{Mr}$ Gotch asked for information concerning the arrangements for the [second] International Congress of Physiology for 1892." Dr Gaskell supplied such information as he possessed.

June 20th, 1891 (at Oxford). Twenty-three were present at the scientific meeting, and thirty-three at the dinner in Magdalen College-with Professor Burdon Sanderson in the chair. Dr Cunningham of New York 
is mentioned as a guest. After dinner a conversation took place regarding the recording of the names attending the scientific meetings.

"It was considered well that some record of the attendance at the Demonstrations of the Society should be kept ${ }^{1}$, although the business of the Society which commences with dinner at half past six o'clock is the only part of the proceedings of the Society which is recognised by its Statutes."

The arrangements for the International Physiological Congress of 1892 were again under discussion at this meeting. There seemed to be a general preference for Switzerland as the most appropriate country and the Secretary was requested to communicate with Professor Kronecker of Bern regarding a meeting in his Institute.

November 14th, 1891 (at St Mary's). Thirty-five were present at the scientific meeting but only fifteen at the dinner, Dr Hughlings Jackson being one. Dr Waller was in the chair.

The Secretary having reported that no reply had been received from Professor Kronecker, a letter (inserted in the Minute Book) was read from Professor Paul Heger suggesting a meeting at Brussels of the "Comité directoire" of the Congress to discuss the place and time for the Congress of 1892. On the motion of Professor Foster the members present agreed to suggest Brussels as an appropriate place and the end of August or the beginning of September as an appropriate time.

December 12th, 1891 (at the Conjoint Laboratories of the Royal Colleges). Dr Sims Woodhead was in the chair: there were present thirty-seven members and two guests. At the dinner at Simpson's Restaurant twenty members and five guests were present.

Amongst the latter was Dr René Du Bois-Reymond of Berlin (son of the celebrated Professor of Physiology) and Mr Howard Mummery, an eminent authority on the structure of the teeth, the discoverer of nerve-fibrils in the dentinal tubules (died 1926).

The delayed letter from Professor Kronecker relating to arrangements for the next International Congress was read and the Secretary was instructed to communicate with the International Committee (Comité directoire) regarding the time of meeting of the Congress and especially to ensure that it might not clash with the meeting of the British Association in Edinburgh.

1 This expression of opinion does not seem to have been acted upon with any regularity. 
On the motion of Dr Waller a resolution was passed deprecating the shortening of the course of Physiology in the medical curriculum.

January 20th, 1892 (at Charing Cross Medical School). This was the Annual Meeting. The dinner was at Gatti's Restaurant. Dr Mott occupied the chair; there were also present twenty-seven members and three guests.

The Committee (now fifteen in number) having been elected, the following new members were balloted for and declared elected: J. W. Washbourn, E. Lloyd Jones, F. H. Edgeworth, A. de Burgh Birch, W. B. Hardy, P. T. Beale, T. G. Brodie, A. E. Wright, G. Cartwright Wood (bacteriologist), A. H. Tubby (orthopædic surgeon), J. H. Parsons, J. Randle Leigh, E. C. Stirling.

Dr Washbourn was Pathologist and Assistant Physician to Guy's Hospital. He was working with J. S. Haldane and W. Hale White on the subject of animal calorimetry.

Dr E. Lloyd Jones was a pathologist working with Roy at Cambridge.

Dr F. H. Edgeworth was working in the Cambridge Laboratory. He is now Physician to the Royal Infirmary, Bristol.

Dr de Burgh Birch was for many years Professor of Physiology at Leeds.

Dr P. T. Beale, F.R.C.S., was Assistant in Physiology at King's College.

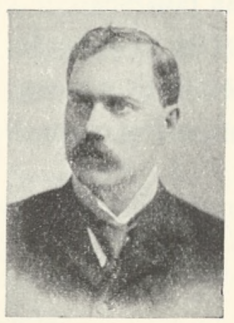

DrThomas Gregor Brodie (F.R.S.1904) was at that time Assistant in the Physiological Laboratory of King's College. Subsequently he became Lecturer at St Thomas's Hospital, Director of the Conjoint Laboratories, Lecturer at the London School of Medicine for Women and at the Royal Veterinary College, and Superintendent of the Brown Institute. In 1908 he was appointed Professor of Physiology at Toronto. He was distinguished both for the ingenuity of his methods and for the accuracy of his observations. His work embraced a great variety of subjects: much of it was published in conjunction with other workers. He served at the commencement of the War in the Canadian Medical Service. He died in August, 1916.

Dr A. E. Wright, now Sir Almroth Wright, K.B.E., C.B., F.R.S., was working at this time in the Conjoint Laboratories on Blood- 
Coagulation. He was Professor of Pathology at Netley from 1892 to 1902, when he became Pathologist at St Mary's Hospital.

Mr J. H. Parsons, now Sir John Parsons, C.B.E., F.R.S., was at that time Sharpey Scholar and Assistant in the Physiological Laboratory of University College. Later he directed his attention mainly to the physiology of the eye. He is now Ophthalmic Surgeon to University College Hospital and Surgeon to the Royal London Ophthalmic Hospital.

Dr Randle Leigh was Demonstrator of Physiology in Liverpool. Dr E. C. Stirling (F.R.S. 1893) who was Professor of Physiology in Adelaide, was knighted in 1917. He died in 1919.

The Treasurer having reported that the financial position of the Society was less satisfactory, resolutions were put and carried having for their object the diminution of the amount the Society was contributing to the Journal and to the cost of printing the Proceedings (but nothing resulted therefrom).

A resolution by Dr Waller that the first F.R.C.S. examination in Physiology exercises an unfavourable influence on the sound teaching of the subject was put and carried, and on the motion of Professor Sanderson a special committee was appointed to approach the College of Surgeons on the matter.

A letter from the Registrar of the Royal College of Physicians was before the meeting pointing out that the new regulations regarding attendance in courses of Physiology and Practical Physiology tended rather to increase than to diminish the length of these courses.

A letter to Professor Foster from Professor Holmgren of Upsala, the President of the Comité directoire of the International Congress, was also read and its propositions as to time and place of meeting approved ${ }^{1}$.

February 13th, 1892 (at University College). Communications were made at the scientific meeting by J. H. Parsons, J. Risien Russell, J. R. Bradford, W. Marcet and C. S. Sherrington.

At the dinner Sir William Roberts occupied the chair; twenty-two other members and guests were present.

Notice of certain proposed alterations in the rules was given by Professor Horsley and Dr Waller for the next meeting.

Dr Waller communicated an interim report from the special committee appointed to consider changes in the examination in Physiology for the F.R.C.S.

1 This letter has not been preserved. 
March 12th, 1892 (at King's College). At the scientific meeting communications were made by Young, Hewlett, Brodie, Beale, Wright, Mott, Tubby, Hopkins and Halliburton. The last named took the chair at the dinner; there were twenty other members and guests present.

A discussion took place on the report of the special committee (see p. 102) as to the best way to approach the College of Surgeons regarding the Physiology examination for the F.R.C.S. A letter was read which had been drawn up by the special committee appointed in January. This letter was referred back to the special committee in consequence of suggestions made by the former Secretary, Dr Yeo-who had had a long experience in this examination, and who pointed out a better way of arriving at the result desired.

Dr Waller moved that the constitution and rules of the Society be referred to the Committee for revision and report, five additional members being added to the Committee for the purpose. This was adopted.

A letter from Professor Exner to Professor Foster asking for assistance towards a memorial to the late Professor v. Brücke was circulated.

May 14th, 1892 (at Cambridge). Professor Foster was in the chair at the dinner, which was held in Caius College. There were forty-three members and guests present. Amongst the latter was Professor, afterwards The Rt Hon. Sir Clifford, Allbutt, K.C.B., F.R.S., Regius Professor of Physic in the University.

Allbutt seems never to have joined the Society, but was always a firm friend to Physiology and physiologists. He died, universally regretted, in 1925, at the advanced age of 88 . He retained to the last the full exercise of his faculties, and continued to perform his duties as Regius Professor until very shortly before his death. His biography belongs to the History of Medicine.

The following new members were elected: Dudley W. Buxton, Vincent D. Harris, J. Howard Mummery, C. A. Ballance, F. G. Hopkins, R. T. Hewlett.

Mr C. A. Ballance was working with Sherrington at St Thomas's Medical School. He became Surgeon to St Thomas's Hospital, and is now Sir Charles Ballance, K.C.M.G., Consulting Surgeon to the Hospital. He was appointed Surgeon to the National Hospital for the Paralysed and Epileptic, in succession to Sir Victor Horsley, and was chosen last year as the first President of the Society of British Neurological Surgeons. 
Dr F. G. Hopkins is now Sir Frederick Hopkins, F.R.S., Professor of Biochemistry at Cambridge.

Dr R. T. Hewlett is now Professor Hewlett, Director of the Bacteriological Laboratory of King's College, London.

June 25th, 1892 (at Oxford). The dinner was held at Magdalen College, Professor Burdon Sanderson in the chair. Thirty-five other members and guests were present.

Amongst the names of the guests is that of the present Treasurer, Dr M. S. Pembrey (F.R.S. 1922), now Professor of Physiology at Guy's Hospital; it appears in the Minute Book for the first time. Dr Pembrey was Acting Treasurer from October 1924 to March 1925, when he became Treasurer in succession to Sir William Bayliss.

The Chairman proposed that in view of the vacancies in the list of Honorary Members of the Society, caused by the death of Mr John Marshall and more recently of Sir William Bowman, new names should now be added to the list, and offered those of Professor Émil Du Bois-Reymond, Professor Chauveau and Sir Joseph Lister. These "were accepted by the meeting and elected by show of hands. Dr Waller remarked on the inadvisability of taking this step without giving previous notice."

November 12th, 1892 (at St Mary's Hospital Medical School). Communications were made by Boyce, Mott, Wright, Schäfer and Kent. The dinner was at the Westbourne Restaurant with Dr Waller in the chair: forty-seven other members and guests were present.

Amongst the guests may be especially mentioned Dr Kanthack, who was at this time Demonstrator of Pathology in the University of Liverpool, and after that Director of the Pathological Department of St Bartholomew's Hospital. He succeeded Roy as Professor of Pathology at Cambridge in 1897. But he did not hold the chair long, for he died in 1898 at the early age of 35 , being succeeded by Dr Sims Woodhead.

The Secretary reported letters of acceptance of the Honorary Membership from Professors Chauveau, Du Bois-Reymond and Sir Joseph Lister.

[The first Minute Book-which contains the history of the meetings of the Society for the sixteen years 1876 to 1892 -ends here. There are six others covering the remainder of the first fifty years of the Society's existence.] 
December 10th, 1892 (at Charing Cross Hospital Medical School). The dinner was held at Gatti's Restaurant with Professor McKendrick in the chair. Forty-four members and guests were present. A letter from Professor Herzen to Professor Foster was read inviting the Society to co-operate in a testimonial to Professor Maurice Schiff of Geneva on the occasion of his 70th birthday. It was decided to send a letter of congratulation to Professor Schiff on the part of the Society. The draft of this letter and Professor Schiff's reply are in the Minute Book.

It was proposed by Professor Schäfer that the draft rules prepared by the Revision Committee be printed and circulated before the next meeting. This was agreed to.

An invitation was received from Professor McKendrick to meet at Glasgow in the ensuing year.

January 21st, 1893. This, the Annual Meeting, was held in the Charing Cross Hotel-after a scientific meeting at the Conjoint Laboratories. Forty-six members and guests were present at the dinner, with Dr Sims Woodhead in the chair.

The Secretary's report showed an increase of members from 138 to 144 .

The Secretary also reported that the second International Congress had been held at Liége under the presidency of Professor Léon Fredericq: that twenty-six members of the Society had attended and nine had contributed communications or demonstrations. The report of the Treasurer showed a satisfactory balance.

The Committee and Officers of the Society having been chosen, the following new members were balloted for and elected, namely, H. K. Anderson, J. Fawcett, A. S. Grünbaum, A. H. Kanthack, M. S. Pembrey ${ }^{1}$.

Dr Fawcett is now Consulting Physician to Guy's Hospital.

Dr A. S. Grünbaum, who in 1914 changed his name to Leyton, was working at St Thomas's Hospital Medical School, afterwards accompanying Sherrington to Liverpool. In 1905 he was appointed to the chair of Pathology in Leeds University. He died in 1922.

The new rules, drawn up by a committee appointed for the purpose, came under consideration, and were passed, with certain amendments.

February 11th, 1893 (at University College). At the scientific meeting demonstrations were given by Bayliss, L. Hill, Russell and Waller. Professor W. Stirling occupied the chair at the dinner: thirty-nine members and guests were present.

1 The qualifications of candidates are now entered on the ballot-paper. 
The new rules again came up for discussion and additional amendments were introduced, the Chairman having ruled that the meeting was competent to do so. After this they were passed as a whole.

March 11th, 1893 (at King's College). Professor Halliburton was in the chair. Thirty-eight other members were present.

A discussion regarding the rules took place, some of the members calling in question the competence of the previous meeting to introduce amendments. Dr Sims Woodhead gave notice of a motion to rescind the amendments then introduced, exception being especially taken to the substitution of "one in three" for "one in five" as the rate for blackballing candidates.

This motion came up at the meeting of June 24th and was then agreed to.

May 21st, 1893 (at Cambridge). Mr Langley presided at the dinner which was held in St John's College. There was a large attendance (fifty-two). No business was transacted at the dinner but there were numerous communications at the afternoon meeting.

June 24th, 1893 (at Oxford). Professor Sanderson in the chair.

The following new members were balloted for and elected: H. Campbell (Guy's Hospital) ${ }^{1}$, W. Edmunds (Cambridge and St Thomas's Hospital), H. Morley Fletcher (Cambridge and St Bartholomew's), F. T. Oliver (Durham University), J. W. Pickering (St Bartholomew's Hospital).

W. Edmunds is Dr Walter Edmunds, well known as an authority on the thyroid.

Dr Herbert Morley Fletcher is now Senior Physician to St Bartholomew's Hospital.

F. T. Oliver is probably meant for Dr T. Oliver (now Sir Thomas Oliver), Professor of Medicine at Newcastle and formerly Professor of Physiology in the Newcastle-on-Tyne School of Medicine of Durham University.

Dr J. W. Pickering is a Lecturer at King's College, London.

July 8th, 1893 (at Guy's Hospital). The Society met here for the first time. Mr C. H. Golding-Bird occupied the chair. No business is recorded in the minutes of the dinner, but there were several communications at

1 This stands so in the minutes, but if Dr Harry Campbell is meant it should be "St Bartholomew's." 
the afternoon meeting, which were, as usual, published in the Journal of Physiology.

October 21st, 1893 (at University College). What is termed in the minutes an "extra" meeting was held to which Professor Kronecker of Bern and Professor Christian Bohr of Copenhagen were invited. Scientific communications were made by both guests and by some of the members.

The dinner meeting was held at the Horse-shoe Hotel, Tottenham Court Road, with Professor Sanderson in the chair and thirty-three other members and guests. The Chairman having expressed a warm welcome on behalf of the Society to the two distinguished foreign visitors, Professor Kronecker replied on behalf of both, and stated that he looked forward to return the welcome on the occasion of the meeting of the third International Physiological Congress at Bern in 1895.

Another guest was Professor R. Semon of Jena (brother of Sir Felix Semon), who was returning from pursuing researches in Zoology in the Tropics. His health having been proposed by Professor Yeo was duly honoured. After this Dr Pye-Smith proposed the health of Professor Yeo "who was, for this once, revisiting the scene of his former labours."

November 11th, 1893 (at St Mary's). The scientific meeting was held in Dr Waller's laboratory and the dinner meeting at a neighbouring restaurant.

Dr Foster proposed, Dr Sanderson seconded and Mr Horsley supported a vote of condolence on the death of Sir Andrew Clark, Bart., F.R.S. ${ }^{1}$.

Dr Foster called the attention of members to the International Medical Congress to be held in Rome at Easter 1894, and expressed the hope that there would be a large attendance of British physiologists.

December, 1893. The December meeting of 1893 (the day of the month is omitted in the minutes) was held at Charing Cross Medical School. Dr Mott was in the chair at the dinner and twenty-seven members were present.

A letter was read from Dr Foster announcing that Mr Langley had taken over the proprietorship of the Journal of Physiology, and another letter from Mr Langley suggesting a change in the financial relations of the Journal and the Society. A considerable discussion took place and finally it was resolved to refer both letters to the Committee for consideration and report.

1 The eminent physician and former President of the Royal College of Physicians of London. Sir Andrew Clark had always taken a firm stand in support of physiological experiments on animals. 
January 20th, 1894. This, the Annual Meeting, was held at the Charing Cross Hotel with Dr Sims Woodhead in the chair. There were present thirty-six members and one guest.

Certain alterations in the rules were agreed to.

The Committee and Officers having been chosen, the ballot for new members was next proceeded with. The following were elected: G. J. Burch (Oxford), Louis Cobbett (Cambridge), A. E. Garrod, Vaughan Harley, J. S. Menzies, W. H. R. Rivers, J. Risien Russell and W. H. Thompson.

Dr Louis Cobbett is a Lecturer on Pathology at Cambridge. He was for a time Professor of Pathology in the University of Sheffield.

Dr A. E. Garrod is now Sir Archibald Garrod, K.C.M.G., F.R.S., successor to Sir William Osler in the Regius Professorship of Medicine in the University of Oxford.

Dr Vaughan Harley, son of Dr George Harley, F.R.S. (p. 2), was Professor of Chemical Pathology in University College, London. He died in 1923.

Dr J. A. Menzies was Assistant to Professor Stirling at the Owens College, Manchester, and subsequently became Professor of Physiology in the Newcastle School of Medicine. He died in 1921.

Dr W. H. R. Rivers (F.R.S. 1908), a distinguished psychologist, was Lecturer on Psychology at Cambridge and Fellow of St John's College. He died in 1922.

Dr J. Risien Russell, who was working with Horsley on cerebral localisation, is a neurologist and physician in London.

Professor W. H. Thompson (later Sir W. H. Thompson, K.B.E.) was Professor of Physiology in Queen's University, Belfast, and afterwards filled the similar post in Trinity College, Dublin. He acted during the war as Adviser to the Ministry of Food. He was killed in the torpedoing of the "Leinster" in 1918, one of the last victims of the German submarine campaign.

The report on the letters from the editors of the Journal of Physiology was read. It suggested two alternatives, (1) the raising the subscription of members to $31 s$. $6 d$., of which $21 s$. was to be contributed to the Journal, and (2) that the association of the Journal with the Society be discontinued. The Committee recommended the former alternative, which was adopted by the meeting.

February 10th, 1894 (at King's College). At the dinner in the evening Professor Halliburton was in the chair: there was an attendance of 
forty members and guests, amongst the latter Professor Filehne and Dr George Oliver.

Professor Filehne was Professor of Pharmacology in Breslau. $\mathrm{He}$ died in 1927 at the age of 83.

Dr George Oliver was a physician practising in the summer at Harrogate. He wrote chiefly on the pulse and on the measurement of blood-pressure in man. He was working with the writer at University College this winter on the effects of suprarenal and other glandular extracts on the circulation. He joined the Society in June 1894. He died in 1915.

Some discussion took place regarding a proposal by the Association of the Advancement of Medicine by Research to publish a book on the subject of Animal Experimentation; but the matter was shelved for the time being.

Another proposition met with more favour, that namely, to give, conjointly with the Neurological Society, a dinner to the Croonian Lecturer, Professor Ramón y Cajal, similar to that given in 1892 to Professor Mosso on a like occasion ${ }^{1}$.

March 10th, 1894 (at University College). On the occasion of the dinner to Cajal the Society met at Frascati's Restaurant, Oxford Street, after a scientific meeting at University College. Professor Schäfer occupied the chair. The following members were also present: Allen, Bayliss, Beevor, Bokenham, Boyce, Bradford, Brodie, Brunton, Buckmaster, Copeman, Cunningham, Fawcett, Ferrier, Gaskell, Garrod, GoldingBird, Gotch, Green, Grünbaum, Haldane, Halliburton, Head, Harley, Hewlett, L. Hill, Horsley, Kanthack, Kent, Marcet, Mott, Page, Pembrey, Phillips, Plimmer, Ransom, Rivers, Ringer, Rolleston, Rüffer, Russell, Sherrington, Starling, W. Stirling, Symes, Tuke, Washbourn, Hale White.

The Chairman proposed the health of Professor Cajal in a short speech, in which he alluded to the important advances in our knowledge of the nervous system which were due to our guest. The latter expressed his thanks for the reception given him by the Society, but as the reply was in Spanish it was understood by very few members. "For mine own part, it was Greek to me."

1 The Mosso dinner was given in the evening of the same day he delivered his lecture (March 24th, 1892) at "Limmers"(?) restaurant, Professor Michael Foster in the chair. It appears not to have been considered a formal meeting of the Society, for there is no record of it in the Minute Book. 
June 23rd, 1894 (at Oxford). Dr J. S. Haldane was in the chair at the dinner. Nineteen members were present.

The only business was the election of new members, as follows: J. Mitchell Clarke (Bristol), A. J. Whiting (London), H. G. Plimmer (London), J. S. Macdonald, G. Oliver, Fred Smith, A. Eichholtz (Cambridge), D. G. Hamilton, B. Halford (Melbourne), J. W. Barrett (p. 85).

Mr H. G. Plimmer (F.R.S. 1910) was a distinguished pathologist in London. He was Bacteriologist to St Mary's Hospital and Pathologist to the Cancer Hospital. He died in 1918 just after a chair of Comparative Pathology had been made for him at the Imperial College of Science.

Dr J. S. Macdonald (F.R.S. 1917) is now Professor of Physiology in Liverpool. He previously occupied the chair of Physiology in Sheffield.

Fred Smith was Major F. Smith of the Army Veterinary Department. He is now Major-General Sir F. Smith, C.B., K.C.M.G. Professor D. G. Hamilton was Professor of Pathology in the University of Aberdeen. He died in 1909.

Dr A. Eichholtz is now Chief Medical Inspector of the Board of Education.

Dr B. Halford's name does not occur in any of the printed lists of members. He appears to have died shortly after his election.

July 14th, 1894 (at St Bartholomew's). Various communications were given in the laboratory in the afternoon. In the evening Dr Klein was in the chair. There were thirty-nine other members and guests present.

It was arranged to hold a special meeting at Oxford during the meeting of the British Association. This was the first meeting of the Association at which an independent Section of Physiology was constituted; the writer was the first president. The meeting of the Physiological Society at the same time and place materially contributed to its success.

August 11th, 1894 (at Oxford). This meeting was in the afternoon in the Physiological Laboratory, and in the evening at Magdalen College, Professor Burdon Sanderson in the chair. Forty-two members were present. The following were among the guests: Professor L. Hermann (Königsberg), Professor T. W. Engelmann (Berlin), Professor R. Dubois (Lyons), Professor W. Filehne (Breslau), Professor P. Heger (Brussels), Professor F. Fredericq (Liége), Professor J. Gaule (Zürich), Professor Th. Ziehen (Jena), Dr L. Bruns (Hanover), Dr E. Dupuy (Paris), Professor 
W. Osler (Baltimore). The Chairman proposed the health of the foreign guests. It was responded to by Hermann, Engelmann, Dubois, Heger, Fredericq and Gaule.

Other meetings of the Society in 1894 were held on October 27 th at Guy's Hospital with Dr Pavy in the chair, and on November 10th, at Dr Waller's private laboratory, with dinner at the Eyre Arms.

January 26th, 1895. The Annual Meeting for 1895 was held at Charing Cross Hotel. Dr Sanderson presided over an assembly of forty-six members and guests. After the ballot for Committee and Officers the following new members were elected: H. E. Durham (Cambridge), Eugène Dupuy (Paris), J. Lockhart Gibson (Brisbane), Gustav Mann (Oxford), William Ramsden (Oxford), A. B. Roxburgh, Thomas Stevenson.

Dr H. E. Durham was John Lucas Walker Student at Cambridge and Research Scholar in Pathology at Guy's Hospital.

Dr Eugène D upuy seems to have been the first foreign physiologist to be elected an ordinary member of the Society. It now includes several, since there is nothing in the rules specifying that members shall be of British nationality. Dr Dupuy, who was a frequent visitor to England, died in 1924.

Dr Gustav Mann was Dr Sanderson's Assistant for Histology in Oxford. He was subsequently appointed to the Professorship of Physiology in Tulane University, New Orleans: but resigned that chair shortly afterwards. He died in 1921.

Dr W. Ramsden is now Professor of Biochemistry in the University of Liverpool.

Dr Thomas Stevenson was Lecturer on Medical Jurisprudence at Guy's Hospital. He was subsequently knighted. He died in 1908.

Dr J. Lockhart Gibson is a distinguished Edinburgh graduate who at first worked at Physiology but afterwards went into practice as Ophthalmic Surgeon in Brisbane. During the war he acted as Ophthalmic Surgeon in the Australian army.

The Treasurer's report showed a credit balance of $£ 90.10 s .7 d$. The Secretary also read his report, which showed that nineteen members had been elected, two had resigned and one had died. Nine meetings had been held - a greater number than in any previous year.

It was moved, seconded and carried that "the fees paid from the funds of the Society for table service at the dinners be discontinued ${ }^{1}$."

1 But in spite of this and a previous resolution (p. 51) the practice has continued. 
Dr Ruffer communicated a letter from the Law Officers of the Crown signed "R. T. Reid" (Attorney General, afterwards Lord Chancellor) and "Frank Lockwood" (Solicitor General), in which the nature of experiments under the Vivisection Act is defined. The letter was ordered to be entered in the minutes.

The attention of members was drawn to the announcement that the third International Physiological Congress would be held at Bern in the first week of September, under the Presidency of Professor Kronecker.

No business was transacted at the dinner meeting of February 19th, 1895, held at King's College under the Presidency of Professor Halliburton, except that it was decided to call a special meeting in order to alter the rules so as to allow of the appointment of a second Secretary.

This special meeting was accordingly held on March 16th, at University College, with Professor Michael Foster in the chair, and the alterations made. The ordinary scientific meeting then followed, and was succeeded as usual by the dinner meeting. This was at Frascati's Restaurant with Professor Schäfer in the chair. Fifty-nine members and guests were present, the occasion being taken to offer a welcome to Professor T. W. Engelmann of Berlin, who was visiting this country to give the Croonian Lecture before the Royal Society. Professor Engelmann's health was proposed by the Chairman, seconded by Professor Foster. It was received with enthusiasm and suitably acknowledged. Amongst others present at the meeting three names occur which have not before been entered in the minutes, namely: D. Nabarro, A. D. Phear and Benjamin Moore.

Dr D. N. Nabarro was at the time working in the Physiological Laboratory at University College. He is now Pathologist to the Hospital for Sick Children, Great Ormond Street, London.

Dr A. D. Phear is Physician to the Royal Free Hospital. He was working with Sydney Ringer at University College.

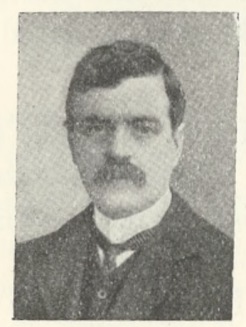

Dr Benjamin Moore(F.R.S. 1912) was Assistant to the Professor of Physiology at University College. He became successively Professor of Physiology at Yale University, Professor of Biochemistry at Liverpool, and Professor of Biochemistry at Oxford. He died in 1922.

May 18th, 1895 (at Cambridge). The dinner was at St John's College, with Dr Gaskell in the chair. There were fortyseven members and guests present. 
The Chairman alluded to the recent death of Carl Ludwig, one of the Honorary Members of the Society ${ }^{1}$.

It was announced that the date of the commencement of the International Congress at Bern had been altered to September 9th.

June 29th, 1895 (at Oxford). The dinner was at Magdalen College with Professor Gotch, who had lately succeeded. Burdon Sanderson in the Waynflete Professorship, in the chair. There were thirty-seven members and guests present. Amongst these was J. B. Leathes.

Dr Leathes (F.R.S. 1911) was then a Lecturer at St Thomas's Hospital Medical School and afterwards Professor of Pathological Chemistry at the University of Toronto. He is now Professor of Physiology in the University of Sheffield.

Occasion was taken at this meeting to present to Professor Sherrington (who, having been appointed to the Professorship of Physiology in the University of Liverpool, had resigned the Secretaryship), on behalf of the members of the Society, a gift of silver plate bearing a suitable inscription. The presentation also included a special gift to Mrs Sherrington. Speeches were made by the Chairman, by Professor Burdon Sanderson and by Dr Mott. The Secretary expressed warm appreciation on behalf of Mrs Sherrington and himself both of the gifts and of the speeches accompanying them.

A ballot for new members was then taken. The following were elected: P. C. Colls (King's College, London), G. Lovell Gulland (now Professor of Medicine in Edinburgh), R. M. Horne (Manchester), J. B. Leathes, Allan MacFadyen (College of State Medicine, London).

January 11th, 1896. This, the Annual Meeting, was held at the Charing Cross Hotel with Dr Pembrey in the chair. Sixteen other members were present.

The Committee having been elected and the Treasurer, Dr W. H. Gaskell, re-elected, two new Secretaries were chosen (in accordance with the rule adopted at a previous meeting), namely, Dr E. H. Starling and Dr L. E. Hill. Three new members were also elected, namely, F. W. Tunnicliffe (London), W. S. Lazarus-Barlow (Demonstrator of Pathology, Cambridge) and Robert H. Bolam (Demonstrator of Physiology, Newcastle).

1 I have been unable to find in the Minute Book any mention of Ludwig's election. Perhaps it was in the excised portion (p. 83).

$\mathrm{PH}$. 
Dr F. W. Tunnicliffe became Lecturer on Therapeutics and Physician to King's College Hospital.

Dr W. S. Lazarus-Barlow was Professor of Experimental Medicine at the Middlesex Hospital Medical School (now retired).

Sir Robert Bolam, O.B.E., is Physician in the Skin Department of Victoria Infirmary, Newcastle-on-Tyne, and a member of the General Medical Council.

The Secretary reported that nine meetings had been held during 1895, and that the number of members was now 171. Also that many members attended the Third International Physiological Congress at Bern, presided over by Professor Hugo Kronecker. The retiring Secretary "records his thanks to the members for the courtesy and cordial cooperation they have always given him."

The Treasurer's Report for 1895 shows a credit balance of 129.8 s. $2 d$.

February 15th, 1896 (at King's College). At the dinner, which, as usual, was preceded by a scientific meeting, Professor Halliburton occupied the chair. There were twenty-three other members present and six guests.

Dr Gaskell having asked to be relieved of his duties as Treasurer, it was resolved to request Dr Waller to act with him as Treasurer for the year.

Dr Starling moved and Professor Horsley seconded a motion affirming "that it is undesirable that any members of the Society should accept a teaching post in Physiology at any school where the authorities prohibit the laboratories from being licensed for experimental work." This was carried unanimously.

March 14th, 1896 (at King's College). Dinner at Frascati's Restaurant with Professor Schäfer in the chair. Thirteen members and two guests were present. One of the guests was Mr Benjamin Moore.

May 16th, 1896 (at Cambridge). Dinner at St John's College, with Professor Langley in the chair. Twenty-three members and five guests were also present. One of the guests was Dr W. E. Dixon.

June 27th, 1896 (at Oxford). The dinner was in Magdalen College Junior Common Room, with Professor Burdon Sanderson in the chair. Twenty-two members and nine guests were present. The guests included Professor James Ritchie and Professor W. R. Dunstan. Miss Florence Buchanan was present as a visitor at the Scientific Meeting. 
Professor Ritchie was at that time Professor of Pathology in Oxford: he afterwards became Director of the College of Physicians' Laboratory in Edinburgh; and Professor of Bacteriology in Edinburgh University (1913). He died in 1923.

Miss Florence Buchanan was acting as assistant to Burdon Sanderson, and worked with him, and independently, at electrophysiology, especially of muscle.

Mr W. R. Dunstan was Professor of Chemistry to the Pharmaceutical Society; and afterwards Director of the Imperial Institute. He is now Sir Wyndham Dunstan, F.R.S.

The following new members were elected: W. Langdon Brown (Cam bridge), P. Horton Smith (London), Benjamin Moore, H. Willoughby Lyle (King's College), I. L. Tuckett (Cambridge), S. W. F. Richardson (St Thomas's), A. Edmunds (King's College).

Dr W. Langdon Brown is now Physician to St Bartholomew's Hospital.

Dr Horton Smith is now Sir Percival Horton-Smith Hartley, Physician to St Bartholomew's Hospital and to the Brompton Hospital for Consumption.

Mr Willoughby Lyle is now Ophthalmic Surgeon to King's College Hospital.

Dr Ivor Lloyd Tuckett was Demonstrator of Physiology in Cambridge and Fellow of Trinity College.

Mr S. F. W. Richardson was working on "Heat Contraction of Muscle" with Brodie. He is now in Cape Town.

Mr Arthur Edmunds is now Surgeon to King's College Hospital.

October 17th, 1896 (at St Bartholomew's). Dinner was at the Holborn Viaduct Hotel. Dr Klein was in the chair: thirteen other members and six guests (names not entered) were present. The Secretary, Dr Starling, read the draft of a letter congratulating Professor Kühne on the 25th anniversary of his installation as Professor of Physiology in the University of Heidelberg. The letter and reply are in the Minute Book.

This was the first meeting held at St Bartholomew's.

November $14 t h, 1896$. This meeting was held for scientific communications in Dr Waller's laboratory at his private house (16, Grove End Road), and for dinner at the Eyre Arms Hotel close by. Dr Waller was in the chair. Sixteen members and two guests, Messrs Bullock and Squire, were present. 
Bullock is doubtless meant for Dr William Bulloch (F.R.S. 1913), now Professor of Bacteriology in the London Hospital Medical College.

Squire is probably Dr J. E. Squire, who was Physician to the Brompton Hospital for Consumption.

The Secretaries were directed to give the members at least fourteen days' notice of each meeting, and notice of communications at least ten days beforehand. It was decided to hold the next meeting at the London Hospital Medical College.

December 12th, 1896 (at the London Hospital). This meeting was accordingly held for scientific communications in the Physiology Department, and for dinner in the Students' Club. Dr Leonard Hill took the chair, and eleven members were present as well as three guests (H. Barnard, G. Elliot-Smith and Munro Scott).

Mr H. L. Barnard, F.R.C.S., was working with Leonard Hill at the method of determining blood-pressure in man. He was Assistant Surgeon at the London Hospital. He died in 1908.

Dr G. Elliot Smith (F.R.S. 1907) was successively Professor of Anatomy in Cairo and in Manchester. $\mathrm{He}$ is now Professor of Anatomy in University College, London, where he succeeded Sir George Thane.

Dr Munro Scott was at the time Warden of the London Hospital Medical School.

This was the first time the Society held a meeting at the London Hospital.

January 16th, 1897 (at Charing Cross). This, the Annual Meeting, was held at the Charing Cross Hotel, after a scientific reunion at the Charing Cross Hospital Medical School. Dr Pembrey took the chair: twenty-nine other members and five guests were present (unnamed).

Reports for the year were presented by the Secretaries and Treasurer. The Secretaries reported the death of Professor E. Du Bois-Reymond, one of the Honorary Members, and the further loss of three members by death, namely, R. Horne (Manchester), H. Newell Martin, and Sir Benjamin Richardson, F.R.S., and of four by resignation, namely, Charles Roy (on account of illness), E. B. Poulton, Mansell-Moullin and A. de Watteville.

A vote of condolence with the widow of Professor Du Bois-Reymond 
was moved by Dr Waller, seconded by Dr Gaskell and adopted; as was a vote of thanks to Dr Gaskell for his long labours on behalf of the Society as Treasurer ${ }^{1}$. This was moved by Professor Schäfer and seconded by Professor Gotch and carried by acclamation.

After election of the Committee and the re-election of the Officers the ballot for new members took place. The following were declared elected: A. E. Russell (St Thomas's Hospital), W. R. Dunstan, H. M. Vernon (Oxford), Swale Vincent, A. B. Macallum (Toronto), W. H. Wilson (Oxford), D. N. Nabarro, W. Stafford (Nottingham), Harold Barnard.

Dr A. E. Russell is now Physician to St Thomas's Hospital.

Dr H. M. Vernon was Demonstrator of Physiology at Oxford, but is now engaged in work on Industrial Fatigue.

Dr Swale Vincent was at University College, London, at this time, and afterwards worked in Edinburgh. He subsequently became Professor of Physiology in the University of Manitoba, Winnipeg. He is now Professor of Physiology at the Middlesex Hospital Medical School.

Dr A. B. Macallum (F.R.S. 1906) was Professor of Physiology and subsequently of Biochemistry in the University of Toronto. $\mathrm{He}$ is now Professor of Biochemistry in McGill University, Montreal.

Dr W. H. Wilson is now Professor of Physiology at Cairo.

A new feature was introduced at this, the twenty-second Annual Meeting, namely the fixing of the dates and places of meeting for the ensuing twelve months. Nine meetings were arranged for.

March 20th, 1897 (at University College). After a scientific meeting in the Laboratory the dinner meeting was held in Frascati's Restaurant with Professor Schäfer in the chair. Sixteen other members and two guests (W. Rockwood and H. Hawker) were also present.

Both the guests were working in the Physiological Laboratory of University College, Dr Rockwood with Benjamin Moore on absorption of fats from the intestine. He afterwards became Lecturer on Physiology in the Medical College of Colombo. Mr H. Hawker afterwards went to Sydney as Assistant to the Professor of Physiology.

1 The minute adds "a post which he held since the foundation of the Society." I think this must have been added by the Secretary in writing up the minutes, since I was well aware that during the first eight years of the Society Mr George J. Romanes acted as Treasurer. 
May 8th, 1897 (at Cambridge). After the scientific meeting at the Physiological Laboratory, the dinner was held in St John's College, Professor Foster in the chair, with thirty-five other members and fourteen guests.

Two delegates (W. D. Halliburton and E. H. Starling) were designated to represent the Society on the Catalogue Committee of the Royal Society. The Society agreed to co-operate in this work, but expressed inability to afford financial assistance ${ }^{1}$. Fourteen of the members present at the meeting offered to aid in the work of cataloguing.

June 12th, 1897 (at Guy's Hospital). This meeting was held in the new laboratories at Guy's Hospital: several scientific communications were made. The dinner was in the College-with Dr Pye-Smith in the chair; fifteen members and five guests (names not recorded) were present.

The following new members were elected: R. Hutchinson (London Hospital), F. Eve (Cambridge), John Macfadyean.

R. Hutchinson should be Dr Robert Hutchison, Physician to the London Hospital and to the Hospital for Sick Children, Great Ormond Street.

F. Eve is Dr F. C. Eve, now Senior Physician to the Royal Infirmary, Hull.

Sir John Macfadyean is Professor of Comparative Pathology and Principal of the Royal Veterinary College.

On the motion of Professor Schäfer, seconded by Professor Horsley, the Committee was empowered to spend a sum not exceeding ten guineas in obtaining Counsel's opinion on a recent anti-vivisectionist libel on two of its members, W. M. Bayliss and L. E. Hill.

July $3 r d, 1897$ (at Oxford). The meeting for scientific communications was held in the Physiological Laboratory and for dinner in Magdalen College ${ }^{2}$.

The Chairman, Professor Gotch, presented Dr Gaskell on behalf of the Society with a set of silver candlesticks and a tea caddy, in recognition of the services he had rendered the Society during his long tenure of the office of Honorary Treasurer.

1 But eventually the Society voted $£ 10$ a year towards the expenses of cataloguing papers dealing with Physiology.

2 The members present at this meeting are not recorded in the minutes. Later this omission became frequent. 
October 16th, 1897 (at St Bartholomew's). The Society met for scientific communications in the Physiological Laboratory of the Medical School, and for dinner at the College. Dr Klein occupied the chair. The attendance was comparatively small (nine members and two guests), and no business is recorded except that the Secretaries were instructed to offer condolences on behalf of the Society to the relatives of the late Professor R. Heidenhain (of Breslau), and Professor Drechsel (of Bern) ${ }^{1}$.

November 13th, 1897. The Society met in Dr Waller's private laboratory at 16, Grove End Road, for scientific business and at the Eyre Arms for dinner. Dr Waller was in the chair. There were, besides, twenty-three members ${ }^{2}$ and three guests (the guests are not named).

A resolution was proposed by Dr Starling and seconded by Professor Schäfer deprecating the introduction of Biology into the ordinary medical curriculum as tending to occupy time which should be devoted to Physiology. The motion was rejected by nine votes to six.

December 11th, 1897 (at St Thomas's). This meeting was held in the Physiological Laboratory of St Thomas's Hospital-the first meeting to be held there. At the dinner Dr Brodie took the chair. Nineteen members were present and five guests (not named).

A discussion took place regarding the new proposals of the General Medical Council regarding the preliminary sciences and the medical curriculum. A resolution affirming that, whilst it is desirable that Biology shall be retained, it is necessary that adequate time (at least two winter sessions and one summer session) should be given to Physiology, was ultimately adopted and ordered to be transmitted to the General Medical Council and the Royal Colleges.

On the motion of Dr Starling it was resolved that a notice be sent round to members of the Society inviting them to subscribe to the Drechsel Memorial Fund, regarding which a letter from Professor Kronecker was laid before the Society ${ }^{3}$. This was agreed to.

January 15th, 1898 (at Charing Cross). The Annual General Meeting for 1898 was held in the Charing Cross Hotel (preceded by a scientific meeting at the Charing Cross Hospital Medical School). Professor Michael Foster took the chair at the dinner and there were present in addition thirty-five members and five guests (not named).

1 The letters of acknowledgment are preserved in the minutes.

2 The members present included Professor Anderson Stuart of Sydney.

3 The letter is preserved in the minutes. 
It may be of interest to give the names of the members present as an indication of those who were in the habit of attending the annual meetings at this period. The list as entered in the minutes is: "L. Hill, L. Shore, Wright, Waller, Page, Buckmaster, Barnard, Grünbaum, Sherrington, Vincent, Moore, Bayliss, Edmunds, Gotch, Schäfer, Sanderson, Hopkins, Ramsden, Lorraine-Smith, L. Barlow, Philipps, Pembrey, Halliburton, Harley, Anderson, Garrod, Edkins, Gaskell, Fletcher, Plimmer, Starling, Head, Beevor, Mann, Russell."

For the same reason the names of the Committee and Officers elected are given. They are: "Allen, Bayliss, Brodie, Edkins, Foster, Gaskell, Gotch, Halliburton, Langley, MacMunn, Pembrey, Reid, Sanderson, Schäfer, Sherrington"-with A. D. Waller as Treasurer, and E. H. Starling and Leonard Hill as Secretaries.

The Committee and Officers having been chosen, the following new members were balloted for and declared elected: W. C. Pakes (Johannesburg), C. F. Myers-Ward (Sheffield), J. le M. Bunch (University College), W. M. Fletcher (Cambridge), F. W. Andrewes (St Bartholomew's), W. Bulloch and O. F. F. Grünbaum (London).

Dr W. M. Fletcher is now Sir Walter Morley Fletcher, K.B.E., F.R.S., Secretary of the Medical Research Council.

Dr Myers-Ward afterwards became Lecturer on Physiology in the Medical School of Charing Cross Hospital. He died in 1914.

Dr F. W. Andrewes is now Sir Frederick Andrewes, O.B.E., Professor of Pathology at St Bartholomew's.

Dr O. F. F. Grünbaum (who, in 1914, changed his name to Leyton) is Physician and Lecturer on Pharmacology at the London Hospital.

The dates and places of meeting were arranged for the ensuing twelve months.

A joint letter from Professor Rutherford and Dr Noël Paton was read inviting the Society to meet in Edinburgh at the end of July during the meeting of the British Medical Association. The invitation was referred to the Committee for consideration.

One of the Secretaries, Dr Leonard Hill, was appointed editor of the Proceedings for the ensuing year.

Professor Sherrington moved and Professor Halliburton seconded a resolution that a British Organising Committee be formed for the purpose 
of arranging the business of the forthcoming Physiological Congress at Cambridge, to consist of the Committee of the Physiological Society with the addition of Drs Pye-Smith and Noël Paton, Professors Rutherford, McKendrick, Haycraft, Stirling, Purser and W. H. Thompson. This was agreed to, and it was also agreed to guarantee $£ 100$ towards the expenses of the Congress.

It was resolved that, as a rule, communications to the Society should be limited to twenty minutes. An attempt was also made to oust the dinner from the predominant position it had hitherto occupied, some of the members wishing to restrict the dinner to four meetings in the year: others desired that every meeting in London should be accompanied by a dinner, as had hitherto been the custom. Eventually the question was referred to the Committee for consideration and report. [At a subsequent meeting it was agreed to alter the rules so as to make a dinner compulsory at only six meetings a year instead of at every meeting.]

February 12th, 1898 (at King's College). At the dinner, with Professor Halliburton in the chair, ten other members and three guests were present.

On the recommendation of the Committee "the invitation of Professor Rutherford and Dr Noël Paton to hold a meeting of the Society in Edinburgh in the following July was refused, with regrets."

March 12th, 1898 (at University College). This was a special meeting for making the proposed changes in the rules - so that it was now enacted that the ordinary meetings of the Society are to be held in the afternoon for the purpose of making demonstrations and communications (demonstrations to have the preference) and that communications are to be limited to twenty minutes except by express vote of the meeting. Further that at six meetings (which were specified) "the members shall dine together at 6.30 o'clock: the minutes to be read only at these meetings."

Professor Kühne of Heidelberg, Professor Engelmann of Berlin and Professor Marey of Paris were elected Honorary Members.

May 7th, 1898 (at Cambridge). The dinner was held in Trinity College, Professor Langley in the chair. Thirty members and six guests were present. Amongst the guests we find the name of Professor Bottazzi of Naples.

It was agreed to subscribe twenty-five guineas to the Drechsel Me- 
morial Fund (p. 119) and $£ 20$ towards the expenses of the International Catalogue Committee.

June 11th, 1898 (at Guy's Hospital). Professor Schäfer in the chair. Eight other members and two guests were present.

The following new members were elected: Professor A. White (Dublin), Dr W. Page May and Mr "Hubert" " Hawker.

Dr Page May was a distinguished neurologist, who died at a comparatively early age in 1910 . He worked chiefly on the conducting paths of the brain and cord.

July 9th, 1898 (at Oxford). The dinner was held at Magdalen College, Professor Gotch in the chair. Twenty-five other members and six guests were present.

The Secretary announced that, including the Society's donation, about $£ 75$ had been contributed from England towards the Memorial Fund to Professor Drechsel. Altogether 14,000 francs had been received by the Bern Committee: this would be wholly devoted to the support of the widow and children, the University of Bern having undertaken to erect a memorial over the grave at Naples.

November 12th, 1898 (at St Mary's). The dinner was held at a neighbouring restaurant, with Dr Waller in the chair. Eleven other members and three guests were present.

One of the guests was Dr A. P. Beddard, of Trinity College, Cambridge, and Guy's Hospital Medical School, where he was at the time Demonstrator of Physiology. He is now Senior Physician to Guy's Hospital.

From this time there is a change in the compilation of the minutes, the lists of names and even the number of members attending being only occasionally entered during the years 1899-1906, while from 1907 onwards the names of members and guests are omitted altogether: exception being made for distinguished foreigners. This change, while rendering an account of the history of those years more easy to compile, detracts from its interest, since it leaves for record only the names of new members, and occasional matters of importance with which the Society has from time to time been concerned.

The list of new members elected during 1899 includes the names of F. E. Batten, A. P. Beddard, J. B. Farmer, F. S. Locke (King's

1 Should be "Henry." 
College), A Croft Hill, F. W. Goodbody, T. J. Horder, W. E. Dixon, S. C. Mahalanobis, Graham Brown, J. O. W. Barratt, R. Marshall.

Dr F. E. Batten was Physician to the National Hospital for the Paralysed and Epileptic.

Mr J. B. F armer (F.R.S. 1900) is now Sir John Bretland Farmer, Professor of Botany in the Imperial College of Sciences and Technology, London.

Dr F. S. Locke (working at King's College) is the inventor of the well-known Locke's solution-a modification of Ringer's fluid -and of many ingenious devices used in physiology.

Dr A. Croft Hill was working at Cambridge on the reversibility of the action of enzymes. He is now practising in London.

Dr F. W. Goodbody was Assistant Professor of Pathological Chemistry in University College, London.

Dr T. J. Horder is now Sir Thomas Horder, Bart., Physican to St Bartholomew's Hospital.

Dr W. E. Dix on (F.R.S. 1911) was Professor of Materia Medica in King's College, London. He is now Reader in Pharmacology in the University of Cambridge.

Dr S. C. Mahalanobis is Professor of Physiology in the University of Calcutta.

Dr J. Graham Brown was an eminent Edinburgh physician, who devised a number of ingenious physiological apparatus. He is best remembered for his work with Roy on the capillary circulation. He died in 1925.

Dr J. O. W. Barratt afterwards became Director of the Cancer Research Laboratory in the University of Liverpool.

R. Marshall is Dr C. R. Marshall, now Professor of Materia Medica in the University of Aberdeen, but at that time in Dundee.

The death was reported during 1899 of two distinguished members of the Society, namely, Sir W. Roberts, F.R.S., and Professor Rutherford, F.R.S., one of the original members. The resignation, amongst others, of Mr A. G. Dew-Smith, another of the original members (p. 26), was also reported.

The new members elected in 1900 include the names A. W. Sikes, E. I. Spriggs, A. B. Boycott, R. W. Dodgson, T. H. Milroy, R. Row, W. A. Osborne, Karl Grube, J. W. H. Eyre, A. W. Cadman, H. C. 
Haslam, H. H. Dale, W. J. Smith-Jerome, J. Barcroft, J. J. R. Macleod and G. H. F. Nuttall.

A. B. Boycott is a mistake for Dr A. E. Boycott (F.R.S. 1914), now Professor of Pathology in University College Medical School.

Dr T. H. Milroy is Professor of Physiology in Belfast. He was at this time Assistant in the Department of Physiology in Edinburgh.

Dr R. Row, O.B.E., was working at this time in the University College laboratory. $\mathrm{He}$ is now Physician to the Parsi General Hospital, Bombay.

Dr J. W. H. Eyre is Professor of Bacteriology at Guy's Hospital.

Dr H. H. Dale, C.B.E.(F.R.S. 1914), is Director of the Biochemical Laboratory of the Medical Research Council, and was formerly Director of the Wellcome Pharmacological Laboratory. He is at present one of the Secretaries of the Royal Society.

Dr W. A. Osborne was at that time working at University College. He is now Professor of Physiology in Melbourne.

Mr J. Barcroft, C.B.E. (F.R.S. 1910), is now Professor of Physiology in Cambridge, in succession to Langley. He acted as Hon. Secretary of the Society from 1909 to 1920.

Dr J. J. R. Macleod (F.R.S. 1923) is Professor of Physiology in Toronto. He received a Nobel Prize for Medicine in 1923.

Dr G. H. F. Nuttall (F.R.S. 1904) is Professor of Biology in Cambridge.

The death of Professor W. Kühne of Heidelberg, one of the Honorary Members, was reported to the Society at the meeting in June 1900. The Society also lost in the same year by death one of its most esteemed ordinary members, W. Marcet, F.R.S.

New members elected in 1901 include the names J. A. Milroy (Edinburgh), W. Hunter, D. J. Coffey (Dublin), F. A. Bainbridge (London), S. G. Hedin, N. H. Alcock (London), G. Bullot, S. Rowland (p. 156), G. Dean and I. Walker Hall.

Dr J. A. Milroy is now Professor of Biochemistry in Belfast.

Dr D. J. Coffey is now Pro-Vice-Chancellor of the National University of Ireland and President of University College, Dublin.

Dr F. A. Bainbridge (F.R.S. 1919) was Professor of Physiology at Newcastle, and afterwards Professor of Physiology at St Bartholomew's Hospital Medical School. He died in 1921. 
S. G. Hedin is now Professor of Physiological Chemistry in the University of Upsala.

Dr N. H. Alc o ck succeeded Dr Waller as Lecturer on Physiology in St Mary's Hospital Medical School. He was appointed to the chair of Physiology in McGill University, Montreal, in 1911. He died in 1913.

Dr G. Dean was Chief Bacteriologist in the Lister Institute.

Dr I. Walker Hall is Professor of Pathology at Bristol.

July 20th, 1901 (at Edinburgh). The Society for the first time held a regular meeting in the Physiology Department of Edinburgh University, Professor Schäfer, who had succeeded Professor Rutherford there in 1899, having invited the Society to meet in his Laboratory. Henceforth this became one of the recognised meeting places of the Society, although the distance from London rendered it impracticable to meet there oftener than every second or third year. This occasion was chosen for the inauguration of the new laboratory for Experimental Physiology, which had been erected as a memorial to Professor Hughes Bennett (the predecessor of Professor Rutherford in the chair of Physiology) by his daughter, Mrs Cox. It was opened by Sir John Burdon Sanderson, himself an old pupil of Hughes Bennett. The dinner was attended by the following members and guests, fifty-eight in all: Professor Schäfer (in the chair), Sir John Burdon Sanderson, Sir William Turner, Professor T. Fraser, Professor McWilliam, Professor Waymouth Reid, Professor R. Stockman, Professor Rubert Boyce, Professor Sherrington, Professor Hamilton, Professor Ewart, Dr Mott, Mr W. M. Bayliss, Dr B. Moore, Dr J. O. W. Barratt, Dr Waller, Dr C. D. F. Phillips, Dr J. Graham Brown, Dr Thomas Oliver, Dr A. S. Grünbaum, Dr Chalmers Watson, Dr Milne Murray, Dr Myers Ward, Dr Harvey Littlejohn, Dr T. H. Milroy, Dr J. A. Milroy, Dr P. T. Herring, Dr Sutherland Simpson, Dr Gulland, Dr Rivers, Dr N. H. Alcock, Dr Noël Paton, Mr Harold Stiles, Mr R. A. Bolam, Dr F. W. Pavy, Dr J. C. Dunlop, Dr Ker, Dr Allan McFadyean, Dr G. Mackay, Dr J. J. R. Macleod, Dr R. J. A. Berry, Sir J. Batty Tuke, Dr Berry Hart, Mr Alexis Thomson, Dr Page May, Dr R. Hutchison, Professor Th. Cash, Professor R. Muir, Dr Welsh, Dr A. L. Gillespie, Dr Logan Turner, Dr John Thomson, Dr J. Lorrain Smith, Dr C. F. White, Dr A. Bruce, Dr G. Gibson, Dr E. H. Fraser, Dr George Berry.

January 18th, 1902 (at King's College). This was the Annual Meeting. Dinner was at the Charing Cross Hotel, with Professor Halliburton in the chair. 
The Secretaries reported that the Society now numbers 211 ordinary and four Honorary Members. Eight meetings were held during the year, including one in Edinburgh, "where the Society received a most hospitable welcome."

The Treasurer reported a credit balance of $£ 177.10 s .9 d$.

A number of alterations were made in the rules-chiefly dealing with the conduct of meetings and the increase in amount of subscription.

The election of the Committee and Officers then took place: this was followed by the election of new members.

The following new members were chosen: D. F. Harris, Macdougall, P. T. Herring, E. H. Fraser, S. Simpson, R. Muir, C. S. Seligman (London).

Dr D. F. Harris is Professor D. Fraser Harris, formerly Professor in Dalhousie University, Halifax. This seems to have been a reelection.

Macdougall is Professor William Macdougall (F.R.S. 1912), formerly in Oxford, now at Harvard.

Dr P. T. Herring was at that time Assistant to the Professor of Physiology in Edinburgh. He is now Professor of Physiology in St Andrews University.

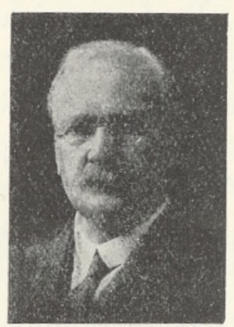

Dr Sutherland Simpson was at that time Assistant to the Professor of Physiology in Edinburgh. In 1908 he was appointed to the chair of Physiology in Cornell University. He died in 1926. An account of his life and work is given in the Quarterly Journal of Experimental Physiology, vol. xvIII.

Dr Robert Muir (F.R.S. 1911) is Professor of Pathology in the University of Glasgow.

July 5th, 1902 (at Oxford). Dinner at Magdalen College, Professor Gotch in the chair.

The following new members were elected: E. W. A. Walker, N. F. Surveyor (Bombay), V. J. Woolley (Cambridge), John Malcolm, C. S. Myers and J. H. Widdicombe (Cambridge).

Dr E. W. Ainley Walker is a Fellow of University College, Oxford, and Lecturer on Pathology. He was formerly Gordon Lecturer in Pathology to Guy's Hospital.

Dr V. J. Woolley is Lecturer on Pharmacology in St Thomas's Hospital Medical School. 
Dr John Malcolm was Assistant in the Department of Physiology, Edinburgh. He is now Professor of Physiology in Dunedin.

Dr C. S. Myers (F.R.S. 1915) is Director of the National Institute of Industrial Psychology and Reader in Experimental Psychology at Cambridge.

"An invitation from the Principal of the University of London for the Society to meet in the Laboratory of that Institution having been read it was resolved, on the motion of Dr Waller, seconded by Sir John Burdon Sanderson, that the invitation should be accepted."

January 17th, 1903 (at King's College). This was the Annual Meeting. Dinner was at the Charing Cross Hotel, with Professor Halliburton in the chair. The number of members attending is not given.

Dr Leonard Hill resigned the Secretaryship - after six years' tenureand Dr T. G. Brodie was selected to act along with Mr W. M. Bayliss, who had been appointed in January 1900. The Committee was also elected.

Five Honorary Members were elected, namely, Professor Ehrlich of Frankfurt; Professor L. Hermann of Königsberg; Professor Pflüger of Bonn; Professor Schmiedeberg of Strasburg; and Professor E. Hering of Leipzig.

The following new members were admitted: R. S. Woodworth (New York), S. W. Cole (Cambridge) and W. G. Smith (London).

Dr R. S. Woodworth is Lecturer on Psychology in Columbia University.

Mr S. W. Cole is Lecturer on Medical Chemistry at Cambridge.

Mr W. G. Smith became Lecturer on Psychology in Liverpool and afterwards in Edinburgh. He died in 1919.

The Treasurer's Report was read. The Report of the Secretaries was postponed until the March meeting.

Since January 1900 the minutes have been in Dr Leonard Hill's handwriting, but this now gives place to Mr Bayliss's. In every case the change of Secretary has produced some difference in the manner of keeping the minutes. Under the last two administrations it had been customary to omit the names of members and guests attending the dinner meetings, but Mr Bayliss reverts for a time to the old plan of recording the names.

March 21st, 1903 (at University College). Professor Starling in the chair. There were twenty-nine members and five guests present. Amongst 
the guests are the names of Scharlieb, Schryver, Henderson, Loewi and Priestley.

Scharlieb is Col. H. J. Scharlieb, M.D., C.M.G. (who in 1914 changed his name to Shirley), now chief Anæsthetist to University College Hospital.

Dr S. B. Schryver is Professor of Biochemistry in the Imperial College of Science, South Kensington.

Dr Loewi is now Professor of Pharmacology in Graz.

A vote of thanks was proposed to the retiring Secretary, Dr Leonard Hill, expressing appreciation of the services he had rendered the Society during his period of office.

May 16th, 1903 (at Cambridge). Dinner was at St John's College, with Professor Langley in the chair; there were present thirty-eight other members and eleven guests. Amongst the latter we find the names J. Gaskell, Elliott, Seward, Lucas, Mellanby and Henderson (E. E.).

Dr John Foster Gaskell is the son of Walter Gaskell, one of the original members and some time Treasurer. Dr J. Gaskell is now Assistant Physician to Addenbrooke's Hospital, Cambridge.

Elliott is Dr T. R. Elliott (p. 131).

Seward is Professor A. C. Seward, F.R.S., Master of Downing College, and Professor of Botany in the University of Cambridge.

Lucas is Keith Lucas (p. 131).

Mellanby. It is not clear whether this is Professor E. Mellanby (p. 142) or Professor J. Mellanby (p. 138), probably the former.

June 27th, 1903 (at Oxford). Dinner was at Magdalen College with Professor Gotch in the chair. There were present twenty-one members and seven guests. Amongst the latter are the names Dreyer and Aders Plimmer.

The following new members were elected to the Society, namely, Powell White (Manchester), Schryver, Loewi and Drysdale (London).

Dr Georges Dreyer, C.B.E. (F.R.S. 1921) is now Professor of Pathology in the University of Oxford.

Dr Powell White is a Lecturer on Pathology in the Victoria University, Manchester.

Dr Drysdale was Physician and Joint Lecturer on Medicine in St Bartholomew's Hospital (now Consulting Physician). 
July 25th, 1903 (at Edinburgh). The dinner was held in the North British Station Hotel, with Professor Schäfer in the chair. There were present fifteen members and eight guests. The guests included Harvey Littlejohn (now Professor of Forensic Medicine in Edinburgh), John Tait, T. H. Bryce (Professor of Anatomy in Glasgow), Andrew Hunter, W. Cramer and Major Elliot, I.M.S. (p. 131).

Professor Littlejohn died in August, 1927.

Dr W. Cramer was Lecturer on Biochemistry in Edinburgh. $\mathrm{He}$ is now at the Cancer Research Institute, London.

November 14th, 1903 (at Guy's Hospital). Dr Stevenson was in the chair: there were present twenty-three members and five guests.

The guests included Professor Atwater, the inventor of the large calorimeter chamber, which in an improved form has been employed with marked success by Professor F. G. Benedict at the Carnegie Nutrition Laboratory in Boston.

January 23rd, 1904 (at University College). At this, the Annual Meeting, thirty-three members and four guests were present, Professor Starling in the chair.

The Treasurer's report showed a credit balance of £297. $4 s .9 d$. as against last year's balance of $£ 150.9 s .8 d$. It was decided to invest the balance in the purchase of Consols.

The Secretary reported that the number of members was 216, the same as last year, seven new members having been elected and seven old members resigned.

The list of new members elected includes the names of W. Bain, E. E. Henderson, H. G. Chapman, H. R. Dean, R. H. Aders Plimmer, Andrew Hunter, Thomas Lewis, O. May (London), E. P. Cathcart.

Dr H. G. Chapman is now Professor of Physiology in Sydney.

Dr H. R. Dean is now Professor of Pathology at Cambridge.

Dr R. H.Aders Plimm er is Professor of Chemistry at St Thomas's Hospital Medical School. He is the son of Dr H. G. Plimmer (p. 110).

Dr Andrew Hunter was working in the Physiology Department of the University of Edinburgh. He afterwards went to Cornell as Associate Professor of Biochemistry, and is now Professor of Biochemistry in the University of Toronto.

Dr Thomas Lewis, now Sir Tho mas Lew is, K.B.E. (F.R.S. 1918), is Lecturer on Cardiac Pathology in University College Medical School, and Physician to the Hospital. 
Dr Otto May is a Cambridge graduate who worked on the nervous system, partly with Horsley. He is now a physician in London.

Dr E. P. Cathcart, C.B.E. (F.R.S. 1920), is Professor of Chemical Physiology in the University of Glasgow.

On the motion of Professor Sherrington, seconded by Sir Victor Horsley, it was decided to appoint a standing committee to report from time to time on Physiology in regard to Educational Questions. The following were nominated on the committee: Starling, Gotch, Waller, Halliburton, Edkins, Schäfer, Myers, Brodie and Sherrington.

March 19ih, 1904 (at King's College). Dinner at the Hotel Cecil with Professor Halliburton in the chair: there were present also eighteen members and four guests, amongst the latter Dr Simon Flexner, the Director of the Rockefeller Institute, New York.

May 21st, 1904 (at Cambridge). Dinner at Trinity College with Professor Langley in the chair: there were also present thirty-three other members and ten guests. Amongst the latter are the names Elliott, Laidlaw, Fröhlich and Hill.

Elliott is probably T. R. Elliott (p. 131).

Laidlaw is Dr P. P. Laidlaw (F.R.S. 1927), a member of the staff in Bacteriology at the Medical Research Council's Laboratories at Hampstead.

The death of Professor Marey, one of the Honorary Members, was reported. A vote of condolence with his relatives was moved by Sir John Burdon Sanderson and seconded by Professor W. Stirling and carried.

July 29th, 1904 (at Oxford). Dinner at Magdalen with Sir John Burdon Sanderson in the chair. There were present twenty members and twelve guests.

Amongst the guests were Professor Johansson of Stockholm, Professor Wesley Mills of Montreal, Dr Dakin, Professor Weldon, F.R.S., and Dr H. S. Raper.

Professor W. F. R. W eld on was Linacre Professor of Comparative Anatomy in Oxford; previously at University College, London. He died in 1906.

The following new members were elected: Major R. H. Elliot, I.M.S., W. V. Shaw (Oxford), J. G. Priestley (Oxford), James Ritchie, D. P. 
Rockwood, R. N. Salaman, B. J. Collingwood, A. Harden, T. R. Elliott, O. Rosenheim, Keith Lucas.

Dr W. V. Shaw, O.B.E., was Lecturer in Physiology in St John's College. He is now attached to the Ministry of Health.

Dr J. G. Priestley is Lecturer in Clinical Physiology in the University of Oxford.

Major Elliot, formerly Professor of Ophthalmology in Madras Medical College, is now Lecturer on Ophthalmology in the London School of Tropical Medicine. He was at the time home on leave from India, working at snake poison in the Departments of Physiology and Pharmacology of Edinburgh University.

Dr R. N. Salaman was Director of the Pathological Institute of the London Hospital.

Mr B. J. Colling w o od is now Professor of Physiology in St Mary's Hospital Medical School.

Dr A. Harden (F.R.S. 1909) is now Professor of Biochemistry at the Lister Institute.

Dr T. R. Elliott, C.B.E., D.S.O. (F.R.S. 1913) is now Professor of Medicine at and Physician to University College Hospital.

Dr O. Rosenheim (F.R.S. 1927) is one of the biochemical workers at the Laboratories of the Medical Research Council at Hampstead. He was formerly at King's College, London.

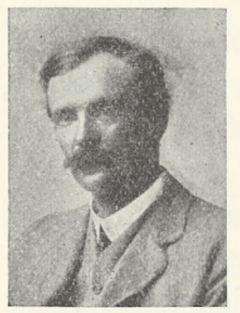

Dr Keith Lucas (F.R.S. 1913) was one of the most brilliant of the younger Cambridge physiologists, distinguished for his knowledge of physics and its applications to the problems of Physiology. He was killed in the War in a flying accident, to the great loss of his country and of science and the regret of his friends and colleagues.

It was proposed by Dr J. S. Haldane, seconded by Professor Halliburton, and carried unanimously "that this Society gives its hearty support to the recommendations of the Committee appointed by the Government to consider the Humane Slaughtering of Animals."

The Secretary was requested to forward copies of this resolution to The Times and to the Secretary of the Committee in question.

August 19th, 1904 (at Cambridge). An extra meeting was held at Cambridge during the meeting there of the British Association. At this meeting, besides other communications, papers were read by Professor 
A. Kossel of Heidelberg, Professor Nicloux (of Paris, now at Strasburg) and Professor W. B. Cannon of Harvard. There were thirty-four members and nineteen guests at the dinner, which was held in the Hall of Downing College, the Master, Dr Alexander Hill, being in the chair. The members present were: Myers, Copeman, Russell, Dixon, Brodie, Shore, Hopkins, Waller, Cole, Macdonald, Mann, Macallum, Fletcher, Elliott, Anderson, Head, Rivers, Gaskell, Schäfer, Sherrington, Hill, Barcroft, Cunningham, Grünbaum, Thompson, Hardy, Halliburton, Harden, Ewart, Eyre, Page May, Vernon, Schryver, Woodhead. The guests included Professors Johansson (Professor of Physiology in Stockholm), Sedgewick Minot (Professor of Embryology at Harvard), Atwater, Kossel (Professor of Physiology in Heidelberg), Nicloux (Paris), Camus (Paris), Körösy (Budapest), Cannon (Harvard) and Wesley Mills (Montreal).

January 21st, 1905 (at King's College). Dinner at the Hotel Cecil with Professor Halliburton in the chair. Twenty-four other members and four guests were present. This was the Annual General Meeting.

The Secretaries' Report showed an ordinary membership of 234 .

The Treasurer's Report showed a credit balance of $£ 29$. 18s. $1 d$., after $£ 263$. 13 s. $6 d$. had been invested in the purchase of $£ 300$ Consols.

The following new members were elected: E. Frankland Armstrong (London), E. Barclay-Smith (Cambridge), W. Cramer (Edinburgh), H. D. Dakin, E. S. Edie, C. Ham, H. E. Roaf and W. B. Warrington.

Dr E. Frankland Armstrong (F.R.S. 1920), himself a distinguished chemist, is the son of Professor H. E. Armstrong, the eminent chemist, who became a Fellow of the Royal Society as long ago as 1876.

Dr E. Barclay-Smith is Professor of Anatomy in King's College, London.

Dr H. D. Dakin (F.R.S. 1917) was at that time working at the Lister Institute, but is now settled in New York.

Mr E. S. Edie was at the Biochemical Laboratory, Liverpool. $\mathrm{He}$ is now Professor at the University of Cape Town.

Dr C. E. Ham was Demonstrator of Chemical Physiology at the London Hospital Medical School.

Dr H. E. Roaf was Lecturer in Chemical Physiology in Liverpool University, and afterwards Lecturer on Physiology at St Mary's Hospital Medical School. He is now Professor of Physiology at the London Hospital Medical School, and is at present one of the Honorary Secretaries of the Society. 
A resolution was passed amending the rule regarding the length of communications, which are in future not to occupy more than fifteen minutes.

May 20th, 1905 (at Cambridge). Dinner at St John's College with Professor Langley in the chair; there were forty-two other members and seven guests, the latter including Professor Cushny and Dr Barger.

Dr Henry Head brought before the Society certain proposals with regard to amalgamation with the Medical Societies of London. After an informal discussion the question was adjourned to the next meeting.

June 17th, 1905 (at the University of London). Dr Waller took the chair at the dinner: there were eleven other members and four guests.

It was resolved to refer the question of amalgamation with the Medical Societies of London to the Committee to consider and report.

July 1st, 1905 (at Oxford). Dinner at Magdalen College, Professor Gotch in the chair. There were twenty-nine other members present and five guests.

The question of dealing adequately with the increasing number of communications was discussed: it was left to the Committee to consider and report to the Society.

Six new members were elected at this meeting: E. Whitley, J. M. Hamill, W. A. Jolly, F. H. A. Marshall, Chalmers Watson and A. R. Cushny.

Dr W. A. Jolly was Assistant to the Professor of Physiology, Edinburgh. He is now Professor of Physiology in the University of Cape Town.

Dr F. H. A. Marshall (F.R.S. 1920) was working in the Physiology Laboratory of the University of Edinburgh. He is now Lecturer on Physiology as applied to Agriculture in the University of Cambridge.

Dr Chalmers Watson, an Edinburgh physician, was at this time working in the Physiology Department of the University.

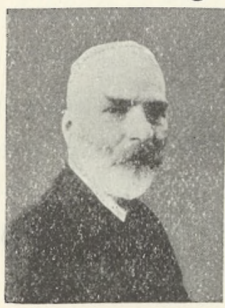

Dr A. R. Cushny (F.R.S. 1907) was for some years Professor of Pharmacology in the University of Michigan, Ann Arbor, and subsequently in University College, London. In 1918 he was appointed to the chair of Materia Medica and Pharmacology in the University of Edinburgh, and held this appointment until his death in 1926 . 
November 11th, 1905 (at Guy's Hospital). Dr Pye-Smith in the chair. There were thirty members and five guests. The latter included Professor Koch and Dr Fr. Müller of Berlin.

December 16th, 1905 (at St Mary's). The death of Sir John Burdon Sanderson, one of the founders and original members of the Society, and a very frequent attendant at the meetings, was announced and, on the motion of the chairman, Dr Waller, the following resolution was adopted, the members present rising in their places: "The Physiological Society desires to express its deep sense of the loss it has suffered by the death of its oldest and most distinguished member John Burdon Sanderson, whose life-long devotion to science remains in the memory of every member of the Society as an incentive and an example. The Society offers to Lady Burdon Sanderson its heartfelt sympathy." The letter of acknowledgment and thanks sent by Lady Sanderson in reply to this resolution is preserved in the Minute Book.

January 20th, 1906 (at King's College). At the Annual Meeting for 1906 held at the Hotel Cecil with Professor Halliburton in the chair, there were forty other members and two guests, Major Hall, D.S.O., and Dr Paul Haas.

The Secretaries, after referring to the loss the Society had sustained by the death of Sir John Burdon Sanderson, and also to the death of Dr Bullot, reported that fourteen new members had been elected during the past year and four members had resigned. There were now 240 members, exclusive of Honorary Members.

The Treasurer reported a credit balance of $£ 35$. $6 s .6 \mathrm{~d}$.

The Officers having been re-elected and the Committee elected, $\mathrm{Mr}$ G. P. Mudge (London Hospital) and Dr V. E. Henderson (Toronto) were admitted members of the Society. A committee, consisting of Professor Halliburton, Drs Hopkins, Aders Plimmer, Ramsden, Schryver and B. Moore, was appointed to consider and report on the nomenclature "of the bodies now known as Proteids," and was instructed to ask the Chemical Society to appoint a committee of its members to confer with those appointed by the Physiological Society.

March 24th, 1906 (at University College). Dinner at Pagani's Restaurant. Professor Starling was in the chair, and there were present twenty-five other members and five guests.

This was a Special General Meeting to consider certain proposed changes in the rules dealing with communications at the meetings. The 
changes concerned the order and length of communications, and were agreed to.

The report on protein nomenclature was presented to the Society, but its adoption was deferred. It is preserved in the Minute Book. The main recommendation was the substitution of the term "protein" for "proteid": the former term being already in use in America and Germany. Many of the recommendations in the original report were subjected to considerable criticism, and a modified report, which is also preserved in the Minute Book, was adopted by the Society at its meeting in January 1907, and was ordered to be published in the Journal of Physiology amongst the Proceedings of the Society, where it may be consulted.

On March 21st, 1908, at a meeting at University College, London, the question of protein nomenclature was again raised in connexion with the recommendations of the American Physiological Society on the same subject, and it was agreed to ask the Committee to report to a further meeting regarding these recommendations. At the meeting at Cambridge in May of the same year (1908) the report was presented. This report gave reasons for dissenting from such of the recommendations of the American Physiological Society as differed from those of the Physiological Society.

May 12th, 1906 (at Cambridge). Dinner in St John's College. Professor Langley was in the chair: there were in addition thirty-five members and seven guests.

Professor Langley informed the Society of action taken by the Committee in appointing a special sub-committee for the purpose of conferring with other bodies so that evidence on behalf of experimental medicine might be appropriately brought before the proposed new Royal Commission on Vivisection. The meeting signified its approval, and also agreed that the funds of the Society might be used to defray necessary expenses.

June 2nd, 1906 (at Edinburgh). The scientific communications (twentysix in number) were taken in the morning, commencing at 9.30. The afternoon was spent at North Berwick. After taking tea at Professor Schäfer's residence (Marly Knowe) the members travelled back to Edinburgh and held the dinner meeting in the evening at the North British Station Hotel, Professor Schäfer in the chair. There were present thirty-six members and thirty-one guests. Amongst the latter were the Principal, Sir William Turner, Professor McPhedran of Toronto, Professors 
Cunningham (Anatomy), Greenfield (Pathology), Littlejohn (Forensic Medicine) and Ewart (Natural History), and Drs Pringle, Russell, Goodall, Lochhead, John Tait, A. N. Bruce, Beattie, Fleming, Shennan, Dickson, Mrs Chalmers Watson, Miss Sowton, Mrs Thompson, Miss Eaves and Miss Mitchell. Many of these afterwards joined the Society.

This appears to have been the first occasion on which ladies were present at a dinner of the Society.

June 30th, 1906 (at Oxford). The dinner was at Magdalen College, Professor Gotch in the chair. There were present twenty-five members and nine guests, amongst the latter Professor H. E. Armstrong (p. 132) and Professor Sir William Osler.

The thanks of the Society were voted to Dr Ludwig Mond for his gift of a large steel chamber to the Lister Institute for investigating the effects of rarefied and compressed gases.

Professor Starling reported that a Committee was dealing with the matter of bringing evidence before the proposed new Royal Commission on Vivisection. He invited the Society to hold a Special Meeting on September 29th at University College, London, to meet Professor I. P. Pavlov, who was visiting London to deliver the Huxley Memorial Lecture.

There is no record of a dinner on that occasion nor of any communication from Professor Pavlov, who was however present at the scientific meeting on that date.

The new members elected included D. Forsyth, M. Greenwood, C. Gordon Douglas (Oxford), L. Noon, J. A. Gardner and John Tait.

Dr David Forsyth is Physician to Charing Cross Hospital.

Mr Major Greenwood was Demonstrator of Physiology at the London Hospital. He is now Professor of Epidemiology and Vital Statistics at the London School of Hygiene and Tropical Medicine.

Dr C. Gordon Douglas, C.M.G., M.C. (F.R.S. 1922), is a Fellow of St John's College, Oxford.

Dr L. Noon was working at the Pathological Laboratory, Cambridge, and was afterwards in charge of the Medical Inoculation Department of St Mary's Hospital. He died in 1913.

Dr John Tait was Assistant and Lecturer in the Physiology Department of Edinburgh University. He was appointed in 1919 to the Chair of Physiology in McGill University, Montreal. 
January 26th, 1907 (at King's College). Annual General Meeting. The dinner was at the Hotel Cecil, Professor Halliburton in the chair. Neither the names nor the number of those present are recorded in the minutes. This seems now to be the regular practice.

The Secretaries' Report shows a membership (ordinary) of 241, with eight Honorary Members. The Treasurer's Report shows a credit balance of $£ 93.7 s .8 d$.

After the election of Officers and Committee, the following resignations were reported and accepted, "with much regret": Dr Walker Hall, Dr Hédon (Hedin), Mr Horder, Dr Klein (one of the original members) and Sir Thomas Stevenson.

Dr F. S. Scott ${ }^{1}$ and Dr Chas Bolton were elected members.

Dr F. H. Scott is Professor of Physiology in the University of Minnesota, Minneapolis.

Dr Chas Bolton (F.R.S. 1918) is Physician to University College Hospital; formerly Lecturer in General Pathology in the Medical School.

Professor Starling presented the report of the Vivisection Committee (p. 136), and proposed that the Honorary Treasurer be empowered to hold a sum not exceeding $£ 100$ at the disposal of the Vivisection Committee. This was seconded by Dr Waller and carried.

It was proposed by Professor Halliburton and seconded by Dr Hopkins and carried that the Report of the Protein Nomenclature Committee be provisionally approved by the Society. An amendment to postpone approval until the opinion of the American Physiological Society upon the subject had been received was lost, and the Report was directed to be published in the Proceedings with a note that it had been provisionally approved. Dr Hopkins was requested to circulate the Report in English, French, German and Italian, with the view of bringing it up for consideration at the forthcoming International Physiological Congress.

This was an amended report (p. 135): it is inserted in the Minute Book, as is a letter from the Secretary of the American Physiological Society.

February 23rd, 1907 (at the Lister Institute). At this meeting the death of Sir Michael Foster was reported. On Professor Sherrington's proposal an expression of the deepest sympathy with Lady Foster was adopted.

Lady Foster's letter in reply is preserved in the Minute Book.

1 Should be F. H. Scott. 
March 23rd, 1907 (at University College). Professor Starling in the chair.

It was decided to send out notices regarding the forthcoming International Physiological Congress.

Mr Symes was asked to undertake the cataloguing of British physiological literature for the International Catalogue, in place of Dr Forsyth, resigned.

June 22nd, 1907 (at Oxford). Dinner in Magdalen College with Professor Gotch in the chair. The following were elected members of the Society: T. S. Hele (Cambridge), Alex. Goodall (Edinburgh), W. A. Aikin (London), P. Hartley, H. S. Raper, A. F. Herz (Guy's), W. J. Young, P. P. Laidlaw, J. Mellanby.

Dr T. S. Hele, O.B.E., is Fellow and Lecturer in Emmanuel College, Cambridge.

Dr A. Goodall is Lecturer on Physiology in the Extramural School, Edinburgh.

Dr P. Hartley is an Assistant at the Laboratories of the Medical Research Council, Hampstead. He was formerly at the Lister Institute.

Dr H. S. Raper was formerly Professor of Physiology and Biochemistry in Leeds University, and now occupies the same position in the Victoria University, Manchester.

Dr A. F. Her z (who has changed his name to Hurst) was Demonstrator of Physiology at Guy's and is now Physician to Guy's Hospital.

Dr W. J. Young was at the Lister Institute and is now at the University of Melbourne.

Dr J. Mellanby is Professor of Physiology at St Thomas's Hospital Medical School, and is editor, for the Society, of Physiological Abstracts.

At the other meetings in 1907 only the titles of communications made at the scientific meetings are recorded: there was no private business and the names of members and guests are not given in the minutes.

January 25th, 1908 (at King's College). Annual General Meeting. Dinner at the Hotel Cecil, Professor Halliburton in the chair. The Secretaries' Report for 1907 makes special reference to the great loss the Society has suffered in the death of its "chief originator," Sir Michael Foster. The Report also refers to the death of Mr F. J. M. Page, a "member of many years' standing." A vote of condolence with his 
relatives was adopted by the Society. The roll of ordinary members is 240 besides eight Honorary Members.

The Treasurer's Report shows the satisfactory balance of $£ 167$. $4 s .3 d$. The Committee was empowered to utilise the invested funds of the Society in payment of lectures on the value of vivisectional methods. There is no evidence that advantage was taken of this permission.

It was agreed to continue the annual grant of ten pounds towards the expense of cataloguing British physiological literature for a further period of five years.

The following were elected members: W. H. Harvey, Harold Pringle, J. C. G. Ledingham, A. W. Sikes, P. Hamill, Fr. Müller, D. H. de Souza, Captain G. C. C. Damant, R.N.

Dr W. H. Harvey is an Assistant in the Pathological Laboratory at Cambridge.

Dr Harold Pringle was Assistant in the Physiology Department of the University of Edinburgh. He is now Professor of the Institutes of Medicine in Trinity College, Dublin.

Dr J. C. G. Ledingham, C.M.G. (F.R.S. 1921), is Professor of Bacteriology at the Lister Institute.

Dr P. Hamill is Lecturer on Pharmacology and Therapeutics in St Bartholomew's Medical School.

Dr A. W. Sikes was a Lecturer on Physiology in King's College.

Dr Franz Müller is Professor of Pharmacology in Berlin.

Dr D. H. de Souza was attached to the Physiological Department of University College. He is now Lecturer in Physiology at King's College, London, and Physician to Westminster Hospital.

March 21st, 1908 (at University College). Professor Starling in the chair.

$£ 100$ was voted from the funds of the Society to the Treasurer of the Research Defence Society (for combating anti-vivisection).

This was made a Special Meeting in order to effect certain changes in the rules, dealing with the length both of communications and of speeches during discussions.

June 20th, 1908 (at Oxford). Dinner at Magdalen College, with Professor Gotch in the chair.

Mr W. M. Bayliss was appointed to represent the Society at the celebration of the fiftieth anniversary of the Oxford Museum.

The following new members were elected: A. Mavrogordato, J. H. 
Ryffel, A. G. Levy, A. C. H. Rothera (Melbourne), O. T. Williams, R. W. Goadby ${ }^{1}$, H. W. Bywaters, J. Mackenzie.

Mr J. H. Ryffel is Reader in Biochemistry at Guy's Hospital Medical School.

Dr A. G. Levy was Anæsthetist to Guy's Hospital and Pathologist to the London Temperance Hospital. He is Physician to the City of London Hospital for Diseases of the Chest.

Dr O. T. Williams was Assistant in the Biochemical Department of Liverpool University. He died in 1910.

Sir Kenneth Goadby, K.B.E., is Lecturer on Bacteriology to the London Dental Hospital, and Medical Referee to the Home Office.

Sir James Mackenzie (F.R.S. 1915) is the eminent authority on cardiac diseases, founder of the Mackenzie Institute at St Andrews. He died in 1925.

December 19th, 1908 (at Liverpool). The Society met for the first time at Liverpool on the invitation of Professor Sherrington. The dinner was at the University Club with Professor Sherrington in the chair. A letter from Dr R. Caton-one of the original members of the Society-was read expressing his regret at being unable personally to welcome the Society to Liverpool.

January 23rd, 1909 (at King's College). Annual General Meeting. Dinner at the Hotel Cecil, Professor Halliburton in the chair.

The Secretaries' Report shows a roll of 248 ordinary members.

- The Treasurer's Report shows a credit balance of $£ 185$.

Dr J. B. Leathes was elected one of the Secretaries in place of Dr T. G. Brodie who was resigning on his appointment to the Chair of Physiology at Toronto ${ }^{2}$, Mr W. M. Bayliss remaining as the other Secretary and Dr A. D. Waller as Treasurer.

Professor Hans Meyer and Professor I. P. Pavlov were elected Honorary Members.

An address of congratulation to Professor Hugo Kronecker on the celebration of his seventieth birthday was adopted, and he was also elected an Honorary Member.

1 Should be "K. W. Goadby."

${ }^{2}$ A memento-subscribed for by individual members of the Society-was presented to Dr Brodie on this occasion. The names of the subscribers are preserved in the Minute Book. The amount subscribed was £97. $0 s .6 d$. 
The following new members were elected: E. L. Kennaway, S. G. Scott (Oxford), C. Spearman, G. C. Mathison (Melbourne), T. Graham Brown, C. C. Lieb (New York), W. H. Hurtley (St Bartholomew's), Georges Dreyer.

Dr E. L. Kennaway was Demonstrator of Physiology at Guy's Hospital and afterwards Chemical Pathologist to the Bland Sutton Institute, Middlesex Hospital. He is now Chemical Pathologist to the Research Institute at the Cancer Hospital.

Dr C. Spearman is Grote Professor of Mind and Logic in University College.

Dr T. Graham Brown (F.R.S. 1927) is Professor of Physiology at Cardiff, where he succeeded Professor Haycraft. He is the son of Dr J. Graham Brown who had been a member since 1899.

Dr G. C. Mathis on was killed at Gallipoli in 1915.

March 27th, 1909 (at University College). Dinner at the Great Central Hotel with Professor Starling in the chair. Professor Kronecker was present at the dinner and thanked the Society for their address and for electing him an Honorary Member.

May 15th, 1909 (at Cambridge). Dinner at Trinity College, Professor Langley in the chair. The deaths of Professor Arthur Gamgee, F.R.S., and of Professor Gerald Yeo, F.R.S., were reported and resolutions expressing the sympathy of the Society with Mrs Gamgee and Mrs Yeo were adopted.

The question of a presentation on behalf of the Society to Dr F. W. Pavy, one of the original members, on the occasion of his eightieth birthday was discussed and the Committee was instructed to consider the matter.

June 5th, 1909 (at Glasgow). A meeting of the Society was held here for the first time on the invitation of Professor Noël Paton. Dinner was in the University Union.

June 26th, 1909 (at Oxford). Dinner in the Junior Common Room of Magdalen College, Professor Gotch in the chair.

Dr Leathes having been compelled to give up his Secretaryship on his appointment to a chair at Toronto, Mr Barcroft was requested to act for him during the remainder of the session.

The presentation of an address and piece of plate to Dr Pavy was made by the Chairman on behalf of the Society "in commemoration of 
his eightieth birthday and his prolonged devotion to physiological research." Dr Pavy made a suitable acknowledgment.

The following were elected members of the Society: "J. Sholto Douglas (Birmingham), E. P. Poulton, Mario Camis, V. M. Mottram¹, F. O'B. Ellison, J. Foster Gaskell, G. Barger, E. Mellanby."

Dr Sholto Douglas is now Professor of Pathology in the University of Sheffield.

Dr E. P. Poulton is now Physician to Guy's Hospital.

Dr Mario Camis is Professor of Physiology at Parma, Italy.

Dr V. H. Mottram is Professor of Physiology at King's College for Women, London.

Dr Ellison is Professor of Physiology in the Medical College, Colombo.

Dr G. Barger (F.R.S. 1919) was at that time working at the Wellcome Pharmacological Laboratory: transferring afterwards to the Medical Research Council's Laboratory. Since 1919 he has been Professor of Chemistry in relation to Medicine in the University of Edinburgh.

Dr E. Mellanby (F.R.S. 1925) is Professor of Pharmacology in the University of Sheffield.

October 23rd, 1909 (at St Mary's). Dinner at the Great Central Hotel with Dr Alcock in the chair.

The minutes contain the following: "Mr G. N. Knox, present as a guest, having explained the new system of the Standard newspaper with regard to the publication of information respecting higher scientific teaching and research it was referred to the Committee in consultation with Mr Knox to report on it as far as it affects the Physiological Society." Nothing more seems to have come of this.

January 22nd, 1910 (at King's College). Annual General Meeting. Dinner at the Hotel Cecil, Professor Halliburton in the chair.

The name A. V. Hill appears for the first time in the Minute Book (as introduced by J. Barcroft).

Dr A. V. Hill, O.B.E. (F.R.S. 1918), successively Professor of Physiology in Manchester and in University College, London, is now a Royal Society Foulerton Professor, working at University College, London. Previous to his appointment to Manchester he was a Lecturer in Physiology and Physical Chemistry at Cambridge. He joined the Society in 1912. He received a Nobel Prize for Medicine in 1922 .

1 Should be "V. H. Mottram." 
The deaths of Professor Engelmann, an Honorary Member, and of W. Page May, an ordinary member of the Society, were reported. A resolution of sympathy with Mrs May was proposed by the Chairman and adopted.

The Secretary reported that seven resignations had been received and sixteen new members had been elected during 1909, making the roll of the Society 253 ordinary and ten Honorary Members. Eight meetings had been held in the year.

The Treasurer's Report shows a credit balance of $£ 162.13 \mathrm{~s} .11 d$.

Professor Emil Fischer (Berlin) was elected an Honorary Member ${ }^{1}$.

The following were elected Officers and Committee for 1910:

Hon. Treasurer, Dr Waller.

Hon. Secretaries, W. M. Bayliss and J. Barcroft.

Committee: E. P. Cathcart, A. R. Cushny, F. Gotch, W.D. Halliburton, J. B. Haycraft, Leonard Hill, F. G. Hopkins, J. N. Langley, C. J. Martin, B. Moore, M. S. Pembrey, W. Ramsden, E. A. Schäfer, C. S. Sherrington, E. H. Starling.

The following were elected members: G. R. Mines, William Osler, Hugh Maclean, Frederick Ransom.

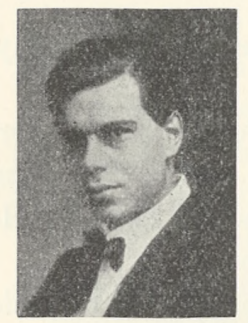

Dr G. R. Mines was at the time Demonstrator on Physiology at Cambridge and one of the most brilliant of the younger physiologists. He was subsequently appointed to the chair of Physiology at McGill University, Montreal, but only held it a short time. He died in 1914.

Sir William Osler was successively Professor of Physiology in McGill University, Montreal (18751884), Professor of Medicine in the University of Pennsylvania, Philadelphia (1884-1888), Professor of Medicine in the Johns

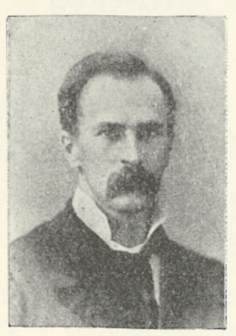
Hopkins University, Baltimore (1888-1905), and Regius Professor of Medicine in the University of Oxford (in succession to Sir John Burdon Sanderson) from 1905 until his death. Osler was elected a Fellow of the Royal Society in 1898. He was created a baronet in 1911. He died on December 29th, 1919, at the age of 70. His Life, by Harvey Cushing of Boston, is a fascinating study, and shows, amongst other things, what an important influence a preliminary training in

1 His letter acknowledging the honour is referred to in the minutes of the meeting of March 19th, 1910, but it has not been preserved in the Minute Book. 
Physiology may exercise over a career devoted to Pathology and Clinical Medicine. Similarly the Life of Lord Lister, by Rickman J. Godlee, and that of Victor Horsley, by Stephen Paget, show the advantage of such a training to a career devoted to Surgery.

Dr Hugh Maclean was at that time working in the Biochemical Laboratory of the University of Liverpool. He is now Professor of Medicine and Physician to St Thomas's Hospital.

Dr F. Ransom was Professor of Pharmacology at the London School of Medicine for Women.

March 10th, 1910 (at University College). Dinner at the Great Central Hotel, Professor Starling in the chair.

The Report of the Committee as to the Proceedings of the Society was received, but its adoption was deferred to a Special Meeting, since it necessitated a change in the rules.

June 18th, 1910 (at Oxford). Dinner was in the Hall of Pembroke College, Professor Gotch in the chair.

The following new members were elected: William Brown, Martin Flack, David A. Welsh, F. W. Edridge-Green, R. H. Clarke.

Dr William Brown is Wilde Reader in Mental Philosophy in the University of Oxford.

Dr Martin Flack was working with Professor Kronecker in Bern and later was associated with Dr Leonard Hill at the Department of Physiology of the London Hospital Medical School. He is now Director of Research in the Royal Air Force.

Dr Welsh was formerly Assistant to the Professor of Pathology (Professor Greenfield) in Edinburgh. $\mathrm{He}$ is now Professor of Pathology in Sydney.

Dr Edridge-Green, C.B.E., is Examiner and Adviser on Colour Vision to the Board of Trade.

December 17th, 1910 (at Liverpool). Dinner was in the University Club, with Professor Sherrington in the chair. The minutes record that "the Society was honoured by the presence of Professor Caton."

The death of Professor Angelo Mosso having been reported, the Secretaries were instructed to send a letter of condolence to Signora Mosso.

The congratulations of the Society were sent to Professor Kossel on the occasion of his receiving the Nobel Prize. 
"The following members were present at the meeting: Messrs Roaf, Graham Brown, Boyce, Mines, Wakelin Barrett, A. S. Grünbaum, B. Moore, Bayliss, Aders Plimmer, H. G. Plimmer, Gotch, Barcroft, Paton, Cathcart, Schryver, Schäfer, Horsley, Alcock, Macdonald, and Lorrain Smith. And the following guests: Sir James Barr, M.D., Mr William Johnston (donor of the Johnston Laboratories), Professors Donnan, Baly, Elliott Smith, Herdman, Dr Warrington, Capt. Carter, Dr Dakin, Dr Owen, Mr Cyril Burt, Dr Yorke, Mr Arnold, Miss Sowton, Miss H. Chick, Mrs Roaf, Miss Hanley, Mrs A. S. Grünbaum, Professor Oskar Vogt and Mrs O. Vogt."

Professor F. G. Donnan, C.B.E., F.R.S., is now Professor of General Chemistry in University College, London.

Professor E. C. C. Baly, C.B.E., F.R.S., is Professor of Inorganic Chemistry in the University of Liverpool.

Professor Herdman, F.R.S., afterwards Sir William Herdman, was Professor of Natural History and afterwards of Oceanography in the University of Liverpool. He died in 1925.

Dr Owen is probably Dr John Owen, Physician to the Royal Infirmary, Liverpool.

Dr Yorke is probably Dr Warrington Yorke, Professor of Parasitology in Liverpool.

Miss Sowton was working with Professor Sherrington at Liverpool on the isolated mammalian heart; she afterwards joined Dr Waller at the University of London. She became a member in 1915.

Miss Harriet Chick is Assistant at the Lister Institute. She joined the Society in 1918.

Professor Oskar Vogt is Professor of Physiology in the Institut für Hirnforschung, Berlin.

January 21st, 1911 (at King's College). Annual General Meeting. The Secretaries' Report records the death during the past year of one of the Honorary Members, Professor Pfluiger, and one of the most distinguished. ordinary members, Dr Sydney Ringer.

The number of members is now 253; besides ten Honorary Members.

The Treasurer's Report shows a credit balance of 1168 . 11s. $3 d$.

The Officers and Committee were elected, and also three new members, namely, G. H. Clark, C. M. Hinds Howell, D. McCay.

Dr G. H. Clark is Research Assistant to the Professor of Materia Medica, Glasgow.

$\mathrm{PH}$. 
Dr C. M. Hinds Howell is Assistant Physician to St Bartholomew's Hospital and Physician for Outpatients to the National Hospital for the Paralysed and Epileptic.

Lt.-Col. D. McCay is Professor of Materia Medica and Clinical Medicine at the Medical College, Calcutta.

The Society agreed to contribute $£ 20$ a year for five years to assist the cataloguing of British physiological literature.

Certain regulations were adopted relative to the publications of papers in the Proceedings, and the consequent changes in the rules were agreed to.

June 3rd, 1911 (at Edinburgh). The scientific meeting was held in the morning in the Physiological Laboratory. After lunch the members travelled to North Berwick and spent the afternoon at Marly Knowe. The dinner meeting was at the Royal Hotel, North Berwick, with Professor Schäfer in the chair, thirty-two members and guests being present ${ }^{1}$. Amongst the latter were Professor Einthoven of Leiden, introduced by the Chairman, and Dr Krause of Philadelphia and Dr Williams of New York, both introduced by Sir Victor Horsley.

July 1st, 1911 (at Oxford). Dinner at Magdalen College with Professor Gotch in the chair. The following were elected members of the Society: Drs Mackenzie Wallis, Judah L. Jona (Melbourne), E. Frankland Armstrong, F. W. Lamb, C. Lovatt Evans, Walter J. Dilling, and James A. Gunn.

Dr Mackenzie Wallis was Lecturer on Chemical Pathology at St Bartholomew's Hospital.

Dr F. W. Lamb is now Reader in Physiology in the University of Manchester.

Dr C. Lovatt Evans (F.R.S. 1925) is Jodrell Professor of Physiology in University College, London; he previously held a similar office at St Bartholomew's Medical College.

Dr W. J. Dilling is Lecturer on Pharmacology in the University of Liverpool.

Dr James A. Gunn is Professor of Pharmacology in the University of Oxford. At this time he was Assistant to the Professor of Materia Medica in Edinburgh.

July 22nd, 1911 (at the University of London). This meeting is memorable as the last occasion on which Dr Pavy made a communication to

1 The ladies of the party, including Mrs Einthoven, Mrs Williams, Lady Horsley, and Mrs Brodie, dined at Marly Knowe. 
the Society. In conjunction with $\mathrm{Mr}$ W. Godden he showed the inhibitory influence of dilute sodium carbonate solution upon the post mortem production of sugar in the liver and upon the production of glycosuria by chloroform and nerve stimulation.

October 21st, 1911 (at Guy's Hospital). Dinner in the Students' Club, with Dr Pembrey in the chair. Since the last meeting in July, at which he made the above communication, Dr Pavy had died (at the age of 80). The Chairman proposed and Dr Haldane seconded a resolution expressing the regret of the Society, and desiring the Secretary to convey a message of condolence to his relatives.

January 20th, 1912 (at King's College). Annual General Meeting. Dinner at the Howard Hotel, Professor Halliburton in the chair.

The Secretaries reported the death during the year of several distinguished members, namely, Professor Sir Rubert Boyce, Dr Alexander Bruce, Dr Hughlings Jackson, Dr MacMunn and Dr Pavy. The number of members is now 266. Ten meetings were held during the year.

The Treasurer's Report showed a credit balance of £172. 9s. 8d.

The Officers and Committee having been appointed, the following new members were elected: W. Burridge, Yandell Henderson, A. V. Hill, J. A. Menzies, F. P. Knowlton.

Dr W. Burridge is Professor of Physiology in the University of Lucknow.

Dr Yandell Henderson is Professor of Applied Physiology in Yale University, New Haven, U.S.A.

Dr F. P. Knowlton is Professor of Physiology in Syracuse, N.Y., U.S.A.

A report was read from the standing committee on Education suggesting that the Board of Education should be approached, if possible by a deputation, in order to urge that biological subjects, and especially Physiology, should be continued to be recognised as essential for the teaching of Public Health and Psychology. The Board was apparently about to drop these subjects out of the curriculum. The report was adopted and Sir Victor Horsley and the Secretaries of the Society were added to the committee. Professor Brodie's name was deleted, since he was now in Canada and unable to attend the meetings.

March 16th, 1912 (at University College). Dinner at the Endsleigh Palace Hotel, Professor Starling in the chair.

It was proposed by Dr Waller and seconded by Sir Victor Horsley 
that the Report of the Royal Commission on Vivisection be referred to the Committee for consideration and report. This was adopted.

June 29th, 1912 (at Oxford). Dinner at Magdalen College, with Professor Gotch in the chair.

Professor Tigerstedt of Helsingfors was present as a guest.

Four new members were elected, namely, Drs H. J. Hutchens (Newcastle), V. W. Draper (King's College), N. Mutch (Guy's) and F. Cook (Guy's).

Dr H. J. Hutchens, D.S.O., is Professor of Comparative Pathology and Bacteriology in the University of Durham School of Medicine, Newcastle-on-Tyne.

Dr N. Mutch is Assistant Physician and Lecturer on Pharmacology in Guy's Hospital.

Mr Frank Cook, F.R.C.S., is Assistant Obstetric Surgeon to Guy's Hospital.

It was proposed by Dr Leonard Hill, seconded by Professor G. Thane, and carried "That the question of unification of physiological and anatomical nomenclature of the central nervous system be referred to a Committee for consideration and report." The personnel of this committee was left to the Committee of the Society for selection.

An address ${ }^{1}$ which it was proposed to send to the Medical School of Trinity College, Dublin, on the occasion of the two-hundredth anniversary of its foundation, was read to the Society, and was ordered to be signed by the Chairman and the Secretaries. One of the Secretaries, Mr J. Barcroft, was appointed to represent the Society at the celebration.

July 27th, 1912. This meeting was held at Liverpool on the invitation of Professors Sherrington and Benjamin Moore. No private business is recorded as having been transacted either at this meeting, or at the remaining meetings for 1912. Nor are the names of those present preserved.

January 18th, 1913 (at King's College). Annual General Meeting. Dinner at the Howard Hotel, with Professor Halliburton in the chair.

The Secretaries' Report for 1912 records the death of "a very distinguished Honorary Member, Lord Lister." Also that "the Society's list is at present nine Honorary and 259 ordinary members, a net increase of four on the corresponding numbers of last year ${ }^{2} . "$

1 The address, which is somewhat lengthy, is in the Minute Book.

2 But the report for the preceding year gives 266 as the number of members! 
Four members had resigned and nine had been elected. Ten meetings were held in 1912.

The Treasurer's Report shows a credit balance of £169. 12s. $6 d$.

The Education Committee of the Society, having sent a memorandum to the Board of Education dealing with the position of Physiology in Education, subsequently formed a deputation to the Board. The memorandum is printed in the Supplement to the British Medical Journal of May 25th, 1912. The deputation consisted of Victor Horsley, Sherrington, Starling, Waller, Bayliss, Myers and Edkins, and was introduced by Dr C. Addison, M.P. It was received by the President of the Board of Education, the Rt. Hon. J. A. Pease, the Chief Medical Officer, Sir George Newman, the Parliamentary Secretary, Mr Charles Trevelyan, and other members of the Board, and the points raised in the memorandum were enforced by Sir Victor Horsley, Professor Sherrington, Dr Edkins and Dr Myers. The Board, however, declined to make any change, or to withdraw the circular complained of, and do not seem to have attempted to deal with the arguments of the above speakers, who urged the necessity for a training in Physiology for the understanding of Hygiene and Psychology.

After the appointment and re-appointment of the Committee and Officers of the Society ten new members were elected as follows: R. A. Krause (Edinburgh), Aug. Krogh, Casimir Funk, H. R. Dean, William Ray (Oxford), C. H. O'Donoghue, A. J. Clark, H. H. Hartridge, H. L. Tidy, C. G. L. Wolf (Cambridge).

Dr R. A. Krause was working in the Physiology Department of the University of Edinburgh. He is now the chief Medical Officer of the Fife Education Authority.

Dr August Krogh is Professor of Animal Physiology in the University of Copenhagen. He was awarded the Nobel Prize for Medicine in 1920.

Dr Casimir Funk was working at the Lister Institute. He is now at the State Epidemiological Institute, Warsaw.

Dr C. H. O'Donoghue was until recently Professor of Zoology at Winnipeg. He is now Lecturer on Zoology in Edinburgh University. He was at this time working at University College.

Dr A. J. Clark was at the time Assistant to Professor Cushny at University College. He afterwards was successively Professor of Pharmacology at Cape Town and at University College, London, and 
he now holds the same office at the University of Edinburgh, where he succeeded the late Professor Cushny.

Dr H. Hartridge (F.R.S. 1926) was until lately Lecturer in Special Senses at Cambridge. He is now Professor of Physiology at St Bartholomew's Medical School.

Dr H. L. Tidy is Assistant Physician to St Thomas's Hospital.

Dr Wolf is Biochemist to Addenbrooke's Hospital, Cambridge.

At this meeting it was proposed by Dr Haldane and seconded by Dr Cathcart that "it is desirable that women should be regarded as eligible for membership of the Society." The following amendment was proposed by Dr Roaf and seconded by Professor Noël Paton: "that the Committee be instructed to circularise the members of the Society on the question." The amendment was lost, the original motion was carried, sixteen voting for and thirteen against ${ }^{1}$.

March 15th, 1913 (at University College). Dinner at the Grafton Hotel, Professor Starling in the chair.

It was proposed by Professor Halliburton, seconded by Professor Waller, and carried "that the Society make a donation of ten guineas to the Lister Memorial Fund."

The Chairman proposed that there should be a meeting of the Society at the time of the International Medical Congress, and that the foreign members of the Physiology Section should be invited to dine with the Society. On the motion of Professor Halliburton, seconded by Professor Bayliss, it was agreed to refer the matter to the Committee to report to the Society.

No further mention of this occurs in the Minute Book, except a brief allusion to the dinner in the Secretaries' Report at the ensuing Annual Meeting. But from other evidence it appears that the special meeting took place on the afternoon of Friday, August 8th, 1913, in the Institute of Physiology, University College. At this meeting demonstrations were given by Schäfer, Starling and others. The dinner referred to was also held, the same evening, at Pagani's Restaurant, Professor Schäfer in the chair. Most of the foreign physiologists who attended the Congress were present as guests.

The river excursion, to which allusion has already been made (p. 76), took place on the following Sunday, August 10th.

June 28th, 1913. Another meeting was held at this date at University College (instead of the usual Oxford meeting which could not be held

1 Nevertheless the members were eventually circularised on the question (pp. 151, 152). 
owing to the lamented death of Professor Gotch). Dinner was at the Grafton Hotel, Professor Starling in the chair. The following were elected members of the Society: F. R. Miller, Ff. Roberts, Douglas Cow, S. W. Patterson (London), George Graham (London), G. V. Anrep.

Dr F. R. Miller was at McGill University, Montreal. He is now Professor at the University of Western Ontario, London, Ontario.

Dr Ffrangcon Roberts was a Fellow of Clare College, and became Demonstrator in Physiology at Cambridge. He is now Radiologist to Addenbrooke's Hospital.

Dr D ouglas Cow was Assistant to Professor W. E. Dixon, Pharmacological Laboratory, Cambridge. He died in 1921.

Dr George Graham is First Assistant in the Medical Clinic at St Bartholomew's Hospital.

Dr Anrep of St Petersburg was working in the Physiological Institute of University College, where he subsequently became Assistant and Reader in Physiology. He is now a Lecturer on Physiology at Cambridge.

October 18th, 1913 (at Guy's Hospital). Dinner in the Students' Club, with Dr Pembrey in the chair.

A vote of sympathy with the family of the late Professor Gotch was proposed by Professor Bayliss, seconded by Dr Pembrey, and carried.

January 24th, 1914 (at King's College). Annual Meeting. Dinner was at the Howard Hotel, Professor Halliburton in the chair.

The Report of the Secretaries for 1913 alludes to the death of two valued members, Professor Alcock and Professor Gotch. Sixteen new members had joined the Society and the number is now 272 .

The Treasurer's Report showed a credit balance of £158. $8 s .3 d$. It was decided to invest $£ 100$ of this in Consols.

The Officers and Committee were elected, but, for the first time at an Annual Meeting, no new members were added to the Society.

The Report of the Committee on Nomenclature of the Central Nervous System was presented and adopted. The first item is as follows: "The time has not yet arrived for a general settlement of nomenclature." Certain suggestions are made in the report, but they are of no great significance and, it may be added, have not found favour with physiologists.

It was proposed by Professor Langley, on behalf of the Committee of the Society, and seconded by Dr J. S. Haldane, "that as a preliminary 
to the consideration of the question of the admission of women to the Society it is desirable to ascertain the opinion of the members on the question." This was seconded by Dr Haldane and carried with two dissentients. Professor Starling moved "that the terms of the referendum be drawn up by the Committee." This was seconded and carried.

May 16th, 1914 (at Sheffield). This was the first time the Society had met in Sheffield. Dr J. S. Macdonald was Professor of Physiology there at this time, but on Professor Sherrington's appointment to Oxford, he succeeded him at Liverpool, and his place at Sheffield was in turn taken by Professor J. B. Leathes.

June 27th, 1914 (at Oxford). Dinner in the Junior Common Room of Magdalen College, Professor Sherrington in the chair.

The following were elected members of the Society: R. A. Peters (Cambridge), J. W. C. Gunn (Edinburgh), V. Moorhouse, Joseph Merkwalder (Switzerland) and W. G. Lloyd (Leeds).

Dr R. A. Peters, O.B.E., M.C., with bar, is now Professor of Biochemistry in Oxford.

Dr J. W. C. Gunn is Professor of Pharmacology in Cape Town University.

Dr V. H. K. Moorhouse, at that time at University College, is now Professor of Physiology at Winnipeg.

Dr W. G. Lloyd was a Demonstrator of Physiology in the University of Liverpool. He was afterwards at Leeds. He died in 1925.

The result of a postcard poll with regard to the admission of women to the membership of the Society was announced as follows:

For admission on the same terms as men $\quad \ldots \quad$.. $\quad 34$

As associate members to pay reduced subscription and $\begin{array}{llllll}\text { not to attend dinners } & \ldots & \ldots & \ldots & \ldots & 36\end{array}$

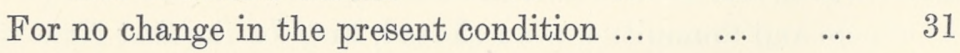

Professor C. J. Martin proposed and Professor Leathes seconded "that the Committee draw up the necessary alterations in the Rules to be proposed at the Annual General Meeting in January 1915." This was carried.

The death of Professor Hugo Kronecker of Bern, one of the Honorary Members of the Society, and the host of the International Physiological Congress of 1895, having been reported, Dr W. H. Gaskell proposed that an expression of sympathy be sent to his widow on behalf of the Society. This was carried. 
January 23rd, 1915 (at University College). Annual General Meeting. Dinner at Pagani's Restaurant, Professor Starling in the chair.

The Officers and Committee were elected and also the following new members: Henry C. Bazett (Oxford), Gordon Holmes (London), H. H. Moshier (Alberta), J. A. Murray (London).

Mr H. C. Bazett is now Professor of Physiology in the University of Pennsylvania, Philadelphia.

Dr Gordon M. Holmes, C.M.G., C.B.E., is Physician to the Royal London Ophthalmic Hospital and Assistant Physician to Charing Cross Hospital.

Dr H. H. Moshier was Professor of Physiology in the University of Alberta, Canada.

Dr James Alexander Murray (F.R.S. 1925) is Director of the Imperial Cancer Research Fund.

The Secretaries' Report for 1914 mentions the deaths of Dr. W. H. Gaskell and Professor Mines, ordinary members, and of Professor Kronecker and Professor Hermann, Honorary Members, and gives the number of ordinary members as 258 , compared with 272 at the end of the previous year.

The Treasurer's Report shows a balance of $£ 71.9 s .3 d$.

The meeting passed votes of sympathy with the families of Dr Gaskell and Professor Mines.

The following addition to the rules was carried "by a majority":

"Rule 36. Women shall be eligible for membership of the Society, and have the same rights, duties and privileges as men."

A special committee was appointed to consider the question of support to the International Catalogue, and the general question of the publication in English of reports on the progress of Physiology. The following members formed this committee: H. K. Anderson, C. S. Sherrington, W. Osler, C. J. Martin, W. L. Symes, A. D. Waller, E. H. Starling, A. R. Cushny, W. D. Halliburton, W. B. Hardy, J. Barcroft, W. M. Bayliss, J. N. Langley, E. A. Schäfer, W. M. Fletcher.

March 13th, 1915 (at King's College). Dinner in the Howard Hotel, Professor Halliburton in the chair.

A greeting from the Federation of American Societies for Experimental Biology (which was apparently sent to all the combatant nations) was read and a suitable reply returned. Both the message and the reply are entered in the Minute Book. 
A report, proposed by the special committee on Physiological Publications, relating to the International Catalogue of Scientific Papers, was read. The report states that the committee does not find that the International Catalogue has been largely used by physiologists and that the members are not agreed as to the desirability of continuing it in its present form; some members advocate separate catalogues for the different subjects at present included in the General Catalogue. The Society directed the report to be sent to the Royal Society.

An application for a contribution towards the expenses of publishing the Annual Tables of Constants was referred to the Committee.

May 15th, 1915 (at Cambridge). Dinner in St John's College, Professor Langley in the chair.

It was proposed and carried that a sum not exceeding $£ 25$ be voted to meet the expense of sending out circulars with regard to the proposed publication of abstracts of Physiological Papers. This was the beginning of the scheme for publication of Physiological Abstracts, which apparently arose out of the above suggestion, and has proved so useful to Englishspeaking physiologists.

July 3rd, 1915 (at Oxford). Dinner in Magdalen College, Professor Sherrington in the chair.

The following were elected ordinary members: Florence Buchanan (Oxford), Ruth F. Skelton, Winifred C. Cullis (London), Enid M. Tribe (London School of Medicine for Women), Constance Leetham Terry, S. C. M. Sowton, George Winfield (Cambridge), W. R. Thacker ${ }^{1}$ (Cambridge).

Six of the new members are women, who were not long in taking advantage of the alteration in the rules made in January.

Miss Winifred Cullis is now Professor of Physiology in the London School of Medicine for Women.

Miss Tribe (now Mrs Oppenheimer of New York) was Demonstrator of Physiology at the London School of Medicine for Women.

Amongst the scientific communications made at this meeting are two on the action of the poison-gases used in the War (see p. 157).

January 22nd, 1916 (at King's College). Annual General Meeting. Dinner at the Howard Hotel, Professor Halliburton in the chair.

The Secretaries' Report for 1915 shows the roll of ordinary members to stand at 260: and that one Honorary Member, Professor Ehrlich, had

1 Perhaps Dr C. R. A. Thacker. 
died during the year. Also that a new departure had been decided on in the publication of Physiological Abstracts.

The Treasurer's Report shows a credit balance of £96. 16s. $2 d$.

After election of the Officers and Committee the following new members were elected: Leslie A. T. Maxwell (Melbourne), Yas Kuno (Mukden), Lilias Charlotte Jackson (Melbourne).

At the Oxford meeting on July 15th, 1916, J. W. Trevan (St Bartholo mew's) was also elected.

Mr J. W. Trevan is Pharmacologist in the Wellcome Pharmacological Research Laboratory.

Professors Halliburton and Bayliss were nominated to represent the Society on the Conjoint Board of Scientific Studies convened by the Royal Society.

January 27th, 1917 (at King's College). Annual General Meeting. Dinner at the Howard Hotel, Professor Halliburton in the chair.

The Secretaries report that the roll of the Society at the end of 1916 was 255 , and that "the Society has suffered heavily by death, having lost three of its most distinguished ordinary members, Professor Brodie, Sir Victor Horsley and Dr Keith Lucas, and one Honorary Member, Professor Chauveau."

Votes of sympathy were passed and directed to be sent to the families of the deceased members ${ }^{1}$.

The Treasurer's Report shows a credit balance of $£ 168.13 s .4 d$. It was decided to convert the capital invested in $4 \frac{1}{2} \%$ War Bonds into $5 \%$ War Loan.

The Officers and Committee having been elected, the following new members were elected: E. D. Adrian (Cambridge), J. C. Drummond (London).

Dr Adrian (F.R.S. 1923) is now one of the Secretaries of the Society, and editor of the Proceedings. He is a Fellow of Trinity College, Cambridge, and University Lecturer in Physiology.

Dr J. C. Drummond was at the Cancer Research Institute; he is now Professor of Biochemistry at the Institute of Physiology, University College.

It was decided to ask the Royal Society to give a grant of $£ 100$ towards the expenses of publishing Physiological Abstracts: that abstractors should be paid at the rate of $2 s .6 d$. a page, that the editor should receive

${ }^{1}$ Sir Victor Horsley died of sunstróke in Mesopotamia. Dr Keith Lucas was killed flying whilst carrying out experiments on behalf of the War Office. 
the sum of $£ 20^{1}$ in recognition of his services, and that a payment of $£ 5$. $5 s$. should be made for preparation of the index.

January 26th, 1918 (at King's College). Annual General Meeting. Dinner in the Howard Hotel, Norfolk Street, Professor Halliburton in the chair.

The Secretaries' Report for 1917 alludes to the deaths of Sir Armand Ruffer, Dr Sydney Rowland ${ }^{2}$ and Mr V. W. Draper. The number of ordinary members was 251. Only five meetings were held during the year, those outside London having been given up, owing to difficulties of travelling, caused by the War.

The Treasurer's Report shows a credit balance of $£ 226.10$ s. $1 d$.

After the election of the Committee and Officers, the following new members were elected: Harriette Chick, Egerton Grey (Guy's), Elizabeth C. Eaves (Sheffield), Geoffrey Marshall (Guy's).

Dr Egerton Grey is Professor of Biochemistry in the Medical School of Cairo University.

Miss Eaves is Lecturer in Physiology in the University of Sheffield.

Dr Geoffrey Marshall, O.B.E., is Assistant Physician at Guy's Hospital: previously demonstrator of Physiology.

Three Honorary Members were elected, namely, Professor W. H. Howell (Baltimore), Professor L. Luciani (Rome), and Professor Ch. Richet (Paris) ${ }^{3}$.

The Secretary was instructed to add the date of election after the names of all the Honorary Members in the Year Book.

It was moved and seconded that the names of ordinary members of enemy nations be omitted from the list of members during the war. Eight voted for and eight against the motion: the Chairman accordingly gave his casting vote in favour of the status quo. It was also moved and resolved that the state of the Society's finances did not warrant a contribution towards the expenses of the Board of Scientific Studies ${ }^{4}$.

1 This was renewed annually.

2 Dr Sydney D. Rowland died in France in 1917 of cerebrospinal meningitis whilst serving as Major in the R.A.M.C. He was a Cambridge graduate and worked at first under Michael Foster, and afterwards in London, chiefly on enzyme action. In 1905 he went to India with the Plague Commission under Dr C. J. Martin.

3 The letters acknowledging the honour are pasted into the Minute Book.

${ }^{4}$ In view of the large credit balance (see Treasurer's Report) it is difficult to follow the reasoning of this resolution, especially as the Board was doing useful war work and the Society was represented upon it by Professors Halliburton and Bayliss. At the next Annual General Meeting the Society agreed to subscribe towards the expenses of the Board. 
A letter was read from the Board of Scientific Studies calling attention to the possibility of publication in the Society's Proceedings of matter useful to the enemy.

June 29th, 1918 (at University of London). The following new members were elected: J. Argyll Campbell (Singapore), Evelyn Hewer (London), John Boyd Orr (Aberdeen), R. H. A. Plimmer, Chas. H. Kellaway (Lister Institute).

Dr Argyll Campbell was Professor of Physiology at the Medical College of Singapore. He is now Assistant to Professor Leonard Hill, and working at the Laboratories of the Medical Research Council at Hampstead.

Miss Evelyn Hewer is Lecturer on Histology at the London School of Medicine for Women.

Dr John Boyd Orr, D.S.O., M.C., is Director of the Rowett Institute for Animal Research, Aberdeen.

Dr Kellaway is now Director of the Hall Institute for Research, Melbourne.

November 16th, 1918 (London Hospital). This was a joint meeting with the Biochemical Society. A discussion (opened by Professors Cathcart and Hopkins) took place "On the validity of the Isodynamic Law in Nutrition on the Interavailability of Fat and Carbohydrate."

January 25th, 1919 (at King's College). Annual General Meeting. Dinner at Simpson's Restaurant, Strand, Professor Halliburton in the chair.

The Secretaries' Report gives the roll of ordinary members as 257, and records the death during the year of four members, namely, Dr F. E. Batten, Dr J. Mitchell Clarke, Dr S. G. Scott, and Sir W. H. Thompson (p. 108). It also observes that, considering the difficulties of the time, the communications made at the five meetings may be regarded as satisfactory, many of these arising from investigations in connexion with war problems.

The Treasurer's Report shows a credit balance of £278. 11s. $2 d$. This includes a grant of $£ 150$ from the Royal Society to aid in meeting the expense of Physiological Abstracts (£183. 1s. 0d.). The Treasurer mentioned that many subscriptions were still owing, the debt amounting altogether to about $£ 400$. It was resolved that a letter be sent to each member in default. 
After the election of Committee and Officers, the following new members were elected: R. K. S. Lim, J. C. Meakins, C. Da Fano.

Dr R. K. S. Lim was Assistant to the Professor of Physiology, Edinburgh: he is now Professor of Physiology in the Union Medical College, Pekin.

Dr J. C. Meakins was Professor of Therapeutics in the University of Edinburgh. He is now Professor of Medicine in McGill University, Montreal.

Dr C. Da Fano was Lecturer on Histology in King's College, London. He died in March, 1927.

The Society agreed to subscribe $£ 2$. $2 s$. to the Board of Scientific Studies. It was determined to raise the price of Physiological Abstracts to £1. 10s. The Society also accepted an invitation from Professor Sir Edward Sharpey-Schafer to meet in Edinburgh at Whitsuntide.

Professor Starling stated that it had been suggested by certain French physiologists that as the institution of the International Physiological Congresses emanated from the Physiological Society, it would be appropriate that the first meeting after the War should be in this country, and that invitations should be sent to prominent physiologists (including histologists) in allied and neutral nations to come to such a congress in the ensuing summer. Professor Starling also informed the Society, with regard to the relationship of the International Research Council to the arrangements of future congresses-presumably referring to the nationality question-that the Council did not concern itself with these arrangements, but left them to the people interested. It was decided to refer the subject of a congress being held in Great Britain this summer to the Committee, which should report upon it after Professor Starling had obtained more definite information from his French colleagues.

At the meeting on March 22nd at University College Professor Starling informed the Society that he had now heard from Professor Gley that the French physiologists had decided to hold an Interallied Congress in Paris in 1920.

June 7th, 1919 (Edinburgh). The Society met on Saturday (June 7th) in the Physiology Laboratory, and the members dined, along with members of the Pathological Club, at the Caledonian Hotel, Professor Sir E. Sharpey-Schafer in the chair. Congratulations were offered to Dr Harold Pringle who had been appointed to the Chair of Physiology in Trinity College, Dublin, in succession to Sir W. H. Thompson, and to Dr John Tait, appointed to McGill University, Montreal, in 
succession to Professor Mines. Many of the members stayed in Edinburgh over the following Monday (Whit-Monday), the afternoon of which was spent at North Berwick.

July 12th, 1919 (at Oxford). Dinner at Magdalen College, Professor Sherrington in the chair.

There were no candidates for election.

Professor Halliburton informed the Society that the American Society of Biological Chemists had voted 125 dollars as a contribution towards the expenses of Physiological Abstracts, and that the American Physiological Society had also agreed to give financial support to this publication. The Secretary was instructed to convey the thanks of the Physiological Society to the two American Societies.

October 18th, 1919 (at Guy's Hospital). Dinner in the Students' Club, Dr Pembrey in the chair.

A communication having been received from Professor Arrhenius with reference to the state of poverty in which Professor Pavlov was situated in Petrograd, a sum of $£ 20$ was promised by members for transmission, if possible, to him.

January 31st, 1920 (at King's College). Annual General Meeting. Dinner in the Senior Common Room, Professor Halliburton in the chair.

The Secretaries' Report gives the number of new members during 1919 as eleven, and the number resigned as six, the total number being now 251. The deaths are mentioned of Sir William Osler and of Sir Thomas Fraser, ordinary members, and of Professors Emil Fischer, Ewald Hering and Luigi Luciani, Honorary Members. Ten meetings were held during 1919.

The Treasurer's Report shows a credit balance of $£ 279.12 s .0 d$., which is partly accounted for by the donations for Physiological Abstracts from the Royal Society ( $£ 150)$, the American Society of Biological Chemists (£29. 5s 10d.), and the American Physiological Society (£25. 13s. 4d.).

The Secretary was instructed to remove from the list of members those names whose addresses have been inaccessible for some years. The Committee ${ }^{1}$ and Officers were elected, Professor J. Mellanby becoming one of the Secretaries in place of Mr J. Barcroft, resigned. The following new members were elected: J. B. Collip (Alberta), J. A. Hewitt (St Andrews), H. L. Pierce (New York), H. W. Davies (Oxford), J. Shaw Dunn (Birmingham), Dorothy Jordan-Lloyd (Cambridge),

1 The list of Committee includes the name of Miss Winifred Cullis, the first time a woman had been a member of Committee. 
Sir Cuthbert Wallace (London), J. Barry (Cork), F. A. Duffield (Liverpool), J. Joffe (Guy's), David Burns (Glasgow), I. de Burgh Daly (University College), May L. Walker (Edinburgh).

Dr J. B. Collip is Professor of Biochemistry in Alberta University.

Mr J. A. Hewitt was Assistant to the Professor of Physiology at St Andrews. He now holds a similar position in King's College, London.

Dr H. W. Davies is now Lecturer on Biochemistry in the Department of Physiology in Leeds University. He was previously Assistant in the Biochemical Laboratory of the Royal Infirmary, Edinburgh.

Dr J. Shaw Dunn is Professor of Pathology at the University of Manchester.

Sir Cuthbert Wallace, K.C.M.G., C.B., is Professor of Surgery and Surgeon to St Thomas's Hospital.

Dr J. Barry is Professor of Physiology at Cork.

Dr F. A. Duffield is Lecturer in the Physiology Department of Liverpool University.

Dr David Burns is Professor of Physiology at Newcastle-onTyne.

Dr I. de B. Daly was Lecturer in the Institute of Physiology, Cardiff. He is now Professor of Physiology in the University of Birmingham.

Miss May L. Walker is Lecturer on Histology in the Physiology Department of Edinburgh University.

Questions relating to the Federation of Medical Societies, the cost of Physiological Abstracts, the arrangement of communications at the scientific meetings, the Physiology Section of the British Association, the supply of dyes and other chemicals were discussed and variously dealt with.

July 10th, 1920 (at the London School of Medicine for Women). Dinner in the Students' Club, Professor Winifred Cullis in the chair.

The following candidates were elected into the Society: A. N. Drury (London), Florence M. Durham (London), B. A. MeSwiney (Leeds), Swale Vincent ${ }^{1}$ (London), S. A. Kinnear Wilson (London), H. C. Broadhurst (Sheffield), G. Elliot Smith (London), J. B. S. Haldane (Oxford), W. E. Gye (London), H. B. Hickman (Bristol).

Miss Florence Durham is a worker at the National Institute for Medical Research.

1 A re-election. 
Dr B. A. McSwiney is now Professor of Physiology in Leeds.

Dr S. A. Kinnear Wils on is attached to King's College Hospital, and to the National Hospital for the Paralysed and Epileptic, Queen Square.

Dr H. C. Broadhurst was a Beit Research Fellow and Demonstrator of Physiology at Sheffield.

Mr J. B. S. Haldane, son of Dr John Scott Haldane, F.R.S., one of the senior members of the Society, is Sir William Dunn Reader in Biochemistry at Cambridge.

Dr W. E. Gye is on the Staff of the Department of Experimental Pathology in the National Institute for Medical Research, Hampstead.

Dr H. B. Hickman is Lecturer on Physiology in Bristol University.

A vote of sympathy with Professor Starling in his illness was passed, with wishes for his prompt recovery ${ }^{1}$.

November 20th, 1920 (at St Bartholomew's). This was a Special General Meeting called to effect certain alterations in the rules. By these changes, which were carried, the subscription was raised from one and a half guineas to two guineas, thirty shillings of which was to be a subscription to the Journal of Physiology: the order and duration of communications was regulated; a time limit of fifteen minutes was set for the discussion of a communication, with five minutes extra for the reply of the author; and notices of meetings were to be sent at least twenty-one days, and the programme of communications at least seven days, before the meeting.

The congratulations of the Society were sent to Professor Sherrington on the honour to Physiology and to its gifted exponent by his nomination to the Presidentship of the Royal Society; it was suggested that some form of celebration of the occasion should be arranged ${ }^{2}$.

The congratulations of the Society were also sent to Professor August Krogh of Copenhagen, the Nobel Prizeman for 1920, a member of the Society.

1 Professor Starling had recently undergone a serious operation and for some time it was thought by his medical attendants that he could not pull through. But eventually he made a complete recovery and again took a prominent part in the affairs of the Society.

A similar resolution was passed by the International (Interallied) Congress of Physiologists, which was held in Paris towards the end of this month.

${ }^{2}$ As already related (p. 81) the celebration took the form of a dinner to Sherrington at the Café Royal on March 11th, 1921, the writer being in the chair. 
January 22nd, 1921 (at King's College). Annual General Meeting. Dinner in the College, Professor Halliburton in the chair.

The Reports of the Hon. Treasurer and Secretaries were received and adopted.

The Secretaries' Report shows the number of members as 261: twentyfour new members having been elected and eleven having resigned. The death of one member, Sir Thomas Anderson Stuart, was mentioned.

The Treasurer's Report shows a credit balance of £187. 3s. $11 d$.

After election of the Committee and Officers the following candidates were admitted members of the Society: Muriel Bond (London School of Medicine for Women), J. M. H. Campbell (London), W. A. M. Smart (London Hospital), I. Feldman (London), J. H. Burn (London), Ruth Balfour (London School of Medicine for Women), A. D. Ritchie (Manchester), C. G. Imrie (Sheffield), G. A. Clark (Newcastle-on-Tyne), G. P. Crowden (London), T. H. Burlend (Cardiff), R. J. S. McDowall (Edinburgh), F. R. Fraser (St Bartholomew's), S. W. F. Underhill (St Bartholomew's), W. W. Waller (Liverpool), R. D. Passey (Guy's).

Dr J. M. H. Campbell was Demonstrator of Physiology in Guy's Hospital Medical School. He is now Assistant Physician to Guy's Hospital.

Mr W. A. M. Smart was Lecturer in Physics and Demonstrator of Physiology and is now Lecturer on Pharmacology in the London Hospital.

Mr J. H. Burn is Director of the Laboratory of the Pharmacological Society.

Dr C. G. Imrie is a Lecturer in Physiology in the University of Sheffield.

Dr G. A. Clark is Lecturer in Clinical Physiology at Newcastleon-Tyne.

Mr T. H. Burlend is Lecturer on Histology and Embryology in the Physiological Department of the School of Medicine, Cardiff.

Mr R. J. S. McDowall was Assistant in the Department of Physiology in Edinburgh; he afterwards transferred to Leeds. He is now Professor of Physiology in King's College, London, in succession to Professor Halliburton.

Dr F. R. Fraser is Professor of Medicine at St Bartholomew's Hospital and Director of the Medical Clinic.

Mr S. W. F. Underhill was Senior Demonstrator of Physiology at St Bartholomew's Hospital Medical College. He now holds an 
appointment in the Physiological Laboratory of "British Drug Houses."

Mr William Walls Waller, son of Augustus Désiré Waller and grandson of Augustus Waller, the discoverer of Wallerian degeneration, is Demonstrator of Physiology in Liverpool.

Dr R. D. Passey, M.C., was Senior Demonstrator of Pathology in Guy's Hospital Medical School. He is now Professor of Experimental Pathology and Director of Cancer Research in the University of Leeds.

A provisional list of twelve places of meeting for 1921 was announced. One meeting was to be at Aberdeen and one at Edinburgh, but neither seems to have been held.

A resolution was adopted deprecating the closure of the Physiological Laboratory of the University of London at South Kensington as liable to cause grave injury to the advancement of the science and teaching of Physiology and contrary to the public interest.

This resolution was forwarded to the Academic Registrar of the University and to the London County Council which had subsidised the undertaking, but it failed to prevent the threatened closure of the Laboratory being carried out. Before the closure had taken place Dr Waller, who had been from the first the Director of the Laboratory, had died (p. 166).

Letters from Professor Arrhenius and Mr Maxim Gorki were read showing that the fund subscribed for Professor Pavlov had been conveyed to him, and that he was able to do a certain amount of work although suffering from insufficiency of food.

March 12th, 1921 (at University College). Dinner at the Grafton Hotel, Professor Starling in the chair.

The Chairman reported that the Committee had decided to abolish temporarily the publication of the Proceedings and to increase the subscription price of Physiological Abstracts to two guineas, this being necessary on account of the great increase in cost of production. The action of the Committee was approved.

July 9th, 1921 (at Oxford). Dinner in Christ Church, Professor Sherrington in the chair.

The following candidates were admitted to the Society: Charles Walker (Liverpool), R. K. Cameron (University College), H. G. Earle 
(Hong Kong), E. Lüscher (Bern), E. W. H. Cruickshank (Peking), V. H. K. Moorhouse (Winnipeg), W. E. L. Brown (Manchester), E. C. Dodds (Middlesex Hospital), J. S. B. Stopford (Manchester), Ardrey W. Downs (Alberta), E. H. G. Williams (London), H. W. C. Vines (Cambridge), G. S. Adair (Cambridge), E. Overton (Lund), B. R. G. Russell, W. R. Fearon (Dublin), R. McCarrison (India), F. M. R. Walshe (London), G. de Decker (Belgium), C. G. Lambie (Edinburgh), J. M. Watt (Johannesburg), E. Brice Mayrs (Belfast), Helene Connet.

Dr C. E. Walker is Professor of Cytology and Lecturer on Histology in the University of Liverpool.

Dr H. G. Earle is Professor of Physiology in Hong Kong University.

Dr E. W. H. Cruickshank was Professor of Physiology in the Union Medical College, Peking. He is now at Patna.

Dr V. H. K. Moorhouse was elected a member in 1914 (p. 152). This is therefore a re-election.

Mr W. E. L. Brown of Trinity College, Cambridge, was at this time working with Professor A. V. Hill in Manchester. He is now in Cambridge.

Dr E. C. Dodds is Professor of Biochemistry and Chemical Pathology in Middlesex Hospital Medical School.

Dr J. S. B. Stopford (F.R.S. 1927) is Professor of Anatomy in Victoria University, Manchester.

Dr Ardrey W. Downs is Professor of Physiology in the University of Alberta, Edmonton.

Dr H. W. C. Vines is a Fellow of Christ's College, Cambridge, and was Foulerton Research Student of the Royal Society.

Dr E. Overton is Professor of Physiology in the University of Lund, Sweden.

Lt.-Col. R. McCarrison, C.I.E., is Director of the Pasteur Institute of Southern India.

Dr F. M. R. Walshe is Neurologist to the Medical Unit, University College Hospital, and Physician to the National Hospital for the Paralysed and Epileptic, Queen Square.

Miss G. de Decker was Professor Waller's Assistant in the University of London Laboratory of Physiology.

Dr C. G. Lambie was Assistant to the Professor of Pharmacology, Edinburgh.

Dr J. M. Watt is Professor of Pharmacology in the University of Witwatersrand. 
A vote of sympathy with Mrs and Miss Menzies on the death of Professor Menzies was passed.

November 19th, 1921 (at St Thomas' Hospital). This was a Special General Meeting to consider proposed changes in the rules. Professor Langley was in the chair. The principal changes recommended by the Committee provided for the payment of the cost of the Proceedings by the author of each communication, the payment being at the rate of $£ 1$ per page in addition to the cost of blocks, and that the provision of abstracts for the use of members at the meetings should not be continued. These alterations were agreed to ${ }^{1}$.

The Special Meeting was followed by an ordinary meeting at which Professor J. Mellanby took the chair.

A vote of sympathy with Mrs Bainbridge on the regretted death of her husband was adopted.

January 21st, 1922 (at King's College). Annual General Meeting. Dinner at the College, Professor Halliburton in the chair.

The Secretaries' Report for the year 1921 shows thirty-nine new members elected, while eight have been lost by death or resignation. The roll now stands at 293.

The deaths of Professor Menzies, Professor Bainbridge, Professor Sir G. Sims Woodhead, and Dr Gustav Mann are recorded. Allusion is made to the congratulatory dinner to Sir Charles Sherrington (p. 161) which was held in March.

The Treasurer's Report shows a credit balance of $£ 425$. 12s. 10d., but it has been increased by the sale of Stock (£246. $9 s$. 10d.) as well as by the donations from the Royal Society and the American Societies of Biological Chemists and of Physiology.

It was decided that copies of the Balance Sheet should be distributed in future before the Annual General Meeting.

The Secretary announced that arrangements had been made with Messrs Lewis to print the List of Members free of expense on consideration of the insertion of advertisements to be approved by the Society.

The Officers and Committee having been elected, the following candidates were admitted to the Society: Trevor B. Heaton (Oxford), H. St A. Heathcote (Cairo), A. Hassan (Cairo), Eric Ponder (Edinburgh), J. R. Hay-Mouatt, G. M. Wishart (Glasgow), A. J. Huggett² (St Thomas's),

1 In consequence of these changes the publication of the Proceedings, which had been suspended since the meeting of March 12th, was resumed.

2 Should be A. St G. H. M. Huggett. 
E. Wace Carlier (Birmingham), J. C. Bramwell (Manchester), E. B. Verney (University College), Ellen Boock (London), Gladys Hartwell (King's College for Women, London), J. W. Pickering (King's College), R. A. Rowlands (London Hospital), E. G. T. Liddell (Oxford).

Dr T. B. Heaton is Lees Reader in Anatomy, Oxford.

Dr H. St A. Heathcote is Professor of Pharmacology at Cairo.

Dr Eric Ponder was Lecturer on Biophysics in the Physiology Department of Edinburgh University. He is now Associate Professor of General Physiology in New York University.

Dr Huggett is Demonstrator of Physiology in St Thomas's Hospital Medical School.

Dr E. Wace Carlier was Professor of Physiology at Birmingham. He has now retired and is succeeded by Dr Daly.

Dr J. C. Bramwell is Physician in the Royal Infirmary, Manchester.

Mr E. B. Verney was Assistant in the Department of Physiology in University College, London. He is now Professor of Pharmacology in University College.

Dr R. A. Rowlands was Demonstrator of Physiology in the London Hospital Medical School, and is now Assistant Physician to the Hospital.

Mr Liddell is a Fellow of Trinity College, Oxford, and Demonstrator of Physiology.

A vote of congratulation to Sir Charles Sherrington on his receiving the Grand Cross of the British Empire was adopted ${ }^{1}$.

The attention of members was directed to the appeal being made for subscriptions to the memorial to the late Professor Chauveau, one of the Society's Honorary Members.

March 18th, 1922 (at University College). Professor Starling in the chair.

The Secretary was directed to send an expression of sympathy to Mrs Waller and to the family of Professor Moore, on the regretted deaths of Professor Waller and Professor Moore.

July 8th, 1922 (at Oxford). Dinner in St John's College, Professor Sir Charles Sherrington in the chair.

The following candidates were admitted to the Society: S. J. Covell (Sheffield), Norman M. Dott (Edinburgh), Henry Dryerre (Edinburgh),

1 Sir Charles Sherrington's letter of thanks is preserved in the Minute Book. 
Lady Briscoe (London), H. D. Kay (Cambridge), Catherine Coward (London), Nicholas B. Dreyer (Halifax, Nova Scotia), F. J. W. Roughton (Cambridge), O. Inchley (London), J. H. Crawford (New York).

Mr Norman M. Dott was Assistant to the Professor of Physiology, Edinburgh; he is now Surgeon to Chalmers Hospital and to the Deaconess Hospital, Edinburgh.

Dr Henry Dryerre is Professor of Physiology in the Royal Dick Veterinary College, Edinburgh, and Lecturer in Physiology and Biochemistry in the University of Edinburgh.

Lady G. M. Briscoe was Pathologist under the Medical Research Council and Assistant in Applied Physiology at the Flying Hospital, Hampstead.

The following changes in the Officers of the Society were made: Professor W. M. Bayliss to be Honorary Treasurer, Professor J. Mellanby to be Senior Honorary Secretary, Dr E. D. Adrian to be Junior Honorary Secretary and editor of the Proceedings.

Votes of thanks to Professor Bayliss for his services as Honorary Secretary, and to Mr W. L. Symes for his valuable assistance during several years in connexion with the Treasurer's accounts were adopted.

July 27th, 1922 (at Glasgow). This was a combined meeting of the Society and the Physiological Section of the British Medical Association, which was meeting in Glasgow.

November 18th, 1922 (at Manchester). Dinner in the Refectory of the University, Professor A. V. Hill in the chair.

The Secretary communicated an invitation from the Medical Section of the Royal Society of Medicine to a discussion of "Life at High Altitudes" on December 15th. The invitation was ordered to be printed on the programme of the next meeting of the Society.

December 16th, 1922 (at the National Institute for Medical Research).

Professor Cushny drew the attention of the meeting to the question as to whom notices of the approaching meeting of the International Physiological Congress, to be held in Edinburgh, should be sent. The meeting was unanimously of opinion that the issue of these notices should be universal, and that no countries should be debarred from receiving them ${ }^{1}$.

1 This opinion was acted on. A similar expression of opinion was received from the American Physiological Society. 
January 20th, 1923 (at King's College). Annual General Meeting. Dinner at the Norfolk Hotel, Professor Starling in the chair (in the absence of Professor Halliburton on account of illness).

The Secretaries' Report for 1922 states that twenty-five members have been elected and six have resigned, bringing the roll to 309. The deaths of three prominent members are referred to, namely, Professors Haycraft, Moore and Waller.

The Secretary was directed to convey to Professor Halliburton the greetings of the Society and a hope for his speedy return to health. Also to convey to the family of the late Professor J. B. Haycraft the sympathy of the Society.

The resignation of Professor Halliburton from the editorship of Physiological Abstracts was announced, and the Secretary was directed to convey to him the regret of the Society that he had felt compelled to take this step, and its hearty thanks for his labours, which had made the publication so conspicuous a success. It was remitted to the Committee to consider and report on the future conduct of the publication.

The Society voted the usual honorarium of $£ 20$ to Professor Halliburton for his services as editor during the past year, and an honorarium of $£ 50$ to the assistant editor, Mr C. L. Evans. The Officers and Committee were then elected and the following candidates were admitted members of the Society: S. W. Hardikar (India), C. R. Harington (London), G. E. Gask (London), W. F. Shanks (Leeds), Samson Wright (London), N. Morris (Glasgow), K. J. Franklin (Oxford), H. M. MacKeith (Oxford), John Pryde (Cardiff), T. P. Dunhill (London), Hartley Lupton, E. M. Watson (Canada), W. O. Fenn (Rochester, N.Y.), S. Babkin (Halifax, N.S.), E. C. Warner (London), Ruth E. Conway (London), G. A. Harrison (London).

Mr C. R. Harington is Biochemist at University College Hospital Medical School.

Mr G. E. Gask, C.M.G., D.S.O., is Professor of Surgery in St Bartholomew's Hospital and Director of the Surgical Unit.

Mr Samson Wright was Senior Demonstrator of Physiology at the Middlesex Hospital Medical School.

Dr Noah Morris is Professor of Physiology in Anderson College, Glasgow.

Mr John Pryde is Assistant in Biochemistry in University College, Cardiff.

Mr T. P. Dunhill, C.M.G., is Assistant Director of the Surgical Unit in St Bartholomew's Hospital. 
Dr Babkin is Professor of Physiology in Dalhousie University, Halifax, N.S.

Mr G. A. Harrison is Lecturer on Biochemistry at St Bartholomew's Hospital Medical School.

March 17th, 1923 (at University College). Dinner at the University of London Club, Professor Starling in the chair.

The following arrangements were announced regarding the conduct of Physiological Abstracts: Sir William Bayliss to be editor in chief; Drs J. H. Burn, J. A. Hewitt, D. T. Harris, W. Styles and E. H. J. Schuster to be sub-editors (Dr Schuster, press-editor). Each sub-editor to be paid $£ 50$ per annum. Each abstractor to receive $2 s .6 d$. per page plus a proportionate share of any profits which might result from the sale of the publication.

Walter Styles, D.Sc., Cambridge, is Professor of Botany in the University of Reading: E. H. J. Schuster is on the Staff of the National Institute for Medical Research, Hampstead. Neither are members of the Society.

July 7th, 1923 (at Oxford). Dinner in Trinity College, Sir Charles Sherrington in the chair.

The following candidates were admitted members of the Society: F. A. E. Crew (Edinburgh), L. T. Hogben (Edinburgh), R. Hilton (St Bartholomew's), Thos. Lumsden (Lister Institute), W. K. Slater (London), T. H. Oliver (Manchester), E. K. Marshall, Jr. (Baltimore, Md., U.S.A.), Louis Gross (New York), Miss M. O. P. Wiltshire (Vassar College, N.Y., U.S.A.), S. S. Zilva (Lister Institute), L. E. Bayliss (London).

Dr F. A. E. Crew is Director of the Animal Breeding Research Department, University, Edinburgh.

Dr L. T. Hogben was successively Lecturer in the Departments of Animal Breeding and of Physiology in Edinburgh University. He afterwards became Associate Professor in the Department of Zoology in McGill University, Montreal, and is now Professor of Natural History in the University of Cape Town.

Dr R. Hilton is Assistant in the Medical Unit, St Bartholomew's Hospital.

Dr T. H. Oliver is Assistant Physician to the Royal Infirmary, Manchester.

Dr E. K. Marshall, Jr., is Professor of Physiology in Johns Hopkins University, Baltimore. 
Mr L. E. Bayliss, son of Professor Sir W. M. Bayliss, F.R.S., is an Assistant in the Department of Physiology of University College.

July 23rd to 27th, 1923 (at Edinburgh). This was the occasion of the holding of the Eleventh International Physiological Congress, of which Professor Sir Edward Sharpey-Schafer was President. Many members of the Society attended the Congress and communicated papers to its Proceedings. These were published in the Quarterly Journal of Experimental Physiology, Supplementary Volume, 1923.

January 19th, 1924 (at University College). Annual General Meeting. Dinner at the College Refectory, Professor A. V. Hill in the chair.

The Secretaries' Report for 1923 shows twenty-eight new members elected and three resigned: the number being now 334 . There were eight meetings with thirty-eight demonstrations and ninety-eight other communications, but some of the latter were crowded out; the average number per meeting was nine, allowing rather more than fifteen minutes for each. Attention is drawn in the Report to the high cost to individual members of publishing their communications in the Proceedings.

The Committee and Officers having been elected, the names of three foreign physiologists were added to the list of Honorary Members, viz. Professor W. Einthoven (Leiden), Professor E. Gley (Paris) and Professor Graham Lusk (New York).

The following candidates were admitted as ordinary members of the Society: L. B. Winter (Cambridge), W. Smith (Cambridge), S. A. Asdell (Cambridge), J. Gray (Cambridge), J. M. Duncan Scott (St Bartholomew's), Sybil Cooper (Oxford), J. Needham (Cambridge), P. C. Raiment (Oxford), G. L. Peskett (Oxford), John Fulton (Brookline, Mass., U.S.A.), F. G. Banting (Toronto), H. S. Gasser (St Louis, Mo., U.S.A.), Sylvia K. Hickson (Manchester), Gladys Kay (London), J. W. McNee (London), C. A. Botwood (Leeds).

Mr James Gray, M.C., is a Fellow of King's College, Cambridge, and University Demonstrator in Comparative Anatomy.

Dr Duncan Scott was Demonstrator of Physiology in St Bartholomew's Medical School. He is now Professor of Physiology in the University of Saskatchewan, Saskatoon.

Mr J. Needham is Assistant in the Biochemical Laboratory, Cambridge.

Mr P. C. Raiment is Demonstrator of Biochemistry in Oxford. 
Dr F. G. Banting is Professor of Experimental Medicine in Toronto. He was awarded a Nobel Prize for Medicine in 1923.

Mr J. W. McNee, D.S.O., is Assistant in the Medical Unit, University College Hospital.

Mr John Fulton was working at this time in the Oxford Laboratory with Sherrington. He was at one time Instructor in Physiology at Harvard.

Sir Walter Fletcher proposed and Dr C. J. Martin seconded a resolution of congratulation and good wishes to those members of the Society who had lately received the Nobel Prize. The resolution having been adopted, Professor A. V. Hill returned thanks to the meeting on his own behalf.

It was referred to the Committee to consider whether the Annual Meeting should be held in March so as to allow more time for the Treasurer's Balance Sheet for the year to be drawn up. It was also referred to the Committee to consider whether the allocation of work to the different abstractors might be improved upon.

March 15th, 1924 (at St Bartholomew's). Dinner in the Manchester Hotel, Professor C. Lovatt Evans in the chair.

This was a Special Meeting called to consider alterations in the rules. The Committee recommended that the Annual General Meeting should in future be held in March and the Half-yearly Meeting for election of new members in October: the recommendation was adopted.

The advisability of discontinuing the publication of Physiological Abstracts after March 1925 was brought up and after discussion the meeting adopted a resolution that it should be continued: the ways and means being deferred for consideration to a subsequent meeting.

May 24th, 1924 (at Cambridge). Dinner in Trinity College, Professor Langley in the chair.

Physiological Abstracts. The Committee proposed that Professor J. Mellanby should be appointed general editor in place of Professor Sir William Bayliss (who had resigned on account of illness), and that the assistant editors (p. 169) should be re-appointed. These proposals were adopted, as was a further proposal that abstractors should be paid at the rate of one shilling per inch of printed matter.

The question of holding a meeting in Leiden in April 1925 was considered, and as a result of the discussion it appeared that if an invitation were received by the Society many members would attend the meeting.

The proposal of the American Biological Societies to publish a Journal 
containing abstracts of papers bearing on all biological subjects was explained by Professor Starling, who stated that the Committee of the Society had appointed representatives to meet the American representatives to discuss the relation of the proposed new publication to Physiological Abstracts.

July 5th, 1924 (at Oxford). Dinner in Magdalen College, Professor Sir Charles Sherrington in the chair.

The Chairman extended a special welcome to Professor Graham Lusk, one of the new Honorary Members.

On the motion of Dr H. H. Dale the congratulations of the Society were tendered to Sir Charles Sherrington on his having had the Order of Merit conferred upon him.

The following candidates were admitted to the Society: A. S. Parkes (University College), E. J. Warburg (Copenhagen), D. F. L. Golla (Maudsley Hospital), F. C. Smith (London Hospital), H. M. Carleton (Oxford), R. Azuma (Tokyo), T. Secker (Newcastle-on-Tyne), Eleanor M. Scarborough (London School of Medicine for Women), J. F. Donegan (Galway), J. Frost (Madras), H. H. Woollard (London), R. Coope (Liverpool), G. B. Fleming (Glasgow), R. Robison (Lister Institute, London), H. T. Channon (University College, London), J. M. O'Connor (Dublin), C. F. A. Pantin (Plymouth), C. N. H. Long (Montreal), Basiswar Sen (Calcutta), J. G. Dusser de Barenne (Utrecht), H. Goldblatt (Cleveland, Ohio), G. Marshall Findlay (London), H. S. H. Wardlaw (Sydney), J. C. Spence, M.C. (Newcastle-on-Tyne), E. J. Conway (Dublin), H. G. Reeves (King's College, London).

Dr H. M. Carleton is Lecturer on Histology in the Physiology Department of the University of Oxford.

Miss E. M. Scarborough is Reader in Pharmacology in the London School of Medicine for Women.

Dr J. F. Donegan is Professor of Physiology in University College, Galway.

Dr R. Coope is Lecturer on Biochemistry in the University of Liverpool.

Dr J. M. O'Connor is Professor of Physiology in University College, Dublin.

October 18th, 1924 (at Guy's Hospital). Dinner in the Students' Club, Professor Pembrey in the chair.

A vote of condolence with Lady Bayliss on the death of her husband was passed and the Secretary was directed to write to Lady Bayliss 
expressing the great loss the Society had suffered and the sympathy of the Society in her bereavement.

The nomination of Professor Pembrey by the Committee as Acting Treasurer was approved.

Dr Dale gave an account of the meeting at Toronto of representatives of the Society with the American Committee of the proposed Biological Abstracts. The Society approved of the nomination of Professor Bazett to represent the Society in America in connexion with that publication.

January 17th, 1925 (at St Thomas's Hospital). Dinner in the Students' Club, Dr V. J. Woolley in the chair.

An invitation from Professor Einthoven to the Society to meet at Leiden on Saturday, April 4th, 1925, was read. Members wishing to attend were asked to send their names to Professor J. Mellanby.

The following resolution proposed by the Committee regarding the American scheme for publication of Biological Abstracts was adopted by the Society: "The Society is of opinion that the projected American publication will not replace effectively Physiological Abstracts and that it would not be in the interests of Physiology in this country to discontinue the publication of Physiological Abstracts."

March 21st, 1925 (at University College). Annual General Meeting. Dinner at Pagani's Restaurant, Professor A. V. Hill in the chair.

The Officers and Committee for the ensuing year were elected, Professor M. S. Pembrey being chosen as Honorary Treasurer in the place of the late Sir William Bayliss, and Professor H. E. Roaf and Dr E. D. Adrian being elected Honorary Secretaries.

The Secretaries' Report for the year 1924-25 shows that forty-two members have been elected, eleven have resigned and five have died. There are now 350 members. Eleven meetings were held of which eight were in London. Altogether there were sixty-three demonstrations and ninety-five oral communications - an average of six and nine respectively per meeting. Some of the meetings were so largely attended that members had difficulty in seeing the demonstrations, and if the numbers continue to grow at the present rate only the largest Physiological Laboratories will be able to hold the meetings.

The Treasurer's Report was received and adopted. It shows a credit balance of $£ 156$. 9 s. $11 d$., and a sum of $£ 900$ placed on deposit. (The Report is now printed and issued each year with the list of members.)

It was proposed by Professor Starling and seconded by Professor Sharpey-Schafer that the Committee be asked to reconsider the cost of publication in the Proceedings, and to consider the proposals that proofs 
of the papers be again available for perusal at the meetings at which the papers are to be read. This was agreed to.

Professor Starling reported that the Twelfth International Congress of Physiology is to be held in Stockholm August 3rd to 6th, 1926.

Professor Sharpey-Schafer moved and Dr Adrian seconded a resolution "that in view of the fact that the Society was founded in 1876 the Committee be asked to consider in what form the Society shall celebrate its Fiftieth Anniversary." This was agreed to.

Professor Pembrey moved and Dr Adrian seconded a resolution that "Sir E. Sharpey-Schafer be asked to write a report on the foundation of the Society." This was agreed to.

Various emendations in the rules were agreed to, amongst these being that the editor of Physiological Abstracts should ex officio be a member of the Committee of the Society.

The following candidates were admitted members of the Society: G. Spencer Melvin (Kingston, Ontario), E. Walker (Oxford), F. R. Winton (London), Fritz Eichholtz (Freiburg i/Br.), Adrian Stokes (Guy's), E. N. Wilmer (Manchester), J. C. Waller (Liverpool), Phyllis M. Kerridge (University College), Norman Burgess (Guy's), Margaret Murray (London), J. H. Shaxby (Cardiff), K. Shirley Smith (London), Owen S. Gibbs (Halifax, N.S.), A. W. M. Ellis (London Hospital), Raymond Whitehead (Manchester), H. E. Magee (Aberdeen), Louis N. Katz (Cleveland, Ohio), W. W. Payne (Guy's), Helena Wastl (Vienna), K. H. Tallerman (Cambridge).

Dr G. Spencer Melvin is Professor of Physiology in Queen's University, Kingston, Ontario.

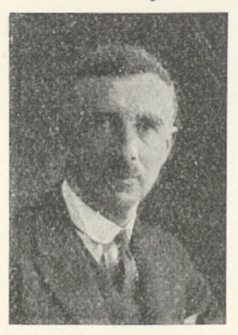

Dr Adrian Stokes was Professor of Pathology at first at Trinity College, Dublin, and afterwards in Guy's Hospital Medical School. He died on September 19th, 1927, at Lagos from yellow fever, the cause of which he was engaged in investigating for the Rockefeller Commission. He was "one of the most brilliant students of medicine of this generation." An account of his career is given in the British Medical Journal for Oct. 1, 1927.

Mr J. C. Waller, the youngest son of the late Professor A. D. Waller, is an Assistant in the Botanical Department of the University of Liverpool.

Mrs Kerridge is Assistant in the Physiology Department and Instructor in Physical Chemistry in University College, London. 
Dr J. H. Shaxby is Lecturer in Physics in University College, Cardiff.

Dr A. W. M. Ellis is Director of the Medical Unit and Professor of Medicine, London Hospital.

$\mathrm{Mr} \mathrm{H}$. E. Mage e is Physiologist at the Rowett Research Institute, Aberdeen.

Mr W. W. Payne was Demonstrator of Physiology at Guy's Hospital Medical School. He is now Biochemist at the Hospital for Sick Children, Great Ormond Street, London.

April 4th, 1925 (at Leiden, Holland). A scientific meeting was held in the Pharmaco-Therapeutical Institute at 10 a.m. and in the Physiological Laboratory at 11 a.m. At 2.30 p.m. another session was held in the Physiological Laboratory.

After the scientific meeting the members of the Physiological Society were invited by their Dutch colleagues to a banquet, at which Professor Einthoven presided. Eighty-five persons were present at the dinner and signed their names.

As this was a historic occasion, being the first meeting of the Society which has been held outside Great Britain, the signatures are here reproduced, and may serve for comparison with the facsimile of the signatures of the twenty-two members who attended the inaugural dinner of the Society in May, 1876 (p. 14).

On Sunday, April 5th, the members and their friends were invited to view the bulb-fields and to visit the International Floral Exhibition at Heemsted. After lunch, which was provided at Heemsted, the party visited the Franz Hals Museum at Haarlem, where they were kindly shown over by the Director of the Museum.

On Monday, April 6th, the members and their friends were invited to the Laboratories of Physiology, Pharmacology and Biochemistry at Utrecht, where a number of interesting demonstrations and communications were made by workers in those laboratories.

Titles and short descriptions of the communications are entered in the Minute Book of the Society.

May 23rd, 1925 (at Cambridge). After the scientific meeting in the Physiological Laboratory at which seven demonstrations and sixteen oral communications were made, the dinner meeting was held in Trinity College, with Professor J. N. Langley in the chair. 
The Society expressed approval of the action of the Committee in instructing the Secretary to write a letter to Professors Einthoven, Magnus, Zwaardemaker, and Storm van Leeuwen and their colleagues, thanking them for their hospitality during the Society's visit to Holland ${ }^{1}$.

May 30th, 1925 (at Edinburgh). The scientific meeting was held in the Physiological Laboratory in the morning from 9.30 to 12.30. There were thirteen demonstrations and twelve oral communications. After lunch the members took train to North Berwick, with the object of visiting the Bass Rock, but the weather was such that landing on the island was impossible, so the party dispersed in various directions, some driving to Tantallon Castle, others ascending North Berwick Law, and others playing golf. All met for tea at Park End. After tea the members of the Society travelled to Edinburgh and dined at the North British Station Hotel, Professor Sir E. Sharpey-Schafer in the chair. Amongst the guests were Dr and Mrs Scott, of the City of New York College; Dr and Mrs Thorne Carpenter, of the Carnegie Nutrition Laboratory, Boston; and Professor Jarisch, of Innsbrück.

October 17th, 1925 (at Guy's Hospital). Dinner in the Students' Club, Professor M. S. Pembrey in the chair.

The Chairman announced that the laboratory of origin of papers in the proceedings of the Society can now be stated.

This needs explaining. When the Proceedings were first published in the Journal of Physiology, the laboratory in which the work was done was almost invariably that in which the meeting was held, since the original object of the scientific meetings was to exhibit to other members of the Society work which was actually in progress, and it was not necessary to announce that the work was done in that laboratory. But soon workers from other laboratories got in the habit of bringing their work to the institutions where it was customary to hold the scientific meetings. Nevertheless-although there was no rule to the contrary - the place where this work was being done was not specifically mentioned in the Proceedings, although the members of the Society were themselves aware of it. This was misleading for those readers of the Proceedings who did not belong to the Society. Nevertheless the custom of withholding the information as to the laboratory where the work was done was adhered to, although there was neither rhyme nor reason in its favour. It is now announced that the custom is abolished.

1 The deaths of Professor Magnus (August 1927) and Professor Einthoven (September 1927), have occurred whilst this sheet was passing through the press. 
The following candidates were admitted to the Society: K. Furusawa (Japan), H. P. Gilding (St Bartholomew's), R. D. Lawrence (King's College Hospital), Henrietta Bainbridge (Wellcome Laboratory, Beckenham), R. Garry (Glasgow), H. Florey (London Hospital), W. D. Forrest (London Hospital), R. J. Lythgoe (London), G. P. Wright (St Louis, U.S.A.), H. N. Segall (Outremont, Canada), G. Liljestrand (Stockholm), H. C. Ellis Wilson (Glasgow), A. J. Copeland (Cambridge), A. Hemmingway (King's College), R. J. Brocklehurst (St Bartholomew's), T. H. Gaddum (London), R. Kinosita (Japan), H. S. D. Garwen, A. Watson (Glasgow), H. Cohen (Liverpool).

It was resolved, on the motion of Professor Graham Brown, seconded by Professor Swale Vincent, that an invitation to attend the meeting to be held at Cardiff in November be extended to Sir William James Thomas, who had presented the Physiological Laboratory to the University of Wales.

November 14th, 1925 (at Cardiff). Dinner in the Royal Hotel, Professor T. Graham Brown in the chair.

The death of Professor J. N. Langley, an original member of the Society, was reported. A vote of condolence to Mrs Langley was passed, the members upstanding. The Secretary was directed to write to Mrs Langley expressing the great loss the Society had suffered by her husband's death and the sympathy of the Society in her bereavement. Mrs Langley's reply in acknowledgment of this message is preserved in the Minute Book.

\section{Acquisition of the Journal of Physiology by the Society.}

Consequent on Professor Langley's death the question of the acquisition of the Journal of Physiology by the Society became urgent, and the Committee entered into negotiations with his executors with the view of the publication being taken over by the Society. In order to give the Committee the necessary authority a special general meeting was called on December 12th, 1925, to deal with the matter.

At this meeting, which was held at Bedford College, with Professor J. S. Edkins in the chair, Professor Starling proposed on behalf of the Committee the following recommendations: these were unanimously agreed to:

1. That the Committee be authorised to suspend all rules of the Society relating to the Journal and to the publication of the Proceedings at their discretion. $\mathrm{PH}$. 
2. That Messrs Clay (the printers) be informed that, failing the conclusion of an agreement between the Society and the executors of the late Professor Langley, all arrangements with regard to the Journal and to the publication of the Proceedings lapse as from 31st December, 1925, and that the Society will not be responsible for any copies of the Journal sent to members of the Society after that date.

3. That the Editor of the Proceedings be empowered to suspend their publication until further notice.

4. That the Committee be authorised to offer the sum of $£ 1000$, payable in four annual instalments free of interest, to the executors of the late Professor Langley for the whole of his interest in the Journal of Physiology. Back numbers up to the end of Volume 60 are not included and will remain the property of Professor Langley's representatives, who will also be entitled for ten years to a quarterpage free advertisement of the said back numbers in each number of the Journal.

Following the Special General Meeting an ordinary meeting for scientific communications was held. Mrs Langley's letter of thanks for the Society's letter of condolence (p. 177) was read, and also a letter from Professor Hans Meyer, one of the Honorary Members of the Society, as President of the Wiener biologische Gesellschaft, condoling with the Society on the loss it had sustained by Professor Langley's death.

It was agreed on the recommendation of the Committee that Dr Henry Head be elected an Honorary Member.

The scientific programme was then proceeded with.

January 23rd, 1926 (at the National Institute for Medical Research). Dinner at the Euston Hotel, Dr H. H. Dale in the chair.

Professor Cushny and Dr Dixon were appointed to represent the Society at the Conference on revision of the British Pharmacopœia.

Two members were removed from membership of the Society, since they had not replied to applications for their subscriptions sent by registered post.

The Secretary was instructed to write letters of condolence to the relatives of the late Professor J. G. McKendrick and the late Dr Richard Caton expressing the sense of the Society of the value of their work for the science of Physiology.

The Secretary was instructed to send a letter to Mrs Langley expressing their appreciation of the work of the late Professor Langley for the 
Journal of Physiology and the intention of the Society to maintain the high level of the Journal' .

A letter from Dr Head was read expressing appreciation of his election as Honorary Member.

The following recommendations of the Committee regarding the administration of the Journal of Physiology were agreed to:

1. There is to be an Editorial Board of four Editors, one of whom is to be permanent Chairman of the Board.

2. One of the Editors is to be named to whom all papers should be sent in the first instance.

3. The Editor who receives the papers shall be provided with paid clerical assistance.

4. The Editors to have occasional meetings, the fares to be paid out of Journal funds.

5. Until the Society otherwise determines, not more than two volumes of approximately six hundred pages each shall be published per annum.

6. The Editors to have complete discretion.

7. The Board of Editors to report to the Committee any suggestions they wish to make as to the conduct of the Journal, and to consult with the Treasurer as to financial arrangements.

It was further agreed that Sir Charles Sherrington be invited to act as Chairman of the Editorial Board, and that Dr E. D. Adrian, Professor A. V. Hill and Professor J. B. Leathes be the other three editors: that the Treasurer, Secretaries and Chairman of Committee be appointed Trustees for the purchase of the Journal of Physiology: and that the Treasurer be authorised to transfer $£ 750$ to the Trustees of the Journal for a special publication fund.

February 20th, 1926 (at King's College). Dinner in the Senior Common Room, Professor R. J. S. McDowall in the chair.

Letters were read from Miss Caton, Dr J. Soutar McKendrick and Mrs Langley in reply to the letters which had been sent to them on behalf of the Society.

March 20th, 1926 (at University College). Annual General Meeting. Dinner in the Refectory of the Medical School, Professor E. H. Starling in the chair.

The meeting - the members upstanding-passed votes of condolence with the relatives of the late Professor A. R. Cushny and the late Pro1 The draft of the letter is preserved in the Minute Book. 
fessor Sutherland Simpson; the Secretary was instructed to write letters conveying the sympathy of the Society to their relatives.

The Report of the Secretaries shows that during the year 1925 forty ordinary members had been elected, nine had resigned, the names of two had been removed under Rule 17, and six had died.

The names of those who had died are Dr J. Graham Brown, Professor Arthur R. Cushny, Professor John Newport Langley, Sir James Mackenzie, Professor J. G. McKendrick and Professor Sutherland Simpson. The Secretaries add: "It is a striking fact that all these were men of distinction and most of them had been members of the Society for many years." The Secretaries reported that a distinguished former member, Dr Richard Caton of Liverpool, who was an original member of the Society, but had resigned membership on account of advancing age, had also died during the year.

The total number of ordinary members is now 377. One Honorary Member has been elected, bringing the number of Honorary Members up to eight. The date of election of each member is in future to be placed after his name in the printed list of members.

There had been eleven ordinary meetings and one special general meeting. The meeting of the Society at Leiden and the visit to Utrecht are also referred to.

The average number of demonstrations at each meeting was nine, and of oral communications twelve.

The acquisition of the Journal of Physiology by the Society is referred to in the Report, as well as the necessary revision of the Rules consequent on this step. The Report concludes: "This year the Society will complete the fiftieth year since its foundation, and it is probable that some steps will be taken to commemorate this fact."

The rules of the Society as amended were passed for printing in the Annual List of Members. It was suggested by the Committee that to Rule 7, dealing with the election of ordinary members, the following words shall be added: "Not more than twenty members shall be elected annually." On a vote being taken on the question of limitation of members twenty-six were for and twenty-two against the change. It was, however, decided to pass the rule without the addition, and to leave to the Committee the subject of limiting the number of members chosen for election.

This brings the history of the Society to the end of March, 1926, which is exactly fifty years from its foundation. In consequence of the amount 
of time occupied by the negotiations for the acquisition of the Journal of Physiology and the consequent changes in the constitution of the Society, it was not found possible to make arrangements for the Jubilee celebration during 1926 . This was accordingly deferred until the following year. The arrangements which were suggested included the following:

1. A banquet to be held in London on Saturday, May 13th, 1927, to which eminent foreign physiologists should be invited. This was duly held.

2. A commemorative medal to be struck. This suggestion was not acted upon.

3. A history of the Society during the first fifty years of its existence to be published in the Journal of Physiology. Now carried out.

This concludes what may be termed the domestic record of the Society during its first fifty years. But no account of its history can be considered complete which does not refer to the influence it has had in promoting the study of the science for the advancement and protection of which it was instituted. All important advances in Physiology made in Great Britain during the period with which we have been dealing have been brought in the first instance before the Physiological Society: it would require a considerable volume even to indicate their titles. But fortunately this is not necessary, for the Journal of Physiology from 1883 onwards contains a continuous account of the communications which have been made by its members - a record of which any Society may be proud.

Both the Physiological Society of Great Britain and the Société de Biologie of Paris - the foundation of which slightly preceded our ownhave furnished models which have been copied in many other countries by the establishment of associations with similar aims, and even with similar titles. As a result of this activity the wave of advance in Physiology, which was started by William Harvey three hundred years ago, is moving on so extensive a front that it is no longer possible for an individual worker to deal with any but a segment of the ever widening circle. Hence the establishment within recent years of daughter societies for the special study of certain parts of the subject such as Biochemistry and Experimental Biology. But the budding off of these has produced no deterioration either in the personnel or in the scientific activity of the parent Society. And we may rest assured that at the celebration of the centenary of the Physiological Society in 1976 our successors will be found to have worthily continued the work which in 1876 was begun so auspiciously by their, and our, predecessors. 
rcin.org.pl 


\section{INDEX}

Special notices are indicated by the heavier numerals.

Acland, Sir Henry, present as guest, 70

Acland, Theodore Dyke, elected, 98

Adair, G. S., elected, 164

Adami, J. G., elected, 85

Adrian, E. D., elected, 155; appointed Hon. Secretary and editor of Proceedings, 167; appointed one of the editors of Journal of Physiology, 179

Aikin, W. A., elected, 138

Alcock, N. H., elected, 124, 125; presides at meeting, 142; death reported to Society, 151

Alexander, present as guest, 50

Allbutt, Sir Clifford, present as guest, 103

Allchin, W. H., elected, 44

Allen, F. J., elected, 87, 88

Allmann, G. J., present as guest, 42

American Biological Societies, greeting from, 153; consulted regarding Physiological Abstracts, 172, 173

American Physiological Society, consultation with, concerning Protein Nomenclature, 135, 137

Anatomical Society, foundation of, 3

Anatomy, Journal of, foundation of, 3

Anderson, Sir Hugh Kenneth, present as guest, 87; elected, 105

Andrewes, F. W., elected, 120

Anrep, G. V., elected, 151

Antivivisection, see Vivisection

Armstrong, E. Frankland, elected, 132; reelected, 146

Armstrong, H. E., 132; present as guest, 136

Arnold, Mr, present as guest, 145

Arrhenius, S., communications from, regarding Pavlov Fund, 159, 163

Asdell, S. A., elected, 170

Ashdown, H. H., present as guest, 85, 86, 93; elected, 94

Association for the Advancement of Medicine by Research, 73, 109

Atwater, W. O., present as guest, 129, 132

Azuma, R., elected, 172

Babkin, S., elected, 168, 169

Bain, W., elected, 129

Bainbridge, F. A., elected, 124; death reported to Society and vote of sympathy to Mrs Bainbridge passed, 165

Bainbridge, Henrietta, elected, 177

Baker, Morrant, connexion with Kirkes' Physiology, 55

Balfour, Francis Maitland, original member, 13; present at inaugural dinner (signature), 14; biography (with portrait), 37-39; presides at meeting, 51 ; resolution regarding death of, 68

Balfour, Isaac Bayley, present as guest, 86
Balfour, Ruth, elected, 162

Ballance, Sir Charles A., present as guest, 90 ; elected, 103

Baly, E. C. C., present as guest, 145

Banting, F. G., elected, 170, 171

Barclay-Smith, E., elected, 132

Barcroft, Joseph, elected, 124; appointed Hon. Secretary, 141; resigns Secretaryship, 159

de Barenne, J. G. Dusser, elected, 172

Barger, G., present as guest, 133; elected,142

Barnard, Harold L., present as guest, 116; elected, 117

Barr, Sir James, present as guest, 145

Barratt, J. O. W., elected, 123

Barrett, Sir J. W., elected, 77; resigns membership, 85; re-elected, 110

Barry, J., elected, 160

St Bartholomew's Hospital, first meeting at, 115

Basel, First International Physiological Congress held at, 91

Basiswar Sen, elected, 172

Bateson, William, present as guest, 99

Batten, F. E., elected, 122, 123; death reported to Society, 157

Baxter, Buchanan, present as guest, 58

Bayliss, L. E., elected, 169, 170

Bayliss, Sir William Maddox, present as guest, 79, 86; biographical notice, with portrait, 79, elected, 94; represents Society at Jubilee of Oxford Museum, 139; Senior Secretary, 140; elected Treasurer, 167; vote of thanks for services as Secretary, 167; editor in chief of Physiological Abstracts, 169; resigns editorship, 169; death reported to Society and vote of condolence with Lady Bayliss adopted, 173

Bazett, H. C., elected, 153

Beale, P. T., elected, 101

Beattie, J. M., present as guest, 136

Bedford College, first meeting at, 177

Beddard, A. P., present as guest, 122; elected, 122

Beevor, Charles Edward, present as guest, 83; elected, 85

Bell, Jeffrey, elected, 53

Benedict, F. G., calorimeter of, at Carnegie Nutrition Laboratory, 129

Bennett, Hughes, professor of Institutes of Medicine in Edinburgh, Memorial to, 125

Bennett, present as guest, 78

Bern, International Physiological Congress at (1895), 112, 113, 114

Bernard, Claude, Letter to Société de Biologie regarding death of, 47; reply, 49 ; subscription of Society to memorial to, 94 
Berry, George (afterwards Sir George Berry, M.P.), present as guest, 125

Berry, R. J. A., present as guest, 125

Bettany, G. F., elected, 44; resigns membership, 85

Biochemical Society, joint meeting with, Discussion on Fat and Carbohydrate in Nutrition at, 157

Birch, A. de Burgh, elected, 101

Blake, James, elected, 82, 83; presides at meeting, 84

Blix, Magnus (Lund), letter from, 93

Bohr, Christian, attends meeting at University College and dinner, 107

Du Bois-Reymond, Emil, elected Honorary Member, 104; death reported to the Society, 116

Du Bois-Reymond, René, present as guest, 100

Bokenham, T. D., elected, 97

Bolam, Sir Robert H., elected, 113, 114

Bolton, Charles, elected, 137

Bond, Muriel, elected, 162

Boock, Ellen, elected, 166

Bottazzi, F., present as guest, 121

Botwood, C. A., elected, 170

Bowditch, Henry, working with Ludwig, 33 ; present at dinner to foreign physiologists in 1881, 60, 62

Bowkett, present as guest, 51

Bowman, Sir William, present as guest at inaugural dinner, 15; biographica] notice, with portrait, 15; elected Honorary Member, 69; present at Cambridge meeting, 1888, 87; testimonial to, 90

Boyce, Sir Rubert, present as guest, 89, 90 ; biographical notice, 89 ; elected, 98 ; death reported to the Society, 147

Boycott, A. E., elected, 123, 124

Bradford, Sir John Rose, present as guest, 79 ; elected, 82

Bramwell, J. C., elected, 166

Briscoe, Lady Grace M., elected, 167

Broadhurst, H. C., elected, 160, 161

Brocklehurst, R. J., elected, 177

Brodie, Thomas Gregor, elected, 101; biographical notice with portrait, 101; presides at meeting, 119; elected Secretary, 127; resigns Secretaryship on appointment to Toronto, 140; memento to, from members of the Society, 140; death of, reported to the Society and vote of sympathy with family passed, 155

Brooks, Walter Tyrrell, present as guest, 67,72 ; elected, 80

Brown, J. Graham, elected, 123; death of, reported to the Society, 180

Brown, Sanger, present as guest, 82, 83

Brown, T. Graham, elected, 141; presides at meeting, 177

Brown, William, elected, 144

Brown, W. E. L., elected, 164

Brown, W. Langdon, elected, 115
Brown-Séquard, E., present at dinner to foreign physiologists in 1881, 60, 61

Bruce, Alexander, elected, 97, 98; death reported to the Society, 147

Bruce, A. Ninian, present as guest, 136

Bruce, Mitchell, present as guest, 40, 41

v. Brücke, memorial to, 103

Bruns, L. (Hanover), present as guest, 110

Brunton, Sir Thomas Lauder, attends meeting founding the Society, 8; appointed member of Committee for drawing up Rules, 8; original member, 13 ; present at inaugural dinner (signature), 14; biography (with portrait), 31; application to Scientific Grants Committee, 43; elected on first Committee, 45 ; demonstrations by, 64, 65, 71; presides at meetings, 42,65

Bryce, T. H., present as guest, 129

Buchanan, Florence, present as visitor, 114, 115; elected, 154

Buchner, H., working with Ludwig, 33

Buckmaster, G. A., elected, 77

Bullar, J. F., present as guest, 45, 51

Bulloch, William, present as guest, 115, 116, elected, 120

Bullot, G., elected, 124; death reported to Society, 134

Bunch, J. le Mare, elected, 120

Burch, G. J., present as guest, 86, 90; elected, 108

Burgess, Norman, elected, 174

Burlend, T. H., elected, 162

Burn, J. H., elected, 162; sub-editor of Physiological Abstracts, 169

Burns, David, elected, 160

Burridge, W., elected, 147

Burt, Cyril, present as guest, 145

Buxton, Dudley W., present as guest, 78; elected, 103

Bywaters, H. W., elected, 140

Cadman, A. W., elected, 123

Cajal, Ramón y, dinner to, by Physiological and Neurological Societies, 109

Caldwell, W. H., present as guest, 72; demonstration by, 72 *

Camis, M., elected, 142

Cambridge, Prælectorship of Physiology established at Trinity College, 3; International Congress of Physiology at, 121; Meeting of Society at, during visit of British Association, 131; list of members and guests at the dinner, 132

Cameron, R. K., elected, 163

Campbell, H., elected, 106

Campbell, J. Argyll, elected, 157

Campbell, J. M. H., elected, 162

Camus (Paris), present as guest, 132

Cannon, W. B. (Harvard), present as guest, 132

Cardiff, first meeting at, 177

Cardwell, Lord, Chairman of First Royal Commission on Vivisection, 4 
Carleton, H. M., elected, 172

Carlier, E. Wace, elected, 166

Carpenter, Dr and Mrs Thorne, present as guests, 176

Carpenter, W. B., invited to become original member but declines, 13 ; present as guest atinaugural dinner, 15; biographical notice, 16; elected Honorary Member, 69 ; presides at meeting, 71; death, 82

Carter, Captain, present as guest, 145

Cartwell, present as guest, 59

Cash, John Theodore, present as guest, 58, 59; elected, 63; demonstration by, 71

Cathcart, E. P., elected, 129, 130

Caton, Miss, Letter from, 179

Caton, Richard, original member, 13; present at inaugural dinner (signature), 14; presides at meeting, 58; Professor of Physiology at Liverpool, 66; letter from, 140; present at dinner, 144; death of, reported to the Society and letter of condolence sent to relations, 178,180

Channon, H. T., elected, 172

Chapman, H. G., present as guest, 90; elected, 129

Charing Cross Hospital, First meeting at, 97

Charles, Arthur, 61

Charles, J. J., present as guest, 60, 61

Chauveau, A. (Paris), present at dinner to foreign physiologists, 1881, 60, 62; elected Honorary Member, 104; death of, reported to Society, 155

Cheyne, Sir William Watson, present as guest, 49, 58, 71; demonstration by, 71; elected, 77

Chick, Miss Harriet, present as guest, 145; elected, 156

Clark, Sir Andrew, resolution regarding death of, 107

Clark, A. J., elected, 149

Clark, G. A., elected, 162

Clark, G. H., elected, 145

Clark, W. G., influence of, in institution of Prælectorship of Physiology in Trinity College, 3

Clarke, Adams, attends as guest, 52

Clarke, J. Mitchell, elected, 110; death reported to Society, 157

Clarke, R. H., present as guest, 79; elected, 144

Coats, Joseph, present as guest, 44, 48

Cobbett, Louis, elected, 108

Coffey, D. J., elected, 124

Cohen, H., elected, 177

Cohnheim, memorial to, 78

Cole, S. W., elected, 127

Colls, P. C., elected, 113

Collingwood, B. J., elected, 131

Collip, J. B., elected, 159, 160

Commissions, Royal, on Vivisection, see Vivisection

Congresses: International Medical Congress of 1881; invitation to foreign physiologists, $53,55,56,60$, dinner to foreign physiologists, list of members and guests present, 60; International Medical Congress of 1913, river excursion, 76, 150, special meeting at University College, 150, dinner to foreign physiologists, 150 ; International Physiological Congress of 1899 (Basel), 25, 85, 86, 87, 91; number present at the several Congresses, 91; Congress of 1892 (Liége), 99, 100, 105; Congress of 1895 (Bern), 112, 113; Congress of 1898 (Cambridge), 121; Congress of 1907, 138; Interallied Congress of 1920 (Paris), 158; Congress of 1923 (Edinburgh), 167

Conjoint Laboratories, first meeting in, 96

Connet, Helene, elected, 164

Conway, E. J., elected, 172

Conway, Ruth E., elected, 168

Cook, F., elected, 148

Coope, R., elected, 172

Cooper, Sybil, elected, 170

Copeland, A. J., elected, 177

Copeman, S. Monckton, present as guest, 87, 90; elected, 92

Covell, S. J., elected, 166

Cow, Douglas, elected, 151

Coward, Catherine, elected, 167

Craik, Sir Henry, present as guest, 49

Cramer, William, present as guest, 129; elected, 132

Crawford, J. H., elected, 167

Crew, F. A. E., elected, 169

Cripps, Harrison, present as guest, 50

Crookshank, E. M., elected, 82

Crowden, G. P., elected, 162

Cruickshank, E. W. H., elected, 164

Cullis, Winifred C., elected, 154; first woman on Committee of Society, 159; presides at meeting, 160

Cunningham, G., elected, 92

Cunningham, J. J., present as guest, 136

Cunningham (New York), presentas guest, 99

Curnow, John, present as guest, 73

Cushny, A. R., present as guest, 133; elected, 133; biographical sketch with portrait, 133; appointed to represent the Society at Conference on British Pharmacopœia, 178; death of, reported to Society and vote of condolence to relatives passed, 179

Dakin, Dr, present as guest, 145

Dakin, H. D., present as guest, 130; elected, 132

Dale, H. H., elected, 124; presides at meeting, 178

Daly, I. de B., elected, 160

Damant, G. C. C., elected, 139

Darwin, Charles, Honorary Member, 13; resolution regarding death of, 68

Darwin, Sir Francis, attends meeting founding the Society, 8; original member, 13; present at inaugural dinner (signature), 14; biographical notice, 49; resigns membership, 86 
Darwin, Sir Horace, connexion with Cambridge Seientific Instrument Co., 27; present as guest, 59, 60; apparatus for artificial respiration, 58

Dastre, A. (Paris), present as guest at the dinner to foreign physiologists, 60,61

Davies, H. W., elected, 159, 160

Dean, G., elected, 124, 125

Dean, H. P., present as guest, 85; elected, 92,93

Dean, H. R., elected, 129; re-elected, 149

de Decker, Miss G., elected, 164

Delépine, Sheridan, present as guest, 67; elected, 82

Dent, Thomas Clinton, elected, 73; presides at meetings, 78

Dewar, Sir James, present as guest, 48

Dew-Smith, A. G., original member, 13; present at inaugural dinner (signature), 14; biography (with portrait), 26, 27; resignation from membership, 123

Dickinson, W. L., elected 97

Dickson (? G. A.), present as guest, 136

Dilling, W. J., elected, 146

Dixey, F. A., elected, 82, 83

Dixon, W. E., present as guest, 114; elected, 123; appointed to represent the Society at Conference on British Pharmacopœia, 178

Dodds, E. C., elected, 164

Dodgson, R. W., elected, 123

Donders, F. C. (Utrecht), guest at inaugural dinner, 15 ; testimonial to, 85,86 ; letter from, 87; death of, 90

Donegan, J. F., elected, 172

Donnan, F. G., present as guest, 145

Dott, Norman M., elected, 166, 167

Douglas, C. Gordon, elected, 136

Douglas, J. Sholto, elected, 142

Dowdeswell, George, present as guest, 64

Downs, A. W., elected, 164

Doyne, present as guest, 86

Draper, V. W., elected, 148; death reported to the Society, 156

Drechsel, working with Ludwig, 33; death reported to Society, 119; Memorial Fund, 119; subscriptions to, 121, 122

Dreyer, Georges, present as guest, 128; elected, 141

Dreyer, N. B., elected, 167

Drummond, J. C., elected, 155

Drury, A. N., elected, 160

Dryerre, Henry, elected, 166, 167

Drysdale, J. H., present as guest, 128

Dublin, Trinity College, address on occasion of bicentenary, 148

Dubois, R. (Lyons), present as guest, 110

Duffield, F. A., elected, 160

Dunhill, T. P., elected, 168

Dunlop, J. C., present as guest, 125

Dunn, J. Shaw, elected, 159, 160

Dunstan, Sir Wyndham R., present as guest, 114, 115, elected, 117
Dupuy, Eugène (Paris), present as guest, 85, 110 ; elected, 111

Durham, Florence M., elected, 160

Durham, H. E., elected, 111

Dyer, Sir W. T. Thiselton, original member, 13; present at inaugural dinner (signature), 14

Earle, H. G., elected, 163, 164

Eaves, Miss E. C., present as guest, 136; elected, 156

Edgeworth, F. H., elected, 101

Edie, E. S., elected, 132

Edinburgh, invitation from, 92, 95, 96, 120, 121, 158; first regular meeting in, 125; inauguration of new laboratory at, 125, names of those present at dinner, 125, 135; other meetings at, 146, 158, 176; Congress of 1923 held in, 167, 170

Edkins, J. S., present as guest, 80; elected, 85 ; presides at meeting, 177

Edmunds, Arthur, elected, 115

Edmunds, W., elected, 106

Edridge-Green, F. W., elected, 144.

Ehrlich, P. (Frankfurt), elected an Honorary Member, 127; death of, reported to Society, 154

Eichholtz, A., elected, 110

Eichholtz, Fritz, elected, 174

Einthoven, W. (Leiden), present as guest, 146; elected an Honorary Member, 170; invitation from, 173; letter of thanks to, 176; death of, 176

Eliot, George, influence of, in establishing Prælectorship of Physiology in Cambridge, 3

Elliot, R. H., present as guest, 129; elected, 130, 131

Elliott, T. R., present as guest, 128, 130; elected, 131

Ellis, A. W. M., elected, 174, 175

Ellison, F. O'B., elected, 142

Engelmann, T. W. (Berlin), present as guest, 110; entertained at dinner, 112; elected an Honorary Member, 121; death reported to Society, 143

Erichsen, Sir John Eric, Member of first Vivisection Commission, 5; Chief Inspector under the Act 39-40 Cap. 77, 5

Evans, present as guest, 67, 71, 72; demonstration by, 71

Evans, C. Lovatt, elected, 146; assistant editor of Physiological Abstracts, 168; presides at meetings, 171

Eve, F. C., present as guest, 72; elected, 118

Ewald, C. A. (Berlin), present as guest, 60, 61

Ewart, James Cossar, elected, 44, 45; present as guest, 136

Ewart, William, elected, 82

Exner, letter from, 103

Eyre, J. W. H., elected, 123, 124

Fano, G., working with Ludwig, 33

Da Fano, C., elected, 158 
Farmer, Sir J. B., present as guest, 86, 90; elected, 122, 123

Fawcett, J., elected, 105

Fayrer, Sir Joseph, present as guest, 42

Fearon, W. R., elected, 164

Feldman, I., elected, 162

Fenn, W. O., elected, 168

Fenwick, present as guest, 70

Ferrier, Sir David, attends meeting founding the Society, 8; appointed member of Committee for drawing up Rules, 8; original member, 13; present at inaugural dinner (signature), 14; prosecution of, by anti-vivisectionists, 67; demonstration by, 71 ; presides at meetings, 43,49 ; election as Honorary Member referred to, 15

Filehne, W. (Breslau), present as guest, 109, 110

Findlay, G. Marshall, elected, 172

Fischer, Emil (Berlin), elected an Honorary Member, 143; death reported to Society, 159

Fisher, present as guest, 90

Fitzgerald, present as guest, 64

Flack, Martin, elected, 144.

Flechsig, assistant to Ludwig, 33

Fleming, G. B., elected, 172

Fleming, R. A., present as guest, 136

Fletcher, Herbert Morley, elected, 106

Fletcher, Sir Walter Morley, biography of Langley, 40; elected, 120

Flexner, Simon, present as guest, 130

Flood, present as guest, 51

Florey, H., elected, 177

Forrest, W. O., elected, 177

Forsyth, D., elected, 136

Foster, Sir Michael, appointed to Chair of Practical Physiology in University College, 2; appointed to Prælectorship in Physiology, Trinity College, Cambridge, 4 ; attends meeting and proposes resolution founding the Society, 8; appointed member of Committee for drawing up Rules, 8; original member, 13; takes chair at inaugural dinner (signature), 14; biography (with portrait), 24-27; elected on first Committee, 45; presides at dinner to foreign physiologists (1881), 60; raises question of President of the Society, 96; presides at meetings, 14, 51, $52,59,67,72,80,86,103,112,118,119$; death reported to the Society, 137, resolution regarding, sent to Lady Foster and her reply, 137; Loss to Society referred to in Secretaries' Report, 138

Founders of the Society, biographical notices of, 17-40

France, E. P., present as guest, 83, 86

Franklin, K. J., elected, 168

François-Franck, C. A. (Paris), present as guest at inaugural dinner, 15 ; also at dinner to foreign physiologists (1881), 60

Fraser, E. H., present as guest, 125

Fraser, F. R., elected, 162
Fraser, Sir Thomas, elected, 73

Fredericq, Léon (Liége), president International Physiological Congress of 1892, 105; present as guest, 110

Frost, J., elected, 172

Fulton, John, elected, 170, 171

Funk, Casimir, elected, 149

Furusawa, K., elected, 177

Gaddum, T. H., elected, 177

Gadow, Hans, present as guest, 86, 87

Galton, Sir Francis, attends meeting founding the Society, 7; appointed member of Committee for drawing up Rules, 8; original member, 13; present at inaugural dinner (signature), 14; biography (with portrait), 19, 20; resignation of membership, 68 ; presides at meetings, $48,49,51$

Galvani, 1

Gamgee, Arthur, original member, 13; biography (with portrait), 29, 30; application to Scientific Grants Committee, 43 ; presides at meeting, 46 ; demonstrations by, 49, 59; suggests discussions, 78 ; death reported to Society and resolution of sympathy with Mrs Gamgee adopted, 141

Gardiner, Walter, elected, 77, 78

Garrod, Alfred H., invited to become original member but declines, 13

Garrod, Sir Archibald E., elected, 108

Garry, R., elected, 177

Garwen, H. S. D., elected, 177

Gask, G. E., elected, 168

Gaskell, John Foster, present as guest, 128; elected, 142

Gaskell, Walter Holbrook, attends meeting founding the Society, 8; original member, 13 ; present at inaugural dinner (signature), 14; biography (with portrait), 33, 34; demonstrations by, 58, 59, 67, 71; elected Treasurer, 77; presides at meetings, 99, 112; resigns Treasurership, 114; vote of thanks to, 117; presentation to, 118; death reported to Society and vote of sympathy with family passed, 153

Gasser, H. S., elected, 170

Gaule, J. (Zürich), present as guest, 110

Gayet, present as guest, 43

Geddes, Patrick, present as guest, 46

Gibbs, Owen S., elected, 174

Gibson, George, present as guest, 125

Gibson, J. Lockhart, elected, 111

Giles, J. A., Inspector under the Act 39-40 Vic. cap. 77,5

Gilding, H. P., elected, 177

Gillespie, A. L., present as guest, 125

Glanville, Mortimer, present as guest, 75

Glasgow, first meeting at, 141; combined meeting with Section of Physiology of British Association, 167

Gley, E. (Paris), elected an Honorary Member, 170 
Goadby, Sir K. W., elected, 140

Goldblatt, H., elected, 172

Golding-Bird, C. H., present as guest, 52; elected, 53; presides at meeting, 106

Golla, D. F. L., elected, 172

Goltz, F. (Strasburg), present at dinner to foreign physiologists, 60,61

Goodall, Alexander, present as guest, 136; elected, 138

Goodbody, F. W., elected, 123

Gorki, M., communication from, regarding Pavlov Fund, 163

Gotch, Francis, obituary notice of Burdon Sanderson, 23; demonstrations by, 65, 70; biographical notice (with portrait), 66; elected, 69 ; presides at meetings, 113 , $118,122,126,128,133,136,138,139,141$, $144,146,148$; death of, and resolution of sympathy with his family, 151

Gowers, Sir W. R., present as guest, 63

Graham, George, elected, 151

Gray, James, elected, 170

Green, Joseph Reynolds, present as guest, 78; elected, 80 ; biographical notice, 81

Greenfield, W. S., present as guest, 136

Greenwood, M., elected, 136

Grey, Egerton, elected, 156

Griffiths, Joseph, elected, 92, 93

Gross, L., elected, 169

Groves, J. W., present as guest, 50, 51; elected 53; demonstrations by, 66, 71

Grünbaum (afterwards Leyton), A. S., elected, 105

Grünbaum, Mrs A. S., present as guest, 145

Grünbaum (afterwards Leyton), O. F. F., elected, 120

Grünhagen, W. A. (Königsberg), present at dinner to foreign physiologists, 60,62

Gulland, G. Lovell, elected, 113

Gunn, James A., elected, 146

Gunn, J. C. W., elected, 152

Guy's Hospital, first meeting at, 106

Gye, W. E., elected, 160, 161

Haas, Paul, present as guest, 134

Haldane, J. B. S., elected, 160, 161

Haldane, John Scott, present as guest, 84; elected, 85; presides at meeting, 110

Hale-White, Sir William, appreciation of Pavy, 28; elected, 92, 93

Halford, B., elected, 110

Hall, I. Walker, elected, 124, 125; resigns membership, 137

Hall, Major, D.S.O., present as guest, 134

Halliburton, William Dobinson, connexion with Kirkes' Physiology, 55; communication by, 74; biographical sketch, 75; present as guest, 78; elected, 80 ; presides at meetings, $95,98,103,106,108,112$, $114,121,125,127,130,132,134,137,138$, $140,142,147,148,151,153,154,155,156$, $157,159,162,165$; illness of, and greetings of Society to, 168; resignation of editorship of Physiological Abstracts, 168
Ham, C. E., elected, 132

Hamill, J. M., elected, 133

Hamill, P., elected, 139

Hamilton, D. G., elected, 110

Handbook for the Physiological Laboratory, 31

Hankin, E. H., elected, 97

Hanley, Miss, present as guest, 145

Harden, A., elected, 131

Hardikar, S. W., elected, 168

Hardy, Sir William B., present as guest, 89; elected, 101

Hare, present as guest, 86

Harington, C. R., elected, 168

Harley, George, institutes Course of Practical Physiology at University College, 2

Harley, Vaughan, elected, 108

Harris, D. Fraser, elected, 126

Harris, D. T., sub-editor of Physiological Abstracts, 169

Harris, D. Vincent, present as guest, 55, 86; elected, 103

Harrison, G. A., elected, 168, 169

Hart, Berry, present as guest, 125

Hart, Sir Ernest, present as guest, 43, 47, 59

Hartley, Sir Percival Horton-Smith, elected 115

Hartley, P., elected, 138

Hartridge, H., elected, 149, 150

Hartwell, Gladys, elected, 165

Harvey, Reuben J., present as guest, 60; elected, 63 ; death, 65

Harvey, William, date and place of birth, 17; commemoration of tercentenary, 48; portraits of, 53; connexion with Caius College, 48, 95

Harvey, W. H., elected, 139

Haslam, G., elected, 85

Haslam, H. C., elected, 124

Hassan, A., elected, 165

Hawker, H., present as guest, 117; elected, 122

Haycraft, John Berry, present as guest, 60, 80; elected, 97; death of, reported to Society, 168

Hay-Mouatt, J. R., elected, 165

Head, Sir Henry, present as guest, 72; elected, 85; proposes amalgamation with Medical Societies, 133; elected an Honorary Member, 178; letter from, 179

Heape, Walter, present as guest, 77

Heathcote, H. St A., elected, 165, 166

Heaton, T. B., elected, 165, 166

Hedin, S. G., elected, 124; resigns membership, 137

Heger, Paul (Brussels), letter from regarding Congress of 1892, 100; present as guest, 110

Heidenhain, R., death reported to Society, 119

Hele, T. S., elected, 138

Helmholtz, H., 1

Hemmingway, A., elected, 177

Henderson, E. E., present as guest, 128; elected, 129

Henderson, V. E., elected, 134 
Henderson, Yandell, elected, 147

Herdman, Sir William, present as guest, 145 Hering, Ewald (Leipzig), elected an Honorary Member, 127; death reported to Society, 154

Hermann, L. (Königsberg), Lehrbuch, translated by Gamgee, 30; present as guest, 110; elected an Honorary Member, 127; death reported to Society, 153

Herring, P. T., present as guest, 125; elected, 126

Herroun, E. F., present as guest, 72, 76; demonstration by, 72; elected, 77; presides at meeting, 89

Herz (afterwards Hurst), A. F., elected, 138

Herzen (Geneva), letter from, regarding testimonial to M. Schiff, 105

Hewer, Evelyn, elected, 157

Hewitt, J. A., elected, 159, 160; sub-editor of Physiological Abstracts, 169

Hewlett, R. T., elected, 103, 104

Hickman, H. B., elected, 160, 161

Hickson, Sydney J., elected, 77

Hickson, Sylvia K., elected, 170

Hill, Alexander, elected, 80, 81; presides at dinner to foreign physiologists, 132

Hill, A. Croft, elected, 123

Hill, A. V., present as guest, 142; elected, 147; presides at meetings, 167, 170, 173; congratulations of Society on his receiving Nobel Prize, 171; appointed one of the editors of the Journal of Physiology, 179

Hill, Leonard, elected, 97; appointed Secretary, 113; presides at meeting, 116; appointed editor of Proceedings, 120; resigns Secretaryship, 127; vote of thanks to, 128

Hilton, R., elected, 169

His, Wilhelm (Leipzig), present at dinner to foreign physiologists, 60,61

Hobhouse, present as guest, 93

Hogben, L. T., elected, 169

Holmes, Gordon, elected, 153

Holmgren, testimonial to, 93; letter from, 102

Hopkins, Sir Frederick Gowland, elected, 103, 104

Horder, Sir Thomas, elected, 123; resigns membership, 137

Horne, R. M., elected, 113; death reported to Society, 116

Horsley, Sir Victor Alexander Haden, communication by, 74; biographical notice with portrait, 74; elected, 77; death of, reported to Society and vote of sympathy with Lady Horsley adopted, 155

Horton-Smith, see Hartley

Horwart (?), present as guest, 69

Horwicks (?), present as guest, 69

Howard (New York), present as guest, 47

Howell, C. M. Hinds, elected, 145, 146

Howell, W. H. (Baltimore), elected an Honorary Member, 156

Huggett, A. St G. H. M., elected, 165, 166
Humphry, Sir George Murray, founder of Journal of Anatomy and first President of Anatomical Society, 3; influence on Physiology in Cambridge, 3 ; present at meeting founding the Society, 8 ; invited to become original member, 13; resignation, 13 ; present as guest, $59,63,72$

Hunter, Andrew, present as guest, 129; elected, 129

Hunter, W., present as guest, 86, 123; elected, 87, 88; re-elected, 124

Hurtley, W. H., elected, 141

Hutchens, H. J., elected, 148

Hutchison, Robert, 118

Huxley, Thomas Henry, recommends Michael Foster for Prælectorship of Physiology at Cambridge, 4 ; member of first Vivisection Commission, 5; attends meeting founding the Society, 7; takes chair at adjourned meeting to consider Rules, 8; original member, 13; biography (with portrait), 20-22; his opinion of Wharton Jones, 20; presides at meeting, 45; signature, 45; elected Honorary Member, 69; letter from, 69

Imrie, C. G., elected, 162

Inchley, O., elected, 167

Inspectors under Vivisection Act, 5

Jackson, J. Hughlings, elected, 82; biographical notice, 82, 83; death reported to the Society, 147

Jackson, Lilias Charlotte, elected, 155

Jacobi, present at dinner to foreign physiologists in 1881, 60

Jarisch, A. (Innsbrück), present as guest, 176

Jessop, H., present as guest, 88

Joffe, J., elected, 160

Johannson (Stockholm), present as guest, 130,132

Johnston, William, present as guest, 145

Jolly, W. A., elected, 133

Jona, J. L., elected, 146

Jones, E. Lloyd, elected, 101

Jones, Wharton, influence on Huxley and Lister, 20, 21

Jordan-Lloyd, Dorothy, elected, 159

Journal of Physiology, Establishment by Michael Foster and Dew-Smith, 26, 27; publication of Proceedings in, 73, 75; financial contributions to, 88; relations with Society, 91, 102, 107, 108; change of proprietorship, 107; acquisition by the Society, 177

Jubilee of the Physiological Society, suggested arrangements for celebration, 180, 181

Kanthack, A. H., succeeds Roy at Cambridge, 52; present as guest, 104; elected, 105

Katz, L. N., elected, 174

Kay, Gladys, elected, 170 
Kay, H. D., elected, 167

Kellaway, Charles H., elected, 157

Kennaway, E. L., elected, 141

Kent, A. F. Stanley, elected, 85

Ker, Dr, present as guest, 125

Kerridge, Mrs P. M., elected, 174.

Kinosita, R., elected, 177

Kirkes' Physiology, 55

Klein, Edward Emmanuel, attends meeting founding the Society, 8; original member, 13 ; present at inaugural dinner (signature), 14; biography (with portrait), 31, 32; demonstrations by, 55, 58, 64, 65, $67,71,72$; presides at meetings, 59, 66, $69,115,119$; resigns membership, 137

Knowlton, F. P., elected, 147

Knox, G. N., present as guest, 142

Koch (Berlin), present as guest, 133

Kölliker, A. (Würzburg), friendship with Sharpey, 18

Körösy (Budapest), present as guest, 132

Kossel, A. (Heidelberg), present as guest, 132; congratulations of Society on receiving Nobel Prize for Medicine, 144

Krause (Philadelphia), present as guest, 146

Krause, R. A., elected, 149

Krogh, Aug., elected, 149, congratulations of Society on receiving Nobel Prize, 161

Kronecker, Hugo, assistant to Ludwig, 33; attends dinner as guest, 60,61 ; letter about Congress of 1892, 100; attends meeting and dinner as guest, 107; presides over International Physiological Congress at Bern in 1895, 112, 114; address to, on attaining 70th year, 140; elected an Honorary Member, 14.0; present at dinner, 141; death reported to Society and resolution of sympathy with Frau Kronecker adopted, 152

Kühne, W., Croonian Lecturer, 86; dinner to, 86 ; letter to, 115 ; elected Honorary Member, 121; death reported to Society, 124

Kuno, Yas, elected, 155

Laidlaw, P. P., present as guest, 130; elected, 138

Lamb, F. W., elected, 146

Lambe, present as guest, 47

Lambie, C. G., elected, 164

Langley, John Newport, original member, 13; present at inaugural dinner (signature), 14; biography (with portrait), 39, 40; application to Scientific Grants Committee, 43; demonstrations by, 59, 65,66 ; becomes proprietor and editor of Journal, 107; letter from, re Journal, 107; presides at meetings, 51, 84, 106, 114, 121 , $128,133,135,141,154,165,171,175$; death reported to Society and vote of sympathy with Mrs Langley, 177

Langley, Mrs, letter from, in reply to expression of sympathy, 177, 178; letter to, re Journal, 178; letter in reply, 179

Lankester, Sir E. Ray, original member, 13; application to Scientific Grants Committee, 43

Latham, Dr, present as guest, 59

Lawrence, R. D., elected, 177

Laws, present as guest, 70

Lawson, Robert, present as guest, 44

Lazarus-Barlow, W. S., elected, 113, 114.

Lea, Arthur Sheridan, attends meeting as visitor, 40; biographical notice (with portrait), 41; elected, 44; demonstration by, 58

Leathes, J. B., present as guest, 113; elected, 113; appointed Honorary Secretary, 140; resigns Secretaryship on accepting chair at Toronto, 141; transfers to Sheffield, 152; appointed one of the editors of the Journal of Physiology, 179

Ledingham, J. C. G., elected, 139

van Leeuwen, Storm, letter of thanks to, 176

Leiden, meeting at, 171, 175; signatures of those present at the dinner, 175

Leigh, J. Randle, elected, 101, 102

Lépine (Lyons), present at dinner to foreign physiologists in 1881, 60, 61

Levy, A. G., elected, 140

Lewes, George Henry, influence of, in establishing Prælectorship of Physiology in Cambridge, 3 ; attends meeting and seconds resolution founding the Society, 8 ; member of Committee for drawing up Rules, 8; original member, 13; present at inaugural dinner (signature), 14; biography (with portrait), 19; elected on first Committee, 45 ; presides at meetings, 12, 40 ; death, 49

Lewis, Sir Thomas, elected, 129

Lewis, Timothy, present as guest, 50

Liddell, present as guest, 84

Liddell, E. G. T., elected, 166

Lieb, C. C., elected, 141

Liége, Second International Physiological Congress held in 1892, 105

Liljestrand, G., elected, 177

Lim, R. K. S., elected, 158

Lingard, Alfred, elected, 94.

Lister, Sir Joseph (afterwards Lord Lister), reference to Sharpey, 18; to Wharton Jones, 21; Life of, by Godlee, 21; elected Honorary Member, 104; death reported to Society, 148

Littlejohn, Harvey, present as guest, 125, 129,136

Liverpool, first meeting at, 140, 144; list of members and guests present, 145; invitation from Professors Sherrington and Moore, 148

Liversidge, A., present as guest, 49

Lloyd, W. G., elected, 152

Lochhead, James, present as guest, 136

Locke, F. S., elected, 122, 123

Loewi, present as guest, 128 
London Hospital, first meeting at, 116

Long, C. N. H., elected, 172

Lovèn, C. (Stockholm), present as guest at inaugural dinner, 15; present at dinner to foreign physiologists, 60,61

Lucas, Keith, present as guest, 128; elected, 131; biographical notice with portrait, 131; death of, reported to Society and vote of sympathy with Mrs Lucas adopted, 155

Luciani, L. (Rome), working with Ludwig, 33; elected an Honorary Member, 156; death reported to Society, 159

Ludwig, C., physiologists working with, 33; elected Honorary Member, 113; death of, reported to Society, 113

Lumsden, T., elected, 169

Lupton, Hartley, elected, 168

Lüscher, E., elected, 164

Lusk, Graham (New York), elected an Honorary Member, 170; present at meeting, 172

Lyle, H. Willoughby, elected, 115

Lythgoe, R. J., elected, 177

MacAlister, A., present as guest, 75; elected, 80

MacAlister, Sir Donald, present as guest, 55; elected, 69 ; presides at meetings, 80 , 89

Macallum, A. B., elected, 117

McCarrison, R., elected, 164

McCarthy, Jeremiah, original member, 13; present at inaugural dinner (signature), 14

McCay, Lt.-Col. D., elected, 145, 146

Macdonald, J. S., elected, 110; presides at meeting at Sheffield, 152; appointed to Liverpool, 152

McDonnell, Robert, original member, 13; presides at meetings, 47, 58; death of, 91

Macdougall, William, elected, 126

McDowall, R. J. S., elected, 162; presides at meeting, 179

MacFadyen, Allan, present as guest, 90; elected, 113

Macfadyean, Sir John, elected, 118

Mackay, George, present as guest, 125

MacKeith, H. M., elected, 168

MacKendrick, John G., attends meeting founding the Society and proposes resolution appointing Officers and Committee for drawing up Rules, 8; original member, 13; present at inaugural dinner (signature), 14; application to Scientific Grants Committee, 43; invitation from, 105; presides at meeting, 105; death of, reported to Society and letter of sympathy sent to relatives, 178

McKendrick, J. Soutar, letter from, 179

Mackenzie, Sir James, elected, 140; death reported to Society, 180

Maclean, Hugh, elected, 143, 144

Macleod, J. J. R., elected, 124.
McMunn, C. A., present as guest, 78; elected, 80; death reported to the Society, 147

MeNee, J. W., elected, 170, 171

McPhedran (Toronto), present as guest, 135

McSwiney, B. A., elected, 160, 161

McWilliam, John Alexander, communication by, 74, 75; present as guest, 75; elected, 77

Magee, H. E., elected, 174, 175

Magendie, 1

Magnus, R. (Utrecht), letter of thanks to, 176; death of, 176

Mahalanobis, S. C., elected, 123

Mahomed, present as guest, 54, 55

Malcolm, John, elected, 126

Mann, Gustav, elected, 111; death reported to Society, 165

Mansell-Moullin, present as guest, 51; elected, 92, 93; resigns membership, 116

Marcet, William, present as guest at inaugural dinner, 15, 16; present as guest, 54, 78; biographical notice, 54; elected, 82; death reported to the Society, 124

Marey, E. J. (Paris), present as guest at inaugural dinner, 15; elected Honorary Member, 121; death reported to Society, 130

Marshall, C. R., elected, 123

Marshall, E. K., elected, 169

Marshall, F. H. A., elected, 133

Marshall, Geoffrey, elected, 156

Marshall, John, attends meeting founding the Society, 8; original member, 13; present at inaugural dinner (signature), 14; elected Honorary Member, 69; presides at meeting, 50; death reported to Society, 97

Marshall, Milnes, association with Balfour, 38

Martin, Henry Newell, goes from University College to Cambridge (1870), and eventually to Johns Hopkins University, 4; original member, 13; present at inaugural dinner (signature), 14; biography (with portrait), 36, 37; demonstration, 67 ; death reported to Society, 116

Martin, Sidney H. C., present as guest, 78; elected, 80

Martin, Sir C. J., elected, 85; obituary notice of Starling, 90

Mason, present as guest, 72

Mathison, G. C., elected, 141

Mavrogordato, A., elected, 139

Maxwell, Leslie A. T., elected, 155

May, Otto, elected, 129, 130

May, W. Page, elected, 122; death reported to Society and resolution of sympathy with Mrs May adopted, 143

Mayer, Sigmund (Prag), present at dinner to foreign physiologists in 1881, 60, 61

Mayrs, E. Brice, elected, 164

Meakins, J. C., elected, 158 
Medical Microscopical Society, 51

Mekins, present as guest, 67,70

Meldola, R., present as guest, 79

Mellanby, E., present as guest, 128; elected, 142

Mellanby, J., 128; elected, 138; elected Hon. Secretary, 159; presides at meeting, 165; editor of Physiological Abstracts, 171

Melvin, G. Spencer, elected, 174

Menzies, J. A., elected, 108; re-elected, 147; death reported to Society and vote of sympathy to Mrs and Miss Menzies adopted, 165

Merkwalder, Joseph, elected, 152

Meyer, E. L., elected, 97

Meyer, Hans (Vienna), elected Honorary Member, 140; letter of condolence with Society on death of Langley, 178

Miles, present as guest, 67

Millais, J. Everett, elected, 94.

Miller, F. R., elected, 151

Mills, Wesley, present as guest, 130, 132

Milroy, J. A., elected, 124

Milroy, T. H., elected, 123, 124

Minot, C. S. (Harvard), present as guest, 132

Mines, G. R., elected, 143; biographical notice with portrait, 143; death reported to Society and vote of sympathy with family passed, 153

Mitchell, Miss, present as guest, 136

Mond, Ludwig, gift to Lister Institute, 136

Moore, Benjamin, present as guest, 112, 114; biographical notice with portrait, 112; elected, 115; invites Society to Liverpool, 148; death reported to Society and vote of sympathy with Mrs Moore passed, 166

Moore, Sandford, present as guest, 75

Moorhouse, V. H. K., elected, 152; reelected, 164

Morat, J. P. (Lyons), present at dinner to foreign physiologists, 60,61

Morris, Noah, elected, 168

Moseley, Henry Nottidge, present as guest, 42; elected, 44; resignation of, 91

Moseley, H. G. J., 42

Moshier, H. H., elected, 153

Mosso, Angelo (Turin), president of International Physiological Congress (1901), 25; working with Ludwig, 33; dinner to, 109; death of, reported to Society and letter of condolence sent to Signora Mosso, 144

Mott, Sir Frederick W., elected, 80; biographical notice with portrait, 81; presides at meetings, $97,101,107$

Mottram, V. H., elected, 142

Mudge, G. P., elected, 134

Muir, Robert, present as guest, 125; elected, 126

Müller, Franz (Berlin), present as guest, 134; elected, 139

Müller, J., 1
Mummery, J. Howard, present as guest, 100 ; elected, 103

Murray, J. A., elected, 153

Murray, Margaret, elected, 174

Murray, R. Milne, elected, 83; brings invitation from Royal College of Physicians, Edinburgh, 92

Mutch, N., elected, 148

Myers, C. S., elected, 126, 127

Myers-Ward, C. F., elected, 120

Nabarro, D. N., present as guest, 112; elected, 117

Needham, J., elected, 170

Neurological Society, Conjoint dinner to Ramón y Cajal, 109

Newton, Alfred, present as guest, 59, 60

Nicloux, B. (Paris and Strasburg), present as guest, 132

Noon, L., elected, 136

Norman, Conolly, present as guest, 63,65

North Berwick, dinner at, 146

North, W., elected, 53; demonstrations by, $64,66,70$

Nuttall, G. H. F., 124

O'Connor, J. M., elected, 172

O'Donoghue, C. H., elected, 149

Oliver, George, present as guest, 109; elected, 110

Oliver, Sir Thomas, elected, 106

Oliver, T. H., elected, 169

Oppenheimer, Mrs, see Tribe

Orr, John Boyd, elected, 157

Osborne, W. A., elected, 124.

Osler, Sir William, succeeds Burdon Sanderson at Oxford, 24; present as guest, 111, 136; elected, 143; biographical notice with portrait, 143; death reported to Society, 159

Overton, E., elected, 164

Owen, John, present as guest, 145

Oxford, first meeting at, 77; meeting of Society during meeting of British Association, 110

Page, F. J. M., present as guest, 47; elected, 48 ; demonstrations by, $59,64,65,70$; death reported to Society and resolution regarding adopted, 138

Paget, Sir George, influence in founding Prælectorship of Physiology in Trinity College, 3

Paget, Sir James, elected Honorary Member, 69 ; attends dinner meeting, 69; biographical notice, $\mathbf{7 0}$

Paget, Stephen, Life of Sir James Paget, 70; Honorary Secretary of Research Defence Society, 70

Pakes, W. C., elected, 120

Pantin, C. F. A., elected, 172

Parker, J., present as guest, 50; elected, 53

Parkes, A. S., elected, 172

Parsons, Sir John H., elected, 101, 102 
Passey, R. D., elected, 162, 163

Paton, Diarmid Noël, elected, 92; invitations from, 120, 121, 141; presides at meeting, 141

Patterson, S. W., elected, 151

Pavlov, I. P. (St Petersburg), working with Ludwig, 33; present as guest, 136; delivers Huxley Lecture, 136; gift to, 159; elected an Honorary Member, 140

Pavy, Frederick William, work of, 3; attends meeting founding the Society, 8; original member, 13; biography (with portrait), 28 ; signature, 44 ; communication by, 59; presentation to, 141, 142; last communication by, 146, 147; presides at meetings, 44, 51, 67, 111; death reported to Society and resolution of condolence with relatives adopted, 147

Payne, W. W., elected, 174, 175

Pearson, Karl, biography of Galton, 20

Pembrey, M. S., present as guest, 104; elected, 105; presides at meetings, 113, $116,147,151,159,172,176$; appointed. Treasurer, 173

Peskett, G. L., elected, 170

Peters, R. A., elected, 152

Pflüger, W. (Bonn), elected an Honorary Member, 127; death reported to Society, 144

Phear, A. D., present as guest, 112

Phillips, C. D. F., present as guest, 78, 79; elected, 82

Physiology, Development in Great Britain, 1; history of, by Michael Foster, 26; examinations in, at Royal College of Surgeons, 45, 102, 103; teaching of, 99, $101,102,119,130,147,149,151$; section of, at British Association meeting at Oxford, 110; at Glasgow, 167

Physiological Society, history of, 1 ; foundation of, 5-8; list of founders, 7 ; first rules, 8-12; original members of, 13; inaugural meeting. 15, members and guests present, 14, 15, 16; places of meeting, 41, 42; founded as dining club, 10,41 ; alterations in day of meeting, 47 , 49, 75; Minute Books: ioss and recovery of first Minute Book, 7, excisions in, 48, 83; dates of annual meetings, 48, 58, 79, 127; resolutions regarding scientific meetings, $49,50,54,58,73$; meetings at Richmond, 50, 51, 52; handwriting of minutes, 51; gratuities to waiters, 51 and 111; finances of, $50,53,91$; scientific communications, 55,93 ; list of members in $1880,56,57$; dinner to foreign physiologists attending International Medical Congress in 1881, 60; payment for dinner, 61; number of Honorary Members, 68, 69 ; provision for altering rules, 12, 69; number of ordinary members increased from forty to fifty, 48, made unlimited, 76 , results of this change, 76,80 ; Honorary Members elected, 13, 69, 104, 127, 156, 170,
178; scientific meetings, inauguration of, 54; Proceedings of, 56, 144, 146; subscription to Society, $9,74,75$; first meeting at Oxford, 77, at St Mary's Hospital, 88, at Edinburgh, 92, 95, 96, 125, at Conjoint Laboratories, 96, at Charing Cross Hospital Medical School, 97, at Guy's Hospital, 106, at St Bartholomew's, 115, at London Hospital, 116, at St Thomas's Hospital, 119, at Liverpool, 140, at Glasgow, 141, at Sheffield, 152, at the London School of Medicine for Women, 160, at Manchester, 167, at the National Institute for Medical Research, 167, at Cardiff, 177, at Bedford College, 177; question of appointing a President of the Society, 96; connexion with Royal Society, 96, 97; members present at dinner in February 1891, 98; recording of names of those present at scientific meetings, 100 ; revision of rules, 103, 105, $106,108,121,126,134,139,146,153$, 161, 165, 171, 174, 180; Minute Books during first fifty years, 104; appointment of a second Secretary, 112; representation on Catalogue Committee of Royal Society, 118; members present at dinner in January, 1898, also members of Committee and Officers, 120; special committee appointed to arrange business of International Physiological Congress at Cambridge, 121; limitation of time of communications, 120; dinner no longer a compulsory feature, 120; Society subscribes to Drechsel Memorial and to International Catalogue, 122; committee on Physiology in regard to Education, 130; resolution re Humane Slaughtering of Animals, 131; investment of funds, 132; proposed amalgamation with medical societies, 133 ; committee on proteid nomenclature appointed, 134, report, 135, 137; ladies dine with Society for first time, 136; International Catalogue, Mr Symes to undertake cataloguing, 138; reports of scientific papers to newspaper, 142; list of Officers and Committee for 1910 given, 143; contribution to expense of cataloguing physiological literature, 146; report from education committee re inclusion of Biology and especially Physiology in teaching of Public Health and Psychology, 147; deputation to Board of Education, report to Society, 149; committee on nomenclature of Central Nervous System appointed, 148, its report, 151; contribution to Lister Memorial, 150; question of admission of women to membership, 150; result of referendum, 152; composition of committee appointed to consider International Catalogue (publication of reports in English), 153, report of this committee, 154; Physiological Abstracts 
Physiological Society, history of (contd). started, 154, 155, grants from Royal Society and from American Societies, 155 , 159 , payments on account of, 155,156 , 158; removal of names of members of enemy nations moved but not adopted, 156 ; contribution to Board of Scientific Studies, 156, 158; Physiological Abstracts, publication of matter useful to the enemy, 157; joint meeting with Biochemical Society, 157; resolution deprecating the closing of the physiological laboratory of the University of London, 163; suspension of publication of Proceedings, 163, re-issued, 165, payments for, 165 ; arrangements with publishers for printing list of members, 165; Physiological Abstracts, arrangements for editing, 169 , discontinuance of publication considered, 171, J. Mellanby to be editor, 171; relation of Physiological Abstracts to American Biological Abstracts, 172, 173; Proceedings to be again available at the meetings, 174; celebration of 50th anniversary considered, 174 ; meeting at Leiden, 175, visit to Utrecht, 175, thanks of the Society to Dutch hosts, 176; laboratory of origin of papers may be mentioned in the Proceedings, 176; acquisition of Journal of Physiology by the Society, 177, 178; regulations for administering Journal, appointment of editors and trustees and arrangements for purchase, 179; celebration of 50th year from foundation of the Society, 180, 181; influence of the Society on physiology in Great Britain, 181

Pickering, J. W., elected, 106; re-elected,,166

Pierce, H. L., elected, 159

Plimmer, H. G., elected, 110

Plimmer, R. H. Aders, present as guest, 128; elected, 129; re-elected, 157

Ponder, Eric, elected, 165, 166

Poore, George Vivian, Inspector under the Act $39-40$ Vic. cap. 77,5

Poulton, E. B., elected, 77 ; resigns membership, 116

Poulton, E. P., elected, 142

Power, Sir d'Arcy, elected, 53

Power, Henry, attends preliminary meeting, 12; original member, 13; elected on first Committee, 45 ; presides at meetings, 50 , 66,84

Prælectorship of Physiology in Trinity College, Cambridge, foundation of, 3; appointment of Michael Foster, 4

President of the College of Physicians, Dublin, attends as guest, 48

Preyer, William (Jena), present at dinner to foreign physiologists in 1881, 60, 62

Priestley, J., elected, 48

Priestley, J. G., present as guest, 128; elected, 130, 131
Pringle, Harold, present as guest, 136; elected, 139; appointed to Trinity College, Dublin, 158

Pryde, John, elected, 168

Purser, J. M., attends dinner as guest, 60; elected, 80,81

Putnam, present as guest, 44

Pye, Walter, as visitor, 47; elected, 50, 51

Pye-Smith, Philip Henry, attends meeting founding the Society, 8; appointed member of Committee for drawing up Rules, 8; original member, 13; present at inaugural dinner (signature), 14; biography (with portrait), 29; elected on first Committee, 44; presides at meetings, $48,54,63,71,73,87,118,133$

Quain's Anatomy, edited by Sharpey, 18

Raiment, P. C., elected, 170

Ramsden, W., elected, 111

Ransom, F., elected, 144

Ransom, W. B., elected, 81

Raper, H. S., present as guest, 130; elected, 138

Ray, William, elected, 149

Reeves, H. G., elected, 172

Reeves, Sims, present as guest, 46

Reid, E. Waymouth, elected, 82

Research Defence Society, Stephen Paget Hon. Secretary of, 70; vote of $£ 100$ to, 139

Richardson, Benjamin W., original member, 13; death reported to Society, 116

Richardson, S. F. W., elected, 115

Richet, Charles (Paris), elected an Honorary Member, 156

Ringer, Sydney, present as guest, 55, 72; biographical notice with portrait, 55; demonstrations, 66, 70; elected, 77; signature, 93; presides at meetings, 94, 99; death reported to Society, 144

Ritchie, A. D., elected, 162

Ritchie, James, present as guest, 114, 115; elected, 130

Rivers, W. H. R., elected, 108

Roaf, H. E., elected, 132; appointed Honorary Secretary, 173

Roaf, Mrs, present as guest, 145

Roberts, Ffrangcon, elected, 151

Roberts, Sir William, elected, 94; biographical notice, 94; presides at meeting, 102; death reported to Society, 123

Robertson, J. McGregor, elected, 77

Robison, R., elected, 172

Rockwood, D. P., elected, 131

Rockwood, W., present as guest, 117

Rolleston, George, invited to become original member but declines, 13

Rolleston, Sir Humphry D., elected, 97

Romanes, George John, attends meeting founding the Society, 8; appointed one of the first Secretaries, 8; original mem- 
ber, 13; biography (with portrait), 35, 36; application to Scientific Grants Committee, 43; communication by, 55; appointed Treasurer, 63 ; communication by, 70; resigns Treasurership, 77

Rosenheim, O., elected, 131

Rothera, A. C. H., elected, 140

Roughton, F. J. W., elected, 167

Row, R., elected, 123, 124

Rowland, S. D., elected, 124; death reported to Society, 156

Rowlands, R. A., elected, 166

Roxburgh, present as guest, 60

Roxburgh, A. B., elected, 111

Roy, Charles Smart, present as guest, 52; biographical notice with portrait, 52; elected, 53; demonstrations by, 55, 58, $59,64,67,70$; presides at meeting, 95 ; resigns membership, 116

Royal Society, Scientific Grants, 40; recommendations by Society, 43 ; connexion with physiology, 97; Catalogue Committee, 117; Conjoint Board of Scientific Studies, 155; grants from, towards publication of Physiological Abstracts, 155, 157

Royal Society of Medicine, invitation from, to a discussion on "Life at High Altitudes," 167

Ruffer, Sir Armand, elected, 94; biographical notice, 94; communication from Law Officers re Vivisection, 112; death reported, 156

Rules of the Society, see Physiological Society

Russell, A. E , elected, 117

Russell, B. R. G., elected, 164

Russell, J. Risien, elected, 108

Russell, William, present as guest, 136

Rutherford, Sir Ernest, obituary notice of H. G. J. Moseley, 42

Rutherford, William, original member, 13; present at inaugural dinner (signature), 14; demonstration, 59; invitations from, $92,120,121$; death reported to Society, 123

Ryffel, J. H., elected, 140

Sainsbury, Harrington, present as guest, 70; elected, 94.

St Mary's Hospital Medical School, first meeting at, 88

St Thomas's Hospital, first meeting at, 119

Salamon, R. N., elected, 131

Salvin, Osbert, present as guest, 59, 60

Sanderson, Mrs (afterwards Lady Burdon Sanderson), letter of invitation to founders of Society, 5; letter from, acknowledging resolution re death of Sir John Burdon Sanderson, 134

Sanderson, Sir John Scott Burdon, succeeds Foster at University College, 3; pathological work, 4; superintendent of Brown Animal Sanatory Institution, 4; invites physiologists to his house to form
Society (facsimile of letter), 5; takes chair at meeting founding Society, 7; member of Committee for drawing up Rules, 8; original member, 13; present at inaugural dinner (signature), 14; biography (with portrait), 22-24; member of first Committee, 45; demonstrations by 59, 70; opens Hughes Bennett laboratory in Edinburgh, 125; presides at meetings, $43,45,54,70,77,79,84,85,86,90,99$, $104,106,107,110,111,114,117,122$, 130; death reported to Society, 134; resolution regarding him adopted and sent to Lady Sanderson, 134; her reply, 134

Savage, Sir George, present as guest, 82

Scarborough, Eleanor M., elected, 172

Schäfer(afterwards Sharpey-Schafer, which see)

Scharlieb (afterwards Shirley), H. J., present as guest, 128

Schiff, Maurice, testimonial to, 105

Schmiedeberg (Strasburg), elected an Honorary Member, 127

Schönland, attends as guest, 86

Schryver, S. B., present as guest, 128; elected, 128

Schuster, E. H. J., sub-editor of Physiological Abstracts, 169

Scott, Dr and Mrs (New York), present as guests, 176

Scott, D. H., present as guest, 63,67

Scott, F. H., elected, 137

Scott, J. M. Duncan, elected, 170

Scott, Munro, present as guest, 116

Scott, S. G., elected, 141; death reported to Society, 157

Secker, T., elected, 172

Segall, H. N., elected, 177

Semon, Sir Felix, present as guest, 83

Semon, Richard, present as guest, 107

Seward, A. C., present as guest, 128

Shanks, W. F., elected, 168

Sharpey, William, appointed to Chair of General Anatomy and Physiology in University College, 1; introduces Michael Foster as Professor of Practical Physiology, 2; attends meeting founding the Society, 7; Honorary Member, 13; biography (with portrait), 17-19; presides at meeting, 44; signature, 44 ; resolution concerning death of, 54

Sharpey-Schafer, Sir Edward, assistant to Burdon Sanderson, 4; attends meeting founding Society and seconds resolution appointing Officers and Committee for drawing up rules, 8; original member, 13 ; present at inaugural dinner (signature), 14; application to Scientific Grants Committee, 43; member of first Committee, 45; demonstrations, 55, 64, 65, $70,71,150$; presides at meetings, 46,75 , $78,83,88,95,114,125,129,135,146,158$, 176; first president of Physiology 
Sharpey-Schafer, Sir Edward (contd). Section of British Association, 110; takes chair at dinner to Michael Foster and Burdon Sanderson, 27, to Ramón y Cajal, 109, to Engelmann, 112, to Sherrington, 81 , to foreign physiologists attending International Medical Congress (1913), 150; invitation from, 158; presides at Eleventh International Physiological Congress in Edinburgh (1923), 170; asked to write report on the foundation of the Society,174

Shaw, W. V., elected, 130

Shaxby, J. H., elected, 174.

Sheffield, first meeting at, 152

Shennan, T., present as guest, 136

Sherrington, Sir Charles, finds first Minute Book, 7; present as guest, 72, 75; elected, 80 ; dinner to celebrate his election as President of the Royal Society, 81; elected Honorary Secretary, 92; resigns on appointment to Chair of Physiology at Liverpool, 113; presentation to, 113; invites Society to Liverpool, 140; presides at meetings, 140, 144, 152, 154, 159, 163, $166,169,172$; appointed to Oxford, 152; congratulations of Society on his being elected President of the Royal Society, 161; dinner to, 161, 165; congratulations of the Society on Grand Cross of the British Empire, 166; congratulations to, on receiving Order of Merit, 172; appointed Chairman of Editorial Board of Journal, 179

Sherrington, Mrs, presentation to, 113

Shirley, see Scharlieb

Shore, L. E., present as guest, 86; elected, 87,88

Shore, T. W., present as guest, 88 ; elected, 92

Sikes, A. W., elected, 123; re-elected, 139

Simpson, present as guest, 45

Simpson, Sutherland, present as guest, 125 ; elected, 126; death of, reported to Society and vote of condolence with relatives passed, 179, 180

Skelton, Ruth F., elected, 154

Slater, W. K., elected, 169

Smart, W. A. M., elected, 162

Smith, Sir Frederick, elected, 110

Smith, F. C., elected, 172

Smith, G. Elliot, present as guest, 116, 145; elected, 160

Smith, J. Lorrain, elected, 98

Smith, K. Shirley, elected, 174

Smith, Meade, attends as guest, 51

Smith, W., elected, 170

Smith, W. G., elected, 127

Smith-Jerome, W. J., elected, 124

Société de Biologie, letter to regarding death of Claude Bernard, 47; reply, 49; presentation of Proceedings to, 86; foundation of, 181

Sowton, Miss S. C. M., present as guest, 136, 145

de Souza, D. H., elected, 139
Spearman, C., elected, 141

Spence, J. C., elected, 172

Spencer, W. G., present as guest, 90, elected 97,98

Sprengel, H. J. F., present as guest, 69

Spriggs, E. I., elected, 123

Squire, J. E., present as guest, 115, 116

Stafford, W., elected, 117

Starling, Ernest H., present as guest, 90, 93; biographical notice (with portrait), 90 ; elected, 94; elected Secretary, 113; presides at meetings, 127, 129, 134, 138, 139, $141,144,147,150,151,153,163,166$, $168,169,179$; serious illness of, votes of sympathy from Society and International Congress in Paris, 161; death of, and obituary notice by C. J. Martin, 90 (footnote)

Stevenson, Sir Thomas, elected, 111; presides at meeting, 129 ; resigns membership, 137

Stewart, Charles, attends as guest, 50

Stewart, George Neil, present as guest, 93; elected, 94

Stewart, Sir Thomas Grainger, elected, 97

Stiles, Sir Harold, present as guest, 125

Stirling, Sir E. C., elected, 101, 102

Stirling, William, elected, 44, 45, 58; presides at meeting, 105

Stockholm, Twelfth International Physiological Congress (1926) at, 174

Stockman, R., elected, 92

Stokes, Adrian, elected, 174; biographical sketch (with portrait), 174.

Stopford, J. S. B., elected, 164

Stuart, Sir Thomas Anderson, attends dinner as guest, 60,61 ; present as member, 119; death reported to Society, 162

Styles, Wallis, sub-editor of Physiological Abstracts, 169

Surveyor, N. F., elected, 126

Symes, W. L., present as guest, 79, 93; elected, 97; to undertake cataloguing of physiological papers, 138; vote of thanks for assisting Treasurer with accounts, 167

Tait, John, present as guest, 129, 136 elected, 136; appointed to McGill University, 158

Tallerman, K. H., elected, 174

Terry, Constance Leetham, elected, 154

Thane, Sir George, Chief Inspector under the Act 39-40 Vic. cap. 77, 5; present as guest, 64; elected, 69

Thacker, W. R. (? C. R. A.), elected, 154

Thomas, Sir W. J., invited to attend meeting at Cardiff, 177

Thompson, Sir W. H., elected, 108; death reported to Society, 157

Thompson, Mrs, present as guest, 136

Thompson (New York), present as guest, 90

Thomson, Alexis, present as guest, 125

Thomson, Allen, present as guest, 46; elected, 48; elected Honorary Member, 69 
Thomson, Arthur, present as guest, 86, 90

Thomson, John, present as guest, 125

Tidy, H. L., elected, 149, 150

Tigerstedt, Robert (Helsingfors), present as guest, 148

Toms, present as guest, 80

Tooth, Howard, elected, 98

Trevan, J. W., elected, 155

Tribe, Enid M. (Mrs Oppenheimer), elected, 154

Trotter, Coutts, influence of, in foundation of Prælectorship of Physiology in Trinity College, 3 ; present as guest, 52, 80

Tschirjew, present as guest, 50

Tubby, A. H., elected, 101

Tuckett, Ivor Lloyd, elected, 115

Tuke, Sir John Batty, elected, 97

Tunnicliffe, F. W., elected, 113, 114.

Turner, Logan, present as guest, 125

Turner, Sir William, 3; present as guest, 125,135

Underhill, S. W. F., elected, 162

Underhill, Vice-President of Magdalen College, present as guest, 86

University of London, invitation from, 127

Utrecht, visit to, by members of the Society, 175

Verney, E. B., elected, 166

Vernon, H. M., elected, 117

Vignal, present as guest, 67

Vincent, Swale, elected, 117; re-elected, 160

Vines, H. W. C., elected, 164.

Vines, Sydney Howard, present as guest, 40,41

Vivisection, First Royal Commission on, 4; Act of Parliament 38-39 Vic. cap. 77, 5; agitation against vivisection, 4 ; evidence of Klein, 32; demonstration certificates, 40 ; complaint of a member, 44 ; report of committee on working of Act, 45; com. mittee re administration of Act for therapeutic experiments, 46,47 ; methods of counteracting agitation, 46, 47; committee on policy, 60 ; report of the committee, 62; another committee on the working of the Act, 63 ; report of this committee, 64, 65; prosecution of Dr Ferrier, 67; complaint as to withholding certificates, 75; methods of combating antivivisection agitation, 79; communication from Law Officers of the Crown, 112; resolution re medical schools where experimental work is prohibited, 114; counsel's opinion to be obtained on libel, 118; second Royal Commission on, 135; committee appointed, 136; its report, 137; lectures on vivisection, 139; vote of $£ 100$ to Research Defence Society, 139; Report of Royal Commission to be referred to Committee, 147, 148

Vogt, Oskar (Berlin), and Frau Vogt, present as guests, 145
Waldstein, present as guest at dinner to foreign physiologists, 1881, 60

Walker, Charles E., elected, 163, 164

Walker, E., elected, 174

Walker, E. W. A., elected, 126

Walker, May L., elected, 160

Wallace, Sir Cuthbert S., elected, 160

Waller, Augustus, 53

Waller, Augustus Désiré, elected, 53; biographical notice with portrait, 53; demonstrations by, 53, 64, 70; presides at meetings, 88, 93, 104, 107, 111, 115, 119,122 , 133, 134; takes over Treasurership, 114; death of, reported to Society and vote of sympathy with Mrs Waller passed, 166

Waller, Mrs, 53

Waller, J. C., elected, 174

Waller, W. W., elected, 162, 163

Wallis, Mackenzie, elected, 146

Walshe, F. M. R., elected, 164

Walton, present as guest, 70

Warburg, E. J., elected, 172

Wardlaw, H. S. H., elected, 172

Warner, E. C., elected, 168

Warrington, Dr, present as guest, 145

Warrington, W. B., elected, 132

Washbourn, J. W., elected, 101

Wastl, Helena, elected, 174

Waters, W. Horscraft, present as guest, 58, 59,60 ; elected, 69 ; death of, 84

Watney, Herbert, present as guest, 60, 61

Watson, A., elected, 177

Watson, Chalmers, present as guest, 125; elected, 133

Watson, Mrs Chalmers, present as guest, 136

Watson, E. M., elected, 168

Watt, J. M., elected, 164

de Watteville, A., present as guest, 63, 64; elected, 77; resigns membership, 116

Weldon, W. F. R., present as guest, 130

Welsh, D. A., present as guest, 125; elected, 144

White, C. F., present as guest, 125

White, Powell, elected, 128

Whitehead, Raymond, elected, 174

Whitfield, E. H., elected, 94

Whiting, A. J., elected, 110

Whitley, E., elected, 133

Widdicombe, J. H., elected, 126

Wiener biologische Gesellschaft, letter from President of re death of Langley, 178

Williams, Dr (New York), present as guest, 146

Williams, E. H. G., elected, 164

Williams, Sir J. Dawson, elected, 94, 95

Williams, O. T., elected, 140

Wilmer, E. N., elected, 174

Wilson, present as guest, 86

Wilson, H. C., elected, 177

Wilson, S. A. Kinnear, elected, 160, 161

Wilson, W. H., elected, 117

Wiltshire, Miss M. O. P., elected, 169 
Winfield, George, elected, 154

Wingfield, H. E., elected, 92

Winter, L. B., elected, 170

Winton, F. R., elected, 174

Wishart, G. M., elected, 165

Wolf, C. G. L., elected, 149, 150

Wolfenden, R. Norris, elected, 82

Wolsely, present as guest, 49

Wood, G. Cartwright, elected, 101

Woodhead, Sir German Sims, elected, 87, 88; presides at meetings, $96,100,105$, 108; death reported to Society, 165

Woodworth, R. S., elected, 127

Wooldridge, Leonard Charles, present as guest, 67; elected, 69; biographical notice (with portrait), 69; death of, reported to Society, and resolution of sympathy with Mrs Wooldridge adopted, 90

Woollard, H. H., elected, 172

Woolley, V. J., elected, 126; presides at meeting, 173

Wright, Sir Almroth E., present as guest, 86, 87; elected, 101
Wright, G. P., elected, 177

Wright, Samson, elected, 168

Yeo, Gerald Francis, attends meeting founding the Society, 8; first Secretary, 8; original member, 13 ; present at inaugural dinner (signature), 14; biography (with portrait), 32, 33; application to Scientific Grants Committee, 43; demonstrations by, 66,71 ; resignation of Secretaryship, 92; testimonial to, 95; attends dinner and health proposed, 107; death reported to Society and resolution of sympathy with Mrs Yeo adopted, 141

Young, Robert Arthur, present as guest, 52

Young, W. J., elected, 138

Yorke, Warrington, present as guest, 145

Yule, C., original member, 13

Ziehen, Theodor (Jena), present as guest, 110

Zilva, S. S., elected, 169

Zwaardemaker (Utrecht), letter of thanks to, 176

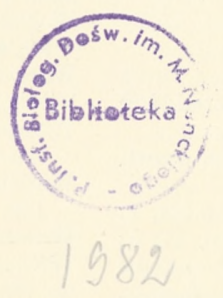


CAMBRIDGE : PRINTED BY

W. LEWIS, M.A.

AT THE UNIVERSITY PRESS 
rcin.org.pl 
rcin.org.pl 
1982 